DANIEL VIEIRA MINEGATTI DE OLIVEIRA

\title{
AVALIAÇÃO DA REMOÇÃO DE NITROGÊNIO VIA NITRIFICAÇÃO E DESNITRIFICAÇÃO SIMULTÂNEA EM UM REATOR BIOLÓGICO COM LEITO MÓVEL (IFAS)
}

São Paulo 2015 
DANIEL VIEIRA MINEGATTI DE OLIVEIRA

\section{AVALIAÇÃO DA REMOÇÃO DE NITROGÊNIO VIA NITRIFICAÇÃO E DESNITRIFICAÇÃO SIMULTÂNEA EM UM REATOR BIOLÓGICO COM LEITO MÓVEL (IFAS)}

Tese apresentada à Escola Politécnica da Universidade de São Paulo para obtenção do título de Doutor em Engenharia Civil.

São Paulo 


\section{AVALIAÇÃO DA REMOÇÃO DE NITROGÊNIO VIA NITRIFICAÇÃO E DESNITRIFICAÇÃO SIMULTÂNEA EM UM REATOR BIOLÓGICO COM LEITO MÓVEL (IFAS)}

Tese apresentada à Escola Politécnica da Universidade de São Paulo para obtenção do título de Doutor em Engenharia Civil.

Área de Concentração: Engenharia Hidráulica e Sanitária

Orientador: Prof. Dr. Roque Passos Piveli

São Paulo 
Este exemplar foi revisado e alterado em relação à versão original, sob responsabilidade única do autor e com a anuência de seu orientador.

São Paulo,07 de fevereiro de 2016.

Assinatura do autor

Assinatura do orientador

Catalogação-na-publicação

MINEGATTI, DANIEL

AVALIAÇÃO DA REMOÇÃO DE NITROGÊNIO VIA NITRIFICAÇÃO E DESNITRIFICAÇÃO SIMULTÂNEA EM UM REATOR BIOLÓGICO COM LEITO MÓVEL (IFAS) / D. MINEGATTI, R. PIVELI, I. VOLSCHAN -- versão corr. -- São Paulo, 2015

$117 \mathrm{p}$.

Tese (Doutorado) - Escola Politécnica da Universidade de São Paulo. Departamento de Engenharia de Hidráulica e Ambiental.

1.REMOÇÃO DE NITROGÊNIO 2.NITRIFICAÇÃO E DESNITRIFICAÇÃO SIMULTÂNEA 3.TECNOLOGIA IFAS I.Universidade de São Paulo. Escola Politécnica. Departamento de Engenharia de Hidráulica e Ambiental II.t. III.PIVELI, ROQUE IV.VOLSCHAN, ISAAC 
MINEGATTI, D. V. O. Título: AVALIAÇÃO DA REMOÇÃO DE NITROGÊNIO VIA NITRIFICAÇÃO E DESNITRIFICAÇÃO SIMULTÂNEA EM UM REATOR BIOLÓGICO COM LEITO MÓVEL (IFAS).São Paulo. 2015. 117p. (Doutorado) Escola Politécnica, Universidade de São Paulo, São Paulo, 2015. 
DEDICATÓRIA

Aos meus sobrinhos, em especial, aos afilhados Sophia e Nicolas, que essa conquista lhes inspire. Pois, como meu saudoso pai sempre dizia, a única coisa que ninguém pode nos tirar na vida é o conhecimento, anossa bagagem. 


\section{AGRADECIMENTOS}

A Deus, meu fiel companheiro, que em todos momentos me deuforça, paciência e coragem para seguir em frente...como sempre digo: EU e DEUS!!!

Ao professor Roque por me "aguentar", por sustentartodas as adversidadespassadas nesses 5longos anos...Meu eterno obrigado!

Aos professores Jordão e Pedro Além. Hoje tenho a consciência que deveria ter "explorado" mais de vocês. Mas, de qualquer forma, muito obrigado pelo enorme conhecimento transmitido.

Em especial ao professor Isaac, apesar de dizer que foi um "orientador financiador", foi mais que um orientador, foi, por vezes, um amigo, um companeiro, um pai que quer ver o crescimento de um filho; dando é claro, uns bons puxões de orelha. Obrigado...Foi demais!!!

A todos do LEMA, DRHIMA CESA, Darlise, Cida, Eder, Maria Cristina, Paulinho, Marcelo, Diego, Janaína, Francisco, Natália, Juliana, Gabriel, Ronilda, Tania,Jéssica...sem vocês nada disso seria possível.

A turma da USP, principalmente ao Rodrigo, Fabio e a caríssima Wandréa...valeu!

Ao prof. Jaime da FIOCRUZ e ao quase Dr. Renato, pela disponibilização e ajuda em relação ao equipamento de medição de $\mathrm{N}_{2} \mathrm{O}$.

A "Dra" Maria Teresa, por me ajudar a compreender um pouquinhomais o sentido da vida. Palavras antes esquecidas, como: Equilíbrio, Naturalidade, Sinceridade, Discernimento, Comprometimento, Autenticidade, Plenitude; enfim, AMOROSIDADE, hoje fazem parte do meu vocabulário, da minha vida! Muito obrigado por tudo!!

Aos amigos e colegas, espalhados nesse mundão de meu Deus, que, cada um da sua maneira, contribuiu para essa conquista. Especialmente a minha "parceira" Laila, valeu pelo apoio nesses últimos meses.

Por fim, e mais importante, a minha FAMílIA, essa sim espalhada pelo mundo, nos EUA, em Minas, na Bahia, em Santa Catarina... Atualmente, mais do que nunca, vejo o quão 
importante cada um de vocês é para mim. Descobri, profundamente, o que é saudade...Porque nunca desejei tanto um abraço/aconchego de vocês. AMO-LHES!!! 


\section{RESUMO}

O fenômeno conhecido como Nitrificação e Desnitrificação Simultânea (SND) significa que em um mesmo reator ocorre simultaneamente a nitrificação e a desnitrificação, sob condições de operações idênticas, podendo ser justificada principalmente pela teoria de microambiente no floco ou biofilme. Assim, em um único reator, sob condições controladas de oxigênio dissolvido (OD) e elevados tempos de residênciacelular épossível que ocorra a nitrificação e a criação de zonas anóxicas no interior dos flocos ou biofilme para a ocorrência da desnitrificação. Neste sentido, a tecnologia MBBR/IFAStem como característicaelevado tempo de residência celular do biofilme formado nos meios suporte presentes no reator. Deste modo, neste estudo avaliou-se a remoção de nitrogênio via SND em um sistema IFAS quando submetido a diferentes concentrações de OD e Tempo de DetençãoHidraulica de 5,5 e 11 horas, tratando efluente sanitário e efluente sintético. Os resultados experimentais demonstraram que pode ser possível desenvolver efetiva SND com concentrações de OD média de $1,0 \mathrm{mg} \cdot \mathrm{L}^{-1}$ e $1,5 \mathrm{mg} \cdot \mathrm{L}^{-1}$. Sendo que, foram obtidas eficiência média de remoção de NTde cerca de $68 \%$ e concentrações médias efluente de $\mathrm{N}-\mathrm{NH}_{4}$ de aproximadamente $5,0 \mathrm{mg} \mathrm{L}^{-1}$, de $\mathrm{N}-\mathrm{NO}_{3}$ inferiores a $4,5 \mathrm{mg} \mathrm{L}^{-1}$ e de $\mathrm{N}-\mathrm{NO}_{2}$ em torno de $0,1 \mathrm{mg} \mathrm{L}^{-1}$, e com eficiência média de remoção DQO solúvel acima de $90 \%$, quando empregado efluente sintético. Ademais, por meio da avaliação da emissão de Óxido Nitroso $\left(\mathrm{N}_{2} \mathrm{O}\right)$, foi possível comprovar que a desnitrificação ocorreu de forma efetiva. 


\begin{abstract}
The phenomenon known as Simultaneous Nitrification and Denitrification (SND) means that in the same reactor simultaneously occurring nitrification and denitrification under identical operations conditions, and can be mainly explained by the microenvironment theory inside the floc or biofilm. Therefore, in a single reactor under controlled conditions of dissolved oxygen (DO) and high Solids Retention Time (SRT) it is possible that the nitrification happens and the creation of anoxic zones within the flocsor biofilm to the occurrence of the denitrification. In this sense, the MBBR/IFAS technology is characterized by high SRT of the biofilm formed on the carriers present in the reactor. Thereby,this work evaluated the nitrogen removal through SND in a IFAS system when submitted to different DOconcentrations and Hydraulic Retention Time of 5.5 hours and 11.0 hours, treating domestic and synthetic effluents. The experimental results showed that it may be possible to develop effective SND withaverage concentrations of DO of 1.0 $\mathrm{mg} \mathrm{L}^{-1}$ and $1.5 \mathrm{mg} \mathrm{L}^{-1}$. It was obtained a TN average removal efficiency about $68 \%$, and an average effluent concentration of $\mathrm{NH}_{4}-\mathrm{N}$ of approximately $5.0 \mathrm{mg} \mathrm{L}^{-1}$, of $\mathrm{NO}_{3}-\mathrm{N}$ less than $4.5 \mathrm{mg} \mathrm{L}^{-1}$ and of $\mathrm{NO}_{2}-\mathrm{N}$ around $0.1 \mathrm{mg} \mathrm{L}^{-1}$, and an average CODsoluble removal efficiency above $90 \%$, employing synthetic effluent. Furthermore, by evaluating the Nitrous Oxide $\left(\mathrm{N}_{2} \mathrm{O}\right)$ emission, it was possible to prove that the denitrification occurred effectively.
\end{abstract}




\section{LISTA DE FIGURAS}

Figura 3.1: Princípio do funcionamento da tecnologia MBBR/IFAS

Figura 3.2: Representação esquemática dos gradientes de OD e DBO no floco 9

Figura 3.3: Presença de biomassa em suspensão 9

Figura 3.4: Representação esquemática de uma seção de biofilme 10

Figura 3.5: Biomassa aderida aos meios suporte

Figura 3.6: Relação entre taxa de nitrificação e idade do lodo

Figura 3.7: Relação entre a carga de nitrogênio amoniacal e a taxa de nitrificação no experimento conduzido por RUSTENet al. (1995).....

Figura 3.8: Relação entre taxa de nitrificação e concentração de oxigênio dissolvido em sistema com MBBR em escala piloto (RUSTENet al., 1995)

Figura 3.9: Relação entre a concentração de $\mathrm{OD}$ e a $\operatorname{COS}$ com taxa de remoção de $\mathrm{N}-\mathrm{NH}_{4}$ (HEM el al. 1994) 15

Figura 3.10: Variação teórica versus variação experimental da alcalinidade para diferentes sistemas de lodo ativado.

Figura 4.1: Cronologia do Experimento

Figura 4.2: Vista geral do CESA/UFRJ

Figura 4.3: Tratamento preliminar

Figura 4.4: Vista do aparato experimental (Reator IFAS 1)....... 38

Figura 4.5: Sistema de peneira..... 38

Figura 4.6: Decantador secundário - IFAS 1

Figura 4.7: Reatores IFAS 2 e IFAS 3 
Figura 4.8: Controlador/Timer da bomba de reciclo de lodo 40

Figura 4.9: Mangueira difusora de bolha média

Figura 4.10: Compressor de ar - Reatores IFAS 2 e IFAS 3

Figura 4.11: Tela do computador indicando OD médio

Figura 4.12: Meio suporte empregado - Empresa Aqwise

Figura 4.13: Aplicação da metodologia para quantificação da biomassa aderida ao meio suporte. 50

Figura 4.14: Equipamento Los Gatos 51

Figura 4.15: Detalhe da tela do equipamento Los Gatos 51

Figura 5.1: Eficiência de remoção de $\mathrm{DQO}, \mathrm{DQO}_{\text {sol }}$ e SST 53

Figura 5.2: Concentração efluente e eficiência de remoção de SST. 54

Figura 5.3: COS versus eficiência de DQO 55

Figura 5.4: Concentrações afluente e efluente de $\mathrm{N}-\mathrm{NH}_{4}$ 55

Figura 5.5: Concentrações afluente e efluente de NTK 56

Figura 5.6: Concentração de OD ao longo do período de monitoramento de $\mathrm{N}_{2} \mathrm{O}$ 58

Figura 5.7: Eficiência de remoção de DQO, DQOsol e SST 59

Figura 5.8: Eficiência de DQO versus COS aplicada 60

Figura 5.9: Eficiência de remoção de $\mathrm{N}-\mathrm{NH}_{4}$ e NTK. 60

Figura 5.10: Eficiência de remoção de $\mathrm{N}-\mathrm{NH}_{4}$ versus $\mathrm{COS}$ aplicada ..... 61

Figura 5.11: Emissão de $\mathrm{N}_{2} \mathrm{O}$ ao longo do período de monitoramento - Fase 1.2...... 62

Figura 5.12: Concentração de $\mathrm{OD}$ ao longo do período de monitoramento de $\mathrm{N}_{2} \mathrm{O}$ 64 
Figura 5.13: Eficiência de remoção de DQO, DQOsol e DBO - IFAS 1, 2 e 3

Figura 5.14: DQO afluente e efluente e eficiência DQO - IFAS 1 68

Figura 5.15: DQO afluente e efluente e eficiência DQO - IFAS 2 68

Figura 5.16: DQO afluente e efluente e eficiência DQO - IFAS 3 68

Figura 5.17: Eficiência de DQO versus COS aplicada - IFAS 1. 69

Figura 5.18: Eficiência de DQO versus COS aplicada - IFAS 2. 69

Figura 5.19: Eficiência de DQO versus COS aplicada - IFAS 3. 70

Figura 5.20: $\mathrm{N}-\mathrm{NH}_{4}$ afluente e efluente e eficiência $\mathrm{N}-\mathrm{NH}_{4}-$ IFAS 1. 70

Figura 5.21: $\mathrm{N}-\mathrm{NH}_{4}$ afluente e efluente e eficiência $\mathrm{N}-\mathrm{NH}_{4}-$ IFAS 2 . .71

Figura 5.22: $\mathrm{N}-\mathrm{NH}_{4}$ afluente e efluente e eficiência $\mathrm{N}-\mathrm{NH}_{4}-$ IFAS 3. .71

Figura 5.23: Eficiência de remoção de $\mathrm{N}-\mathrm{NH}_{4}$ versus COS aplicada - IFAS 1. 72

Figura 5.24: Eficiência de remoção de $\mathrm{N}-\mathrm{NH}_{4}$ versus COS aplicada - IFAS 2 . 72

Figura 5.25: Eficiência de remoção de $\mathrm{N}-\mathrm{NH}_{4}$ versus COS aplicada - IFAS 3 ........ 72

Figura 5.26: Tela do computador indicando OD médio no IFAS 2 - Fase $2.1 \ldots \ldots \ldots \ldots \ldots \ldots \ldots . . . . . . . . .75$

Figura 5.27: Tela do computador indicando OD médio no IFAS 3 - Fase 2.1.................... 75

Figura 5.28: DQO afluente e efluente e eficiência DQO - IFAS 1 .77

Figura 5.29: $\mathrm{N}-\mathrm{NH}_{4}$ afluente e efluente e eficiência $\mathrm{N}-\mathrm{NH}_{4}-$ IFAS 1. .78

Figura 5.30: Eficiência de remoção de DQO versus COS aplicada - IFAS 1 78

Figura 5.31: Eficiência de remoção de $\mathrm{N}-\mathrm{NH}_{4}$ versus COS aplicada - IFAS 1. 79

Figura 5.32: $\mathrm{N}-\mathrm{NH}_{4}$ afluente e efluente e eficiência $\mathrm{N}-\mathrm{NH}_{4}$ - IFAS 2 (antes da repartida) . 80

Figura 5.33: $\mathrm{N}-\mathrm{NH}_{4}$ afluente e efluente e eficiência $\mathrm{N}-\mathrm{NH}_{4}$ - IFAS 3 (antes da repartida) . 81 
Figura 5.34: $\mathrm{DQO}_{\text {sol }}$ afluente e efluente e eficiência $\mathrm{DQO}_{\text {sol }}$ - IFAS 2 (antes da repartida) 81

Figura 5.35: $\mathrm{DQO}_{\text {sol }}$ afluente e efluente e eficiência $\mathrm{DQO}_{\text {sol }}-$ IFAS 3 (antes da repartida) 82

Figura 5.36: $\mathrm{DQO}_{\text {sol }}$ afluente e efluente - IFAS 2 (após a repartida) .83

Figura 5.37: Eficiência de remoção de DQOsol - IFAS 3 (após a repartida) .84

Figura 5.38: Eficiência de DQO versus COS aplicada para IFAS 2 (após a repartida)..... 84

Figura 5.39: Eficiência de DQOsol versus COS aplicada para IFAS 3 (após a repartida) ..... 85

Figura 5.40: Eficiência de $\mathrm{N}-\mathrm{NH}_{4}$ versus COS aplicada para IFAS 2 (após a repartida) 85

Figura 5.41: Eficiência de $\mathrm{N}-\mathrm{NH}_{4}$ versus COS aplicada para IFAS 3 (após a repartida) 86

Figura 5.42: Concentração média afluente e efluente dos compostos nitrogenados IFAS 2 (após a repartida) 86

Figura 5.43: Concentração média afluente e efluente dos compostos nitrogenados IFAS 3 (após a repartida)

Figura 5.44: $\mathrm{DQO}_{\text {sol }}$ afluente e efluente e eficiência $\mathrm{DQO}_{\text {sol }}$ - IFAS 2 (após a repartida).... 87

Figura 5.45: $\mathrm{DQO}_{\text {sol }}$ afluente e efluente e eficiência $\mathrm{DQO}_{\text {sol }}$ - IFAS 3 (após a repartida).... 88

Figura 5.46: $\mathrm{N}-\mathrm{NH}_{4}$ afluente e efluente e eficiência $\mathrm{N}-\mathrm{NH}_{4}$ - IFAS 2 (após a repartida)..... 88

Figura 5.47: $\mathrm{N}-\mathrm{NH}_{4}$ afluente e efluente e eficiência $\mathrm{N}-\mathrm{NH}_{4}$ - IFAS 3 (após a repartida)..... 88

Figura 5.48: Eficiência $\mathrm{N}-\mathrm{NH}_{4}$ versus pH efluente - IFAS 2 (após a repartida). 90

Figura 5.49: Eficiência $\mathrm{N}-\mathrm{NH}_{4}$ versus pH efluente - IFAS 3 (após a repartida).................... 90

Figura 5.50: Eficiência $\mathrm{N}-\mathrm{NH}_{4}$ versus relação C/NTK - IFAS 2 (após a repartida). 91

Figura 5.51: Eficiência $\mathrm{N}-\mathrm{NH}_{4}$ versus relação C/NTK - IFAS 3 (após a repartida). 91

Figura 5.52: Taxa de Nitrificação versus Carga Superficial de $\mathrm{N}-\mathrm{NH}_{4}$ - IFAS 2 (após a repartida) 92 
Figura 5.53: Taxa de Nitrificação versus Carga Superficial de $\mathrm{N}-\mathrm{NH}_{4}$ - IFAS 3 (após a repartida)

Figura 5.54: Emissão de $\mathrm{N}_{2} \mathrm{O}$ ao longo do período de monitoramento - IFAS 2 (após repartida)

Figura 5.55: Emissão de $\mathrm{N}_{2} \mathrm{O}$ ao longo do período de monitoramento - IFAS 3 (após repartida) 94

Figura 5.56: Taxa de Nitrificação versus Concentracao de OD 100

Figura 5.57: Emissão de $\mathrm{N}_{2} \mathrm{O}$ ao longo do período de monitoramento - Fase 1.1. 101

Figura 5.58: Emissão de $\mathrm{N}_{2} \mathrm{O}$ ao longo do período de monitoramento - Adaptação Fase 1.2 102

Figura 5.59: Emissão de $\mathrm{N}_{2} \mathrm{O}$ ao longo do período de monitoramento - Fase 1.2 ........... 102

Figura 5.60: Emissão de $\mathrm{N}_{2} \mathrm{O}$ ao longo do período de monitoramento da Fase 2.2 - IFAS 2 (após repartida) 102

Figura 5.61: Emissão de $\mathrm{N}_{2} \mathrm{O}$ ao longo do período de monitoramento na Fase 2.2 - IFAS 3 (após repartida) 103 


\section{LISTA DE TABELAS}

Tabela 4.1: Características dos reatores IFAS 2 e IFAS 3.

Tabela 4.2: Condições operacionais Etapa 1

Tabela 4.3: Condições operacionais Etapa 2

Tabela 4.4: Característica do efluente sintético

Tabela 4.5: Característica da solução de micronutrientes

Tabela 4.6: Pontos de amostragem

Tabela 4.7: Parâmetros analisados com respectivos métodos adotados

Tabela 5.1: Resultados do monitoramento do Reator IFAS 1 - Fase $1.1\left(\mathrm{mg} \mathrm{L}^{-1}\right)$ 53

Tabela 5.2: Resultados de DBA ( $\mathrm{mg} \mathrm{L}^{-1}$ ) e SSV expresso em $\mathrm{g} \mathrm{m}^{-2}$ ao longo da Fase $1.1 \ldots . .54$

Tabela 5.3: Resultados do monitoramento do Reator IFAS 1 - FASE $1.2\left(\mathrm{mg} \mathrm{L}^{-1}\right)$ 59

Tabela 5.4: Resultados de DBA ( $\mathrm{mg} \mathrm{L}^{-1}$ ) e SSV expresso em $\mathrm{g} \mathrm{m}^{-2}$ ao longo da Fase $1.2 \ldots . .63$

Tabela 5.5: Resultados do monitoramento do Reator IFAS 1 - Fase 2.1 (mg L ${ }^{-1}$ ) .65

Tabela 5.6: Resultados do monitoramento do Reator IFAS 2 - Fase $2.1\left(\mathrm{mg} \mathrm{L}^{-1}\right)$ 65

Tabela 5.7: Resultados do monitoramento do Reator IFAS 3 - Fase 2.1 (mg L ${ }^{-1}$ ) 66

Tabela 5.8: Resultados dos principais parâmetros operacionais e de controle - Fase 2.1.73

Tabela 5.9: Resultados do monitoramento do Reator IFAS 1 - Fase $2.2\left(\mathrm{mg} \mathrm{L}^{-1}\right)$ .76

Tabela 5.10: Resultados do monitoramento do Reator IFAS 2 - Fase 2.2 (mg L ${ }^{-1}$ ) (antes da repartida) 79

Tabela 5.11: Resultados do monitoramento do Reator IFAS 3 - Fase $2.2\left(\mathrm{mg} \mathrm{L}^{-1}\right.$ ) (antes da nova partida) .79 
Tabela 5.12: Resultados do monitoramento do Reator IFAS 2 - Fase 2.2 ( $\mathrm{mg} \mathrm{L}^{-1}$ ) (após a repartida)

Tabela 5.13: Resultados do monitoramento do Reator IFAS 3 - Fase $2.2\left(\mathrm{mg} \mathrm{L}^{-1}\right.$ ) (após a repartida)

Tabela 5.14: Resultados dos principais parâmetros operacionais e de controle - Fase 2.2 Reatores IFAS 1 e IFAS 2 e IFAS 3 (após a repartida)....

Tabela 5.15: Variação da alcalinidade teórica e observada durante a Fase 2.2 - Reatores IFAS 2 e 3 (após a repartida) 96

Tabela 5.16: Eficiências médias de remoção dos principais parâmetros para as Fase 1.2 IFAS 1; Fase 2.1 - IFAS 1; Fase 2.1 - IFAS 2; Fase 2.1 - IFAS 3 e Fase 2.2 - IFAS 1

Tabela 5.17: Valores de $P$ para as principais fases e parâmetros monitorados 98

Tabela 5.18: Eficiências médias de remoção e concentração média efluente dos principais parâmetros para a Fase 2.2 - Reatores IFAS 2 e IFAS 3 99

Tabela 5.19: Valores de $P$ para os principais parâmetros avaliados para a Fase 2.2 Reatores IFAS 2 e IFAS 3

Tabela 5.20: Emissões médias de $\mathrm{N}_{2} \mathrm{O}$ e porcentagens das cargas médias NTK afluente que foram convertidas para $\mathrm{N}_{2} \mathrm{O}$ durante as Fases/Reatores monitorados 103 


\section{LISTA DE ABREVIATURAS, SIGLAS E SÍMBOLOS}

A/M: Relação Alimento/Microrganismo

C/N: Relação carbono/Nitrogênio

CESA: Centro Experimental de Saneamento Ambiental

CH3COONa: Acetato de Sódio

$\mathrm{Cl}^{-}$: Cloretos

$\mathrm{CO}_{2}$ : dióxido de carbono

COS: Cargas Orgânicas Superficial

CV: Coeficiente de variação

d: desnitrificação.

DBA: Densidade de Biofilme Aderida

DBO: Demanda Bioquímica de Oxigênio

DP: Desvio Padrão

DQO: Demanda Química de Oxigênio

$\mathrm{DQO}_{\text {sol }}:$ DQO Soluvel

ETE: Estação de Tratamento de Esgoto

FE: Fator de emissão

IFAS: Integrated Fixed-film Activated Sludge

IPCC: Intergovernmental Panel on Climate Changes

IVL: Índice volumétrico de lodo

LEMA: Laboratório de Engenharia do Meio Ambiente

MBBR: Moving Bed Biofilm Reactor e

n: nitrificação

$\mathrm{N}_{2} \mathrm{O}$ : Óxido Nitroso

$\mathrm{N}_{\mathrm{a}}$ :Concentração de nitrogênio amoniacal 
$\mathrm{N}_{\mathrm{am}}$ : concentração de nitrogênio amonificado no sistema de lodo ativado

$\mathrm{N}_{c}$ : concentração de amônia afluente nitrificada no sistema

$\mathrm{NH}_{4} \mathrm{Cl}$ : Cloreto de Amônio

$\mathrm{N}_{\mathrm{k}}$ :Concentração do NTK

$\mathrm{N}_{1}$ : concentração de nitrogênio orgânico no lodo de excesso

$\mathrm{N}-\mathrm{NH}_{4}^{+}$: Nitrogênio Amoniacal

$\mathrm{N}-\mathrm{NO}_{2}{ }^{-}$: Nitrogênio na forma de Nitrito

$\mathrm{N}-\mathrm{NO}_{3}{ }^{-}$: Nitrogênio na forma de Nitrato

$N_{\circ}$ :Concentração de nitrogênio orgânico

$\mathrm{N}_{\text {oa }}$ : concentração de nitrogênio orgânico afluente

$N_{\text {oe: }}$ concentração de nitrogênio orgânico efluente

NT:Nitrogênio Total

NTK: Concentração de nitrogênio total Kjeldahl

$\mathrm{O}_{3}$ : Ozônio

OD:Oxigênio Dissolvido

pH: Potencial hidrogeniônico

SND: Nitrificação e Desnitrificação Simultânea

SS: Sólidos suspensos

SSF: Sólidos suspensos fixos

SST: Sólidos Suspensão Totais

SSTA: Sólidos Suspensão Totaisno Tanque de Aeração

SSV: Sólidos em Suspensão Voláteis

SSVTA: Sólidos em Suspensão Voláteis no Tanque de Aeração

ST: Sólidos Totais

T: Temperatura 
TDH: Tempo de detenção hidráulica

UFRJ: Universidade Federal do Rio de Janeiro

USP: Universidade de São Paulo

$\Delta$ alc/ $\Delta \mathrm{N}$ : Variação da alcalinidade por $\mathrm{mg} \mathrm{N}$

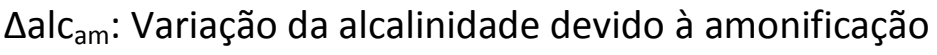

$\Delta a c_{n}$ : Efeito da nitrificação sobre a alcalinidade

$\Delta$ alc $_{\text {obs: }}$ Variação da alcalinidade observada

$\Delta a c_{t}:$ Variação da alcalinidade teórica

$\Delta \mathrm{Na}$ : Variação da concentração de amônia no sistema

$\Delta \mathrm{N}_{\mathrm{d}}$ : Variação da concentração do nitrato no processo de desnitrificação

$\Delta \mathrm{Nn}$ : Variação da concentração de nitrato no sistema

$\theta:$ Idade do lodo 


\section{SUMÁRIO}

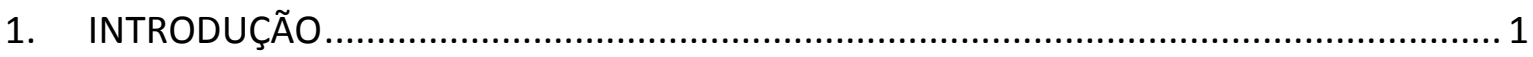

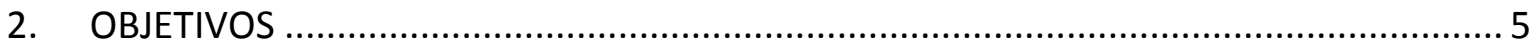

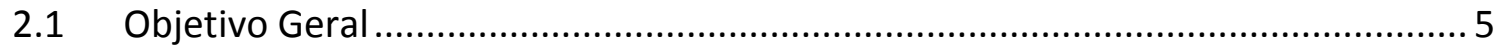

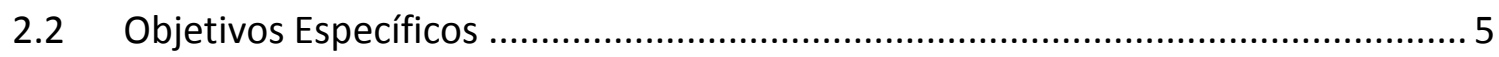

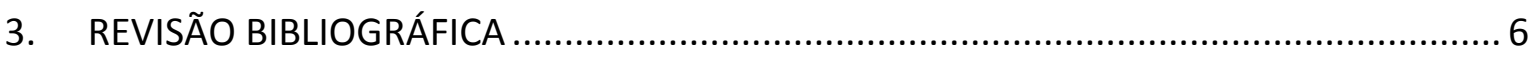

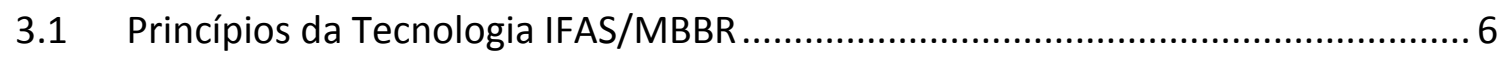

3.2 Princípios do Tratamento Biológico de Efluentes.............................................. 7

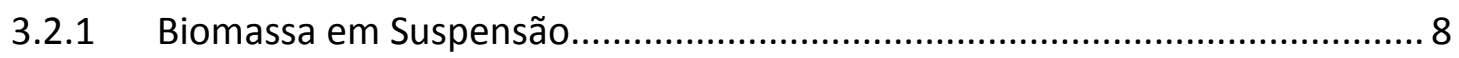

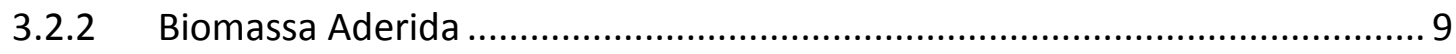

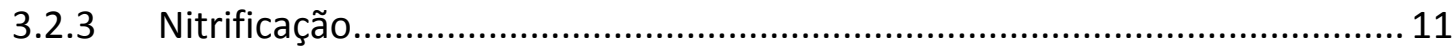

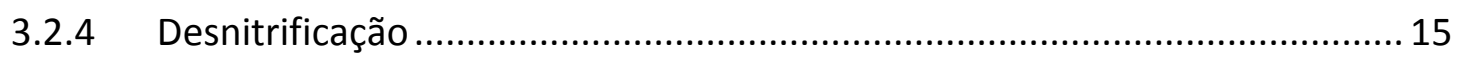

3.2.5 Simultânea Nitrificação e Desnitrificação ................................................... 17

3.2.6 Variação da alcalinidade no processo de remoção de nitrogênio ................. 21

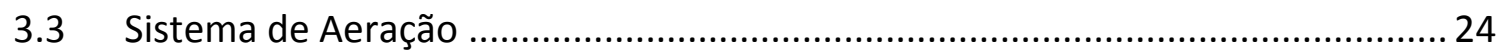

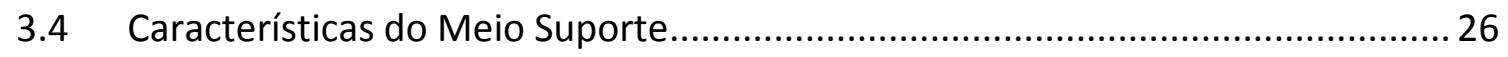

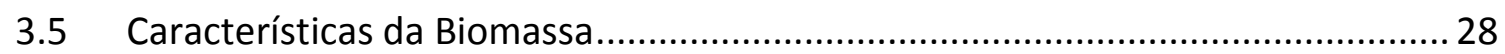

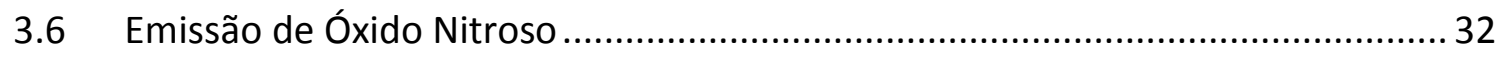

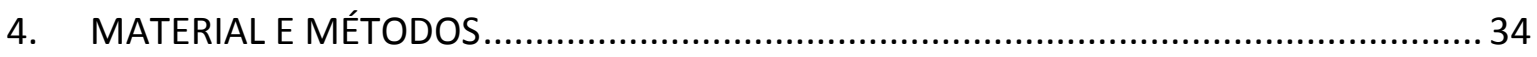

4.1 Centro Experimental de Saneamento Ambiental da Universidade Federal do Rio

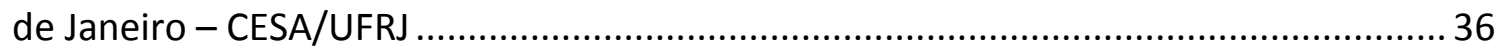


4.2.1 Tratamento Preliminar

4.2.2 Reatores Biológico com Leito Móvel (IFAS) - Unidades Piloto

4.2.3 Sistema de Aeração

4.2.4 Meio Suporte

4.2.5 Condições Operacionais

4.3 Efluente Bruto

4.4 Inóculo e Start-up

4.5 Atividades da Pesquisa

4.5.1 Procedimentos de Operação

4.5.2 Monitoramento e Sistema de Amostragem......

4.5.3 Sólidos Aderidos ao Meio Suporte

4.5.4 Emissão de Óxido Nitroso $\left(\mathrm{N}_{2} \mathrm{O}\right)$. 50

4.5.5 Análise Estatística

5. RESULTADOS E DISCUSSÃO

5.1 Etapa 1

5.1.1 Fase 1.1.......

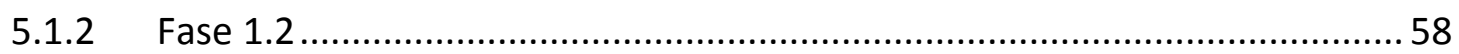

5.2 Etapa 2 64

5.2.1 Fase 2.1...... 64

5.2.2 Fase 2.2 
5.3 Avaliação entre Etapa 1 e Etapa 2 .

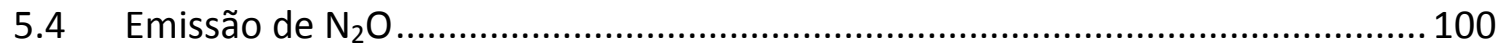

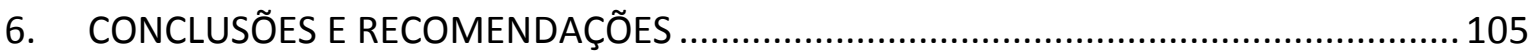

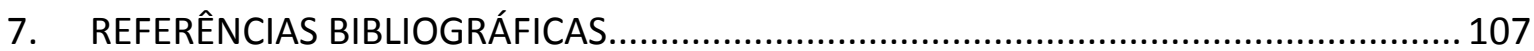




\section{INTRODUÇÃO}

Reator Biológico com Leito Móvel, usualmente conhecido como MBBR ou IFAS, siglas que expressam os termos ingleses: Moving Bed Biofilm Reactor e Integrated Fixed-film Activated Sludge, respectivamente, é uma tecnologia que foi desenvolvida segundo a necessidade de aperfeiçoar o desempenho e/ou aumentar a capacidade de tratamento de estações de lodos ativados já existentes, sem requerer a ampliação física do reator biológico, e consequentemente a realização de obras civis de maior porte ( $\varnothing \mathrm{DEGAARD}$ et al., 1994).

Observa-se que a motivação para o desenvolvimento da tecnologia é oportuna e vai ao encontro da realidade de grande quantidade de estações de tratamento existentes, inclusive no Brasil, que encontram-se sobrecarregadas, deficientes e sem disponibilidade de espaço físico para ampliação.

A difusão do emprego de reatores MBBR/IFAS é reportada no final da década de 1980, tendo-se até 2006 a indicação da aplicação de mais de 400 unidades em todo mundo, contemplando o tratamento de esgotos sanitários e de efluentes industriais, por meio do emprego de processos aeróbios, anaeróbios e anóxicos (RUSTEN et al., 2006; JONOUDet al., 2003; HEM et al., 1994; ØDEGAARD et al., 1993).

$\mathrm{O}$ processo MBBR/IFAS mantém em suspensão no interior do reator meios suporte plásticos de baixa densidade, que sujeitos à agitação promovida pelo sistema de aeração ou pelo misturador, apresentam elevada mobilidade e, por consequência, exposição e contato com a massa líquida em suspensão. Consiste, portanto, em um reator biológico híbrido, no qual organismos decompositores são mantidos tanto em suspensão na massa líquida, como também aderidos aos meios suporte. Consequentemente, em um mesmo volume de reator biológico é possível manter maior quantidade de biomassa e assim aportar maior quantidade de substrato para biodegradação.

As eficiências de remoção de matéria orgânica de esgotos sanitários reportadas na literatura são similares às do processo de lodos ativados, alcançando valores da ordem de até 98\% (ØDEGAARD et al. 1993, 1994). Observa-se que o desempenho do processo é diretamente dependente da disponibilidade de meio suporte e da consequente formação de biofilme. Assim, além da influência da carga volumétrica, o processo depende da 
aplicação de adequada carga superficial, expressa como a razão entre a carga orgânica ou nitrogenada afluente e a área superficial total devida ao meio suporte (RUSTEN et al., 1998).

A redução volumétrica do reator biológico garantida pelo processo MBBR/IFAS pode ser interpretada como a redução do tempo de detenção hidráulica (TDH), ou como o aporte de maior carga orgânica. De qualquer forma, tem-se a configuração de sistemas mais compactos e, como características de processos com biomassa aderida, mais robustos para o enfrentamento de picos de variação de cargas orgânica e hidráulica, substâncias tóxicas e variações das condições ambientais, além de possuir elevada Idade do lodo (WANGet al., 2006; RUSTEN et al., 1998; ØDEGAARD et al., 1994).O processo pode admitir a supressão da operação de recirculação do lodo, no caso da configuração MBBR.

Em contrapartida, entende-se que o processo, além de requerer maior aporte de ar para mvanutenção dos meios suporte em movimentação, exige maior quantidade de oxigênio para a respiração a ser exercida pela maior quantidade de microrganismos (em suspensão e aderidos).

O meio suporte de baixa densidade consiste em peças plásticas de pequena dimensão e elevada área superficial, e sobre o qual reside a lógica da nomeclatura processo MBBR/IFAS.

O processo, por ser de desenvolvimento relativamente recente, requer a condução de estudos de investigação que permitam a melhor compreensão da interação entre a biomassa aderida e em suspensão, da cinética de crescimento e desprendimento do biofilme e dos parâmetros que caracterizam a biomassa autotrófica e heterotrófica e, principalmente, em relação ao fenômeno de Simultânea Nitrificação e Desnitrificação (SND).

Este fenômeno significa que em um mesmo reator ocorre simultaneamente a nitrificação e desnitrificação, sob condições de operações idênticas (aeróbias), o qual vem sendo pesquisado na última década (ZHU et al., 2007). A SND pode ser justificada, segundo ZHANGet al., (2007), pelas teorias de microambiente no floco/biofilme, da nitrificação heterotrófica ou da desnitrificação aeróbia. 
Desta maneira, muitas ETEs poderão se aproveitar desse fenômeno (SND) de forma a se obter o benefício técnico da desnitrificação e o ganho econômico relativo à redução no consumo de energia elétrica para aeração, merecendo assim maior aprofundamento sobre o conhecimento teórico deste processo.

Ademais, para aprimorar racionalmente o sistema MBBR/IFAS com remoção de nitrogênio via SND é preciso que se compreende a estequiometria e a cinética das populações bacterianas que se desenvolvem em tais sistemas. Essa cinética pode ser afetada por diversos fatores ambientais e operacionais, aos quais as bactérias estão submetidas, sendo: temperatura, concentração disponível de oxigênio dissolvido (OD), pH e, também, da configuração de projeto. Modelos matemáticos são amplamente utilizados para descrever a cinética de processos biológicos e auxiliam, de forma eficaz, na determinação de relações estequiométricas (PLATTES et al. 2006; FERRAl et al. 2010).

As constantes cinéticas da nitrificação são críticas na compreensão do modo de funcionamento do sistema de tratamento de esgoto, além de definirem parâmetros importantes para esses, tais como: a idade de lodo mínima e máxima que pode ser aplicada, o volume dos meio suportes visando a SND máxima, concentração mínima e máxima de OD, etc (PLATTES et al. 2008).

As bactérias responsáveis pela remoção de nitrogênio são capazes de produzir enzimas que catalisam as reações de oxidação das formas nitrogenadas. Ensaios de laboratório podem ser realizados para avaliar a cinética dessas reações avaliando-se as mudanças na concentração dos substratos ou produtos envolvidos (amônia, nitrito, nitrato, oxigênio dissolvido, etc).

Além disso, com o avanço de estudos visando remoção biológica de nitrogênio, veio a preocupação quanto a geração de Óxido Nitroso $\left(\mathrm{N}_{2} \mathrm{O}\right)$, sendo que este elemento é bastante problemático pelo fato de possuir cerca de 300 vezes maior potencial de aquecimento global quando comparado ao dióxido de carbono $\left(\mathrm{CO}_{2}\right)$.

Estudos encontrados na literatura indicam que a principal condição operacional que ocasiona a elevada produção de $\mathrm{N}_{2} \mathrm{O}$ são: concentração de $\mathrm{OD} \leq 1 \mathrm{mg} \mathrm{O}_{2} \mathrm{~L}-1$, elevada concentração de Nitrito e baixa relação $\mathrm{DQO} / \mathrm{N}$; isto em sistemas de lodos ativados (FOLEY et al., 2010; TALLEC et al., 2006; TALLEC et al., 2008; KAMPSCHREURet al., 2008). 
Diretrizes de 2006 do Intergovernmental Panel on Climate Changes - IPCC para Inventários Nacionais de Gases do Efeito Estufa propõem como fator de emissão 3,2 (2-8) g $\mathrm{N}_{2} \mathrm{O}$ por pessoa ao ano para o caso de estações de tratamento de esgoto com processos de nitrificação e desnitrificação controlados (IPCC, 2006).

Diante disso, pretende-se com o presente trabalho avaliar o processo IFAS, em escala piloto, instalado no Centro Experimental de Saneamento Ambiental da Universidade Federal do Rio de Janeiro (CESA/UFRJ), quando submetido a variações da concentração de OD. Complementando, pretende-se também avaliar a geração de Óxido Nitroso ao longo do período monitoramento do processo. 


\section{OBJETIVOS}

\subsection{Objetivo Geral}

Avaliar o desempenho do processo de Reator Biológico com Leito Móvel (IFAS) a partir da variação da concentração de OD visando a simultânea nitrificação e desnitrificação (SND).

\subsection{Objetivos Específicos}

- Avaliar o desempenho do fenômeno SND com base nas eficiências de remoção de matéria orgânicacarbonácea e compostos nitrogenados;

- Analisar as formaas de crescimento de biomassa com base na quantificação da concentração de SSV;

- Definir os principais parâmetros de projeto e/ou variáveis de controle para o fenômeno SND em IFAS;

- Avaliar a emissão de Óxido Nitrosoem IFAS durante todo período de monitoramento(fenômeno SND). 


\section{REVISÃO BIBLIOGRÁFICA}

\subsection{Princípios da Tecnologia IFAS/MBBR}

"Moving Bed Biofilm Reactor" pode ser traduzido como Reator Biológico com Leito Móvel e consiste em uma tecnologia baseada na combinação entre sistemas dos tipos biomassa em suspensão e biomassa aderida (biofilme). O processo pode ser implementado tanto para o caso de novas ETEs, quanto utilizado de forma adaptada ao processo de lodos ativados de ETEs existentes (RUSTEN et al. 1995; 1997; ØDEGAARD et al. 1993).

No interior do reator biológico são mantidos em suspensão meios suporte plásticos de baixa densidade, que sujeitos à agitação promovida por sistemas de aeração ou de mistura, apresentam elevada mobilidade e, consequentemente, exposição e contato com a massa líquida em suspensão. Trata-se assim de um reator biológico híbrido, no qual organismos decompositores são mantidos tanto em suspensão na massa líquida, como também aderidos ao meio suporte.

O conceito para o emprego de meios suporte no reator biológico consiste na criação de área superficial para o crescimento de biomassa e elevação do tempo de retenção celular. A maior concentração de sólidos mantida aderida e em suspensão no reator permite o aumento da decomposição da matéria orgânica carbonácea e da conversão de compostos nitrogenados, o que resulta no requisito de menores volumes de reator.

A tecnologia MBBR pode ter como objetivo a remoção de matéria orgânica carbonácea e a nitrificação e, de acordo com configurações específicas, a desnitrificação e ainda a remoção de fósforo.

Observa-se que quando não se aplica a decantação secundária, o reator biológico contém elevada quantidade de meios suporte, possibilitando manter grande quantidade de biomassa aderida e pouca quantidade de sólidos em suspensão na massa líquida. Quando empregada a recirculação secundária, a tecnologia é denominada "Integrated Fixed-Film Activated Sludge" - IFAS, a qual nada mais é do que um sistema de Lodos Ativados contendo meios suporte em suspensão.

Em geral, a maior aplicação da tecnologia tem como objetivo incrementar o desempenho de unidades de tratamento biológico já existentes, por meio da transformação de 
processos de lodos ativados em IFAS ou como unidade complementar, combinada ou não a remoção físico-química.

No caso de câmaras anóxicas ou anaeróbias, é requerida a instalação de equipamentos de mistura, de forma a evitar a sedimentação de sólidos e promover a movimentação dos meios suporte no interior do reator. Para o caso de câmaras aeróbias, o próprio sistema de aeração empregado para a transferência do oxigênio é responsável pela mistura do meio e manutenção dos meios suporte em movimento. Reatores MBBR/IFAS somente empregam aeração por ar difuso, de forma que a estrutura física dos meios suporte seja preservada.

A Figura 3.1 ilustra os tipos de sistema de aeração e mistura usualmente empregados em reatores MBBR/IFAS.
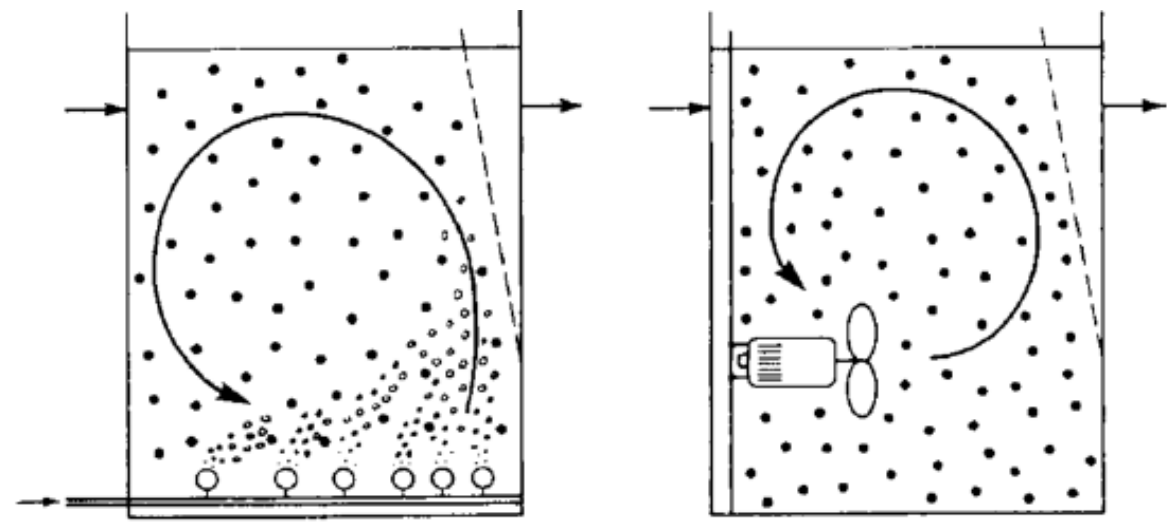

Figura 3.1:Princípio do funcionamento da tecnologia MBBR/IFAS

Fonte: RUSTEN et. al(1994)

Com a imobilização da biomassa em forma de biofilme, entende-se que a idade do lodo eleva-se, favorecendo o desenvolvimento de microganismos de crescimento lento, como os nitrificantes (SRIWIRIYARAT \& RANDALL, 2005; KERMANlet. al 2008).

\subsection{Princípios do Tratamento Biológico de Efluentes}

Como anteriormente mencionado, a tecnologia MBBR/IFAS depende da ação da biomassa aeróbia em suspensão e aderida. Como em qualquer processo biológico, em ambos os casos há presença de bactérias, protozoários, rotíferos, etc, sendo que os principais agentes decompositores da matéria orgânica carbonácea são as bactérias heterotróficas (VON SPERLING, 1996). 
Além de desempenharem a depuração da matéria orgânica, as bactérias possuem a propriedade de se aglomerarem em unidades estruturais como flocos, biofilmes ou grânulos (VON SPERLING, 1996).

Ademais, o tratamento de esgotos por processo aeróbios podem também incorporar outros objetivos, os quais dependem de grupos específicos de bactérias, tais como a conversão de nitrogênio amoniacal a nitrito e em seguida o nitrito a nitrato, ou seja, a nitrificação pelas bactérias autotróficas (VON SPERLING, 1996; METCALF \& EDDY, 2003).

Assim, a utilização do substrato disponível no meio pela ação das bactérias se dá basicamente de acordo com dois principais mecanismos: ação de endoenzimas bacterianas após a absorção da matéria orgânica facilmente biodegradável (solúvel); e a atuação de exoenzimas bacterianas sobre a matéria orgânica de degradação lenta (particulada ou em suspensão), por meio de hidrólise, a fim de solubilizá-la e torná-la também assimilável.

A efetiva assimilação das moléculas de substrato é devida à passagem das mesmas pela membrana celular da bactéria, cuja estrutura flexível e semipermeável permite a seleção de substâncias requeridas pelo seu metabolismo (METCALF \& EDDY, 2003).

\subsubsection{Biomassa em Suspensão}

Com relação à biomassa em suspensão, os microrganismos tendem a se concentrar, formando uma unidade estrutural mais ampla denominada floco. Este apresenta uma estrutura heterogênea contendo material orgânico adsorvido, material inerte também presente nos esgotos, material microbiano produzido para a estruturação da própria matriz do floco e outras células vivas e mortas (VON SPERLING, 1996). Além das bactérias e protozoários, fungos, rotíferos, nematóides e outros estão também presentes no floco.

A formação do floco se deve à produção de uma matriz constituída por bactérias filamentosas, a qual se aderem os outros microrganismos. Indica-se que esta aderência ocorra através de exopolissacarídeos, na forma de camada gelatinosa, o que permite a aglutinação de outros microrganismos e partículas coloidais, e consequentemente, o aumento do diâmetro do floco, formando estruturas macroscópicas mais facilmente sedimentáveis (VON SPERLING, 1996; METCALF \& EDDY, 2003). 
De acordo com o crescimento dos flocos, cujos diâmetros são compreendidos entre 50 a $500 \mu \mathrm{m}$, poderá existir um gradiente de concentração de substratos e oxigênio dissolvido (OD) entre as faces externa e interna de sua estrutura, possibilitando a criação de condições anóxicas em seu interior, como ilustra a Figura 3.2. Complementarmente, a Figura 3.3 destaca a biomassa em suspensão em um reator IFAS.

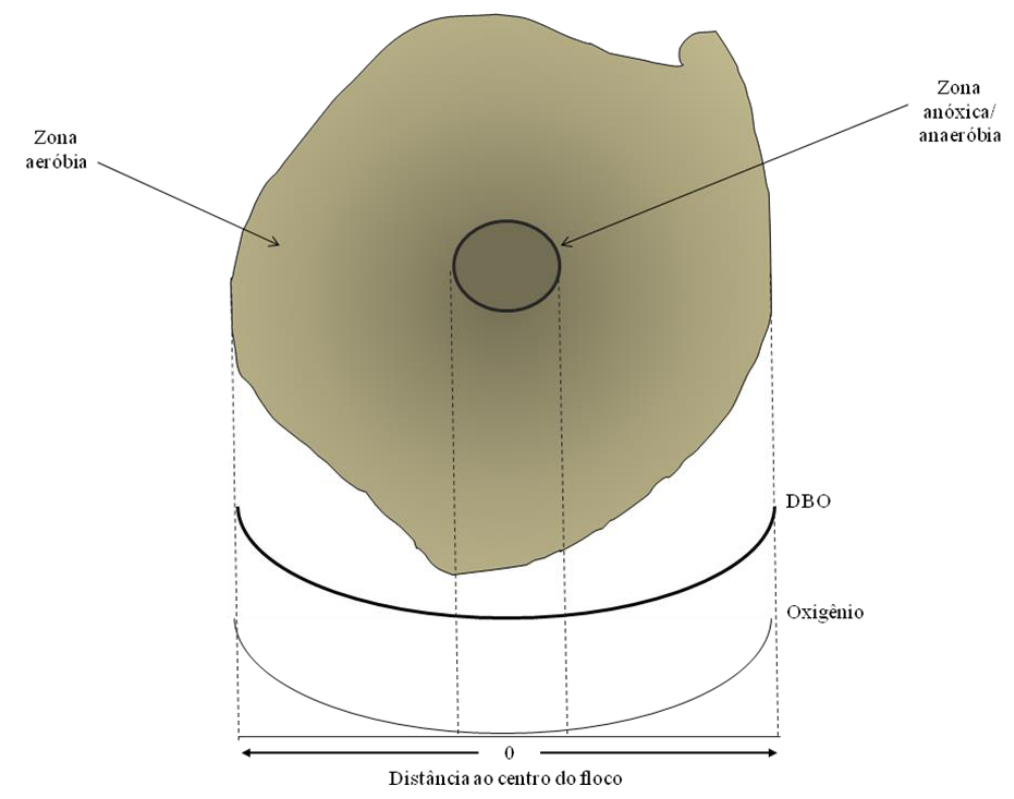

Figura 3.2: Representação esquemática dos gradientes de OD e DBO no floco Fonte: Adaptado de VON SPERLING (1997)

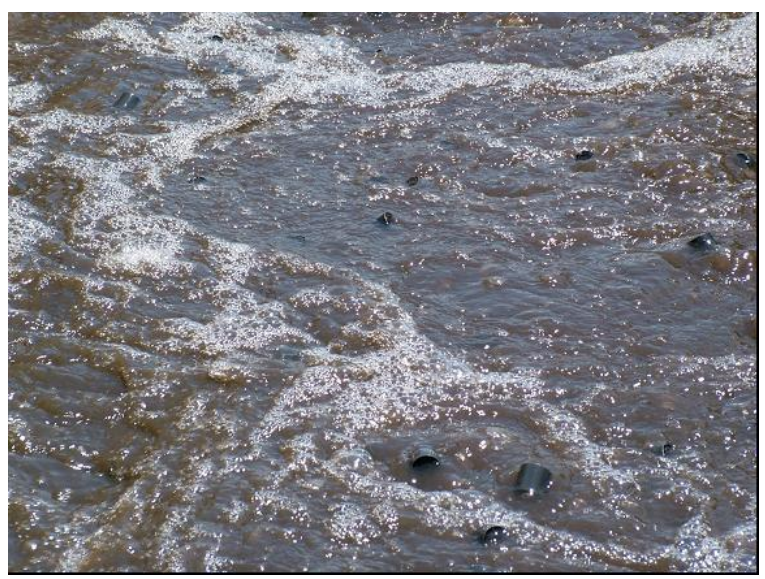

Figura 3.3: Presença de biomassa em suspensão

\subsubsection{Biomassa Aderida}

Os microrganismos que correspondem à biomassa aderida produzem polímeros extracelulares responsáveis pelo potencial adesão físico-química das mesmas a um determinado tipo de meio suporte. A imobilização da biomassa possibilita a sua elevada 
concentração no reator com elevados períodos de tempos. De acordo com ROUXHET \& MOZES (1990) apud VON SPERLING (1996), a aderência da biomassa é influenciada por interações entre células, pelo potencial que oferecem as moléculas de polímeros e a própria composição do substrato.

No caso dos processos aeróbios de biomassa aderida, os princípios de remoção da matéria orgânica e de conversão dos compostos nitrogenados são ainda mais influenciados pelos mecanismos de difusão e de transferência de oxigênio e de substrato solúvel através do biofilme.

De fato, o aumento da espessura do biofilme em função da síntese de novas células, dificulta a difusão de OD e substrato, desde o meio externo até as camadas internas, junto à superfície do meio suporte, onde o processo de estabilização pode ocorrer até mesmo em condições anaeróbias.

A Figura 3.4 apresenta de forma esquemática o consumo de substrato e a geração de subprodutos decorrentes das reações bioquímicas em processos com formação de biofilme.

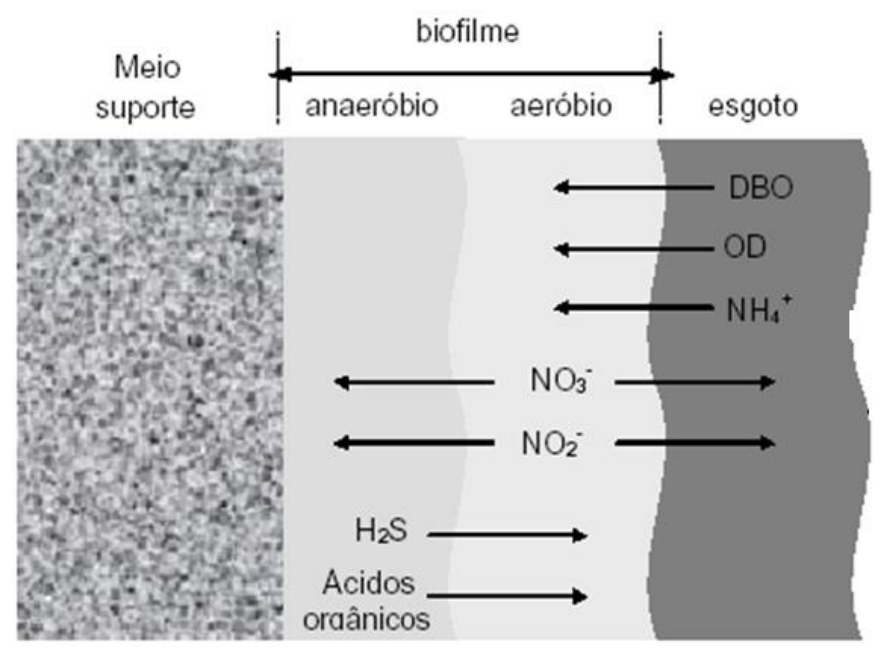

Figura 3.4: Representação esquemática de uma seção de biofilme Fonte: Adaptado de METCALF \& EDDY (2003)

A indisponibilidade de $O D$ e/ou substrato para os microrganismos mais próximos à superfície do meio suporte decorre em processo de metabolismo endógeno, e consequentemente, em perda da capacidade de adesão e desprendimento do biofilme. 
O processo MBBR/IFAS tem ainda o choque entre os meios suportes devido à turbulência no interior do reator como um fator de cisalhamento e desprendimento da biomassa aderida. Valores de espessura do biofilme em processo MBBR indicados pela literatura variam de 0,1 $\mathrm{mm}$ até $1 \mathrm{~mm}$, sendo o menor valor aquele mais reportado ( $\varnothing D E G A A R D$ et al., 1993; ØDEGAARD et al., 1994; RUSTEN et al., 1998; ANDREOTTOLA et al., 2003a; ANDREOTTOLA et al., 2003b). A Figura 3.5 destaca a formação e aderência de biomassa em meios suporte empregado no processo MBBR/IFAS.

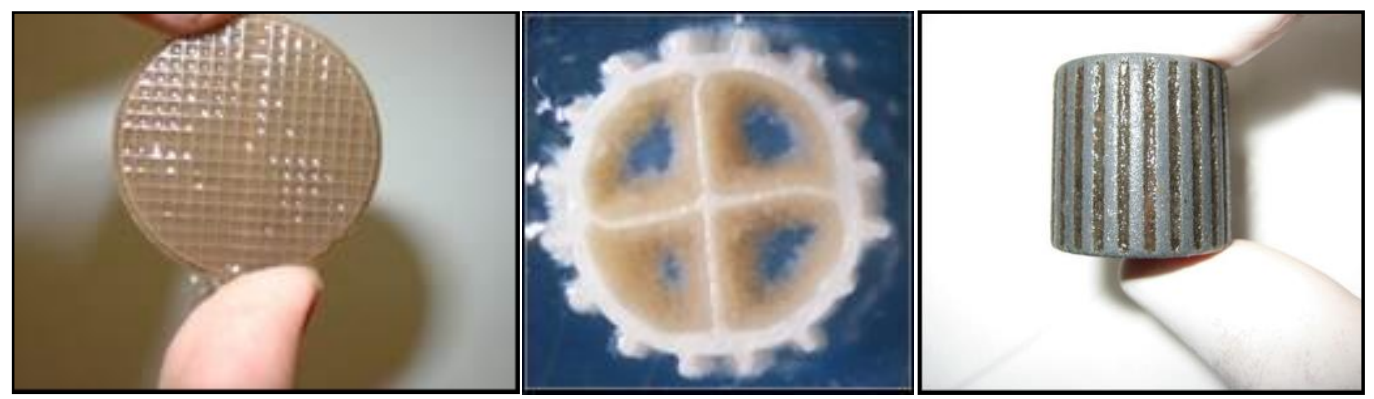

Figura 3.5: Biomassa aderida aos meios suporte

A dinâmica de conversão dos compostos nitrogenados no processo MBBR/IFAS acompanha a mesma que ocorre em outros processos biológicos. Desta forma, a cinética da nitrificação e desnitrificação é influenciada pelos mesmos fatores ambientais, tais como: a relação entre Carbono e Nitrogênio $(\mathrm{C} / \mathrm{N})$, temperatura, $\mathrm{pH}$, alcalinidade, $\mathrm{OD}$, toxicidade, entre outros (VON SPERLING, 1997; METCALF \& EDDY, 2003; FERREIRA, 2002; JORDÃO \& PESSÔA, 2014).

\subsubsection{Nitrificação}

Sabe-se que a nitrificação é um processo autotrófico, onde os microrganismos utilizam dióxido de carbono (carbono inorgânico) para a síntese celular, e que o rendimento celular por unidade de substrato metabolizado é inferior ao rendimento celular dos processos heterotróficos. Dois gêneros de bactérias autotróficas são usualmente reportados como as responsáveis pela nitrificação: Nitrosomonas e Nitrobacter. As bactérias do gênero Nitrosomonas oxidam a amônia a nitrito, o qual é convertido a nitrato pela ação de bactérias do gênero Nitrobacter. SCHMIDT et al. (2003) sugerem outros gêneros de bactérias envolvidos no processo de nitrificação e os classificam como nitrato-oxidantes, que incluem a Nitrospira e o Nitrosococcus, e como nitrito-oxidantes, especificamente a Nitrospira. 
A nitrificação é inibida pela aplicação de elevadas cargas orgânicas, que proporcionam o crescimento de microrganismos heterotróficos, os quais competem por oxigênio e nutrientes com os microrganismos autotróficos nitrificantes, de acordo com taxas de crescimento até cinco vezes maior (SCHMIDT et al. 2003). Segundo METCALF \& EDDY (2003), a fração de microrganismos nitrificantes pode ser relacionada à razão de $\mathrm{DBO}_{5} / \mathrm{NTK}$; valores superiores a 5 limitam a presença de microrganismos nitrificantes em $5 \%$ da população microbiana.

O consumo de oxigênio livre devido aos microrganismos nitrificantes é geralmente referido como a demanda nitrogenada de oxigênio, a qual teoricamente requer 4,57 $\mathrm{mg}$ de $\mathrm{O}_{2}$ por mg de nitrogênio amoniacal convertido a nitrato.

A temperatura e o pH também afetam a taxa de nitrificação. Elevadas temperaturas tornam o processo de nitrificação mais dinâmico, impondo-o elevado consumo de oxigênio e de alcalinidade em função da liberação de $\mathrm{H}^{+}$e da redução do $\mathrm{pH}$. Teoricamente, 7,14 mg de alcalinidade são consumidas por $1 \mathrm{mg}$ de $\mathrm{N}^{-\mathrm{NH}_{4}}{ }^{+}$oxidado (METCALF \& EDDY, 2003; VON SPERLING, 1997). Em baixas temperaturas, as bactérias nitrificantes perdem atividade. $\mathrm{O} \mathrm{pH}$ ótimo para as bactérias nitrificantes é ligeiramente alcalino, na faixa compreendida entre 7,2 e 9,0 (ABREU, 1994; METCALF \& EDDY, 2003).

Como todo processo biológico, a nitrificação é sensível à presença de compostos tóxicos, tais como metais pesados e compostos orgânicos (VON SPERLING, 1997; METCALF \& EDDY, 2003; FERREIRA, 2002).

Experimento de FERREIRA (2002), como ilustra o gráfico da Figura 3.6, demonstrou a influência da idade do lodo sobre a taxa de nitrificação.

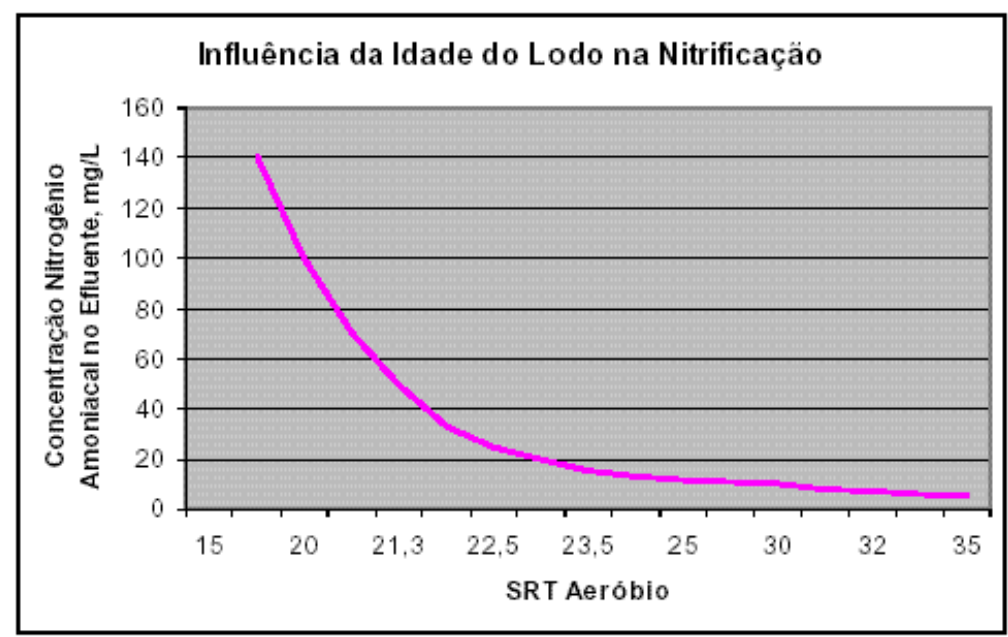


Figura 3.6: Relação entre taxa de nitrificação e idade do lodo

Fonte: FERREIRA (2002)

Em relação a tecnologia MBBR/IFAS, Rusten et al. (1995) desenvolveram pesquisa com um sistema MBBR com reatores em série envolvendo pré-desnitrificação por meio de recirculação interna. O esgoto utilizado na pesquisa, desenvolvida na Noruega, demonstrou-se diluído e de baixa alcalinidade, recebendo anteriormente apenas tratamento preliminar. A temperatura ambiente era inferior a $10^{\circ} \mathrm{C}$. Um dos resultados mais importantes foi o correlacionamento entre a carga de nitrogênio amoniacal aplicada e a taxa de nitrificação, reproduzida na Figura 3.7.

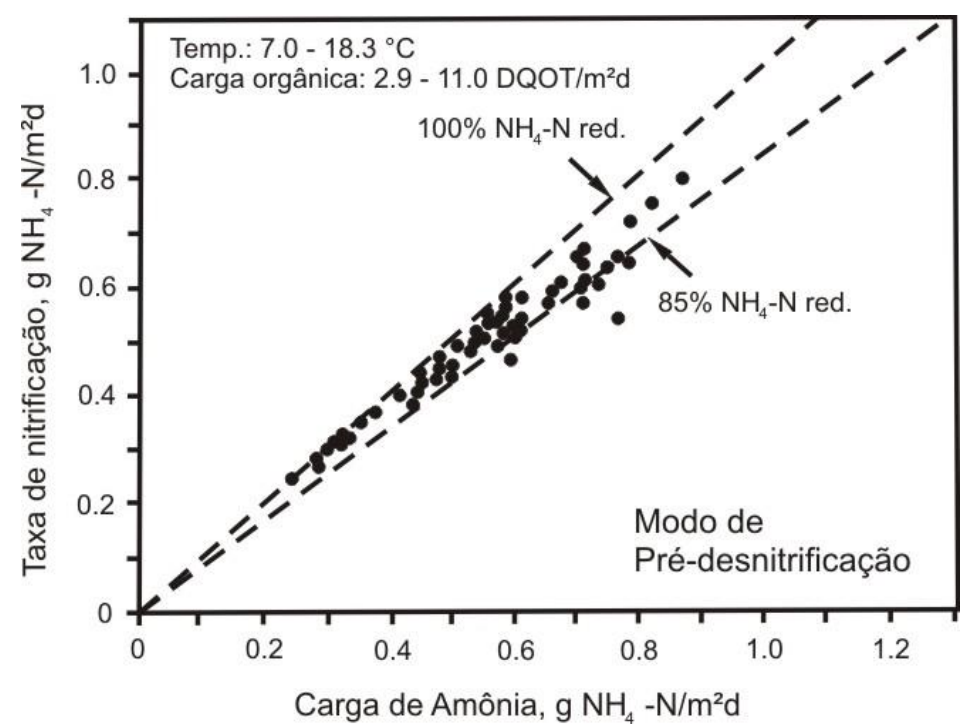

Figura 3.7: Relação entre a carga de nitrogênio amoniacal e a taxa de nitrificação no experimento conduzido por RUSTENet al. (1995)

Pode-se observar taxas elevadas de conversão de $\mathrm{N}-\mathrm{NH}_{4}$ obtidas sob taxa de aplicação de

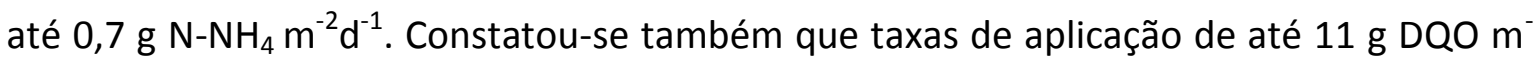
${ }^{2} \mathrm{~d}^{-1}$ não interferiram na nitrificação, principalmente por que boa parte dela foi consumida na câmara anóxica.

Nos estudos desenvolvidos pelo mesmo grupo de pesquisadores noruegueses, principais responsáveis pela evolução dessa tecnologia, foi obtida a correlação entre taxa de nitrificação e concentração de oxigênio dissolvido reproduzida na Figura 3.8. 


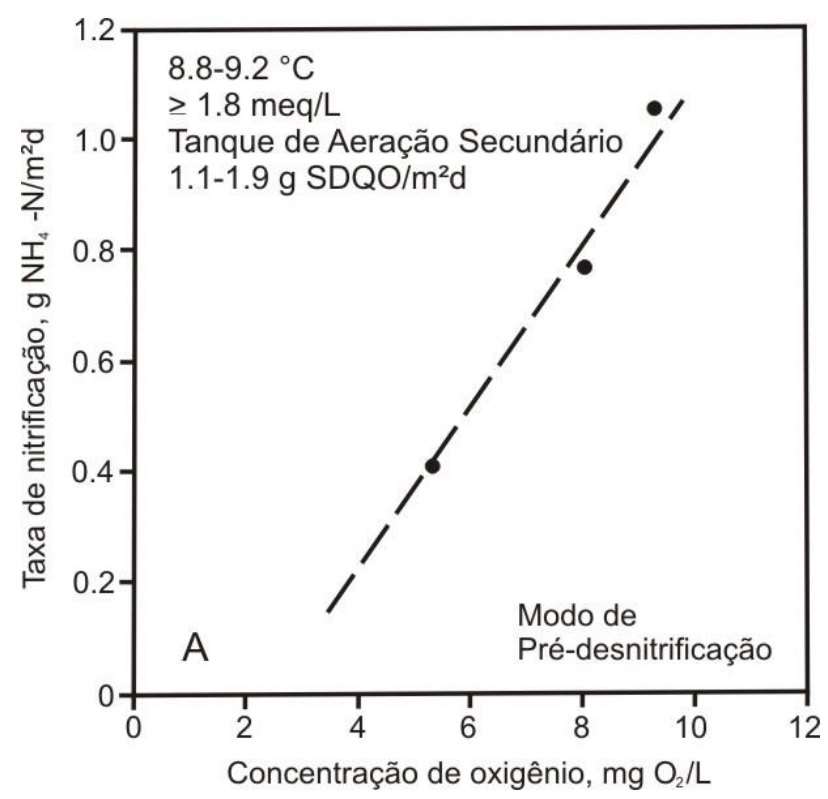

Figura 3.8: Relação entre taxa de nitrificação e concentração de oxigênio dissolvido em sistema com MBBR em escala piloto (RUSTENet al., 1995)

Inferiu-se que a camada líquida à superfície do biofilme formado nos meios suporte é limitante para a transferência de oxigênio. Como o OD é consumido para degradação de matéria orgânica por microrganismos heterotróficos, que se posicionam na parte externa do biofilme, para obtenção da nitrificação o nível de oxigênio dissolvido deve ser elevado para que haja penetração nas camadas internas, região em que predominam as bactérias nitrificantes. Nesta Figura 3.8, observa-se uma relação linear entre a concentração de OD e a taxa de nitrificação. A reta deve interceptar o eixo das abscissas em torno de $2,5 \mathrm{mg}$ $\mathrm{O}_{2} \mathrm{~L}^{-1}$, faixa considerada mínima para ocorrência da nitrificação. Essa constatação é muito relevante, uma vez que o consumo de energia elétrica para aeração do sistema deverá ser substancialmente maior relativamente ao processo de lodo ativado apenas com biomassa em suspensão, em que a concentração de OD é mantida entre 1,0 e 2,0 mg $\mathrm{O}_{2} \mathrm{~L}^{-1}$.

Já HEM et al. (1994), em um reator MBBR trabalhando com Cargas Orgânicas Superficial (COS) maior que $5 \mathrm{~g} \mathrm{DBO}_{7} \mathrm{~m}^{-2} \mathrm{~d}^{-1}$, observaram que a taxa de nitrificação é quase nula. $\mathrm{O}$ mesmo autor ilustra a relação entre a concentração de OD, a COS aplicada e a taxa de remoção de $\mathrm{N}-\mathrm{NH}_{4}$ por meio do gráfico da Figura 3.9. 


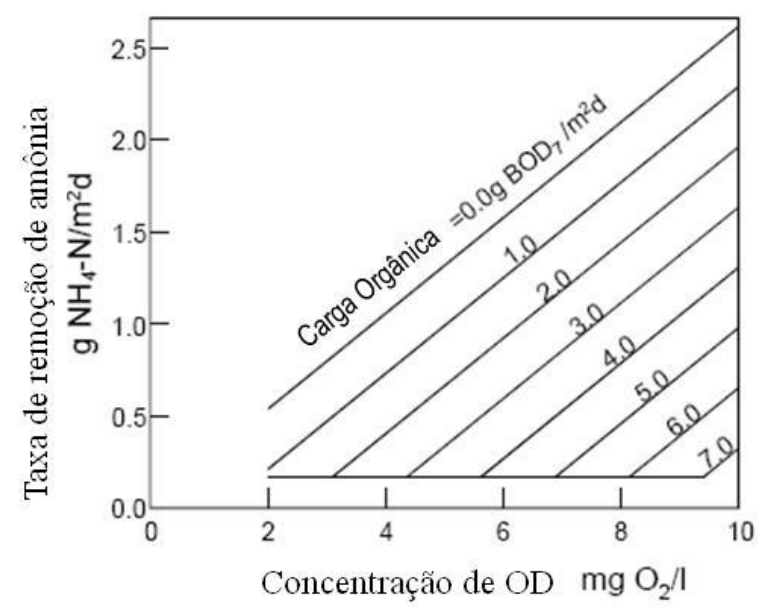

Figura 3.9: Relação entre a concentração de $\mathrm{OD}$ e a COS com taxa de remoção de $\mathrm{N}-\mathrm{NH}_{4}$ (HEM el al.1994)

\subsubsection{Desnitrificação}

O processo de desnitrificação consiste na conversão de nitrato a nitrogênio gasoso pela ação de bactérias heterotróficas anaeróbias ou facultativas em condições anóxicas. A reação bioquímica de desnitrificação em ambiente anóxico envolve grande diversidade de microrganismos, tais como: Achromobacter, Bacillus, Brevibacterium, Flavobacterium, Lactobacillus, Micrococcus, Proteus, Pseudomonas e Spirillum. Dentre estes, a espécie de bactéria Pseudomonas é aquela que mais prepondera (METCALF \& EDDY, 2003; AKUNNA et al., 1993).

Esse processo consta inicialmente na reconversão do nitrato, como aceptor de elétrons, a nitrito; que por sua vez, consecutivamente, é convertido aos gases óxido nítrico, óxido nitroso e nitrogênio molecular, os quais podem ser liberados para a atmosfera.

Para a desnitrificação, além do nitrato a ser convertido é também necessária a disponibilização de substrato orgânico oxidável (AKUNNA et al., 1993, VON SPERLING, 1997; METCALF \& EDDY, 2003; JORDÃO \& PESSÔA, 2014). Efluentes nitrificados possuem baixas concentrações de matéria carbonácea, o que pode requerer o aporte externo de carbono, podendo o afluente bruto ao sistema ser utilizado como fonte de suprimento necessária ao processo de desnitrificação (ARCEIVALA, 1981 apud VON SPERLING, 1997; METCALF \& EDDY, 2003; JORDÃO \& PESSÔA, 2014). 
O transporte de elétrons requerido pela desnitrificação depende de enzima específica cuja produção é inibida pela presença de OD. Ademais, a combinação entre a ainda eventual presença de matéria orgânica e OD favorecerá a ação de bactérias heterotróficas aeróbias e comprometerá a ação dos microrganismos desnitrificantes (METCALF \& EDDY, 2003).

O processo de desnitrificação produz alcalinidade. Assim, de acordo com VON SPERLING (1997) e VAN HAANDEL \& MARAIS (1999) o aumento de alcalinidade gerado durante a desnitrificação é compensado pelo consumo desta em sistemas combinados com a nitrificação.

$\mathrm{O}$ pH ótimo para a desnitrificação é em torno de 7,0 a 8,0. Organismos desnitrificantes podem tolerar uma faixa de $\mathrm{pH}$ entre 6,0 e 9,0 (DINÇER \& KARGI, 2000). O valor ótimo específico é variável de acordo com o tipo de bactéria presente no meio (WPCF, 1983 apud TEIXEIRA, 2006). O pH é elevado como resultado do consumo de íons $\mathrm{H}^{+}$disponíveis no meio e do consequente aumento de alcalinidade (DINÇER \& KARGI, 2000; VON SPERLING, 1997; METCALF \& EDDY, 2003; JORDÃO \& PESSÔA, 2014).

A reação de desnitrificação ocorre em uma faixa ótima de temperatura compreendida entre 35 e 50 ㅇ. A temperatura afeta tanto o crescimento microbiano quanto a velocidade de remoção de nitrato (BARNES \& BLISS, 1983 apud VON SPERLING, 1997).

Para a desnitrificação, a configuração dos processos biológicos de tratamentos de esgotos requer a combinação entre ambientes anóxico e aeróbio, obedecendo principalmente às seguintes modalidades:

- Pré-desnitrificação, na qual a fonte de carbono é proveniente do esgoto bruto;

- Pós-desnitrificação, na qual a fonte de carbono é proveniente da etapa de respiração endógena;

- Reatores de operação intermitente (batelada).

Estes sistemas têm sido adotados principalmente para as variantes clássicas do sistema de lodos ativados. As modalidades de pré e pós-desnitrificação foram também aplicadas por $\emptyset D E G A A R D$ et al. $(1993)$ e RUSTEN et al. $(1995,1997)$ em processos MBBR. 
No trabalho desenvolvido por RUSTEN et al. (1995), obtiveram a taxa máxima de desnitrificação de $200 \mathrm{~g} \mathrm{~N}-\mathrm{NO}_{x} \mathrm{~m}^{-3} \cdot \mathrm{d}^{-1}$. A velocidade de desnitrificação demonstrou-se diretamente proporcional à DQO solúvel biodegradável. Porém, foram verificados níveis altos de concentração de oxigênio dissolvido, acima de $3,4 \mathrm{mg} \mathrm{L}^{-1}$, contribuindo para a baixa taxa de desnitrificação.

\subsubsection{Simultânea Nitrificação e Desnitrificação}

O fenômeno da Simultânea Nitrificação e Desnitrificação está, ultimanente, sendo amplamente pesquisado, o qual significa que em um mesmo reator ocorre concomitantemente a nitrificação e desnitrificação, sob uma única condição operacional (ZHU et al. 2007). A SND pode ser justificada, segundo ZHANGet al.(2007), pelas teorias de microambiente no floco/biofilme, da nitrificação heterotrófica ou da desnitrificação aeróbia.

Dentre essas teorias, a que merece maior destaque é a de microambiente no floco/biofilme, que nada mais é do que a ocorrência de micro zonas anóxicas dentro do floco/biofilme por causa da limitação difusional do OD (ZHU et al. 2007).

Neste contexto, o OD é consumido rapidamente na parte externa do floco/biofilme de maneira que se torna indisponível na camada interna. O nitrato produzido na mesma parte externa (zona aeróbia) pode difundir-se em direção à camada interna conjuntamente com o substrato, ocorrendo a desnitrificação (METCALF \& EDDY, 2003; ZHANGet al. 2007).

Em relação aos resultados alcançados reportados pela literatura especializada, é importante enfatizar que, praticamente em todos os artigos publicados, a SND foi pesquisada no processo de Lodos Ativados (aeração prolongada ou em batelada) conforme descrito a seguir, e não para a tecnologia MBBR/IFAS.

BUENO (2011) trabalhou com um sistema de lodo ativado por aeração prolongada alimentada em fluxo contínuo com diferentes idades do lodo 40, 30 e 20 dias e relação A/M 0,05; 0,075 e 0,10 gDBO gSSV ${ }^{-1} \mathrm{~d}^{-1}$, tratando esgoto sanitário e mantendo concentrações de $\mathrm{OD}$ no tanque de aeração na faixa de 0,3-0,8 $\mathrm{mg} \mathrm{L}^{-1}$. Os melhores resultados para SND foram obtidos para idade do lodo de 40 dias ( $A / M$ de 0,05 gDBO 
gSSV $^{-1} \mathrm{~d}^{-1}$ ), com concentrações médias efluentes de NTK da ordem de 6,0 $\mathrm{mg} \mathrm{L}^{-1}$ e de $\mathrm{NO}_{3}{ }^{-}$igual a $0,9 \mathrm{mg} \mathrm{L}^{-1}$ e remoção de DQO e DBO acima de $90 \%$.

Em estudos realizados com dois reatores em batelada trabalhando em paralelo, sendo um formado por lodos ativados e o outro por lodos ativados contendo mídias fixas (350 $\mathrm{m}^{2} \mathrm{~m}^{-3}-33 \%$ volume), a fim de comparar as eficiências de remoção de matéria orgânica, nitrogenada e fósforo, a qualidade e a produção de lodo; RAHIMI et al. (2011) empregaram esgoto sintético simulando esgoto doméstico, $\mathrm{pH}$ de 6,5 a 7,5, ciclos de operação de 4, 6 e 8 horas sem que haja nenhum período anóxico ou anaeróbio. Os

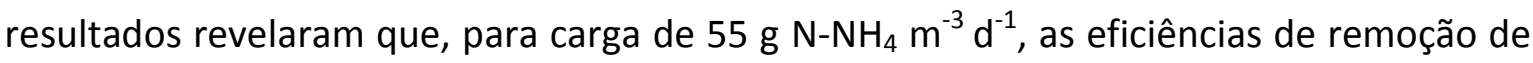
$\mathrm{N}$-total foi de $38 \%$ e $88 \%$, respectivamente para reator sem e com meios suportes. Já quando a carga foi elevada para $222 \mathrm{~g} \mathrm{~N}-\mathrm{NH}_{4} \mathrm{~m}^{-3} \mathrm{~d}^{-1}$ as eficiências modificaram para $44 \%$ e $70 \%$. No entanto, ressalta-se que em ambos os casos, a concentração de N-total efluente foi sempre inferior no reator contendo os meios suportes, indicando que a taxa de SND foi significantemente superior.

ZHANG et al.(2007) realizaram pesquisas em um sistema piloto de lodo ativado por aeração prolongada alimentado em fluxo contínuo com esgoto sintético. Os autores operaram o sistema com idade do lodo $(\theta)$ na faixa de 60,45 e 30 dias com razões de $A / M$ de $0,05-0,30 \mathrm{~g}^{2} \mathrm{DQO} \mathrm{gSSV}^{-1} \mathrm{~d}^{-1}$. A concentração de OD no tanque de aeração foi mantida na faixa de $0,3-0,8 \mathrm{mgL}^{-1}$. O estudo mostra a ocorrência do processo de SND em todas as condições. Porém, na condição onde a $\theta$ foi igual a 45 dias com razão $A / M$ de 0,1 gDQO $\mathrm{gSSV}^{-1} \mathrm{~d}^{-1}$ e uma relação $\mathrm{C} / \mathrm{N}$ de 10 , o sistema apresentou uma melhor eficiência, chegando a 93\% na nitrificação, e em torno de 67\% na remoção de nitrogênio total (NT). Salienta-se que, em um segundo momento, quando os autores reduziram a concentração de OD para $0,01 \mathrm{mg} \mathrm{L}^{-1}$ a remoção de nitrogênio amoniacal e total caiu em torno de 20 pontos percentuais.

Estudos conduzidos por THAURÉ et al. (2008), com baixa concentração de OD (0,5 mg L $\left.{ }^{-1}\right)$, em uma ETE de lodos ativados com aeração prolongada com capacidade de $1000 \mathrm{~m}^{3} \mathrm{~d}^{-1}$, obtendo uma redução de aproximadamente $80 \%$ de NT e de energia elétrica na aeração, na ordem de 10 a 50\%. A ETE foi operada $\operatorname{com} \theta$ de 30 a 40 dias, com razão $A / M$ de 0,03 a $0,05 \mathrm{~kg}$ DQO kg SSV${ }^{-1} \mathrm{~d}^{-1}$ e concentração de SSV no lodo misto de 3 a $4 \mathrm{~g} \mathrm{~L}^{-1}$. Os autores relatam ainda que não foi observado o aparecimento de bactérias filamentosas no licor 
misto e a ocorrência do processo de SND durante o controle de OD em baixas concentrações.

Já ZHU et al. (2007), pesquisaram a SND em uma unidade piloto de lodos ativados com TDH de 8 horas, razão de recirculação de lodo de 50\% e idade do lodo igual a 18 dias, trabalhando com esgoto sintético e variando a concentração de OD de $0,17 \mathrm{mgL}^{-1}$ até 4,57 $\mathrm{mgL}^{-1}$. Os resultados apontaram que, quando a concentração de OD esteve abaixo de 1,0 $\mathrm{mgL}^{-1}$, houve uma maior remoção de NT. Além disso, observaram também um baixo consumo de alcalinidade, que indica a ocorrência da SND.

Por outro lado, KRICHTEN \& MCDOWELL(2003), alcançaram inesperadamente a SND, quando foram ampliar um sistema de lodos ativados existente na empresa Camp Dresser \& McKee - Florida, USA, visando atender o limite máximo de lançamento para amônia ionizada $\left(\mathrm{NH}_{4}^{+}\right.$igual a $\left.0,02 \mathrm{mg} \mathrm{L}{ }^{-1}\right)$. Para essa ampliação, eles introduziram no reator mídias fixas - tipo cross-flow formado por cordas, o qual ocupou um volume aproximado de $30 \%$ em relação ao volume do reator. Os resultados obtidos foram de menos de $7 \mathrm{mg}$ $\mathrm{L}^{-1}$ de nitrito+nitrato quando a concentração média afluente de nitrogênio amoniacal era de $30 \mathrm{mg} \mathrm{L}^{-1}$, isto para uma concentração de OD de,em torno, de $4 \mathrm{mg} \mathrm{L}^{-1}$. Observaram também no laboratório, a presença de bactérias desnitrificantes em uma zona no interior do biofilme formado.

HOLMAN\& WAREHAM (2005) empregaram em seu experimento dois reatores, em paralelo, de lodos ativados em batelada para tratamento de esgoto sintético, onde a temperatura foi mantida em torno de $17 \stackrel{\circ}{ } \mathrm{C}$, o TDH variou de 4 a 12 horas e a razão $\mathrm{C}: \mathrm{N}: \mathrm{P}$ igual a 100:5:1, mas a concentração de $\mathrm{NH}_{3}-\mathrm{N}$ afluente foi variada de $8,5 \mathrm{mg} \mathrm{L}^{-1}$ para 11,0 $\mathrm{mg} \mathrm{L}^{-1}$, depois para $28,0 \mathrm{mg} \mathrm{L}^{-1}$ e por fim a $50,0 \mathrm{mg} \mathrm{L}^{-1}$, alterando também a vazão de ar a fim de manter a concentração de OD em torno de $0,5 \mathrm{mg} \mathrm{L}^{-1}$. Na primeira Fase $\left(\mathrm{N}^{-\mathrm{NH}_{3}=}\right.$ $8,5 \mathrm{mg} \mathrm{L}^{-1}$ ), a remoção de NTfoi de $87,5 \%$, na segunda e terceira Fases, as quais não tiveram uma fase anóxica, houve uma concentração resultante de nitrito e nitrato (aproximadamente 0,8 $\mathrm{mg} \mathrm{L}^{-1}$ ) mas um consumo total do nitrogênio amoniacal, indicando a ocorrência da SND. Por fim, na quarta Fase, apesar da elevada vazão de ar (OD de até 3,6 $\mathrm{mg} \mathrm{L}^{-1}$ ), obtiveram eficiência global de NTde $60 \%$. Portanto, concluíram que a SND é encontrada para concentração de OD igual a $0,2 \mathrm{mg} \mathrm{L}^{-1}$ e bastante prejudicada, devido a desnitrificação aeróbia, para concentrações acima de $1,0 \mathrm{mg} \mathrm{L}^{-1}$. 
XING et al. (2000) estudaram o efeito da relação C/N sobre a SND em um reator de leito fluidizado contendo meios suporte porosos tratando efluente sintético. A concentração de OD foi mantida em torno de 5,0 $\mathrm{mg} \mathrm{L}^{-1}$ e o TDH de 8 horas. Os resultados apontam que as melhores eficiências remoção para COT foi para relação $\mathrm{C} / \mathrm{N}$ de $15 / 2$ igual a 98,7\% e para NT foi para relação $\mathrm{C} / \mathrm{N}$ de $10 / 1$ com eficiência de $85 \%$, equivalente a concentração de média efluente de NT de aproximadamente $10 \mathrm{mg} \mathrm{L}^{-1}$.

No entanto, de acordo com MUNCH et al. (1996) o fenômeno de SND pode também ser observado na tecnologia MBBR/IFAS. Pois a SND se apropria da característica que os processos de biomassa aderida apresentam em relação à limitação da difusão de OD no interior do biofilme. Como anteriormente discutido, no caso dos reatores MBBR/IFAS, e em função da concentração de OD mantida no meio, pode haver a formação de ambientes anóxicos, principalmente nas áreas internas dos meios suporte e na respectiva biomassa aderida, perfazendo a condição ideal para que ocorram tanto a nitrificação como a desnitrificação.

FU et al. (2010) desenvolveram uma pesquisa com três reatores MBBR em série, o qual cada um teve um volume de $3,1 \mathrm{~L}$ com $30 \%$ preenchido pelos meios suportes $\left(500 \mathrm{~m}^{2} \mathrm{~m}^{-}\right.$ $\left.{ }^{3}\right)$. $\mathrm{O} \mathrm{pH}$, a temperatura e a concentração de OD foi mantida constante e, em torno de 7,0 a 8,0, $24 \pm 1$ o C e 3,0 a 4,0 $\mathrm{mg} \mathrm{L}^{-1}$, com TDH de 10h. Salienta-se que foi empregado esgoto sintético com concentração de DQO de 500, 1000 e $1500 \mathrm{mg} \mathrm{L}^{-1}$, visando variar a relação $\mathrm{C} / \mathrm{N}$ de 4,$5 ; 6,0 ; 8,9 ; 11,9$ e 13,4. Para mensuramento da biomassa aderida foi utilizado um aparelho de Ultrassom. Assim, a fase que obteve melhor resultado, tanto para remoção de DQO quanto para SND, foi com C/N igual a 13,4, onde as eficiências médias foram de 96 e 98\%, respectivamente, isso para uma eficiência média de $\mathrm{N}-\mathrm{NH}_{4}$ de $74 \%$.

É importante evidenciar que FUet al. (2010) avaliaram em seu trabalho a comunidade bacteriana aderida aos meios suportes em cada fase (relação $\mathrm{C} / \mathrm{N}$ ), alcançando resultados que indicam que quanto maior foi a relação $\mathrm{C} / \mathrm{N}(8,9 ; 11,9$ e 13,4$)$ maior foi a diversidade de espécies bacterianas. Além disso, os autores observaram a presença de diversos tipos de bactérias, como as Acidovorax sp., que são capazes da redução de nitrato sob condições anóxicas e também da produção de polihidroxibutirato (PHB), o qual pode ser enquadrado como organismo desnitrificante e acumuladores de polifosfato. 
Por fim, o único trabalho encontrado na literatura que empregou a tecnologia MBBR trabalhando de forma similar o que está proposto neste estudo, foi o desenvolvido por WANG et al.(2006), que trataram esgoto doméstico em um único reator MBBR (volume igual a 13 litros), com $50 \%$ do seu volume ocupados por meios suportes os quais possuíam área superficial especifica de $320 \mathrm{~m}^{2} \mathrm{~m}^{-3}$. A temperatura foi mantida constante entre $18-20$ ㅇ e o TDH igual a 6 horas; já a concentração de OD foi variada entre 1,0; 2,0; 4,0 e 6,0 $\mathrm{mg} \mathrm{L}^{-1}$ a fim de avaliar qual sua influência na remoção de matéria orgânica e SND. Dessa maneira, quando a concentração de OD variou de 2 até $6 \mathrm{mg} \mathrm{L}^{-1}$, a eficiência de DQO elevou-se de 71,3\% para 77,1\%, indicando que para remoção de matéria orgânica a concentração de OD foi um fator limitante. Da mesma maneira, quando a concentração de OD esteve entre 2 até $6 \mathrm{mg} \mathrm{L}^{-1}$ eficiência da nitrificação foi acima de 90\%, revelando que é necessário manter o valor de $O D$ em pelo menos $2 \mathrm{mg} \mathrm{L}^{-1}$ para que haja um completa nitrificação em processos MBBR.

Neste mesmo estudo, WANG et al.(2006) observaram que para concentração de OD de $2,0 \mathrm{mg} \mathrm{L}^{-1}$, além da remoção de nitrogênio amoniacal, houve também uma limitada geração de nitrito e nitrato, obtendo eficiência média de NT de 89,9\%. No entanto, quando a concentração de OD foi de $1,0 \mathrm{mg} \mathrm{L}^{-1}$, a eficiência média de NT reduziu para $54,3 \%$, influenciada pela baixa nitrificação. Por outro lado, para concentração de OD igual a 4,0 e 6,0 $\mathrm{mg} \mathrm{L}^{-1}$, a eficiência média de NTde 62,5 e 42,6\%, comprovando a hipótese de que as bactérias desnitrificantes podem mudar o aceptor de elétrons de nitrato para oxigênio, cessando assim a desnitrificação.

\subsubsection{Variação da alcalinidade no processo de remoção de nitrogênio}

Sabe-se que no processo de nitrificação e desnitrificação pode haver um consumo da alcalinidade juntamente com variação do $\mathrm{pH}$. Pois, de acordo com as relações estequiométricas representadas pelas equações a seguir (Equações 5.1 e Eq. 5.2), na nitrificação há produção de 2 moles de $\mathrm{H}^{+}$por mol de nitrato formado, e na desnitrificação há consumo de $1 \mathrm{~mol}$ de $\mathrm{H}^{+}$por mol de nitrato reduzido. Considerando-se que a produção de $1 \mathrm{~mol}$ de $\mathrm{H}^{+}$(acidez mineral) equivale ao consumo de $1 \mathrm{~mol}$ de alcalinidade (igual a $50 \mathrm{~g} \mathrm{CaCO}_{3}$ ), tem-se que no processo de nitrificação, há um consumo de alcalinidade de $2 \times 50=100 \mathrm{~g} \mathrm{CaCO}_{3}$ por mol N (14g) e no processo de desnitrificação, produz-se $50 \mathrm{~g} \mathrm{CaCO}_{3}$ por mol N. 
$(\Delta \mathrm{alc} / \Delta \mathrm{N}) \mathrm{n}=-100 / 14=-7,14 \mathrm{mg} \mathrm{CaCO}_{3} \mathrm{mgN}^{-1}$

$(\Delta \mathrm{alc} / \Delta \mathrm{N}) \mathrm{d}=50 / 14=3,57 \mathrm{mg} \mathrm{CaCO}_{3} \mathrm{mgN}^{-1}$

Onde:

$(\Delta a l c / \Delta N)$ : variação da alcalinidade por mg N; n: nitrificação; d: desnitrificação.

No caso de esgoto sanitário, existe ainda o efeito da amonificação sobre a alcalinidade. Entretanto, essa variação é bastante pequena, dado que a concentração de nitrogênio amonificado no sistema de lodo ativado, por exemplo, é concedida pela diferença entre o nitrogênio orgânico afluente e a soma de nitrogênio orgânico no efluente e no lodo de excesso (Equa ções 5.3 e 5.4).

$(\Delta \mathrm{alc} / \Delta \mathrm{N}) \mathrm{am}=50 / 14=3,57 \mathrm{mg} \mathrm{CaCO}_{3} \mathrm{mgN}^{-1}$

$\mathrm{N}_{\mathrm{am}}=\mathrm{N}_{\mathrm{oa}}-\left(\mathrm{N}_{\mathrm{oe}}+\mathrm{N}_{\mathrm{l}}\right)$

Onde:

$\mathrm{N}_{\mathrm{am}}$ : concentração de nitrogênio amonificado no sistema de lodo ativado ( $\mathrm{mgN} \mathrm{L}^{-1}$ )

$\mathrm{N}_{\circ a}$ : concentração de nitrogênio orgânico afluente $\left(\mathrm{mgN} \mathrm{L}^{-1}\right)$

$\mathrm{N}_{\mathrm{oe}}$ : concentração de nitrogênio orgânico efluente $\left(\mathrm{mgNL}^{-1}\right)$

$\mathrm{N}_{l}$ : concentração de nitrogênio orgânico no lodo de excesso $\left(\mathrm{mgN} \mathrm{L}^{-1}\right)$

Paraesgoto sanitário, normalmente, a concentração do nitrogênio orgânico no efluente é muitobaixa (em torno de 1 a $2 \mathrm{mgN} \mathrm{L}^{-1}$ ), enquanto os valores das concentrações $\mathrm{N}_{\mathrm{oa}} \mathrm{e}$ N,são de 10 a 25 por cento do NTK do afluente (COURA, 2002; DERKS, 2007). Desse modo, a variação da concentração de nitrogênio orgânico é muito pequena e, consequentemente, a variação da alcalinidade quanto à amonificação também será pequena. A variação da alcalinidade devido à amonificação é dada pela Equação 5.5:

$\Delta \mathrm{alc}_{\mathrm{am}}=3,57 \Delta \mathrm{Nam}=3,57\left(\mathrm{~N}_{\mathrm{oa}}-\mathrm{N}_{\mathrm{oe}}-\mathrm{N}_{\mathrm{l}}\right)$

Sendo que o valor de $\Delta$ alcampode ser positivo ou negativo.

A variação da alcalinidade em um sistema de tratamento de esgoto, em virtude da nitrificação, é calculada a partir da concentração de amônia nitrificada. Esta concentração é igual à diferença entre a concentração do NTK afluente $\left(\mathrm{N}_{\mathrm{ka}}\right)$ e a soma das 
concentrações do NTK efluente $\left(\mathrm{N}_{\mathrm{ke}}\right)$ e aquela necessária para a produção de lodo $\left(\mathrm{N}_{l}\right)$ Equação 5.6.

$\mathrm{N}_{\mathrm{c}}=\mathrm{N}_{\mathrm{ka}}-\mathrm{N}_{\mathrm{ke}}-\mathrm{N}_{\mathrm{l}}$

Onde:

$\mathrm{N}_{c}$ : concentração de amônia afluente nitrificada no sistema (mgN L ${ }^{-1}$ )

O efeito da nitrificação sobre a alcalinidade pode ser expressa como (Equação 5.7):

$\Delta$ alc $_{\mathrm{n}}=-7,14 \mathrm{~N}_{\mathrm{c}}=-7,14\left(\mathrm{~N}_{\mathrm{ka}}-\mathrm{N}_{\mathrm{ke}}-\mathrm{N}_{\mathrm{l}}\right)$

Para a desnitrificação, a variação da alcalinidade depende da concentração do nitrato removido do sistema. Essa concentração pode ser representada pela Equação 5.8.

$\Delta \mathrm{N}_{\mathrm{d}}=\mathrm{N}_{\mathrm{na}}+\mathrm{N}_{\mathrm{c}}-\mathrm{N}_{\mathrm{ne}}$

Portanto, a variação da alcalinidade ocasionada pela desnitrificação pode ser expressa como (Equação 5.9):

$\Delta$ alc $_{\mathrm{d}}=3,57 \Delta \mathrm{Nd}=3,57\left(\mathrm{~N}_{\mathrm{na}}+\mathrm{N}_{\mathrm{ka}}-\mathrm{N}_{\mathrm{ke}}-\mathrm{N}_{\mathrm{l}}-\mathrm{N}_{\mathrm{ne}}\right)$

Por fim, a variação total da alcalinidade no sistema será igual à soma dos efeitos da amonificação, nitrificação e desnitrificação (Equação 5.10)

$\Delta$ alc $_{\mathrm{t}}=\Delta \mathrm{alca}_{\mathrm{m}}+\Delta \mathrm{alc}_{\mathrm{n}}+\Delta \mathrm{alc}_{\mathrm{d}}=3,57\left(\mathrm{~N}_{\mathrm{oa}}-\mathrm{N}_{\mathrm{oe}}-\mathrm{N}_{\mathrm{l}}\right)-7,14\left(\mathrm{~N}_{\mathrm{ka}}-\mathrm{N}_{\mathrm{ke}}-\mathrm{N}_{\mathrm{l}}\right)+3,57\left(\mathrm{~N}_{\mathrm{na}}+\mathrm{N}_{\mathrm{ka}}-\mathrm{N}_{\mathrm{ke}}-\mathrm{N}_{l}-\mathrm{N}_{\mathrm{ne}}\right)$

(Eq. 5.10)

Considerando que a concentração do NTK $\left(N_{k}\right)$ é a soma da concentração de nitrogênio orgânico $\left(N_{o}\right)$ e amoniacal $\left(N_{a}\right)$, a Equação 5.10 se simplifica para Equação 5.11:

$\Delta$ alct $=-3,57\left(N_{\text {aa }}-N_{n a}-N_{a e}+N_{n e}\right)=3,57\left(\Delta N_{a}-\Delta N_{n}\right)$

Onde:

$\Delta N a$ : variação da concentração de amônia no sistema

$\Delta \mathrm{Nn}$ : variação da concentração de nitrato no sistema

Os parâmetros à direita da Equação 5.11podem ser determinados experimentalmente usando-se testes padronizados. Portanto, é possível calcular teoricamente qual a variação da alcalinidade causada pelo efeito estequiométrico combinado de amonificação, nitrificação e desnitrificação. Este valor pode ser, posteriormente, comparado com a 
variação observada da alcalinidade. Na Figura 3.10 se observam resultados de variação teórica e experimental da alcalinidade, mostrando que há uma boa correlação (VAN HAANDEL \& MARAIS 1999).

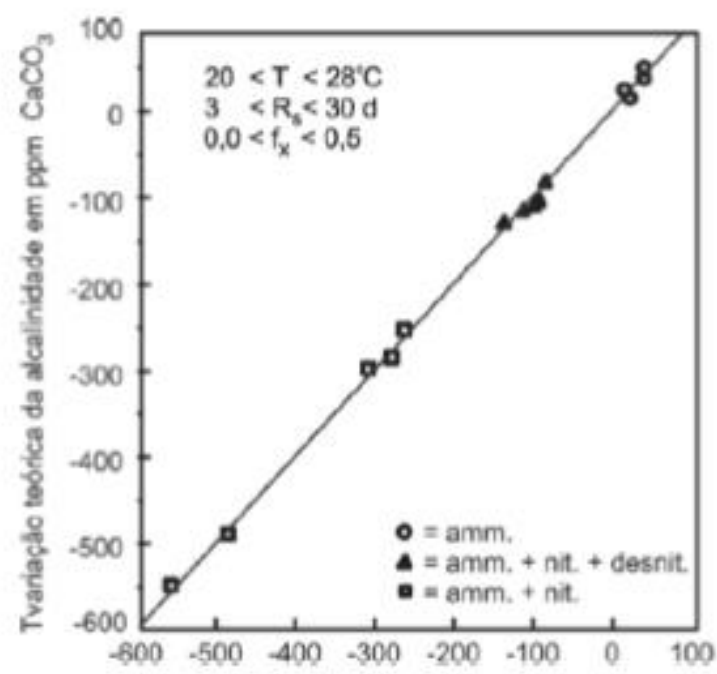

Figura 3.10:Variação teórica versus variação experimental da alcalinidade para diferentes sistemas de lodo ativado

Fonte: VAN HAANDEL e MARAIS (1999)

\subsection{Sistema de Aeração}

Como em qualquer tecnologia que emprega processo aeróbio para o tratamento de esgotos, no MBBR/IFAS deve-se também manter disponibilidade de oxigênio segundo quantidade requerida pelos microrganismos decompositores. Da mesma forma, o sistema de aeração deve prover energia suficiente para manter em mistura da massa líquida em suspensão e permitir o processo de floculação biológica.

Em princípio, ressalta-se no entanto, que em função de especificidades do processo MBBR/IFAS, este venha requerer do sistema de aeração a provisão de maior quantidade de energia. De fato, primeiramente, o processo, ao manter maior quantidade de biomassa no reator biológico, tanto aquela em suspensão, como a biomassa aderida, deve requerer o maior fornecimento de OD. Em segundo lugar, o processo é influenciado pelos mecanismos de difusão e de transporte de massa de oxigênio através do biofilme. 
Por fim, a energia necessária para agitação e mistura da massa líquida em suspensão deve também contemplar a movimentação dos meios suporte.

Enquanto $\varnothing D E G A A R D$ et al. (1994) recomendam a manutenção de concentração de OD compreendida entre 2 e $5 \mathrm{mg} \mathrm{L}^{-1}$, RUSTEN et al.(1998) sugerem que para nitrificação deve

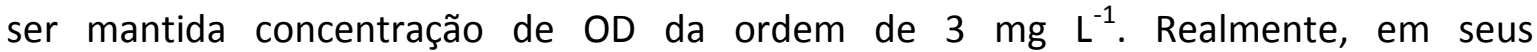
experimentos RUSTEN et al. (1994a) verificaram que a partir da concentração de OD da ordem de 2,5 a $3,0 \mathrm{mg} \mathrm{L}^{-1}$ é que se iniciou o processo de nitrificação

HEM et al. (1994), como mencionado anteriormente, sugerem que a concentração de OD exerça maior interferência sobre o reator MBBR do que o processo de lodos ativados em função da resistência de transporte de massa através do biofilme e verificou que para concentrações de OD da ordem de 4,5 a 5,0 $\mathrm{mg} \mathrm{L}^{-1}$ foram obtidas maiores a taxa de nitrificação.

Estas considerações fazem com que a tecnologia MBBR/IFAS venha requerer a manutenção de concentração de $\mathrm{OD}$ de acordo com valores superiores àqueles praticados convencionalmente pelo processo de lodos ativados. Neste sentido, em princípio, deve ser imposta maior potência de aeração ao processo MBBR/IFAS, o que consequentemente resulta em maior consumo de energia elétrica.

Visando a otimização do processo quanto a este respeito, RUSTEN et al, (1994, 1995, 1997, 1998), HEM et al. (1994) e PASTORELLI et al. (1997) empregaram sistemas de aeração por ar difuso do tipo bolhas médias e grossas. Baseados no princípio da maior eficiência de transferência de oxigênio que os sistemas convencionais de bolhas finas são capazes de promover, os autores preconizaram que as mesmas poderiam ser formadas em função do choque entre bolhas médias ou grossas e os meios suporte em movimentação no tanque de aeração e que existe uma elevação do tempo de retenção das bolhas no meio. Portanto, têm-se um grande impacto sobre o kLa (coeficiente de transferência de oxigênio).

Dentre todos os experimentos anteriormente relatados, são a seguir indicadas as concentrações de OD mantidas nos reatores MBBR: HONG-BIN et al. (2007), entre 2 e 3 $\mathrm{mg} \mathrm{L}^{-1}$; WANG et al. (2006), entre 1,0 e $6,0 \mathrm{mg} \mathrm{L}^{-1}$; LUOSTARINEN et al. (2006), em torno de $9,0 \mathrm{mg} \mathrm{L}^{-1}$; BORGHEI \& HOSSEINI (2004), em torno de $4,5 \mathrm{mg} \mathrm{L}^{-1}$; DAUDE 
\&STEPHENSON (2003), 5,1 $\mathrm{mg} \mathrm{L}^{-1}$ no primeiro reator e $7,6 \mathrm{mg} \mathrm{L}^{-1}$ no segundo reator; ANDREOTTOLA et al. (2003b), em torno de 3,0 mg L-1 ; JAHREN et al. (2002), 2,0 e 3,0 mg L'

${ }^{1}$ e; RUSTEN et al. (1998), 2 mg L ${ }^{-1}$; RUSTEN et al. (1994b), 2,8 a 6,5 $\mathrm{mg} \mathrm{L}^{-1}$.

Por outro lado, BROCH-DUE et al. (1997) em seus experimentos que contemplaram o emprego de reatores MBBR em série, manteve no primeiro reator diferentes concentrações de OD em função das características do efluente, compreendidas em cada caso entre 2,5 e 5,7 $\mathrm{mg} \mathrm{L}^{-1}, 2,5$ e 4,0 $\mathrm{mg} \mathrm{L}^{-1}$ e 3,7 para 5,3 $\mathrm{mg} \mathrm{L}^{-1}$.

Os experimentos de PASTORELLI et al. (1997) demonstraram que a manutenção de concentração de OD inferior a $2 \mathrm{mg} \mathrm{L}^{-1}$ no primeiro dos reatores MBBR em série decorreu em limitada taxa de remoção da DQO filtrada, enquanto nos dois MBBR subsequentes, submetidos a concentração de OD superior a 3,0 mg L'-1, obteve-se a nitrificação do efluente.

RUSTEN et al. (1994a) apesar de não destacar a influência da temperatura para o processo de nitrificação em reatores MBBR, ressaltam que a concentração de OD é o parâmetro mais preponderante.

É importante deixar claro que,em todos esses estudos supracitados, nenhum trabalhou visando a SND. Somente nos trabalhos desenvolvidos por FU et al. (2010) e WANG et al. (2006), como mencionado, visou esse fenômeno, indicando concentração OD em torno de $2,0 \mathrm{mg} \mathrm{L}^{-1}$ para uma excelente remoção de NT.

\subsection{Características do Meio Suporte}

O material frequentemente utilizado para a fabricação dos meios suportes é o polietileno ou polipropileno. A forma cilíndrica é a mais empregada, contendo corrugações externas e divisões internas. O desenvolvimento mais recente da tecnologia aponta para meios suporte na forma de disco.

Segundo PASTORELLI et al. (1997), a densidade do meio suporte deve ser da ordem de $1 \mathrm{~g}$ $\mathrm{cm}^{-3}$. Os desenvolvimentos de $\varnothing \mathrm{DEGAARD}$ et al. (1994) sempre utilizaram meios suporte cilíndricos com densidade de $0,95 \mathrm{~g} \mathrm{~cm}^{-3}$. 
As diferentes configurações dos meios suporte resultam em diferentes áreas de contato, as quais podem ainda apresentar maior ou menor potencial para aderência de biomassa em função do arranjo e desenho geométrico da peça. Assim, os meios suporte podem ser caracterizados tanto em função da superfície total disponível, quanto em função de uma parcela desta, a qual corresponderia à área de efetiva aderência de biomassa.

A movimentação e o choque entre os meios suporte mantidos no interior do reator MBBR/IFAS fazem com que as faces externas dos mesmos sejam continuamente sujeitas a perda de eventual biomassa aderida. Entende-se que neste caso, a configuração da superfície externa do meio suporte não somente influencie a adesão de biomassa assim como a perda da mesma; superfícies mais corrugadas e acidentadas tendem a conter nichos que proporcionem a maior aglomeração de organismos e que dificultem o cisalhamento de biomassa aderida. Neste contexto, a área de efetiva aderência de biomassa tende a ser igual à área total disponível, quanto maior for a capacidade de retenção de biomassa que o meio suporte apresentar.

Essa tecnologia tem a Área Superficial Específica como principal parâmetro de referência e especificação do meio suporte empregado. É dada pela razão entre a totalidade da área de meio suporte e o volume por ele ocupado, considerado o devido empolamento das peças em função da disposição natural das mesmas em um dado volume.

Deve ainda o conceito de Área Superficial Específica contemplar somente as superfícies do meio suporte, nas quais efetivamente ocorrem a aderência de biomassa. Neste sentido a totalidade de área superficial disponível para a efetiva aderência de biomassa em um reator MBBR/IFAS corresponde ao produto entre a Área Superficial Específica (considerando somente a superfície de efetiva aderência) e a quantidade de meios suporte efetivamente contida por unidade de volume igual a $1 \mathrm{~m}^{3}$.

A importância da correta interpretação do conceito de Área Superficial Específica deve-se ao fato de que a quantidade de meio suporte introduzida no reator biológico é determinada em função da efetiva quantidade de biomassa aderida que se pretende manter no processo. 
De fato, enquanto alguns autores sugerem que a área externa do meio suporte seja também contabilizada, outros sugerem somente a área para potencial crescimento de biofilme, enquanto outros sequer mencionam qual critério estabeleceram.

É usual referir-se à quantidade de peças a ser adicionada ao reator como um percentual do seu volume. Segundo estudos de ØDEGAARD et al. (1993); ØDEGAARD et al.(1994); RUSTEN et al.(1998); ANDREOTTOLA et al. (2000) e outros autores, a quantidade de meio suporte no reator MBBR deve ser compreendida entre 40 e $70 \%$ do seu volume. Já a NBR 12.209 , recomenda porcentagens de meio suporte compreendidas de 30 até $60 \%$.

\subsection{Características da Biomassa}

Como anteriormente descrito, o processo MBBR/IFAS consiste em um reator biológico híbrido, no qual organismos decompositores são mantidos tanto em suspensão na massa líquida, como também aderidos ao meio suporte.

Também fora evidenciado que a aplicabilidade do processo ocorre tanto para o caso de novas ETEs, assim como para o caso de adaptações no processo de lodos ativados de ETES existentes. É, portanto muito clara e natural a analogia entre o processo MBBR/IFAS e o processo de lodos ativados.

Consequentemente, são comuns a ambos os processos os mesmos parâmetros de projeto e de controle. A única particularidade reside no fato de que a biomassa responsável pela decomposição de substratos não é somente devida aos microrganismos em suspensão como também aqueles aderidos aos meios suporte.

A literatura usualmente caracteriza a biomassa aderida ao meio suporte com base na concentração de Sólidos Totais (ST), com exceção de ANDREOTTOLA et al. (2003b) e HONG-BINet al. (2007), que relacionam os seus experimentos, respectivamente, a concentração de Sólidos em Suspensão Totais(SST) e Sólidos em Suspensão Voláteis (SSV). Entende-se que em qualquer um dos casos, em se tratando do processo MBBR/IFAS, deverão ser consideradas tanto as concentrações de sólidos aderidos ao meio suporte assim como aquelas em suspensão, cujo somatório representaria a totalidade da biomassa presente no reator. 
Apesar desta particularidade, é também usual a literatura somente fazer referência à quantidade de biomassa presente no processo MBBR/IFAS com base na massa de sólidos aderidos por área superficial de meio suporte, expressa em $\mathrm{g} \mathrm{m}^{-2}$.Todavia, atualmente, uma terminologia vem sendo adotada para expressar a biomassa aderida, a Densidade de Biofilme Aderida - DBA, que nada mais é do que a massa desólidos (SST ouSSV)aderida representada em $\mathrm{mg} \mathrm{L}^{-1}$.

De fato,MARTíN-PASCUALet al. (2015) trabalharam com um IFAS precedendo um MBR a fim de availiar o efeito do volume de meios suporte, a quantidade de biomassa em suspensão, o TDH e a temperatura no comportamento da biomassa aderida. Eles obtiveram valores de DBA variando de $4.403 \pm 188 \mathrm{mg} \mathrm{SSV} \mathrm{L}^{-1}$ até $5.844 \pm 268 \mathrm{mg} \mathrm{SSV} \mathrm{L}^{-1}$. De maneira geral, a DBA foi mais elevada com a diminuição do TDH e o aumento da biomassa em suspensão e, quanto menor foi o volume de meios suporte. Isto porque quanto mais peças no reator, maior o choque entre elas, favorecendo assim o desprendimento da biomassa aderida.

Em outro estudo realizado por MARTín-PASCUALet al. (2014), no qual visavam analisar a variação do TDHno comportamente da biomassa heterotrófica,alcançaram valores de DBA de $2.145 \pm 348 \mathrm{mg} \mathrm{SSV} \mathrm{L}^{-1}$ a $3.716 \pm 404 \mathrm{mg} \mathrm{SSV} \mathrm{L}^{-1}$. Salienta-se que a unidade piloto era a mesma do trabalho supracitado (Martín-Pascual et al. 2015), e que os maiores valores foram obtidos foi quando o sistema trabalhou em uma temperatura e TDH mais elevado $\left(20,6 \pm 1,5^{\circ} \mathrm{C}\right.$ e $\left.24 \mathrm{~h}\right)$.

LEYVA-DÍAZet al.(2013)a empregaram neste estudo três diferentes sistemas trabalhando em paralelo,formados por um reator aeróbio, seguido por um anóxico, dois aeróbios e um reator com membrada (MBR); sendo que no primeiro sistema somente havia biomassa em suspensão, no segundo todos reatores continham meios suporte (MBBRs) e no terceiro somente o reator anóxico não possuía meios suporte. A DBA atingida nos reatores MBBR aeróbios em ambos os sistemas foi de $1.035 \pm 345 \mathrm{mg} \mathrm{SSV} \mathrm{L}^{-1}$, e de $675 \pm$ $175 \mathrm{mg} \mathrm{SSV} \mathrm{L}^{-1}$ no reator MBBR anóxico no segundo sistema. Os autores indicaram que a baixa DBA no reator anóxico foi devido ao sistema de agitação.

LEYVA-DÍAZ et al.(2013)b realizaram um outro trabalho com um sistema piloto constituído por um reator IFAS (volume de 358 L) seguido por um MBR (volume de $87 \mathrm{~L}$ ) e um similar em escala de bancada com volumes de $24 \mathrm{~L}$ e $4,32 \mathrm{~L}$, respectivamete, 
objetivando avaliar influência dessa escala de tamanho nos resultados. O valor de DBA para o sistema piloto foi de $3.606 \pm 288 \mathrm{mg} \mathrm{SSV} \mathrm{L}^{-1}$ e para o sistema de bancada igual a $867 \pm 309 \mathrm{mg} \mathrm{SSV} \mathrm{L}^{-1}$. Tal diferença de resultado foi relacionada a aeração do sistema de bancada, na qual ocasinou elavada colisão dos meios suporte com as paredes do reator, causando maior desprendimento da biomassa aderida em comparação com o sistema piloto, isso mantendo uma mesma concentração de OD. Este fenômeno é denominado Efeito Parede (Wall Effect), e possui mais predominância em sistemas com menor escala.

Experimento conduzido por MARTÍN-PASCUALet al. (2012), cujo sistemas eram formado por três MBBR em paralelo (cada MBBR com volume de $3 \mathrm{~L}$ ), sendo introduzido diferentes meios suporte em cada um a fim de avaliar sua influência na cinética de remoção da matéria orgânica. Ademais, foi variado o TDH e o volume de meios suporte. Observou-se que, de modo geral, a DBA variou de $1.500 \mathrm{mg} \mathrm{SSV} \mathrm{L}^{-1}$ a $2.700 \mathrm{mg} \mathrm{SSV} \mathrm{L}^{-1}$ dependendo do TDH e do volume de meios suporte.

Já ZHANG et al.(2013), avaliaram as caracteristicas do biofilme e a performace da nitrificação em cinco reatores MBBR em paralelo de escala laboratorial com $45 \mathrm{~L}$ cada, utilizando dois tipos de meios suporte, uma razão de $50 \%$ de enchimento e variando a carga de nitrogênio amoniacal aplicada.Em relação a biomassa aderida, obtiveram valores de $0,58 \mathrm{~g} \mathrm{SV} \mathrm{m}^{-2}$ a $1,1 \mathrm{~g} \mathrm{SV} \mathrm{m}^{-2}$. Ressalta-se que nesse experimento praticamente não foi aplicada nenhum carga orgânica.

MINEGATTI(2008), trabalhando com um reator IFAS, em escala piloto, obteve massa aderida igual a 15,6 $\mathrm{g} \mathrm{SSV} \mathrm{m}^{-2}$, utilizando meio suporte com Área Superficial Específica de $600 \mathrm{~m}^{2} \mathrm{~m}^{-3}$ e apenas $20 \%$ do volume do reator.

HONG-BINet al. (2007), utilizando dois reatores MBBR em série, em escala laboratorial, obtiveram no primeiro reator massa aderida equivalente a $5 \mathrm{~g} \mathrm{SSV} \mathrm{m}^{-2}$, considerando o meio suporte com Área Superficial Específica de $614 \mathrm{~m}^{2} \mathrm{~m}^{-3}$ e a ocupação de $60 \%$ do volume do reator.

LUOSTARINEN et al. (2006) trabalharam com reator MBBR, em escala laboratorial, com volume de 2 litros, meio suporte com Área Superficial Específica de $500 \mathrm{~m}^{2} \mathrm{~m}^{-3}$ e ocupação de 50 \% do volume do reator. Para o sistema que era precedido por um reator 
UASB, obtiveram-se massas aderidas aos meios suporte compreendidas entre 26 e $44 \mathrm{~g}$ ST $\mathrm{m}^{-2}$.

ANDREOTTOLA et al. (2003b) investigaram o processo MBBR para o tratamento de efluentes de restaurantes e sanitários localizados nos Alpes italianos. Segundo volume de 2,4 $\mathrm{m}^{3}$, meio suporte com Área Superficial Específica de $500 \mathrm{~m}^{2} \mathrm{~m}^{-3}$, ocupação de $42 \%$ do volume do reator, resultando em área superficial disponível por volume de reator de 210

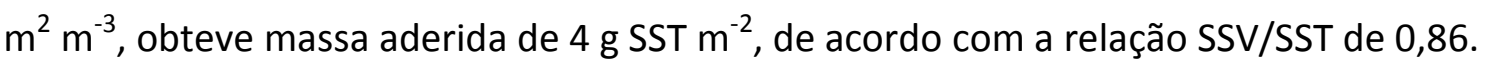

JAHREN et al. (2002) trabalharam com um MBBR em escala de bancada, tratando efluente de indústria de papel e celulose. Para a razão entre o volume do meio suporte e o volume do reator de $58 \%$ e Área Superficial Específica de $500 \mathrm{~m}^{2} \mathrm{~m}^{-3}$, obtiveram-se concentração total de sólidos no reator compreendida entre 1.400 e $1.900 \mathrm{mg} \mathrm{SSV} \mathrm{L}^{-1}$, sendo a massa aderida equivalente a $85 \%$ destes, e correspondente à relação entre SSV/SST da ordem de 0,91. Ressalta-se que neste caso o aparato experimental não possuía decantador secundário.

Experimento conduzido por RUSTEN et al. (1998), cujo sistema consistia em um decantador primário seguido por reator $M B B R$, tanque de reaeração, RBC e por fim, decantador secundário, mantiveram concentração de sólidos totais no reator MBBR da ordem de $4.250 \mathrm{mg} \mathrm{ST} \mathrm{L} \mathrm{L}^{-1}$, para o percentual volumétrico de meio suporte de $48 \%$, o qual correspondeu à área superficial disponível por volume de reator de $238 \mathrm{~m}^{2} \mathrm{~m}^{-3}$.

Visando a remoção de nutrientes, RUSTEN et al. (1994a) adaptaram ao processo MBBR uma ETE existente em Bekkelaget - Noruega, cujo processo consistia em tratamento físico-químico seguido pelo processo de lodos ativados. Com volume total de $568 \mathrm{~m}^{3} \mathrm{de}$ reator, mantiveram concentração média de $4.000 \mathrm{mg} \mathrm{ST} \mathrm{L}^{-1}$ em cada um dos quatro reatores MBBR sequenciais, sendo que somente $2 \%$ da massa de sólidos era mantida em suspensão. Neste caso, o reator MBBR continha meios suporte com Área Superficial Específica de $300 \mathrm{~m}^{2} \mathrm{~m}^{-3}$, de acordo com percentual de enchimento equivalente a $60 \%$ do volume do reator.

Experimento de RUSTEN et al. (1994b) tratando efluentes de indústrias de celulose e papel foi constituído por dois MBBR em série, com volume de $0,5 \mathrm{~m}^{3}$ cada reator, seguido por decantação secundária. Para o percentual de enchimento de meio suporte de $70 \%$, 
obtiveram-se no primeiro reator, concentração de biomassa aderida equivalente a 2.300 mg ST L ${ }^{-1}$ e de $5100 \mathrm{mg} \mathrm{ST} \mathrm{L} \mathrm{L}^{-1}$ de biomassa em suspensão.

\subsection{Emissão de Óxido Nitroso}

O Óxido Nitroso $\left(\mathrm{N}_{2} \mathrm{O}\right)$ é naturalmente produzido por uma variedade de microrganismos aeróbios e anaeróbios, tanto em meio aquático quanto terrestre. Contudo, as atividades humanas estão cada vez mais alterando o ciclo global no nitrogênio e, consequentemente, elevando a emissão de óxido nitroso. Esta questão é bastante problemática devido ao $\mathrm{N}_{2} \mathrm{O}$ possuir cerca de 300 vezes maior potencial de aquecimento global quando comparado ao dióxido de carbono $\left(\mathrm{CO}_{2}\right)$. Além disso, o $\mathrm{N}_{2} \mathrm{O}$ contribui indiretamente para o consumo do ozônio $\left(\mathrm{O}_{3}\right)$ estratosférico, gás que protege a superfície do planeta de uma maior incidência de radiação ultravioleta (IPCC, 2006; MCELROY, 2002).

Especialmente, a produção de $\mathrm{N}_{2} \mathrm{O}$ em sistemas de tratamento de esgotos está associada aos processos microbiológicos de nitrificação e desnitrificação (KAMPSCHREUR et. al 2009). No caso de ETE com sistemas de lodos ativados, apesar de, em escala real, ainda não haver um completo entendimento dos mecanismos que levam à emissão de $\mathrm{N}_{2} \mathrm{O}$, CZEPIELet. al(1995) reportaram que $91 \%$ do total das emissões de $\mathrm{N}_{2} \mathrm{O}$ de uma ETE de lodos ativados no nordeste dos Estados Unidos foram oriundos do tanque de aeração. BROTTOet. al(2010) encontraram resultado semelhante em uma ETE de lodos ativados localizada no sudeste do Brasil. Em estudo realizado em 12 ETE localizadas nos EUA, AHNet. al(2010) indicaram que elevadas concentrações de amônio $\left(\mathrm{NH}_{4}{ }^{+}\right)$, nitrito $\left(\mathrm{NO}_{2}{ }^{-}\right)$e oxigênio dissolvido (OD) no tanque de aeração estão positivamente correlacionados com as emissões de $\mathrm{N}_{2} \mathrm{O}$.

Por meio de estudo realizado em escala piloto, LOTITOet. al(2012) complementam que a conversão de $\mathrm{N}-\mathrm{NH}_{4}{ }^{+}$a $\mathrm{N}_{2} \mathrm{O}$ está fortemente relacionada a parâmetros operacionais, tais como concentração de NT afluente, idade do lodo e concentração de OD.

De qualquer forma, nesses poucos estudos realizados, os resultados obtidos são bastantes discrepantes (KAMPSCHREUR et al. 2009). As Diretrizes de 2006 do IPCC para Inventários Nacionais de Gases do Efeito Estufa propõem como fator de emissão 3,2 (2-8) 
g N $\mathrm{N}_{2} \mathrm{O}$ por pessoa ao ano para o caso de estações de tratamento de esgoto com processos de nitrificação e desnitrificação controlados (IPCC, 2006).Entretanto, a United States Environmental Protection Agency (US-EPA) adota o FE 7,0 g N $\mathrm{g}_{2} \mathrm{O}$ pessoa $^{-1}$ ano $^{-1}$ para o caso de ETE com processos de desnitrificação intencional, e o $\mathrm{FE} \mathrm{3,2} \mathrm{g} \mathrm{N}_{2} \mathrm{O}$ pessoa ${ }^{-1}$ ano $^{-1}$ para ETE com processos de desnitrificação não intencional.

Outros estudos encontrados na literatura indicam que a principal condição operacional que ocasiona a elevada produção de $\mathrm{N}_{2} \mathrm{O}$ são: concentração de $\mathrm{OD} \leq 1,0 \mathrm{mg} \mathrm{L}^{-1}$, elevada concentração de Nitrito e baixa relação $\mathrm{DQO} / \mathrm{N}$; isto em sistemas de lodos ativados (FOLEY et al. 2010; TALLEC et al. 2006; TALLEC et al. 2008; KAMPSCHREUR, et al. 2008). 


\section{MATERIAL E MÉTODOS}

A Figura 4.1 ilustra, resumidamente, a cronologia de todo experimento, destacando as fases operacionais e os principais eventos extraordinários ocorridos durante a pesquisa, que serão minuciosamente detalhados nos itens seguintes. 


\begin{tabular}{|c|c|c|c|c|c|c|c|c|c|c|c|c|c|c|c|c|c|}
\hline Reator & Var. & \multicolumn{16}{|c|}{ LINHA DO TEMPO - CRONOLOGIA DO EXPERIMENTO } \\
\hline \multirow{3}{*}{ IFAS 1} & EFL. & \multicolumn{16}{|c|}{ Esgoto Sanitário } \\
\hline & OD & 4,5 & \multirow{2}{*}{ (13) } & \multirow{2}{*}{\multicolumn{2}{|c|}{$\frac{2,4}{5,5}$}} & \multirow{2}{*}{ (18) } & \multicolumn{5}{|c|}{2,0} & \multirow{2}{*}{ (18) } & \multicolumn{4}{|c|}{1,5} & \multirow{2}{*}{ (26) } \\
\hline & TDH & 5,5 & & & & & \multicolumn{5}{|c|}{11} & & \multicolumn{4}{|c|}{11} & \\
\hline \multirow{3}{*}{ IFAS 2} & EFL. & & & & & & & & \multicolumn{4}{|c|}{ Esgoto Sanitário } & \multicolumn{5}{|c|}{ Efluente Sintético } \\
\hline & OD & & & & & & & & \multicolumn{3}{|c|}{1,0} & \multirow{2}{*}{ (12) } & \multicolumn{4}{|c|}{1,0} & \multirow{2}{*}{$(21)$} \\
\hline & TDH & & & & & & & & \multicolumn{3}{|c|}{11} & & \multicolumn{4}{|c|}{11} & \\
\hline \multirow{3}{*}{ IFAS 3} & EFL. & & & & & & & & \multicolumn{4}{|c|}{ Esgoto Sanitário } & \multicolumn{5}{|c|}{ Efluente Sintético } \\
\hline & OD & & & & & & & & \multicolumn{3}{|c|}{1,5} & \multirow{2}{*}{ (12) } & \multicolumn{3}{|c|}{1,5} & & \multirow{2}{*}{ (21) } \\
\hline & TDH & & & & & & & & \multicolumn{3}{|c|}{11} & & & & & & \\
\hline FA & & Fase & $5,5 \mathrm{~h}$ & Fas & $\begin{array}{l}\text { L.2 TD } \\
\text { OD } 2 \text {, }\end{array}$ & $5,5 \mathrm{~h}$ & & 1 or & $\begin{array}{l}e \\
0-2\end{array}$ & $\begin{array}{l}\text { DH } 1 \\
1,0-3\end{array}$ & 1,5 & & $1 \mathrm{ESO}$ & $\begin{array}{l}\text { Fas } \\
L, 5-2\end{array}$ & $\begin{array}{l}.2 \mathrm{~T} \\
\mathrm{JT} O \mathrm{OD}\end{array}$ & $\begin{array}{c}11 \mathrm{~h} \\
-3 \mathrm{SIN}\end{array}$ & $O D 1,5$ \\
\hline Al & & & 20 & & & & & & & & & 2015 & & & & & \\
\hline $\mathbf{M}$ & & 07 & 09 & 10 & 11 & 12 & 01 & 02 & 03 & 04 & 05 & 06 & 07 & 08 & 09 & 10 & 11 \\
\hline $\begin{array}{r}\text { PLANEJ } f \\
\text { OB }\end{array}$ & $\begin{array}{l}\text { IENTO E } \\
\text { IIVOS } \times A\end{array}$ & $\begin{array}{l}\text { IIMENT } \\
\text { RATO }\end{array}$ & & REVIS & USP 1 & $12 \uparrow$ & & & $\begin{array}{l}05 \\
\text { TIDA }\end{array}$ & & & & & & PAR & ETROS & INÉTICOS \\
\hline & & & ADE IF & S 1 , & & & & & & & & & & VIDAD & & & $\begin{array}{l}19,20 \\
26,27\end{array}$ \\
\hline & & & $\mathrm{ACÇÃC}$ & IFAS & & & & & & & & & & & 51 & & \\
\hline & & & ORAT & RIO & & & & & & & & $\begin{array}{l}27 \\
\mathrm{~K}\end{array}$ & & & IBADC & $\begin{array}{l}18 \\
\text { DBO }\end{array}$ & $\begin{array}{l}109 \\
\text { MUFLA }\end{array}$ \\
\hline
\end{tabular}

Figura 4.1: Cronologia do Experimento 


\subsection{Centro Experimental de Saneamento Ambiental da Universidade Federal do Rio}

de Janeiro - CESA/UFRJ

A unidade experimental de pesquisa, objeto do presente trabalho, é uma das unidades que compõem o Centro Experimental de Saneamento Ambiental da Universidade Federal do Rio de Janeiro - CESA/UFRJ.

O CESA/UFRJ tem como missão atender os objetivos acadêmicos de ensino e pesquisa dos cursos de graduação e pós-graduação da UFRJ voltados à engenharia de recursos hídricos, sanitária e ambiental. Consiste em uma central de operações, processos e tecnologias dotada das seguintes unidades de tratamento de esgotos: grade de barras, desarenador por gravidade, decantação primária convencional, decantação primária quimicamente assistida, reator UASB, tanque séptico, filtro anaeróbio, filtro biológico percolador, lodos ativados, filtro de areia, lagoa aerada, lagoa de sedimentação, lagoa facultativa, lagoa de maturação, MBBR/IFAS, digestores de lodo; além simulador de águas urbanas, unidade de reúso de água de chuva, entre outros. A Figura 4.2 apresenta a vista geral do CESA/UFRJ.

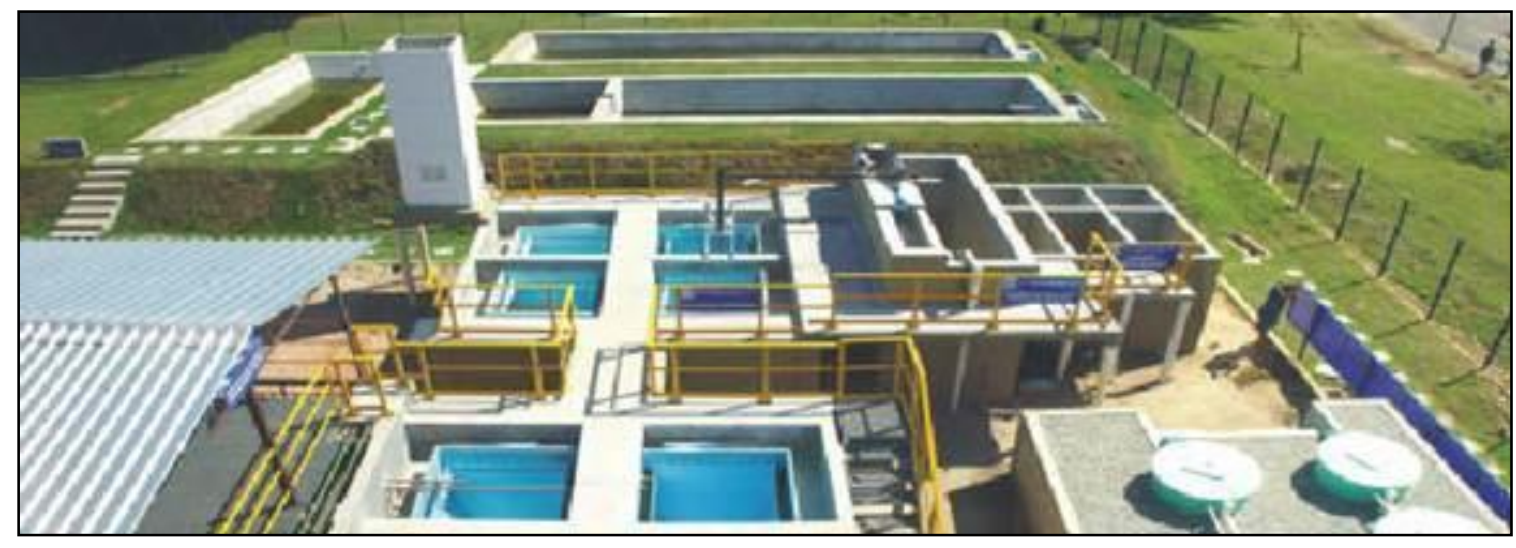

Figura 4.2: Vista geral do CESA/UFRJ

O CESA/UFRJ localiza-se na Cidade Universitária (Ilha do Fundão), próximo à estação elevatória de esgotos do Fundão, unidade responsável pela coleta e recalque de todo o esgoto gerado no campus da UFRJ para a ETE Penha.

Por meio de uma bomba submersa instalada no canal de grades da estação elevatória do Fundão, parte dos esgotos gerados na Cidade Universitária - vazão aproximada de 8,0 L s ${ }^{1}$-, é recalcado para o tratamento preliminar do CESA/UFRJ. Salienta-se que, além dessa elevatória, o efluente bruto recalcado até o CESA/UFRJ advém de uma outra elevatória (vazão igual a $2,0 \mathrm{~L} \mathrm{~s}^{-1}$ ), no qual o esgoto é exclusivamente proveniente da vila residencial 
de funcionários da UFRJ. Entretanto, é importante destacar que essa rede de esgoto sofre interferência da maré, ou seja, quando a maré se eleva, as águas da Baia de Guanabara infiltram na rede e, consequentemente, acabam sendo recalcada até o CESA/UFRJ.

De qualquer modo, o esgoto bruto afluente ao CESA/UFRJ é tratado preliminarmente através de uma grade de barras médias e de um desarenador por gravidade, ambas as unidades instaladas em um mesmo canal. O efluente do tratamento preliminar escoa por gravidade para o poço da estação elevatória de esgoto bruto, unidade responsável pelo recalque do esgoto para cada unidade de tratamento do CESA/UFRJ.

\subsection{Características e Condição Operacional do Aparato Experimental}

\subsubsection{Tratamento Preliminar}

O tratamento preliminar do CESA/UFRJ é comum para todos os processos de tratamento nele implantados e como anteriormente citado, é constituído por uma grade de barras do tipo média, estruturada em fibra de vidro, com barras de 1/4" por 2", com espaçamento de 1". Já o desarenador, do tipo canal, apresenta as seguintes dimensões: 0,40 m de largura e 2,5 m de comprimento. A limpeza da grade de barras e do desarenador é realizada manualmente, com frequência semanal. A Figura 4.3 ilustra as unidades do tratamento preliminar.

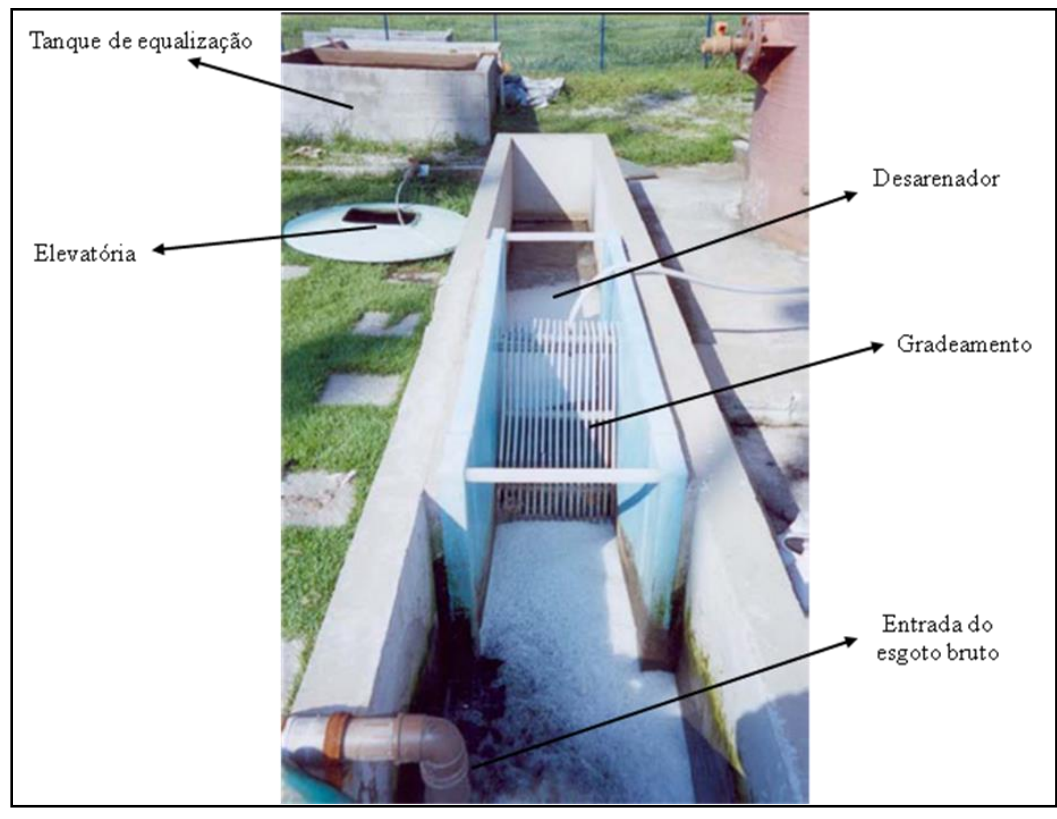

Figura 4.3: Tratamento preliminar 


\subsubsection{Reatores Biológico com Leito Móvel (IFAS) - Unidades Piloto}

A Figura 4.4 ilustra parte do aparato experimental utilizado nesta pesquisa, detalhando o reator IFAS 1 , o qual possui diâmetro de $0,15 \mathrm{~m}$ e profundidade útil de $0,55 \mathrm{~m}$, totalizando volume de aproximadamente $0,01 \mathrm{~m}^{3}$. Ademais, possui uma elevatória de esgoto bruto, um sistema de peneira (Figura 4.5) com abertura 0,84 mm (20 mesh) instalado dentro da elevatória, bomba de recalque, decantador secundário formado por caixa de polipropileno com diâmetro superficial de $0,40 \mathrm{~m}$ por $0,30 \mathrm{~m}$ de profundidade útil (Figura 4.6) e fundo cônico com ângulo de 60, bomba de reciclo de lodo e compressor de ar.

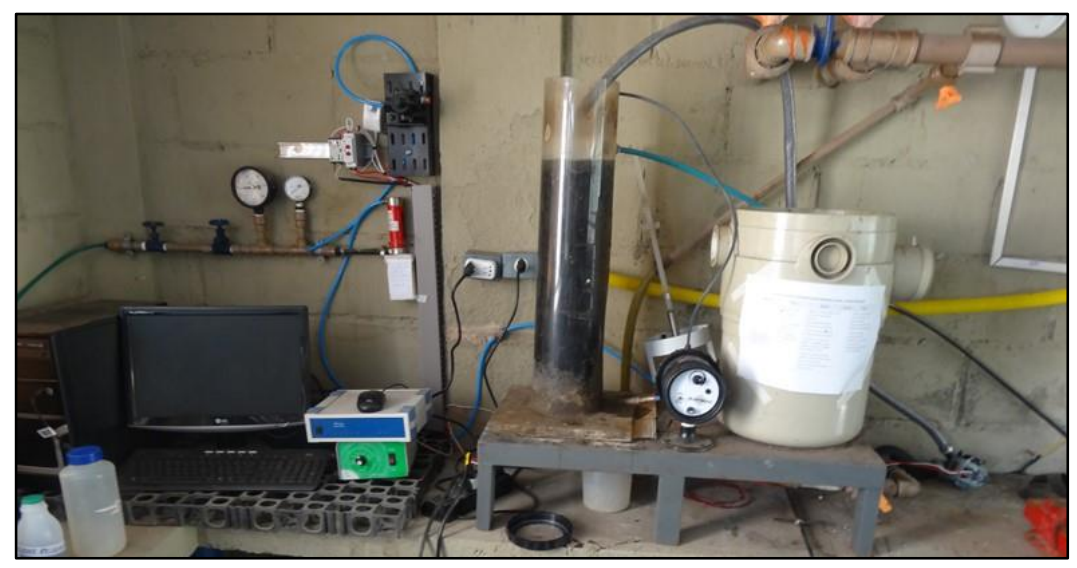

Figura 4.4: Vista do aparato experimental (Reator IFAS 1)

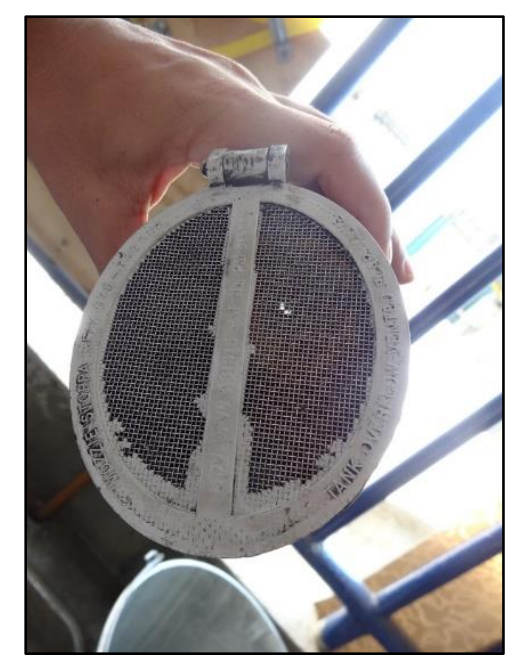

Figura 4.5: Sistema de peneira 


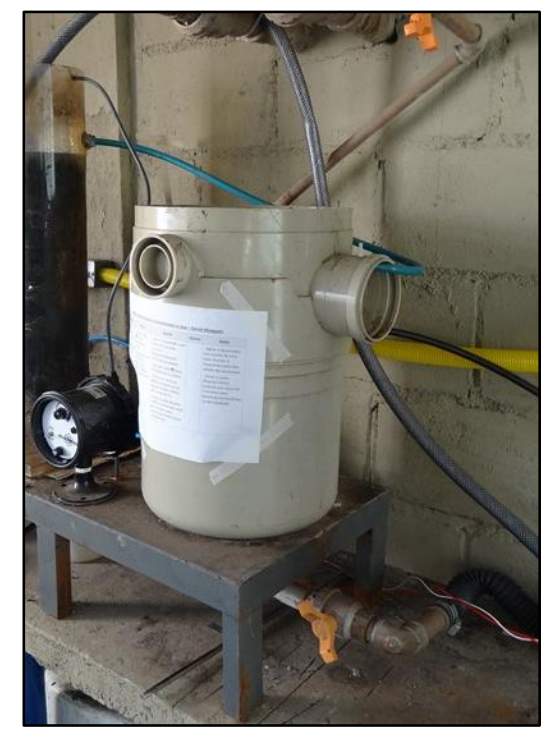

Figura 4.6:Decantador secundário - IFAS 1

Já a Figura4.7 ilustra os reatores IFAS 2 e IFAS 3, os quais foram utilizados na Etapa 2, descrita a seguir, com característicasindicadas na Tabela .4.1.

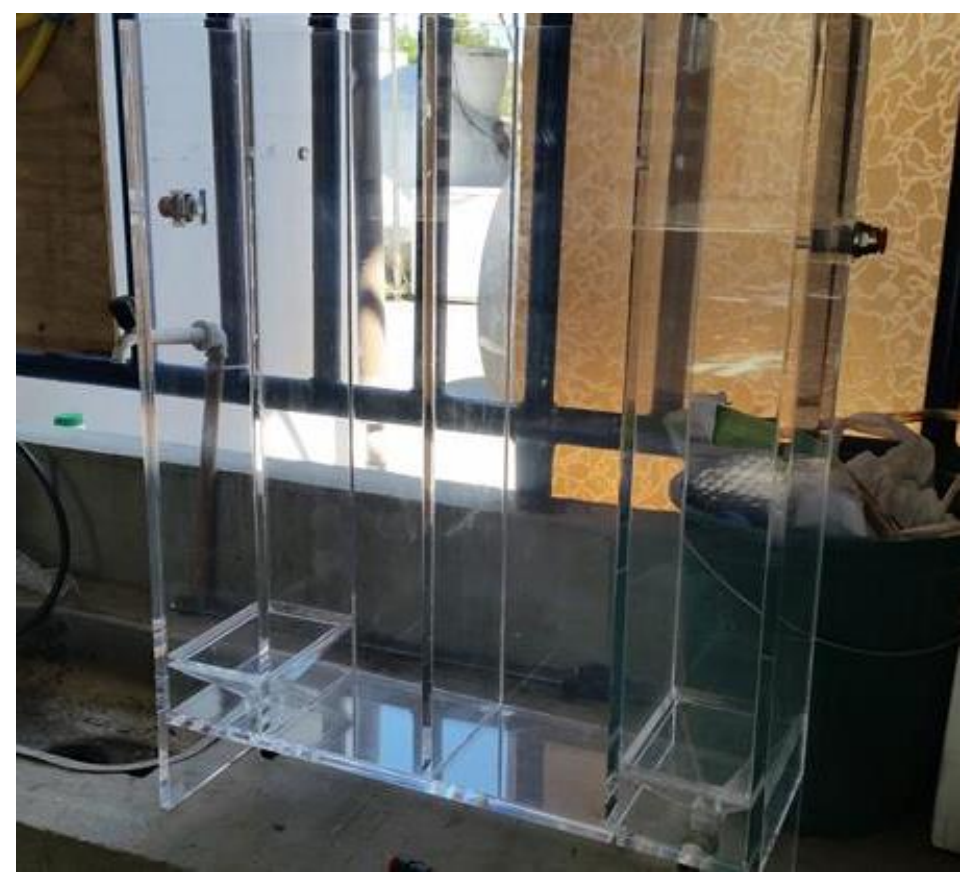

Figura 4.7: Reatores IFAS 2 e IFAS 3 
Tabela 4.1:Características dos reatores IFAS 2 e IFAS 3

\begin{tabular}{cc}
\hline Dados & Dimensões \\
\hline Comprimento & $0,15 \mathrm{~m}$ \\
Largura & $0,15 \mathrm{~m}$ \\
Profundidade & $0,15 \mathrm{~m}$ \\
Volume & $0,0033 \mathrm{~m}^{3}$ \\
\hline
\end{tabular}

Os decantadores secundários dos reatores IFAS 2 e IFAS 3 possuem 0,10m de comprimento, por $0,15 \mathrm{~m}$ de largura e $0,08 \mathrm{~m}$ de profundidade, totalizando aproximadamente $0,0012 \mathrm{~m}^{3}$, estando localizados nas laterais dos reatores.

A recirculação de lodo desde o fundo dos 3 decantadores secundários foram feitas por meio de uma bomba, sendo que a mesma era acionada por cerca de 6 segundos a cada 25 minutos por um sistema de controle (timer), visando manter vazão de recirculação de lodo igual a 100 \% da vazão de entrada. A Figura 4.8 ilustra o timer de controle da bomba.

Outrossim, para o controle mais efetivo dessa vazão, instalou-se um sistema para ajustar velocidade do motor da bomba, podendo assim ajustar criteriosamente a vazão de reciclo.

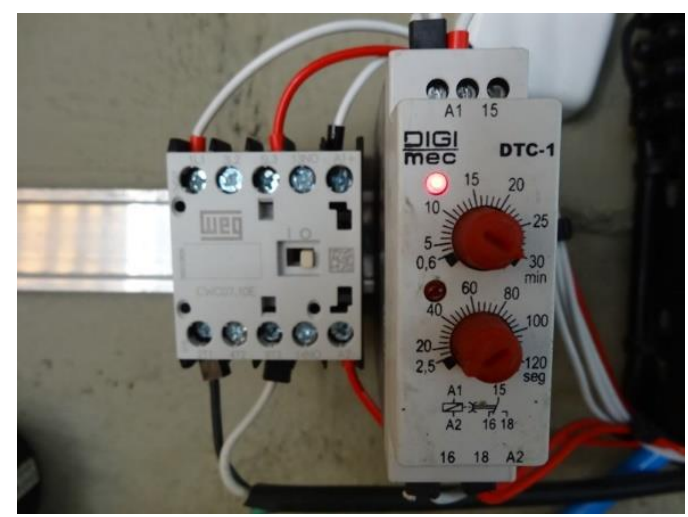

Figura 4.8:Controlador/Timerda bomba de reciclo de lodo

Ainda neste aparato experimental, contou-se com dispositivos de retirada do lodo em excesso para medição volumétrica e coleta de amostras pararealização de análises laboratoriais.

Ressalta-se a não existência de decantador primário precedendo todos os reatores. 


\subsubsection{Sistema de Aeração}

O sistema de aeração consistiu em uma mangueira difusora de bolha média, "tipo de aquário" (Figura 4.9), instalado junto a uma extremidade do fundo do reator.A insuflação de de ar do reator IFAS1 foi promovida por um compressor da marca Schulz, compotência igual a 2,0 HP. Já para os reatores IFAS 2 e IFAS 3, instalou-se em cada reator um compressor de ar para aquário com vazão máxima de 50 L/h (Figura 4.10).

É importante frisar que em todos os reatores foram instalados sistema de controle de ar composto por válvulas e registros, manômetro, termômetro e rotâmetro.

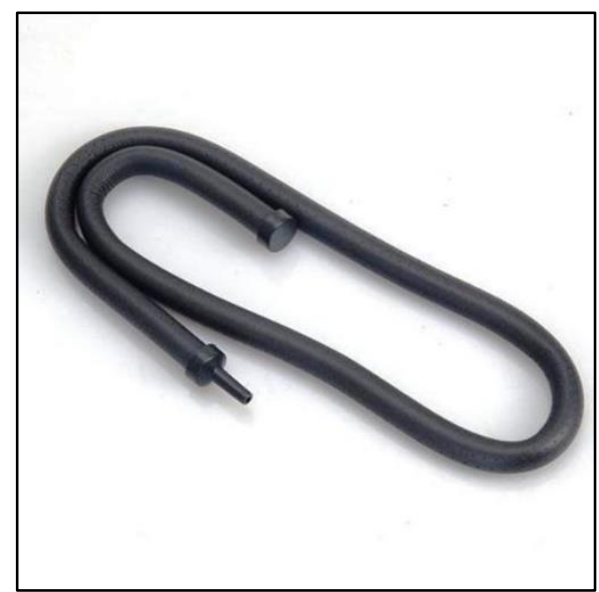

Figura 4.9: Mangueira difusora de bolha média

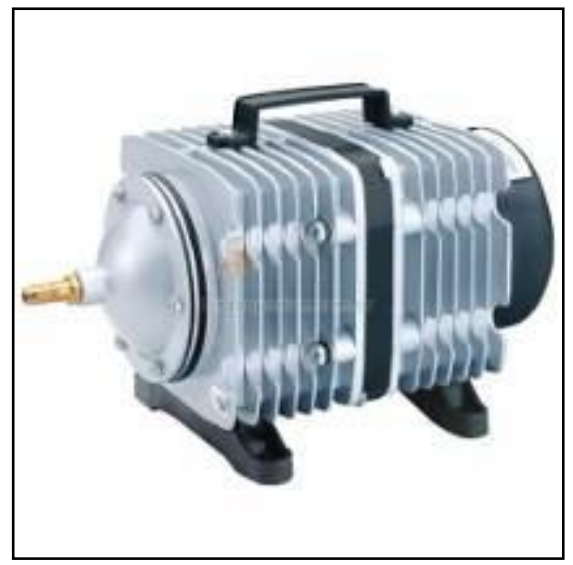

Figura 4.10:Compressor de ar- Reatores IFAS 2 e IFAS 3

Destaca-se que os reatores IFAS 2 e IFAS 3 possuíam um sistema de controle e monitoramento de OD por meio de software ligados aocomputador, o qual aciona o compressor de ar quando a concentração de OD atinge um valor míninoestipulado $(0,8$ $\mathrm{mg} \mathrm{L}^{-1}$ e $\left.1,3 \mathrm{mgL}^{-1}\right)$ e o desliga quando alcança o um valor máximo $\left(1,2 \mathrm{mg} \mathrm{L}^{-1}\right.$ e $\left.1,7 \mathrm{mgL}^{-1}\right)$. Foi possível assim controlar a introdução de oxigênio nos reatores,visando manter a 
concentração média proposta no estudo. A Figura 4.11 exemplifica a tela do computador demonstrando a linha média de OD no reator IFAS 2 (OD médio igual a 1,0 $\mathrm{mg} \mathrm{L}^{-1}$ ).

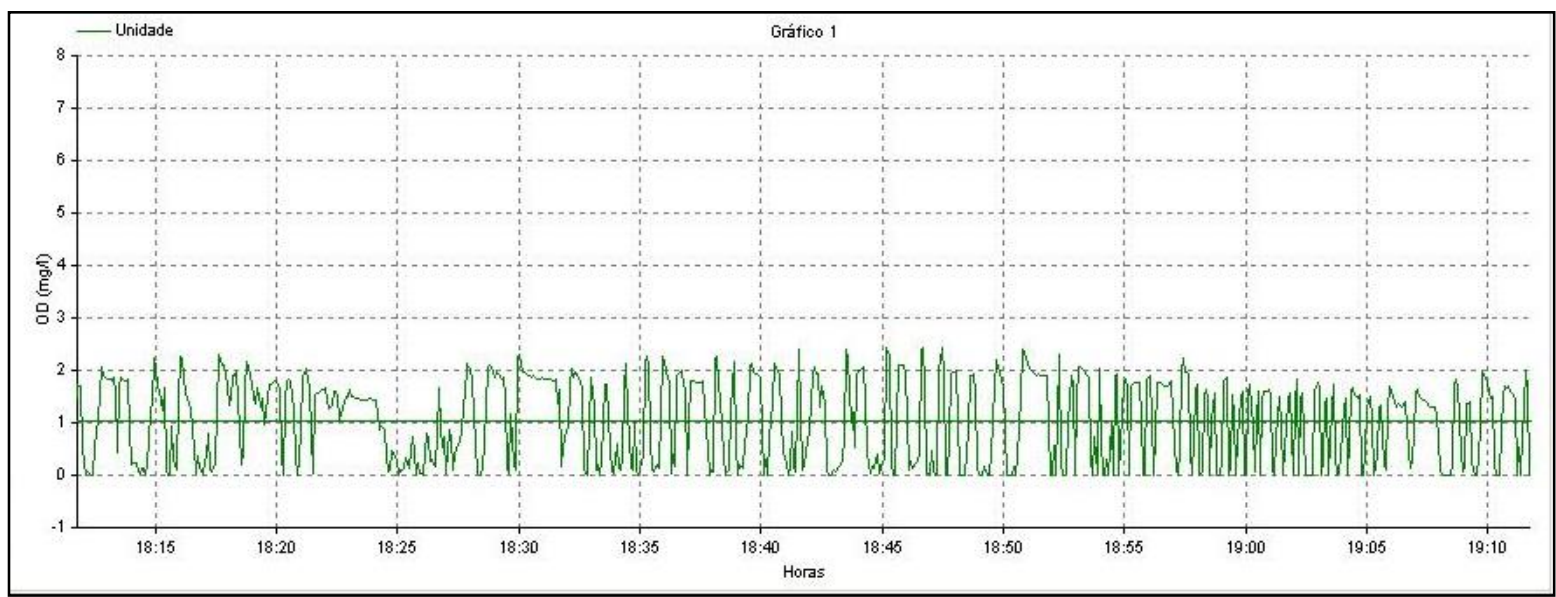

Figura 4.11: Tela do computador indicando OD médio

Outro ponto importante que merece ser frisadoé que uma vez por semana todos os sensores de OD eram limpos e calibrados e, mensalmente, eram realizadas a troca das membranas e da solução de eletrólitos visando manter os sensores em pleno funcionamento.

\subsubsection{Meio Suporte}

Os meios suportes aplicados nessa pesquisa foram fabricados pela empresa Aqwise Water Technologies Ltd ( Figura 4.12), com área superficial específica de $650 \mathrm{~m}^{2} \mathrm{~m}^{-3}$, diâmetro de $12 \mathrm{~mm}$, altura de $12 \mathrm{~mm}$, índice de vazios da ordem de $92 \%$ e, em cada $\mathrm{m}^{3}$ contém aproximadamente 450 mil peças.

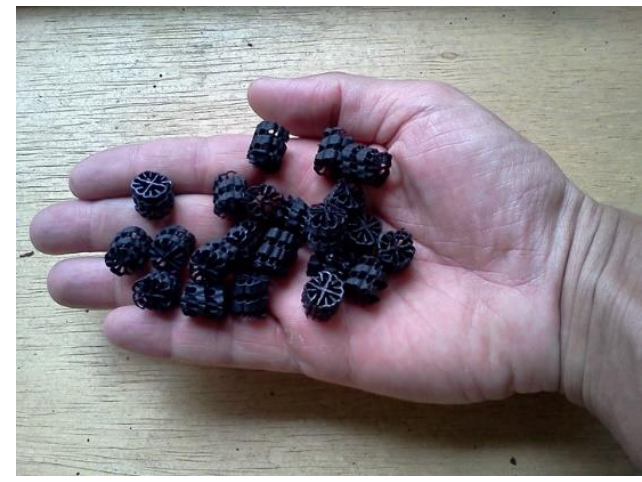

Figura 4.12: Meio suporte empregado - EmpresaAqwise 


\subsubsection{Condições Operacionais}

O delineamento experimental foi dividido em duas Etapas principais, dirigidas pela manutenção do TDH e do OD. A Etapa 1 corresponde a um TDH 5,5 horas e a Etapa 2 de 11,0 horas. O TDH foi elevado de 5,5 horas para 11,0 horas devido a baixa remoção de nitrogênio obtida na Etapa 1 e, após avaliação mais refinada feita por meio dos cálculos de projeto para sistema de lodos ativados por aeração prolongada, conforme descrito abaixo (Equações 4.1a 4.6).

Considerando $12 \mathrm{~g} \mathrm{SSV} \mathrm{m}^{-2}$ (NBR 12.209 para MBBR); volume do reator igual a $10 \mathrm{~L} ; 50 \%$ preenchimento; área superficial específica de $650 \mathrm{~m}^{2} \mathrm{~m}^{-3}$; SSVTA equivalente a $2 \mathrm{~g} \mathrm{~L}^{-1} \mathrm{e}$ concentração de DBO afluente de $400 \mathrm{mg} \mathrm{L}^{-1}$;tém-se:

- Área superficial total de biofilme:

Vol de meio suporte x Área Superficial Específica $=0,005 \mathrm{~m}^{3} \times 650 \mathrm{~m}^{2} \mathrm{~m}^{-3}=3,25 \mathrm{~m}^{2}$

(Equação 4.1)

- Quantidade Biomassa Aderida:

Área superficial total x Quantidade de Biomassa por $\mathrm{m}^{2}=3,25 \mathrm{~m}^{2} \times 12 \mathrm{~g} \mathrm{SSV} \mathrm{m}^{-2}=39 \mathrm{~g}$ SSV (Equação 4.2)

- Biomassa Total (Aderida + Suspensão):

SSVTA $\times$ Vol Reator + Quantidade Biomassa Aderida $=2 \mathrm{~g} \mathrm{~L}^{-1} \times 10 \mathrm{~L}=20 \mathrm{~g} \mathrm{SSV} \rightarrow 20 \mathrm{~g} \mathrm{SSV}+$ $39 \mathrm{~g} \mathrm{SSV}=59 \mathrm{~g}$ SSV

(Equação 4.3)

Considerando uma relação $\mathrm{A} / \mathrm{M}=0,15 \mathrm{~g} \mathrm{DBO} \mathrm{g}^{-1} \mathrm{SSV} \mathrm{d}^{-1}$, obtém-se:

- Carga de DBO:

Carga $=\mathrm{A} / \mathrm{M} \times$ Biomassa Total $=0,15 \mathrm{~g} \mathrm{DBO} \mathrm{g}^{-1} \mathrm{SSV} \mathrm{d}^{-1} \times 59 \mathrm{~g} \mathrm{SSV}=8,85 \mathrm{gd}^{-1}$

(Equação 4.4)

- Vazão afluente: 
Vazão afluente $=$ Carga/Concentração DBO afluente $=8,85 \mathrm{~g} \mathrm{~d}^{-1} / 0,4 \mathrm{~g} \mathrm{~L}^{-1}=22,12 \mathrm{~L} \mathrm{~d}^{-1}=$ $0,92 \mathrm{Lh}^{-1}$

(Equação 4.5)

- TDH:

$\mathrm{TDH}=$ Vol/Vazão afluente $=10 \mathrm{~L} / 0,92 \mathrm{Lh}^{-1}=10,87 \mathrm{~h} \approx 11 \mathrm{~h} . \quad$ (Equação 4.6)

Quanto a concentração de OD, optou-se em iniciar com uma concentração indicada para MBBR/IFAS tradicional, ou seja, OD de em torno de $4 \mathrm{mg} \mathrm{L}^{-1}$, e reduzir gradativamente até atingir uma concentração "ótima" para SND.

\subsubsection{Etapa 1}

O delineamento da Etapa1 está dividido em duas fases operacionaisgovernadas pela concentração de OD no reator IFAS.Em ambas as fases a vazão de esgoto sanitário afluente ao reator foi de $0,0424 \mathrm{~m}^{3} \mathrm{~d}^{-1}$ (TDH em torno de 5,5 horas), volume de meios suporte igual a $50 \%$ e razão de recirculação $100 \%$.

Desta forma, o único parâmetro variado foi a concentração média de OD (vazão de ar), que na Fase 1.1 foi igual a $4,5 \mathrm{mg} \mathrm{L}^{-1}$ e na Fase 1.2 de $2,4 \mathrm{mg} \mathrm{L}^{-1}$, como apresenta a Tabela 4.2.

Destaca-se que a escolha do TDH igual a 5,5 horas foi baseado nos trabalhos desenvolvidos por WANG et al. (2006) e MINEGATTI (2008).

Tabela 4.2:Condições operacionais Etapa 1

\begin{tabular}{cccc}
\hline Fases & \% meio suporte & Qar $\left(\mathrm{m}^{\mathbf{3}} \mathrm{h}^{-1}\right)$ & OD médio $\left(\mathrm{mgL}^{-1}\right)$ \\
\hline 1.1 & 50 & 0,2 & 4,5 \\
1.2 & 50 & 0,04 & 2,4 \\
\hline
\end{tabular}

É importante esclarecer que a concentração de OD foi monitorada 6 vezes ao dia por meio de um oxímetro portátil e, durante os testes de emissão de $\mathrm{N}_{2} \mathrm{O}$, por meio de uma sonda (mensurado a cada segundo). Ademais, iniciou-se essa pesquisa com a concentração média de OD de $4,5 \mathrm{mg} \mathrm{L}^{-1}$ para avaliar de maneira geral qual seria o comportamento do sistema quanto a SND. 
Além disso, a concentração de OD foi limitada a 2,4 $\mathrm{mg} \mathrm{L}^{-1}$ (Fase 1.2), devido ao fato de que para valores menores não era possível manter os meios suporte em suspensão/agitação.

\subsubsection{Etapa 2}

O delineamento da Etapa 2 está dividido em duas fases operacionais dirigidas pelo Efluente Bruto e também pela concentração de OD reator, como apresenta a Tabela 4.3. Destaca-se que trabalhou-se nesta etapa com todos reatores IFAS 1, 2 e 3.

Tabela 4.3:Condições operacionais Etapa 2

\begin{tabular}{cccccc}
\hline Fases & Reator & Efluente & \% meio suporte & Qar $\left(\mathbf{m}^{\mathbf{3}} \mathbf{h}^{-1}\right)$ & OD médio $\left(\mathrm{mgL}^{-1}\right)$ \\
\hline \multirow{2}{*}{2.1} & IFAS 1 & Efluente Sanitário & 50 & 0,033 & 2,0 \\
& IFAS 2 & Efluente Sanitário & 50 & 0,008 & 1,0 \\
& IFAS 3 & Efluente Sanitário & 50 & 0,012 & 1,5 \\
\hline \multirow{2}{*}{2.2} & IFAS 1 & Efluente Sanitário & 50 & 0,022 & 1,5 \\
& IFAS 2 & Efluente Sintético & 50 & 0,008 & 1,0 \\
& IFAS 3 & Efluente Sintético & 50 & 0,012 & 1,5 \\
\hline
\end{tabular}

A vazão de esgoto afluente ao reator IFAS 1 foi de $0.0218 \mathrm{~m}^{3} \mathrm{~d}^{-1}$ e de $0,0072 \mathrm{~m}^{3} \mathrm{~d}^{-1}$ para os reatores IFAS 2 e 3. Em todos reatores o TDH foi de aproximadamente, 11,0 horas.

Adicionou-se também no aparato experimental misturadores, trabalhando com a menor rotação possível, em torno de 200 RPM, visando manter em agitação e suspensão a massa líquidae os meios suportes.

\subsection{Efluente Bruto}

O efluente Sanitário utilizadona Etapa 1 e na Fase 2.1 da Etapa 2 foi o esgoto bruto queé recalcado ao CESA/UFRJ - proveniente das duas elevatórias.

Todavia, na Fase 2.2 da Etapa 2, nos reatores IFAS 2 e 3,o efluente brutofoi desenvolvido em laboratório (efluente sintético), e sua característica está descrita na Tabela 4.4. Esseefluente era preparado a cada dois dias de modo a garantir sua integridade. Adicionou-se também uma solução de micronutrientes, cuja composição está detalhada 
na Tabela 4.5. Essa solução foi adicionada na razão de $0,5 \mathrm{~mL}$ para cada litro de efluente produzido.

A concentração de matéria orgânica, expressa em termos de DQO, foi ajustada para em torno de $600 \mathrm{mg} \mathrm{L}^{-1}$ por meio de quantidades definidas desacarose. A concentração de amônio foi fixada em, aproximadamente, $35 \mathrm{mg} \mathrm{N}-\mathrm{NH}_{4}{ }^{+} \mathrm{L}^{-1}$ por meio da adição de cloreto de amônio. O bicarbonato de sódio era a fonte de alcalinidade do sistema, com objetivo de manter o pH controlado, uma vez que a nitrificação leva a uma redução do mesmo. Já os fosfatos eram a fonte de fósforo, no entanto também contribuíram para a manutenção do pH (HANAKI et al. 1990).

Tabela 4.4:Característica do efluente sintético

\begin{tabular}{cc}
\hline Composto & Concentração $\left(g \cdot L^{-1}\right)$ \\
\hline Sacarose & 144,0 \\
$\mathrm{~K}_{2} \mathrm{HPO}_{4}$ & 7,0 \\
$\mathrm{KH}_{2} \mathrm{PO}_{4}$ & 6,0 \\
$\mathrm{NH}_{4} \mathrm{Cl}$ & 120,0 \\
$\mathrm{NaHCO}_{3}$ & 0,6 \\
$\mathrm{NaCl}$ & 300,0 \\
\hline
\end{tabular}

Tabela 4.5:Característica da solução de micronutrientes

\begin{tabular}{cc}
\hline Composto & Concentração $\left(\mathbf{g} \cdot \mathbf{L}^{-1}\right)$ \\
\hline $\mathrm{MgCl}_{2} \cdot 6 \mathrm{H}_{2} \mathrm{O}$ & 8,6 \\
$\mathrm{CaCl}_{2} \cdot 2 \mathrm{H}_{2} \mathrm{O}$ & 5,54 \\
$\mathrm{EDTA}$ & 50,0 \\
$\left(\mathrm{NH}_{4}\right) 6 \mathrm{Mo}_{7} \mathrm{O}_{24}$ & 1,036 \\
$\mathrm{MnCl}_{2}$ & 3,22 \\
$\mathrm{ZnSO}_{4}$ & 12,354 \\
$\mathrm{CoCl}_{2}$ & 0,88 \\
$\mathrm{CuSO}_{4}$ & 1,004 \\
$\mathrm{FeSO}_{4}$ & 2,728 \\
\hline
\end{tabular}

Salienta-se que a cada dois dias a elevatória do efluente sintético era limpa com objetivo de eliminar qualquer contaminante.Além disso, todas as mangueiras utilizadas para 
recalque do efluente sintético era lavadas semanalmente e, uma vez por mês, as mangueiras eram substituídas por mangueiras limpas e desinfectadas com Hipoclorito de Sódio para completa remoção de seja qual for o contaminante e incrustação que tenha ocorrido.

Ademais, segundo PLATTESet. al (2006) e KERMANlet. al (2008), quando se emprega efluente sintético, deve-se avaliar a eficiência de remoção de matéria orgânica do processo considerando somente a parcela solúvel. Isso porque é produzido uma elevada quantidade de polímeros extracelulares (EPS), que interfere enormemente na sedimentação do lodo. Do mesmo modo, considera-se também que estamos trabalhando com um decantador ideal (VON SPERLING, 2002).

\subsection{Inóculo e Start-up}

O inóculo usado para o período de partida (start-up) do sistema foi oriundo do sistema de lodos ativados da ETE Alegria, localizada no bairro do Caju, no município do Rio de Janeiro - RJ.

Para inoculação do sistema no reator IFAS 1 - Etapa 1, foram utilizados cerca de 5 L do lodo de recírculo e mantido o OD estipulado, igual a 4,3 mg. $\mathrm{L}^{-1}$. Posteriormente, durante a primeira semana, o reator foi alimentado com uma vazão de $0,0097 \mathrm{~m}^{3} . \mathrm{d}^{-1}$ com efluente do CESA/UFRJ, a fim de garantir um TDH de $24 \mathrm{~h}$. Na segunda semana de aclimatação o TDH foi reduzido para $18 \mathrm{~h}$, com uma alimentação de $0,0130 \mathrm{~m}^{3} \cdot \mathrm{d}^{-1}$. Na terceira semana o TDH foi reduzido para $12 \mathrm{~h}$, com a vazão afluente de projeto de $0,0194 \mathrm{~m}^{3} \cdot \mathrm{d}^{-1}$; até alcançar a vazão de projeto de $0,0424 \mathrm{~m}^{3} \cdot \mathrm{d}^{-1}$, obtendo o TDH de projeto igual a 5,5 h. Assim, durante o período de aclimatação, ocorreu a colonização dos meios suporte pelos microrganismos, formando o biofilme.

Na Etapa 2, para os reatores IFAS 2 e 3, foi adotada a mesma metodologia do reator IFAS 1 (50\% do volume com inóculo), matendo a concentração de OD de projeto de $1,0 \mathrm{mgL}^{-1} \mathrm{e}$ $1,5 \mathrm{mgL}^{-1}$ e adicionando o efluente sintético.

Contudo, houve um imprevisto técnico nos reatores IFAS 2 e 3 durante o experimentoque acarretou em um nova partida, na qual seráexplanado no item subsequente. Desta maneira, para essa segunda partida, removeu-se toda biomassa em suspensão e "lavou- 
se" os reatores IFAS 2 e 3 com os meios suportes dentro deles. Posteriormente, introduziu novamente1,5 litros do lodo de recírculo da ETE Alegria e iniciou-se a alimentação com o efluente sintético, mantendo o TDH e o OD de projeto.

Ressalta-se que não há nenhuma informação na literatura a respeito de aclimatação e/ou Start-upde reatores biológicos com intuito de desenvolver a SND.

\subsection{Atividades da Pesquisa}

\subsubsection{Procedimentos de Operação}

A operação e monitoramento do processo foi iniciado em Junho de 2014 até Novembro de 2015.

\subsubsection{Monitoramento e Sistema de Amostragem}

O monitoramento das unidades contou com coletas de amostras pontuais realizadas duas a três vezes por semana. Na Tabela 4.6 são indicados, para cada ponto de amostragem, os parâmetros físico-químicos que foram analisados pelo Laboratório de Engenharia do Meio Ambiente da Escola Politécnica da UFRJ - LEMA/UFRJ, conforme preconizaStandard Methods for the Examination of Water and Wastewater- APHA 22ed (2012) e/oucomo indicado na Tabela 4.7.

Tabela 4.6: Pontos de amostragem

\begin{tabular}{|c|c|}
\hline Local da Coleta & Parâmetros \\
\hline Afluente & $\mathrm{DQO}^{1}$, Sólidos $^{2}, \mathrm{~N}^{3}, \mathrm{pH},{\mathrm{P}-\mathrm{PO}_{4}, \text { Cloretos }^{4} \text {, Alcalinidade }}$ \\
\hline Efluente do Decantador & $\mathrm{DQO}^{1}$, Sólidos$^{2}, \mathrm{~N}^{3}, \mathrm{pH}, \mathrm{DBO}{ }^{5},{\mathrm{P}-\mathrm{PO}_{4}}$, Cloretos ${ }^{4}$, Alcalinidade \\
\hline Tanque de Aeração & Sólidos², OD, Temperatura, pH \\
\hline Meio suporte & Sólidos ${ }^{6}$ \\
\hline Lodo Excesso & Sólidos ${ }^{2}$, IVL \\
\hline
\end{tabular}
1. Total e solúvel.
2. ST, SV, SF, SST, SSV, SSF.
3. $\mathrm{NTK}, \mathrm{N}-\mathrm{NH}_{4}, \mathrm{~N}-\mathrm{NO}_{2}$ e N-NO .
4. Somente para o reator IFAS 1.
5. Realizado a cada 2 semanas.
6. Ver metodologia. 
Tabela 4.7:Parâmetros analisados com respectivos métodos adotados

\begin{tabular}{|c|c|}
\hline Parâmetros & Método \\
\hline \multirow{2}{*}{ DQO } & 5220 D - Closed reflux, Colorimétrico \\
\hline & 5220 B - Open reflux, Titulométrico \\
\hline DBO & $5210 \mathrm{~B}$ \\
\hline \multirow{2}{*}{$\mathrm{N}-\mathrm{NH}_{4}$} & $4500 \mathrm{~F}-$ Indofenol \\
\hline & 4500 C - Nesslerização (Nessler) ${ }^{1}$ \\
\hline $\mathrm{N}-\mathrm{NO}_{2}$ & 4500 B - Colorimétrico \\
\hline $\mathrm{N}-\mathrm{NO}_{3}$ & Método 8171 ou 8039 - HACH \\
\hline NTK & 4500 C - Digestão/Destilação/Titulação \\
\hline \multirow{2}{*}{ Sólidos } & Marcha Sólidos Totais: 2540 B \\
\hline & Marcha Sólidos em Suspensão: 2540 D \\
\hline $\mathrm{P}-\mathrm{PO}_{4}$ & 4500 E - Ácido Ascórbico \\
\hline Cloretos & 4500 B - método Mohr \\
\hline Alcalinidade & 2320 B - Titulométrico com indicador \\
\hline
\end{tabular}

1. Método Nesslerização mais indicado para efluente sintético - Standard Methods for the Examination of Water and Wastewater - APHA 22ed (2012).

O OD e Temperatura foram monitorados por meio do equipamentoda marca Hach, modelo HI9146 e o pH pelo pHmetro digital portátil microprocessado fabricado pela empresa Gehaka - modeloPG 1400. Ambos aparelhos/sondas eram calibradas rotineiramente.

\subsubsection{Sólidos Aderidos ao Meio Suporte}

Para quantificação da biomassa aderida ao meio suporte foram realizadas análises semanais, de acordo com a seguinte metodologia:

- Retira-se aleatoriamente oito peças do interior do tanque de aeração;

- Remove-se toda biomassa aderida das mesmas com auxílio de uma espátula e escova, transferindo para um recipiente com água destilada $(100 \mathrm{~mL})$;

- Com toda a biomassa já depositada neste recipiente, realiza-se a marcha total de sólidos conforme preconiza APHA (2012). 
A Figura 4.13 ilustra o momento quando era realizada a metodologia supracitada, detalhando o meio suporte com biomassa aderida e ao fundo, o recipiente contendo água destilada + biomassa.

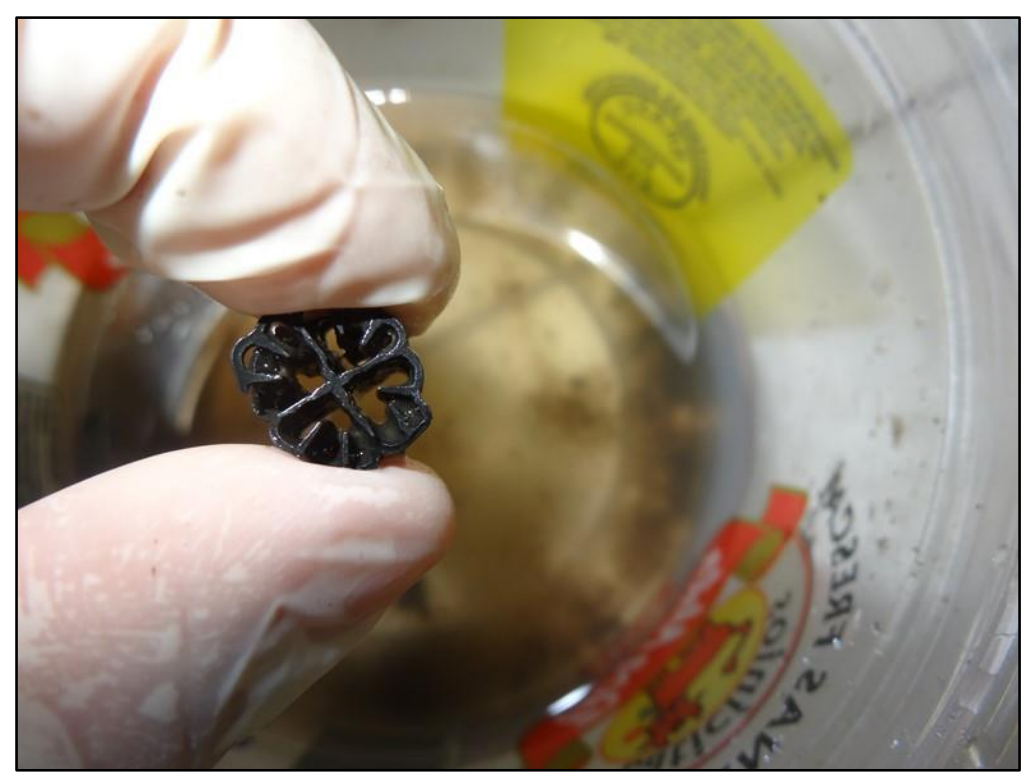

Figura 4.13: Aplicação da metodologia para quantificação da biomassa aderida ao meio suporte

\subsubsection{Emissão de Óxido Nitroso $\left(\mathrm{N}_{2} \mathrm{O}\right)$}

Para a determinação do fluxo de $\mathrm{N}_{2} \mathrm{O}$ na interface esgoto-atmosfera no reator foi utilizada como metodologia de amostragem, a técnica do funil emborcado descrita detalhadamente por BROTTOet al.(2010). Essa técnica permite a captação das bolhas de ar que se desprendem da superfície do reator, com a finalidade de se determinar a concentração de $\mathrm{N}_{2} \mathrm{O}$ no ar desprendido do esgoto para posterior cálculo do fluxo do gás. A concentração de $\mathrm{N}_{2} \mathrm{O}$ foi obtida, in loco, com o emprego do equipamento Los Gatos Research da empresa $A B B$, o qual quantifica, a cada segundo, a emissão de $\mathrm{N}_{2} \mathrm{O}$. As Figuras 4.14 e 4.15 ilustram o equipamento em funcionamento e a tela em destaque, nesta ordem. 


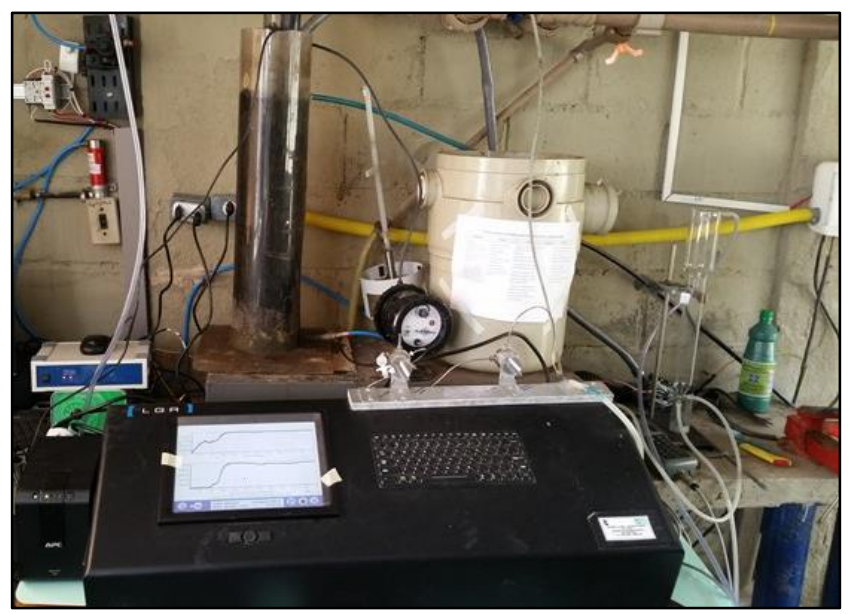

Figura 4.14: Equipamento Los Gatos

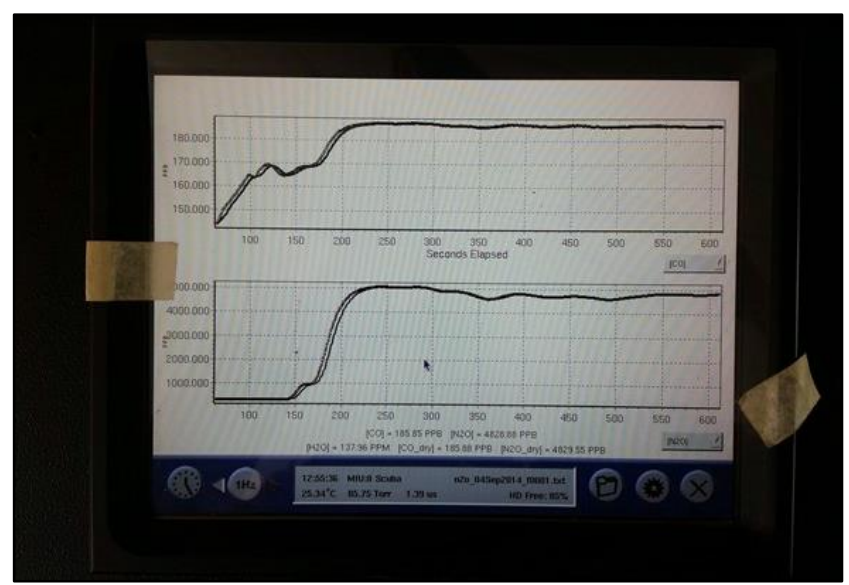

Figura 4.15: Detalhe da tela do equipamento Los Gatos

Salienta-se que, por meio desta análise é possível fazer um balanço de massa mais preciso de todo material nitrogenado, ou seja, avaliar toda a massa de nitrogênio que entra no sistema, que é consumido e o que é produzido/gerado.

\subsubsection{Análise Estatística}

Os resultados obtidos neste trabalho foram analisados estatisticamente utilizando o programa Excel-Windows. Foram realizadas análises de variância das diferenças entre os valores médios de eficiência dos principais parâmetros monitorados, utilizando o teste $\mathrm{t}$ de Student (test-t) bicaudal com um nível de significância de $95 \%(P<0,05)$. Assim, foi possível verificar se há ou não diferença entre as fases operacionais. 


\section{RESULTADOS E DISCUSSÃO}

Neste capítulo serão apresentados os resultados, dividos da seguinte forma:

- Etapa 1;

- Etapa 2;

- Comparação entre Etapa 1 e Etapa 2;

- Avaliação da Emissão de N2O.

\subsection{Etapa 1}

\subsubsection{Fase 1.1}

\subsubsection{Análises físico-químicas}

A Tabela 5.1 apresenta os resultados obtidos durante a Fase 1.1, especificamente em relação as análises físico-químicas. Ao analisar os resultados experimentais, observa-se que as eficiências médias de matéria orgânica, DQO e $\mathrm{DQO}_{\text {sol, }}$, foram de 52\% e 56\%, respectivamente, alcançando valores da ordem de $80 \%$ considerando o percentil de 90 .

Quanto as eficiências de remoção de SST, observa-se que houve o mesmo comportamento da matéria orgânica, isto é, eficiência média de $60 \%$, obtendo valores de aproximadamente, $83 \%$ para percentil 90 .

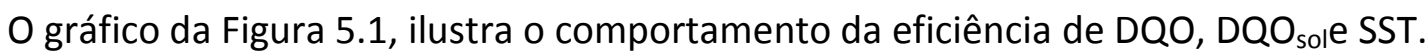


Tabela 5.1:Resultados do monitoramento do Reator IFAS 1 - Fase $1.1\left(\mathrm{mg} \mathrm{L}^{-1}\right)$

\begin{tabular}{|c|c|c|c|c|c|c|c|c|c|c|}
\hline \multirow{2}{*}{\multicolumn{2}{|c|}{ Parâmetro }} & \multirow{2}{*}{$\begin{array}{l}\text { № de } \\
\text { dados }\end{array}$} & \multirow{2}{*}{ Média } & \multirow{2}{*}{$\begin{array}{l}\text { Desvio } \\
\text { Padrão }\end{array}$} & \multirow{2}{*}{$\begin{array}{l}\text { Coeficiente } \\
\text { de Variação }\end{array}$} & \multicolumn{5}{|c|}{ Percentis } \\
\hline & & & & & & 10 & 25 & 50 & 75 & 90 \\
\hline \multirow{3}{*}{ DQO } & Afl & 13 & 324 & 119 & 0,37 & 211 & 263 & 324 & 327 & 503 \\
\hline & Efl & 13 & 159 & 81 & 0,51 & 88 & 115 & 154 & 183 & 256 \\
\hline & Ef (\%) & 13 & 52 & 17 & 0,33 & 37 & 44 & 49 & 55 & 77 \\
\hline \multirow{3}{*}{ DQOsol } & Afl & 13 & 123 & 25 & 0,20 & 92 & 100 & 133 & 135 & 148 \\
\hline & Efl & 13 & 80 & 31 & 0,39 & 40 & 59 & 79 & 110 & 114 \\
\hline & Ef (\%) & 13 & 56 & 32 & 0,60 & 24 & 44 & 54 & 60 & 84 \\
\hline \multirow{3}{*}{ SST } & Afl & 13 & 187 & 103 & 0,55 & 85 & 88 & 166 & 278 & 330 \\
\hline & Efl & 13 & 98 & 75 & 0,77 & 48 & 58 & 72 & 94 & 166 \\
\hline & Ef (\%) & 13 & 60 & 22 & 0,36 & 41 & 48 & 59 & 81 & 83 \\
\hline \multirow{3}{*}{ NTK } & Afl & 13 & 58 & 22 & 0,39 & 38 & 42 & 53 & 78 & 83 \\
\hline & Efl & 13 & 38 & 14 & 0,38 & 26 & 28 & 35 & 46 & 58 \\
\hline & Ef (\%) & 13 & 31 & 14 & 0,45 & 17 & 22 & 27 & 33 & 53 \\
\hline \multirow{3}{*}{$\mathrm{N}-\mathrm{NH}_{4}$} & Afl & 13 & 18 & 7 & 0,37 & 9 & 12 & 21 & 22 & 24 \\
\hline & Efl & 13 & 5 & 5 & 0,97 & 2 & 3 & 3 & 6 & 9 \\
\hline & Ef (\%) & 13 & 71 & 21 & 0,30 & 51 & 66 & 74 & 86 & 89 \\
\hline \multirow{2}{*}{$\mathrm{N}-\mathrm{NO}_{2}$} & Afl & 13 & 0,13 & 0,06 & 0,48 & 0,06 & 0,07 & 0,12 & 0,19 & 0,20 \\
\hline & Efl & 13 & 0,85 & 0,41 & 0,48 & 0,53 & 0,72 & 0,81 & 0,95 & 1,25 \\
\hline \multirow{2}{*}{$\mathrm{N}-\mathrm{NO}_{3}$} & Afl & 13 & 2,6 & 2,7 & 1,0 & 0,07 & 0,78 & 1,85 & 3,65 & 6,05 \\
\hline & Efl & 13 & 12,5 & 5,7 & 0,46 & 7,02 & 9,83 & 13,20 & 16,78 & 17,66 \\
\hline
\end{tabular}

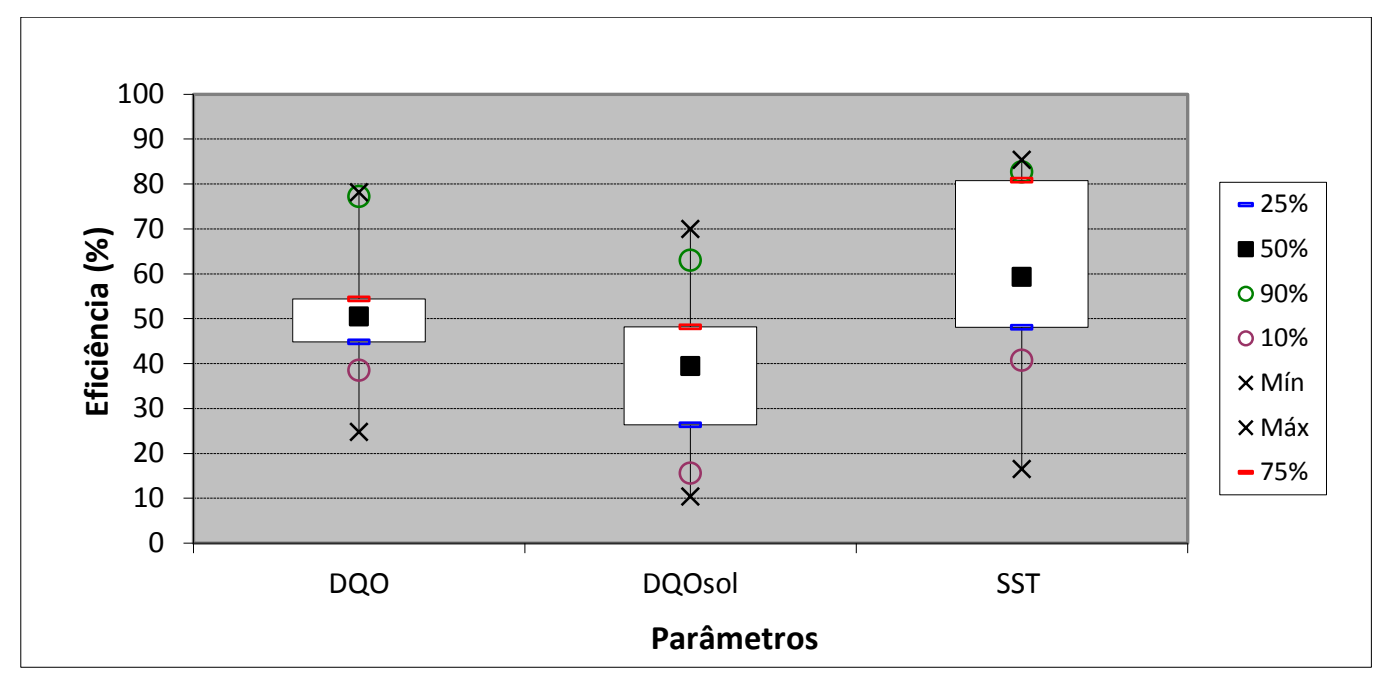

Figura 5.1:Eficiência de remoção de DQO, $\mathrm{DQO}_{\text {sol }}$ e SST

Pode-se afirmar que a eficiência de remoção de matéria orgânica foi bastante limitada.

Tal fato pode ser justificado devidoa elevada perda de sólidos no efluente, concentração média de SST efluente igual a $98 \mathrm{mg} \mathrm{L}^{-1}$.

Outro fator importante que deve ser analisado é que o reator já estava em operação por cerca de 40 dias, mantendo concentração de SSV em suspesão relativamente constante, igual a $700 \mathrm{mg} \mathrm{L}^{-1}$. Contudo, a DBA ainda variava bastante (Tabela 5.2), indicando que o biofilme ainda estava em formação/crescimento. 
Tabela 5.2:Resultados de DBA ( $\mathrm{mg} \mathrm{L}^{-1}$ ) e SSV expresso emg $\mathrm{m}^{-2}$ ao longo da Fase 1.1

\begin{tabular}{cc}
\hline Amostragem & DBA $\left(\mathrm{mg} \mathrm{L}^{-1}\right)$ ou $\mathbf{~ g ~ m}^{-2}$ \\
\hline 1 & 1705 ou 6,3 \\
2 & 1541 ou 5,7 \\
3 & 2358 ou 8,7 \\
\hline
\end{tabular}

Quandose observa a variação da concentração efluente de SST ao logo do tempo comparando com a eficiência de remoção de SST (Figura 5.2), percebe-se uma tendência demelhoria de eficiência no final do período de monitoramento desta fase.

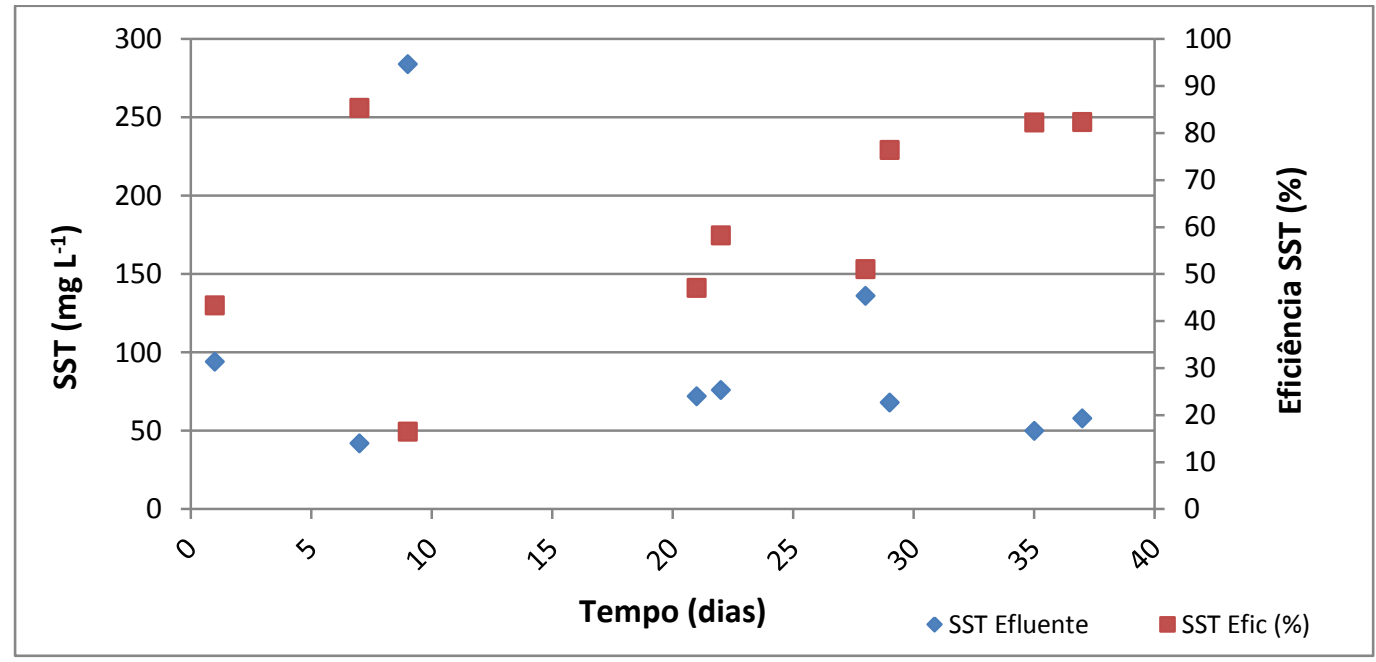

Figura 5.2:Concentração efluente e eficiência de remoção de SST

O gráfico da Figura 5.3 reforça a hipótese de que o processo ainda não estava no estado estacionário visto que, de acordo com RUSTEN et al. (1995, 1997 e 1998), ØDEGAARD et al. (1993 e 1994) e MINEGATTI (2008), quanto maior a COS aplicada no processo MBBR/IFAS, mais elevada é a eficiência de remoção de matéria orgânica. 


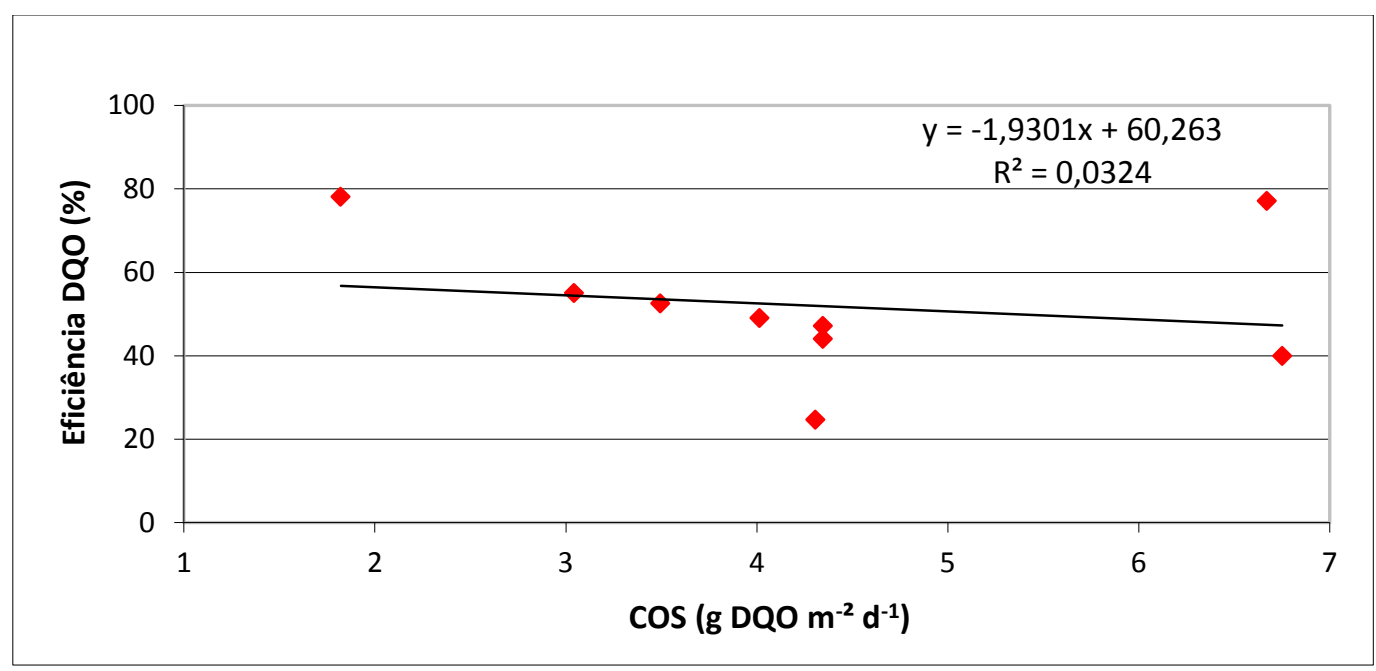

Figura 5.3:COS versuseficiência de DQO

Em relação a nitrificação, nota-se que a remoção média de $\mathrm{N}-\mathrm{NH}_{4}$ foi superior a $70 \%$ e a produção de $\mathrm{N}-\mathrm{NO}_{3}$ foi cerca de $500 \%$ (praticamente não houve variação de $\mathrm{N}-\mathrm{NO}_{2}$ ). $\mathrm{Ou}$ seja, a elevada concentração de $\mathrm{OD}$, em torno de $4,5 \mathrm{mg} \mathrm{L}^{-1}$, foi suficiente para que ocorresse o processo de nitrificação (Figura 5.4), considerando a inconstante e baixaconcentração de biomassa aderida.Já ográfico da Figura 5.5 ilustra as concentrações afluente e efluente de NTK, indicando limitada remoção de NTK.

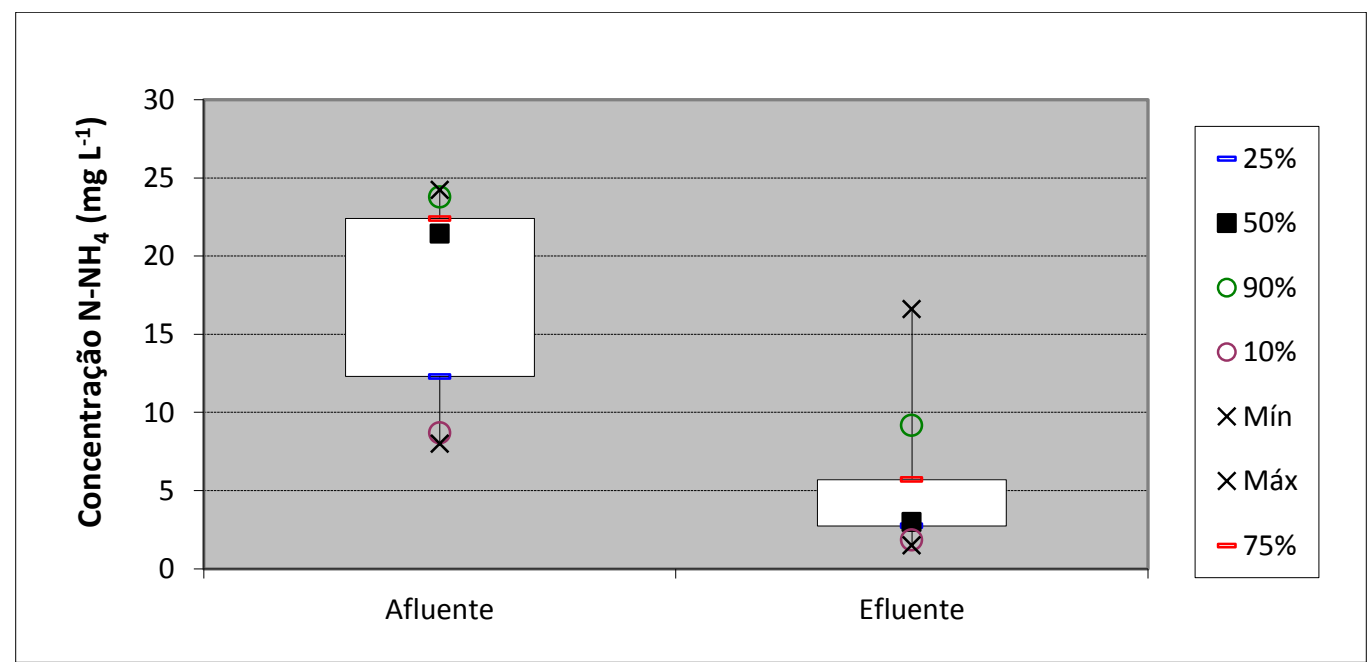

Figura 5.4: Concentrações afluente e efluente de $\mathrm{N}-\mathrm{NH}_{4}$ 


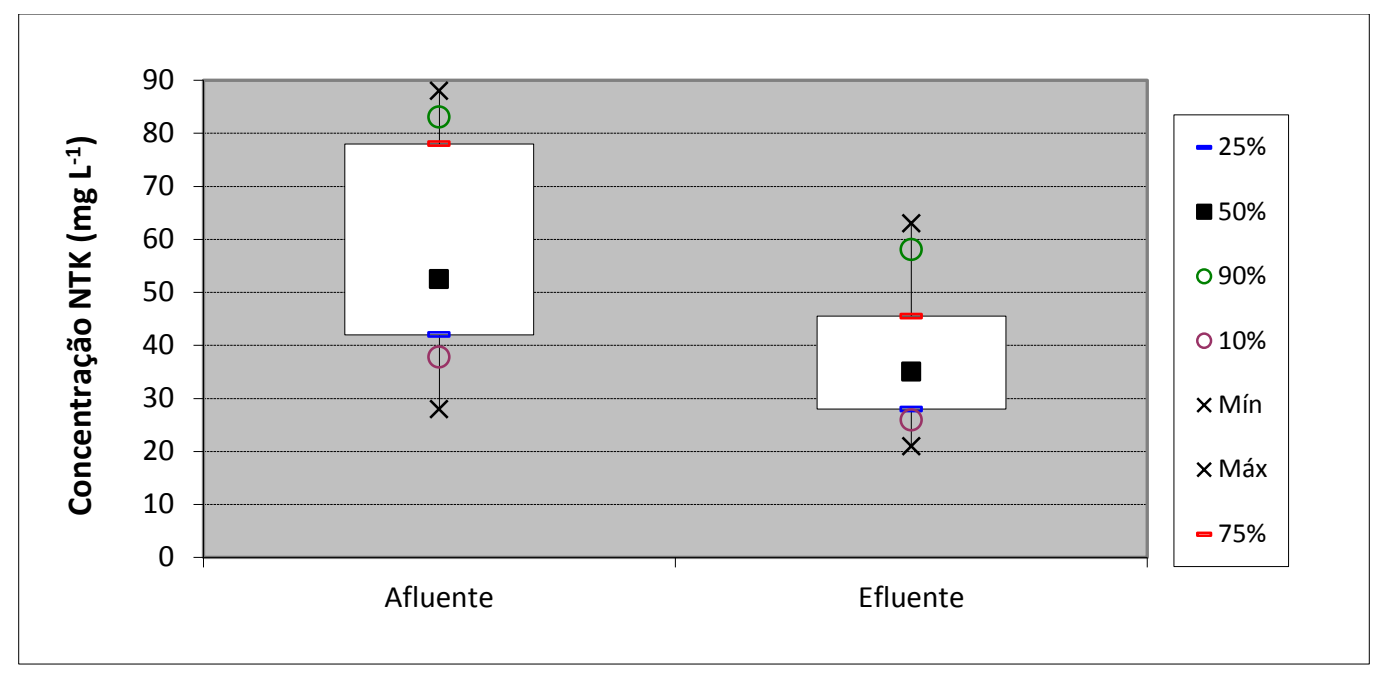

Figura 5.5: Concentrações afluente e efluente de NTK

Avaliando a remoção de NT, que corresponde ao somatório de NTK, Nitrito e Nitrato, observa-se que foi da ordem de14\%, sabendo que existe uma fração de nitrogênio que é assimilado pelos microrganismos (síntese celular), que varia conforme a idade do lodo. Em idade do lodo elevada o nitrogênio assimilado microbiologicamente retornará à fase líquida devido à amonificação dada pela morte das células (METCALF \& EDDY, 2003), alcançando valores da ordem de 7\% de NTK (VON SPERLING, 2005).

Assim, considerando esses fatores, pode-se indicar que a remoção de NTfoi praticamente nula, sendo ele somente convertido e/ou consumido.

\subsubsection{Parâmetros Operacionais e de Controle}

Em relação aos parâmetros operacionais, especificamente, as cargas orgânicas superficial

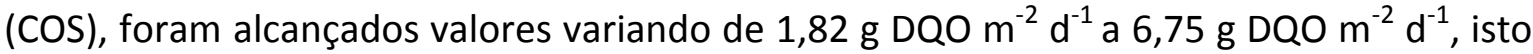
considerando uma área total presente no reator igual a $3,25 \mathrm{~m}^{2}$, promovida pelo volume de $5 \mathrm{~L}$ de meios suporte.Tal valor encontrado para COS, considerando estudo de HEM el al. (1994) (Figura 3.9), são bastante elevados, sendo necessária concentrações de OD acima de $8,0 \mathrm{mg} \mathrm{L}^{-1}$ para que ocorra a nitrificação de forma efetiva.

Quanto a biomassa presente no reator, a massa total média encontrada foi igual a $36,5 \mathrm{gSST}$, equivalente a $25,9 \mathrm{gSSV}$, onde em torno de $71 \%$ estavam aderidos ao meio suporte (25,5 g SST e 18,7 g SSV), obtendo valor médio de DBA da ordem de $1868 \pm 353$

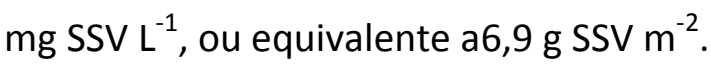


Quando comparado esses valores com os reportados pela literatura, nota-se que a DBA encontrada foi similar aos obtidos por JAHRENet al. (2002), igual a 1.400 e 1.900 mg SSV L' ${ }^{1}$ e MARTín-PASCUALet al. (2012), compreendidos entre $1.190 \mathrm{mg} \mathrm{SSV} \mathrm{L}^{-1}$ a $1.615 \mathrm{mg}$ SSV $\mathrm{L}^{-1}$ e superiores a LEYVA-DíAZet al. (2013)a equivalente a $1.035 \pm 345 \mathrm{mg} \mathrm{SSV} \mathrm{L}^{-1}$. Para a quantidade de biomassa expressa em g SSV $\mathrm{m}^{-2}$, observa-se que o valor obtido de 6,9 $\mathrm{g}$ SSV $\mathrm{m}^{-2}$ foi superior aos alcançados por ANDREOTTOLA et al. (2003b) e HONG-BINet al. (2007), igual a 4,0 g SST $\mathrm{m}^{-2}$ e 5,0 $\mathrm{g} \mathrm{SSV} \mathrm{m}^{-2}$, respectivamente; e inferior aoatingido por MINEGATTI (2008) de 15,6 g SSV m ${ }^{-2}$.

Salienta-se que a relação SSV/SST foi de $71 \%$ para a biomassa em suspensão e $73 \%$ para a biomassa aderida.

A Idade do Lodo foi controlada por meio da manta de lodo no decantador e pelo volume de lodo descartado rotineiramente, obtendo um valor médio de 57 dias, valor elevado quando comparado ao sistema de lodos ativados por aeração prolongada, por exemplo. Isso contribui para a teoria que somente uma pequena fração do nitrogênio era assimilado pelos microrganismos e que essa elevada Idade do Lodo contribuiu para o acúmulo de lodo no decantador que, por sua vez, influenciou na eficiência de remoção de SST (média de somente 60\%).

Em relação a razão Alimento/Microrganismo $(\mathrm{A} / \mathrm{M})$, trabalhou-se com valores da ordem de 2,3 $\mathrm{kg}$ DQO kg SSV$^{-1} \mathrm{dia}^{-1}$ considerando somente a biomassa em suspensão e de 0,5 kg DQO kg SSV ${ }^{-1} \mathrm{dia}^{-1}$ para toda a biomassa presente no reator (aderida + suspensa).

Ressalta-se que durante toda esta fase não se observou a flotação do lodo no decantador, sendo que o índice volumétrico de lodo (IVL) se manteve em torno de $120 \mathrm{~mL} \mathrm{~g}^{-1}$.

A temperatura e o pH no reator se mantiveram praticamente constantes durante toda fase, com temperatura variando entre 20,5 e $23,0 \stackrel{\circ}{ } \mathrm{C}$ e $\mathrm{pH}$ entre6,4 e 6,8 para entrada e entre 6,3 e 6,5 na saída do reator.

Já a respeito da concentração de $\mathrm{OD}$, conforme informado, durante o experimento da emissão de $\mathrm{N}_{2} \mathrm{O}$, monitorou-se a concentração de $\mathrm{OD}$ (medição a cada segundo). Desta forma, o gráfico da Figura 5.6, ilustra o comportamento da concentração de OD ao longo do período de monitoramento, alcançando um valor médio de $4,5 \mathrm{mg} \mathrm{L}^{-1}$. 


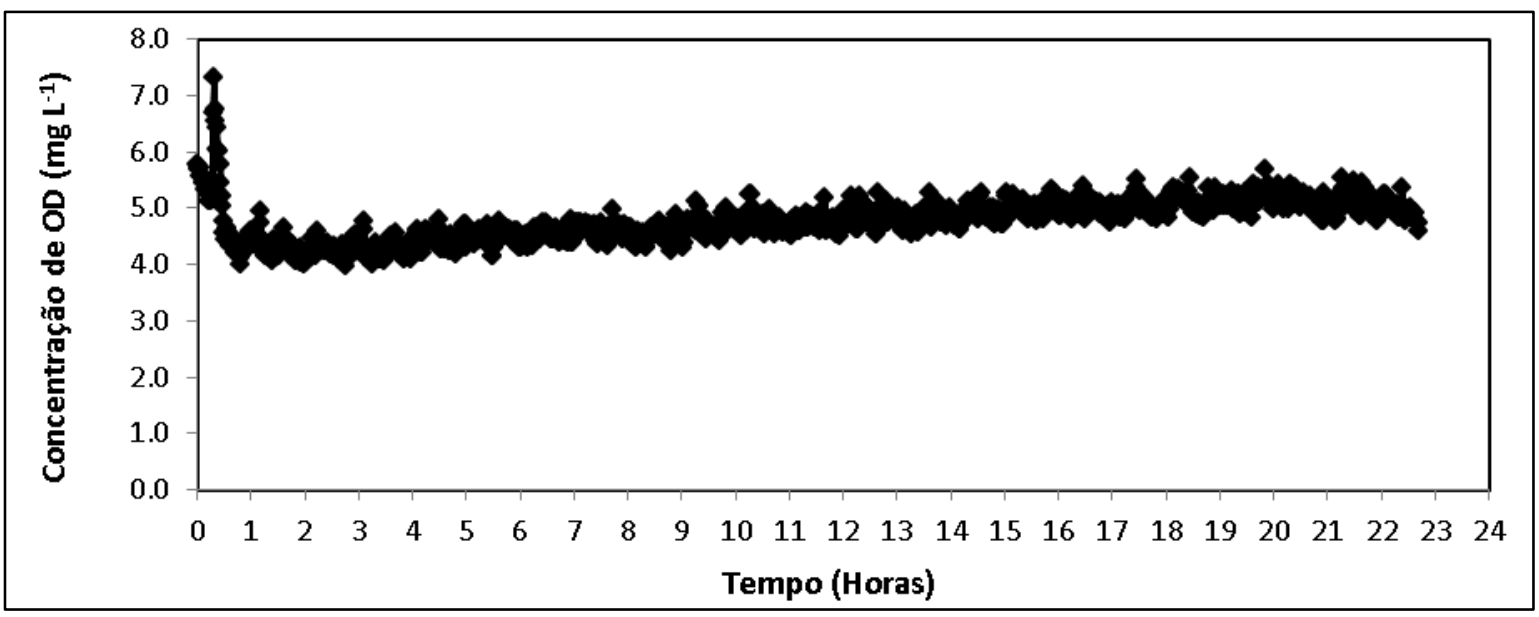

Figura 5.6: Concentração de $\mathrm{OD}$ ao longo do período de monitoramento de $\mathrm{N}_{2} \mathrm{O}$

\subsubsection{Fase 1.2}

\subsubsection{Análises físico-químicas}

A Tabela 5.3 apresenta os resultados das análises físico-químicas obtidos durante a Fase 1.2. Nota-se que houve uma evolução em relação a remoção da matéria orgânica (DQO e $\mathrm{DQO}_{\text {sol }}$ ) e de SST quando comparado com a Fase 1.1, obtendo eficiências médias iguais a $77 \%, 67 \%$ e $87 \%$, respectivamente. O gráfico da Figura 5.7 apresenta os resultados alcançados referente as eficiências de remoção DQO, DQOsole SST. Já as concentrações médias efluente obtidas foram equivalentes a $107 \mathrm{mg} \mathrm{L}^{-1}, 46 \mathrm{mg} \mathrm{L}^{-1} \mathrm{e} 54 \mathrm{mg} \mathrm{L}^{-1}$ para DQO, DQOsol e SST respectivamente.

Outro ponto importante que deve ser avaliado a respeito da remoção de matéria orgânica é que cerca de $70 \%$ da DQO afluente está na forma de DQO particulada (DQO DQOsolúvel). Desta forma, considerando o TDH adotado igual a 5,5 horas, grande parte desta DQO particulada não poderá ser removida pelo fato da limitação do metabolismo microbiano, impossibilitando assim alcançar eficiências mais elevadas.

De qualquer forma, percebe-se por meio do gráfico da Figura 5.8 que o comportamento do reator quanto a remoção de matéria orgânica foi de acordo com o indicado por RUSTEN et al. (1995, 1997 e 1998), ØDEGAARD et al. (1993 e 1994) e MINEGATTI (2008). Isto é, quanto maior a COS aplicada maior é a eficiência de remoção de matéria orgânica. 
Tabela 5.3: Resultados do monitoramento do Reator IFAS 1 - FASE $1.2\left(\mathrm{mg} \mathrm{L}^{-1}\right.$ )

\begin{tabular}{|c|c|c|c|c|c|c|c|c|c|c|}
\hline \multirow{2}{*}{\multicolumn{2}{|c|}{ Parâmetro }} & \multirow{2}{*}{$\begin{array}{l}\text { № de } \\
\text { dados }\end{array}$} & \multirow{2}{*}{ Média } & \multirow{2}{*}{$\begin{array}{l}\text { Desvio } \\
\text { Padrão }\end{array}$} & \multirow{2}{*}{$\begin{array}{l}\text { Coeficiente } \\
\text { de Variação }\end{array}$} & \multicolumn{5}{|c|}{ Percentis } \\
\hline & & & & & & 10 & 25 & 50 & 75 & 90 \\
\hline \multirow{3}{*}{ DQO } & Afl & 18 & 518 & 163 & 0,31 & 319 & 408 & 482 & 652 & 706 \\
\hline & Efl & 18 & 107 & 23 & 0,21 & 87 & 98 & 102 & 119 & 134 \\
\hline & Ef (\%) & 18 & 77 & 8 & 0,11 & 65 & 71 & 80 & 83 & 86 \\
\hline \multirow{3}{*}{ DQOsol } & Afl & 18 & 138 & 36 & 0,26 & 87 & 106 & 145 & 170 & 178 \\
\hline & Efl & 18 & 46 & 25 & 0,55 & 27 & 30 & 30 & 58 & 88 \\
\hline & Ef (\%) & 18 & 67 & 13 & 0,11 & 56 & 61 & 68 & 77 & 79 \\
\hline \multirow{3}{*}{ SST } & Afl & 18 & 345 & 256 & 0,74 & 133 & 213 & 257 & 409 & 532 \\
\hline & Efl & 18 & 54 & 32 & 0,29 & 17 & 28 & 48 & 77 & 94 \\
\hline & Ef (\%) & 18 & 82 & 9 & 0,22 & 72 & 76 & 83 & 89 & 93 \\
\hline \multirow{3}{*}{ NTK } & Afl & 18 & 42 & 14 & 0,33 & 25 & 35 & 44 & 53 & 53 \\
\hline & Efl & 18 & 18 & 8 & 0,48 & 11 & 13 & 17 & 20 & 29 \\
\hline & Ef (\%) & 18 & 59 & 17 & 0,29 & 37 & 49 & 66 & 71 & 75 \\
\hline \multirow{3}{*}{$\mathrm{N}-\mathrm{NH}_{4}$} & Afl & 18 & 25 & 16 & 0,63 & 13,6 & 19,9 & 22,0 & 27,5 & 28,6 \\
\hline & Efl & 18 & 12 & 8 & 0,67 & 3,8 & 6,0 & 11,6 & 15,5 & 19,0 \\
\hline & Ef (\%) & 18 & 54 & 22 & 0,40 & 30 & 41 & 49 & 69 & 85 \\
\hline \multirow{2}{*}{$\mathrm{N}-\mathrm{NO}_{2}$} & Afl & 18 & 0,32 & 0,20 & 0,63 & 0,19 & 0,20 & 0,20 & 0,42 & 0,50 \\
\hline & Efl & 18 & 1,06 & 0,45 & 0,42 & 0,61 & 0,72 & 1,00 & 1,35 & 1,46 \\
\hline \multirow{2}{*}{$\mathrm{N}-\mathrm{NO}_{3}$} & Afl & 18 & 1,05 & 1,01 & 0,97 & 0,20 & 0,30 & 0,50 & 1,95 & 2,50 \\
\hline & Efl & 18 & 6,16 & 2,06 & 0,33 & 4,22 & 4,75 & 5,60 & 6,85 & 8,08 \\
\hline
\end{tabular}

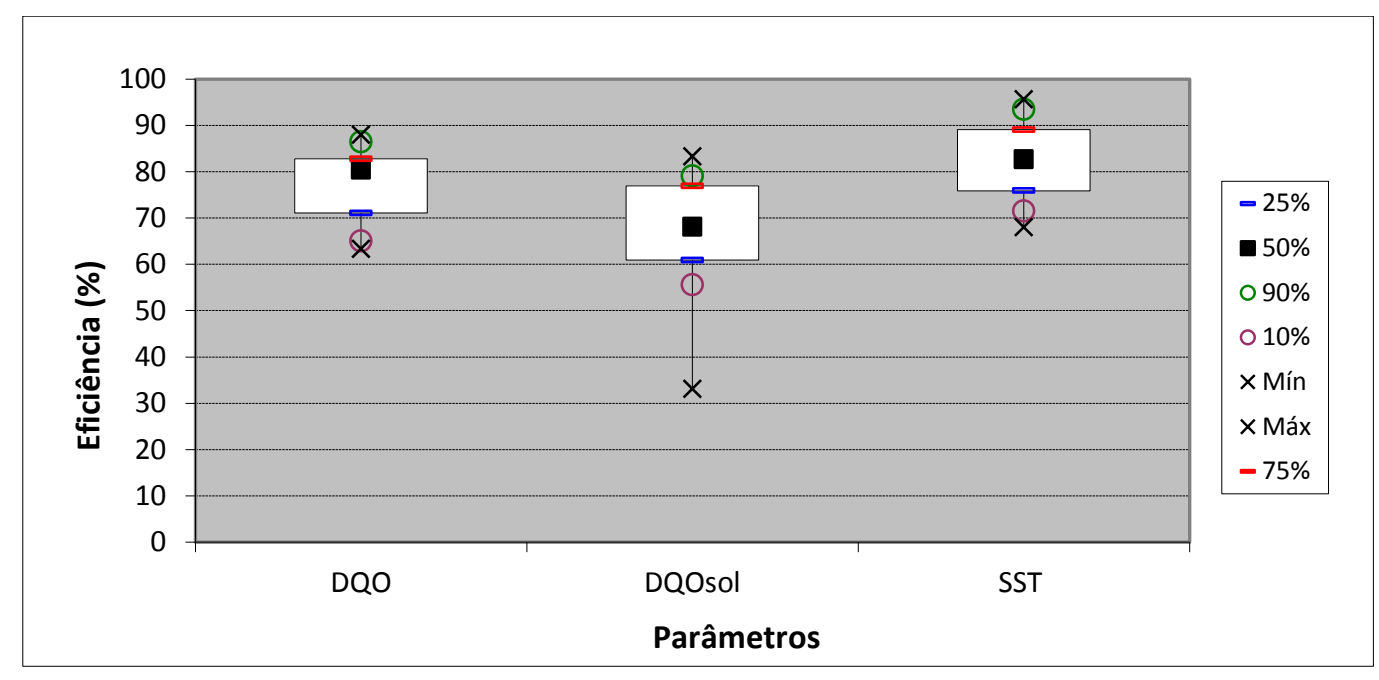

Figura 5.7: Eficiência de remoção de DQO, DQOsol e SST 


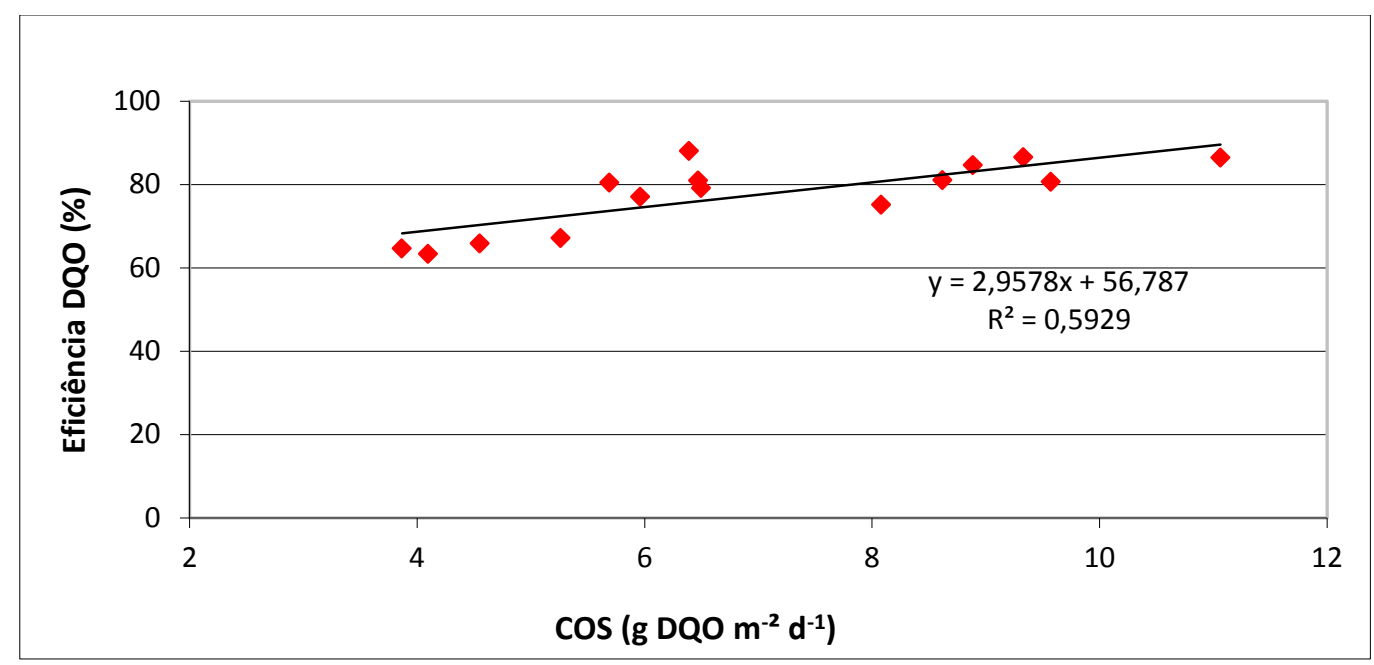

Figura 5.8:Eficiência de DQO versus COS aplicada

Além da melhora da eficiência dos resultados de matéria orgânica e sólidos, houve também um avanço dos resultados de remoção de NTK, acima de $66 \%$ para metade do período de monitoramento (percentil 50), que equivale a uma concentração efluente de $18 \mathrm{mg} \mathrm{L}^{-1}$. No entanto, quando observa-se a eficiência de remoção de $\mathrm{N}-\mathrm{NH}_{4}$, percebe-se que ocorreu uma redução de 71\% na Fase 1.1 (concentração efluente de 5,0 mg L${ }^{-1}$ )para 54\% na Fase 1.2 (concentração efluente igual $12 \mathrm{mg} \mathrm{L}^{-1}$ ). Esse decréscimo do resultados da eficiência de $\mathrm{N}-\mathrm{NH}_{4}$ e NTK da Fase 1.1 para a Fase 1.2 pode serrelacionado com a redução da concentração de $\mathrm{OD}$, de $4,5 \mathrm{mg} \mathrm{L}^{-1}$ para $2,4 \mathrm{mg} \mathrm{L}^{-1}$, respectivamete.

O gráfico da Figura 5.9 apresenta esses resultados da eficiência de N-NH${ }_{4}$ e NTK.

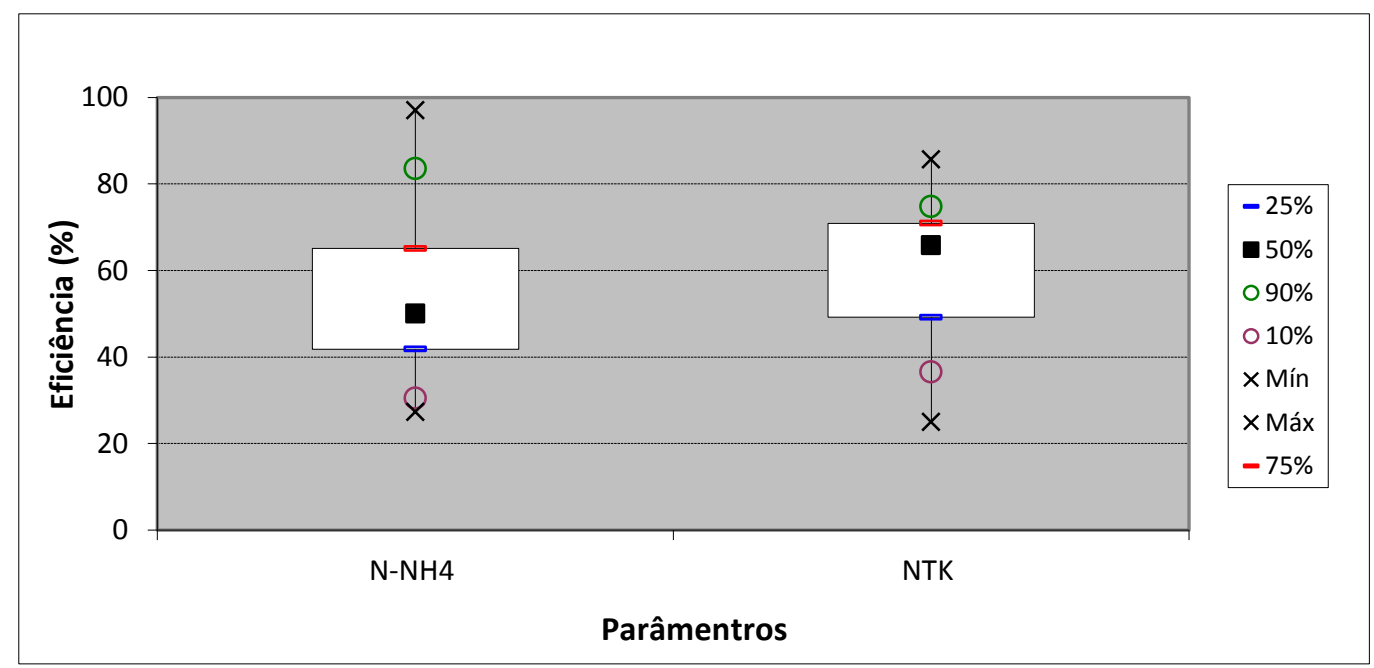

Figura 5.9: Eficiência de remoção de $\mathrm{N}-\mathrm{NH}_{4}$ e NTK

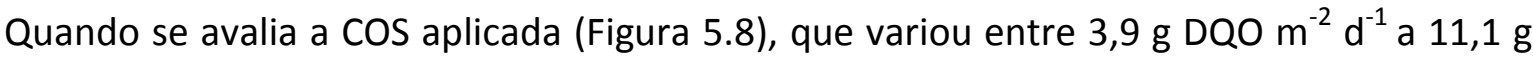
DQO $\mathrm{m}^{-2} \mathrm{~d}^{-1}$ - média igual a 7,0 g DQO $\mathrm{m}^{-2} \mathrm{~d}^{-1}$, e as eficiências de remoção de $\mathrm{N}-\mathrm{NH}_{4}$ (Figura 
5.9); confrontando com oestudo desenvolvido por HEM et al. (1994), no qual indica que para COSmaiores que $5 \mathrm{~g} \mathrm{DBO}_{7} \mathrm{~m}^{-2} \mathrm{~d}^{-1}$ a taxa de nitrificação é quase nula, pode-se indicar que os resultados encontrados nesta fase foram, de certo modo, razoáveis.

O gráfico da Figura 5.10 abaixo ilustra a relação entre a eficiência de remoção de $\mathrm{N}-\mathrm{NH}_{4} \mathrm{e}$ a COS aplicada. Observa-se que, apesar da elevada dispersão dos dados, há uma tendência de que quanto maior a COS aplicada menor a eficiência de remoção de $\mathrm{N}-\mathrm{NH}_{4}$, como esperado. Visto queosmicroganismos heterotróficosse sobressaem dos autotróficos quanto ao metabolismo (VON SPERLING, 1997; METCALF \& EDDY, 2003; JORDÃO \& PESSÔA, 2014).

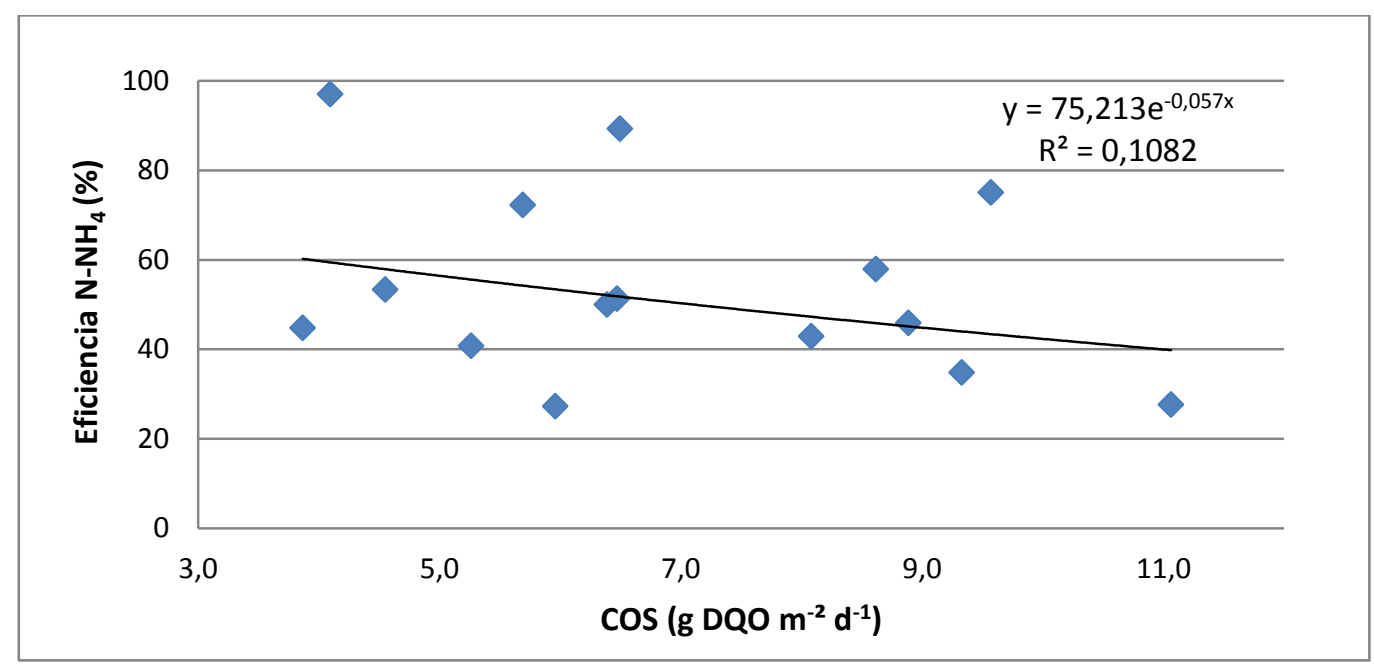

Figura 5.10: Eficiência de remoção de $\mathrm{N}-\mathrm{NH}_{4}$ versus $\mathrm{COS}$ aplicada

Já em relação ao processo de nitrificação, pode-se observar também que a geração média de nitrito e nitrato foi limitada, 1,06 $\mathrm{mg} \mathrm{L}^{-1}$ e 6,16 $\mathrm{mg} \mathrm{L}^{-1}$, respectivamente. Quando avaliase a remoção de NT, nota-se que houve uma remoção média igual a 38\%, considerando a parcela assimilada ao lodo em excesso e aos SST efluente.

Analisando esses resultados juntamente com a emissão de $\mathrm{N}_{2} \mathrm{O}$ no reator, Figura 5.11 abaixo, pode-se indicar que em torno de $37 \%$ do NT foi removido na norma de $\mathrm{N}_{2}$. Uma vez que somente $1,1 \%$ foi removido/emitido como $\mathrm{N}_{2} \mathrm{O}$. 


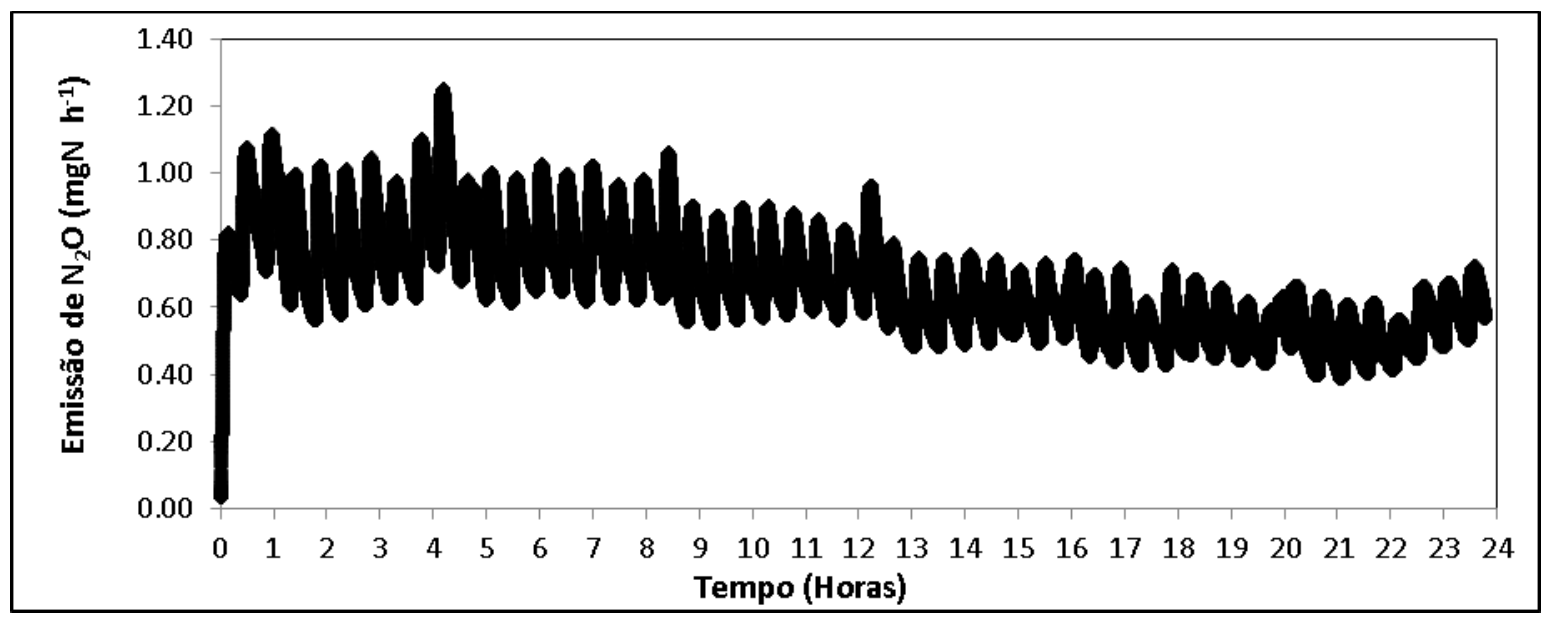

Figura 5.11: Emissão de $\mathrm{N}_{2} \mathrm{O}$ ao longo do período de monitoramento - Fase 1.2

Ainda segundo a Figura 5.11, observa-se que a emissão média $\mathrm{N}_{2} \mathrm{O}$ foi de $0,67 \mathrm{mg} \mathrm{N} \mathrm{h}^{-1}$, alcançando valores de taxa de emissão de aproximadamente $1,25 \mathrm{mg} \mathrm{N} \mathrm{h}^{-1}$.

\subsubsection{Parâmetros Operacionais e de Controle}

Conforme supracitado, a COS se manteve entre 3,9 g DQO $\mathrm{m}^{-2} \mathrm{~d}^{-1}$ a 11,1 $\mathrm{g} \mathrm{DQO} \mathrm{m}^{-2} \mathrm{~d}^{-1}$, com média igual a 7,0 g DQO $\mathrm{m}^{-2} \mathrm{~d}^{-1}$.

No que se refere aos parâmetros operacionais e de controle, obteve-se uma relação $A / M$ da ordem de 5,8 kg DQO kg SSV ${ }^{-1}$ dia $^{-1}$ considerando somente a biomassa em suspensão e igual a 0,29 kg DQO kg SSV ${ }^{-1} \mathrm{dia}^{-1}$ para toda a biomassa (aderida + suspensa). Salienta-se que o aumento da relação $\mathrm{A} / \mathrm{M}$ observada (biomassa em suspensão) entre a Fase 1.1 e 1.2 foi devido ao aumento da concentração média de DQO afluente $324 \mathrm{mg} \mathrm{L}^{-1}$ para 518 $\mathrm{mg} \mathrm{L}^{-1}$,sendo que esse aumento ocorreu pelo fato de manobras realizadas nas elevatórias de esgoto bruto até o CESA.

Ademais, quando se compara a relação A/M (biomassa aderida + suspensa)da Fase 1.1, de 0,5 kg DQO kg SSV ${ }^{-1} \mathrm{dia}^{-1}$ com a dessa fase $\left(0,29 \mathrm{~kg} \mathrm{DQO} \mathrm{kg} \mathrm{SSV}^{-1} \mathrm{dia}^{-1}\right)$, constata-se que houve uma redução, essencialmente devido ao aumento da biomassa aderida.Ou seja, os valores médiosobtidos das biomassaspresentes no reator nesta fase foram iguais a $98,9 \mathrm{~g}$ SST e 75,5 g SSV, das quais aproximadamente $92,5 \%$ estavam aderidos ao meio suporte (91,2 g SST e 69,9 g SSV).

A Tabela 5.4 apresenta os resultados médios para a DBA e os espressos em g SSV m ${ }^{-2}$, indicando também os desvios padrões. Nota-se que os valores obtidos foram estáveis, mostrando que o processo encontrava-se em regime permanente; considerando um 
número de 12 amostras.Realça-se que a relação SSV/SST foi de $72 \%$ para a biomassa em suspensão e $77 \%$ para a biomassa aderida.

Tabela 5.4: Resultados de DBA ( $\mathrm{mg} \mathrm{L}^{-1}$ ) e SSV expresso emg $\mathrm{m}^{-2}$ ao longo da Fase 1.2

\begin{tabular}{cc}
\hline Parâmetro & Valores médios (desvio padrão) \\
\hline DBA $\left(\mathrm{mg} \mathrm{SSV} \mathrm{L}^{-1}\right)$ & $6.995(1.028)$ \\
$\mathrm{g} \mathrm{SSV} \mathrm{m}^{-2}$ & $25,9(3,8)$ \\
\hline
\end{tabular}

Destaca-se que os valores da DBA e da biomassa aderida expressa em $\mathrm{g} \mathrm{SSV} \mathrm{m}^{-2}$ foram superior a todos os reportados pela literatura especializada (MARÍN-PASCUALet al. 2015; 2014 e 2012; LEYVA-DÍAZet al. 2013a; 2013b; ANDREOTTOLA et al. 2003b; HONG-BINet al. 2007; MINEGATTI, 2008 e LUOSTARINENet al. 2006). Esse fato pode ter ocorrido devido a temperatura e/ou a COS aplicada, que nesta pesquisa foram superiores, sabendo que quanto maior a COS e temperatura, maior a produção de lodo e mais acelerado é o metabolismo dos microbiano, até um ponto ótimo (VON SPERLING, 1997; METCALF \& EDDY, 2003; JORDÃO \& PESSÔA, 2014; ØDEGAARD et. al, 1993; RUSTEN et. al, 1995).

Com a elevação da vazão de descarte de lodo (de $0,06 \mathrm{~L} \mathrm{~d}^{-1}$ para $0,17 \mathrm{~L} \mathrm{~d}^{-1}$ ), a idade do lodo reduziu de 57 dias para 27 dias, valor dentro da faixa recomendada no sistema de lodos ativados por aeração prolongada. Da mesma forma que a Fase 1.1, a idade do lodo de 27 dias indica que apenas uma pequena fração do nitrogênio foi assimilada pelos microrganismos. Contudo, o aumento da vazão de descarte de lodo contribui para elevação da eficiência de remoção de SST (média de 60\% - Fase 1.1 para 82\% - Fase 1.2).

A temperatura e o $\mathrm{pH}$ no reator se mantiveram praticamente constantes, variando respectivamente entre 24 e 27 ㄷ e 7,1 e 6,9 para entrada e saída do reator. Ademais, IVL se manteve entre 60 e $110 \mathrm{~mL} \mathrm{~g}^{-1}$.

Houve também o monitoramento da concentração de OD ao longo do experimento de emissão de $\mathrm{N}_{2} \mathrm{O}$, conforme ilustra o gráfico da Figura 5.12, obtendo um valor médio de 2,4 $\mathrm{mg} \mathrm{L}^{-1}$. 


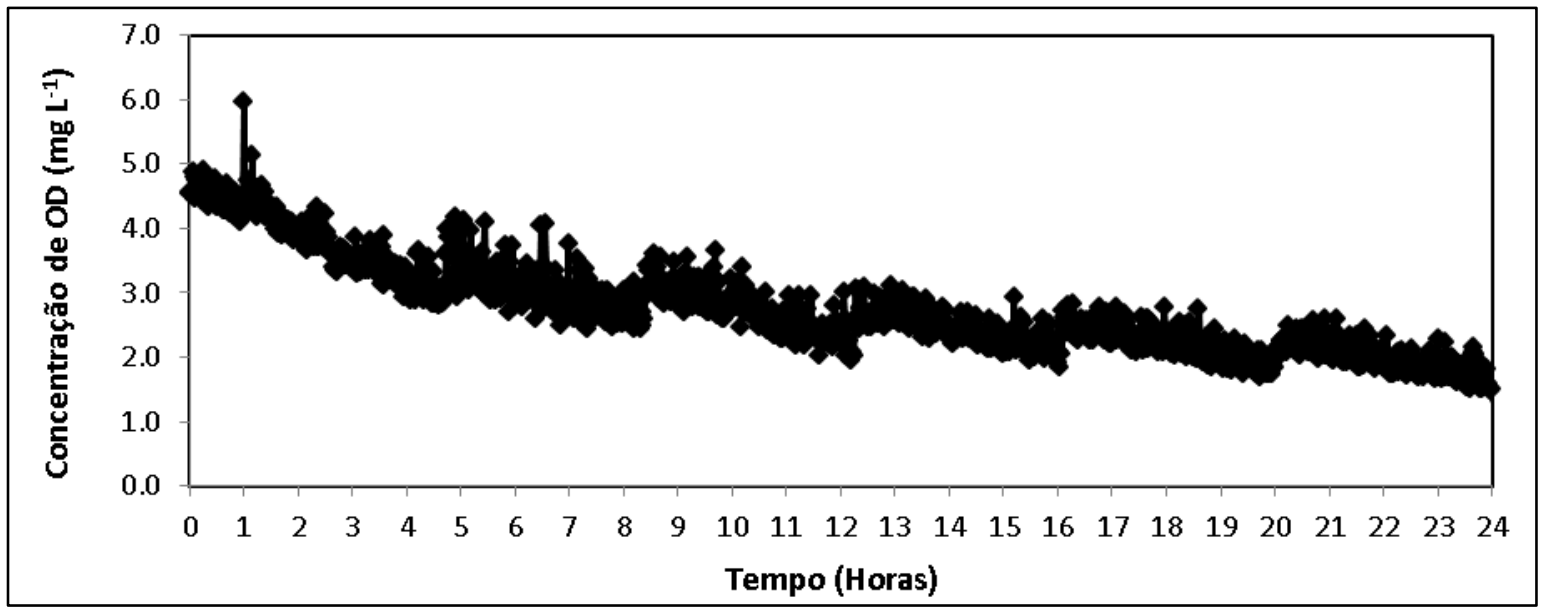

Figura 5.12: Concentração de $\mathrm{OD}$ ao longo do período de monitoramento de $\mathrm{N}_{2} \mathrm{O}$

\subsection{Etapa 2}

\subsubsection{Fase 2.1}

\subsubsection{Análises físico-químicas}

São apresentados, nas Tabelas 5.5a 5.7a seguir, os resultados alcançados na Fase $2.1 \mathrm{em}$ relação as análises físico-químicas para os reatores IFAS 1, IFAS 2 e IFAS 3, respectivamente.

Destaca-se que essa Etapa 2 difere da Etapa 1 quanto a concentração de OD e, principalmente, a elevação do TDH, como explanado anteriormente. 
Tabela 5.5: Resultados do monitoramento doReator IFAS 1 - Fase $2.1\left(\mathrm{mg} \mathrm{L}^{-1}\right.$ )

\begin{tabular}{|c|c|c|c|c|c|c|c|c|c|c|}
\hline \multirow{2}{*}{\multicolumn{2}{|c|}{ Parâmetro }} & \multirow{2}{*}{$\begin{array}{l}\text { № de } \\
\text { dados }\end{array}$} & \multirow{2}{*}{ Média } & \multirow{2}{*}{$\begin{array}{l}\text { Desvio } \\
\text { Padrão }\end{array}$} & \multirow{2}{*}{$\begin{array}{l}\text { Coeficiente } \\
\text { de Variação }\end{array}$} & \multicolumn{5}{|c|}{ Percentis } \\
\hline & & & & & & 10 & 25 & 50 & 75 & 90 \\
\hline \multirow{3}{*}{ DQO } & Afl & 22 & 554 & 192 & 0,35 & 317 & 370 & 552 & 685 & 816 \\
\hline & Efl & 22 & 76 & 41 & 0,54 & 37 & 47 & 66 & 100 & 127 \\
\hline & Ef (\%) & 22 & 85 & 10 & 0,11 & 79 & 83 & 87 & 90 & 94 \\
\hline \multirow{3}{*}{ DQOsol } & Afl & 13 & 132 & 60 & 0,46 & 81 & 85 & 121 & 151 & 195 \\
\hline & Efl & 13 & 42 & 21 & 0,51 & 21 & 23 & 39 & 61 & 71 \\
\hline & Ef (\%) & 13 & 62 & 27 & 0,44 & 20 & 58 & 70 & 80 & 81 \\
\hline \multirow{3}{*}{ DBO } & Afl & 5 & 179 & 22 & 0,12 & 161 & 172 & 179 & 187 & 198 \\
\hline & Efl & 5 & 37 & 12 & 0,32 & 29 & 30 & 34 & 42 & 49 \\
\hline & Ef (\%) & 5 & 78 & 12 & 0,15 & 69 & 75 & 84 & 85 & 85 \\
\hline \multirow{3}{*}{ SST } & Afl & 22 & 335 & 191 & 0,54 & 193 & 217 & 294 & 417 & 635 \\
\hline & Efl & 22 & 39 & 20 & 0,50 & 19 & 23 & 37 & 52 & 62 \\
\hline & $\mathrm{Ef}(\%)$ & 22 & 87 & 7 & 0,09 & 75 & 82 & 88 & 93 & 94 \\
\hline \multirow{3}{*}{ NTK } & Afl & 11 & 38 & 9 & 0,25 & 29 & 30 & 35 & 45 & 46 \\
\hline & Efl & 11 & 20 & 6 & 0,29 & 14 & 15 & 22 & 24 & 25 \\
\hline & Ef (\%) & 11 & 45 & 18 & 0,39 & 24 & 33 & 44 & 56 & 70 \\
\hline \multirow{3}{*}{$\mathrm{N}-\mathrm{NH}_{4}$} & Afl & 18 & 37 & 10 & 0,28 & 24 & 32 & 37 & 44 & 46 \\
\hline & Efl & 18 & 20 & 9 & 0,45 & 10 & 13 & 21 & 25 & 29 \\
\hline & Ef (\%) & 18 & 45 & 26 & 0,57 & 19 & 31 & 47 & 62 & 69 \\
\hline \multirow{2}{*}{$\mathrm{N}-\mathrm{NO}_{2}$} & Afl & 19 & 0,14 & 0,19 & 1,35 & 0,00 & 0,00 & 0,00 & 0,25 & 0,44 \\
\hline & $\mathrm{Efl}$ & 19 & 0,96 & 0,42 & 0,43 & 0,48 & 0,71 & 1,00 & 1,24 & 1,30 \\
\hline \multirow{2}{*}{$\mathrm{N}-\mathrm{NO}_{3}$} & Afl & 19 & 1,4 & 0,81 & 0,58 & 0,78 & 0,85 & 1,20 & 1,45 & 2,42 \\
\hline & Efl & 19 & 7,1 & 3,59 & 0,50 & 1,84 & 5,30 & 6,90 & 9,30 & 11,80 \\
\hline
\end{tabular}

Tabela 5.6: Resultados do monitoramento doReator IFAS 2 - Fase $2.1\left(\mathrm{mg} \mathrm{L}^{-1}\right.$ )

\begin{tabular}{|c|c|c|c|c|c|c|c|c|c|c|}
\hline \multirow{2}{*}{\multicolumn{2}{|c|}{ Parâmetro }} & \multirow{2}{*}{$\begin{array}{l}\text { № de } \\
\text { dados }\end{array}$} & \multirow{2}{*}{ Média } & \multirow{2}{*}{$\begin{array}{l}\text { Desvio } \\
\text { Padrão }\end{array}$} & \multirow{2}{*}{$\begin{array}{l}\text { Coeficiente } \\
\text { de Variação }\end{array}$} & \multicolumn{5}{|c|}{ Percentis } \\
\hline & & & & & & 10 & 25 & 50 & 75 & 90 \\
\hline \multirow{3}{*}{ DQO } & Afl & 12 & 553 & 136 & 0,25 & 424 & 448 & 565 & 634 & 690 \\
\hline & Efl & 12 & 128 & 82 & 0,64 & 50 & 53 & 104 & 181 & 238 \\
\hline & Ef (\%) & 12 & 75 & 16 & 0,22 & 56 & 63 & 78 & 90 & 93 \\
\hline \multirow{3}{*}{ DQOsol } & Afl & 12 & 136 & 61 & 0,45 & 81 & 87 & 123 & 151 & 200 \\
\hline & Efl & 12 & 41 & 33 & 0,80 & 11 & 13 & 27 & 70 & 80 \\
\hline & Ef (\%) & 12 & 68 & 27 & 0,39 & 47 & 61 & 73 & 87 & 93 \\
\hline \multirow{3}{*}{ DBO } & Afl & 4 & 179 & 27 & 0,15 & 158 & 166 & 178 & 192 & 200 \\
\hline & Efl & 4 & 74 & 57 & 0,77 & 31 & 43 & 63 & 100 & 121 \\
\hline & Ef (\%) & 4 & 61 & 16 & 0,42 & 40 & 49 & 65 & 75 & 81 \\
\hline \multirow{3}{*}{ SST } & Afl & 12 & 339 & 148 & 0,44 & 215 & 226 & 295 & 416 & 530 \\
\hline & Efl & 12 & 86 & 64 & 0,74 & 37 & 39 & 45 & 125 & 190 \\
\hline & Ef (\%) & 12 & 70 & 25 & 0,36 & 44 & 59 & 76 & 86 & 94 \\
\hline \multirow{3}{*}{ NTK } & Afl & 3 & 41 & 8 & 0,19 & 36 & 38 & 41 & 43 & 45 \\
\hline & Efl & 3 & 18 & 8 & 0,44 & 14 & 15 & 18 & 21 & 23 \\
\hline & Ef (\%) & 3 & 52 & 29 & 0,56 & 36 & 42 & 52 & 62 & 68 \\
\hline \multirow{3}{*}{$\mathrm{N}-\mathrm{NH}_{4}$} & Afl & 12 & 40 & 11 & 0,27 & 32 & 35 & 40 & 45 & 47 \\
\hline & Efl & 12 & 22 & 13 & 0,59 & 3 & 13 & 24 & 29 & 38 \\
\hline & Ef (\%) & 12 & 46 & 34 & 0,74 & 19 & 27 & 38 & 73 & 89 \\
\hline \multirow{2}{*}{$\mathrm{N}-\mathrm{NO}_{2}$} & Afl & 12 & 0,05 & 0,17 & 3,32 & 0,00 & 0,00 & 0,00 & 0,00 & 0,00 \\
\hline & Efl & 12 & 0,65 & 1,09 & 1,67 & 0,00 & 0,10 & 0,30 & 0,65 & 1,00 \\
\hline \multirow{2}{*}{$\mathrm{N}-\mathrm{NO}_{3}$} & Afl & 12 & 1,27 & 0,45 & 0,35 & 0,80 & 1,00 & 1,30 & 1,40 & 1,50 \\
\hline & Efl & 12 & 5,87 & 5,14 & 0,87 & 1,50 & 2,50 & 3,30 & 8,55 & 11,00 \\
\hline
\end{tabular}


Tabela 5.7: Resultados do monitoramento do Reator IFAS 3 - Fase 2.1 (mg L ${ }^{-1}$ )

\begin{tabular}{|c|c|c|c|c|c|c|c|c|c|c|}
\hline \multirow{2}{*}{\multicolumn{2}{|c|}{ Parâmetro }} & \multirow{2}{*}{$\begin{array}{l}\text { No de } \\
\text { dados }\end{array}$} & \multirow{2}{*}{ Média } & \multirow{2}{*}{$\begin{array}{l}\text { Desvio } \\
\text { Padrão }\end{array}$} & \multirow{2}{*}{$\begin{array}{l}\text { Coeficiente } \\
\text { de Variação }\end{array}$} & \multicolumn{5}{|c|}{ Percentis } \\
\hline & & & & & & 10 & 25 & 50 & 75 & 90 \\
\hline \multirow{3}{*}{ DQO } & Afl & 12 & 553 & 136 & 0,25 & 424 & 448 & 565 & 634 & 690 \\
\hline & Efl & 12 & 145 & 99 & 0,68 & 62 & 80 & 120 & 173 & 220 \\
\hline & $\mathrm{Ef}(\%)$ & 12 & 72 & 19 & 0,26 & 58 & 63 & 72 & 86 & 90 \\
\hline \multirow{3}{*}{ DQOsol } & Afl & 12 & 136 & 61 & 0,45 & 81 & 87 & 123 & 151 & 200 \\
\hline & Efl & 12 & 45 & 37 & 0,84 & 18 & 20 & 33 & 46 & 83 \\
\hline & Ef (\%) & 12 & 69 & 15 & 0,22 & 50 & 58 & 73 & 80 & 84 \\
\hline \multirow{3}{*}{ DBO } & Afl & 4 & 179 & 27 & 0,15 & 158 & 166 & 178 & 192 & 200 \\
\hline & Efl & 4 & 49 & 20 & 0,41 & 33 & 38 & 46 & 58 & 65 \\
\hline & Ef (\%) & 4 & 74 & 7 & 0,10 & 68 & 70 & 74 & 77 & 79 \\
\hline \multirow{3}{*}{ SST } & Afl & 12 & 339 & 148 & 0,44 & 215 & 226 & 295 & 416 & 530 \\
\hline & Efl & 12 & 62 & 39 & 0,63 & 32 & 39 & 50 & 79 & 120 \\
\hline & $\mathrm{Ef}(\%)$ & 12 & 78 & 16 & 0,21 & 64 & 76 & 79 & 87 & 93 \\
\hline \multirow{3}{*}{ NTK } & Afl & 3 & 41 & 8 & 0,19 & 36 & 38 & 41 & 43 & 45 \\
\hline & Efl & 3 & 17 & 7 & 0,43 & 13 & 15 & 17 & 20 & 21 \\
\hline & Ef (\%) & 3 & 55 & 27 & 0,49 & 40 & 45 & 55 & 64 & 70 \\
\hline \multirow{3}{*}{$\mathrm{N}-\mathrm{NH}_{4}$} & Afl & 12 & 40 & 11 & 0,27 & 32 & 35 & 40 & 45 & 47 \\
\hline & Efl & 12 & 25 & 11 & 0,45 & 11 & 18 & 29 & 33 & 37 \\
\hline & $\mathrm{Ef}(\%)$ & 12 & 39 & 23 & 0,61 & 18 & 21 & 38 & 51 & 70 \\
\hline \multirow{2}{*}{$\mathrm{N}-\mathrm{NO}_{2}$} & Afl & 12 & 0,05 & 0,17 & 3,32 & 0,00 & 0,00 & 0,00 & 0,00 & 0,00 \\
\hline & Efl & 12 & 1,05 & 0,99 & 0,94 & 0,20 & 0,25 & 0,85 & 1,35 & 2,70 \\
\hline \multirow{2}{*}{$\mathrm{N}-\mathrm{NO}_{3}$} & Afl & 12 & 1,27 & 0,45 & 0,35 & 0,80 & 1,00 & 1,30 & 1,40 & 1,50 \\
\hline & Efl & 12 & 6,61 & 4,12 & 0,62 & 3,00 & 3,55 & 6,30 & 8,15 & 11,10 \\
\hline
\end{tabular}

Inicialmente, observando os dados obtidos pelo Reator IFAS 1 (Tabela 5.5), nota-se que as eficiências médias de DQO, DQOsol e DBO foram de $85 \%, 62 \%$ e $78 \%$, alcançando valores de94\%, 81\% e 85\%, (percentil 90), respectivamente. Já para o Reator IFAS 2 (Tabela 5.6), observa-se que a eficiência média de DQO foi de $75 \%$, de DQOsol igual a $68 \%$ e de DBO equivalente a $62 \%$,obtendo valores da ordem de 93\%, 93\%, 81\% (percentil 90) para DQO, DQOsol, DBO, respectivamente. Por fim, quando se analisa os dados da Tabela 5.7 para remoção de DQO, DQOsol e DBO, percebe-se que as eficiências médias foram iguais a, respectivamente, $72 \%, 69 \%, 74 \%$, com percentil de 90 equivalentes a $90 \%, 84 \%, 79 \%$.

Diante disso, pode-se verificar queo reator IFAS $1\left(\mathrm{OD}=2,0 \mathrm{mg} \mathrm{L}^{-1}\right.$ ) obteve eficiência de remoção de matéria orgânica superior aos reatores IFAS $2\left(O D=1,0 \mathrm{mg} \mathrm{L}^{-1}\right)$ e IFAS $3(O D=$ $1,5 \mathrm{mg} \mathrm{L}^{-1}$ ), e os reatores IFAS 2 e 3 obtiveram eficiências remoção de matéria orgânica similares, indicando que o OD pode ter sido um fator limitante. O gráfico da Figura 5.13 ilustra o comportamentodas eficiências de remoção DQO, DQOsol e DBO nos três reatores. 


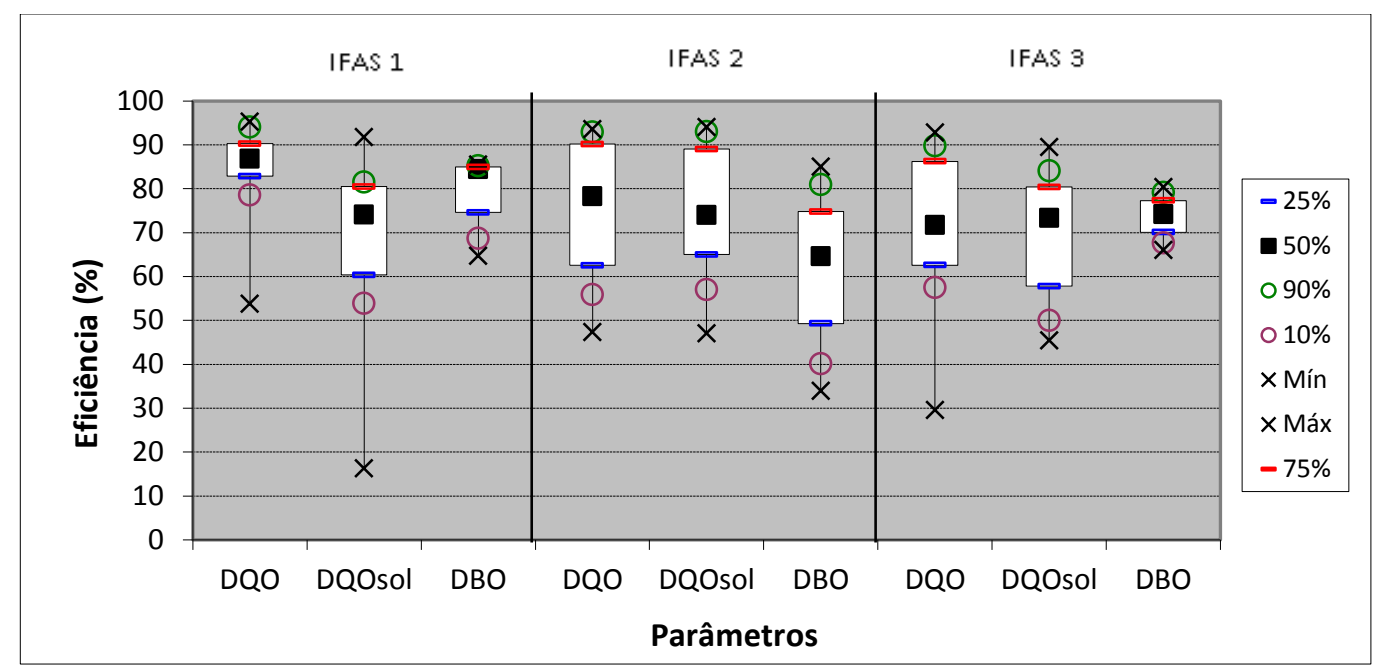

Figura 5.13: Eficiência de remoção de DQO, DQOsol e DBO - IFAS 1, 2 e 3

Ademais, é importante ressaltar que, por vezes, os reatores apresentavam um aspecto opaco. Assim, foi-se investigar o motivo para tal acontecimento, podendo ser problemas com o sistema de aeração, substâncias tóxicas presentes no esgoto, etc.

Ocorre que, durante uma análise de DBO, verificou-se elevada salinidade, usalmente expressa em termos de cloretos $\left(\mathrm{mg} \mathrm{Cl}^{-1}\right)$, que interferesobremaneira na técnica analítica para determinação da DBO e DQO e, é claro, no processo biológico como um todo.Sabe-se que paraconcentrações de cloretos acima de $2.000 \mathrm{mg} \mathrm{Cl}^{-1} \mathrm{~L}^{-1}$ afeta o transporte de substâncias químicas entre o meio e o interior celular, provocando mudanças no metabolismo microbiológico, tendendo a causar desidratação e lise celulare, consequentemente, depreciçãoda remoção de matéria orgânica e compostos nitrogenados (COSTA, 2014; WANDERLEY, 2013; DEORSOLA, 2006).

Neste contexto, os gráficos das Figuras 5.14 a 5.16 apresentam a série histórica das concentrações de DQO afluente e efluente e sua eficiência, indicando os eventos de salinidades sucedidos (dia 79IFAS 1 edia 2IFAS 2 e 3 - salinidade igual a $2.749 \mathrm{mg} \mathrm{Cl}^{-1} \mathrm{e}$ dia 106 IFAS 1 edia 29 IFAS 2 e 3 - salinidade $3.357 \mathrm{mg} \mathrm{Cl}^{-1}{ }^{-1}$ ). 


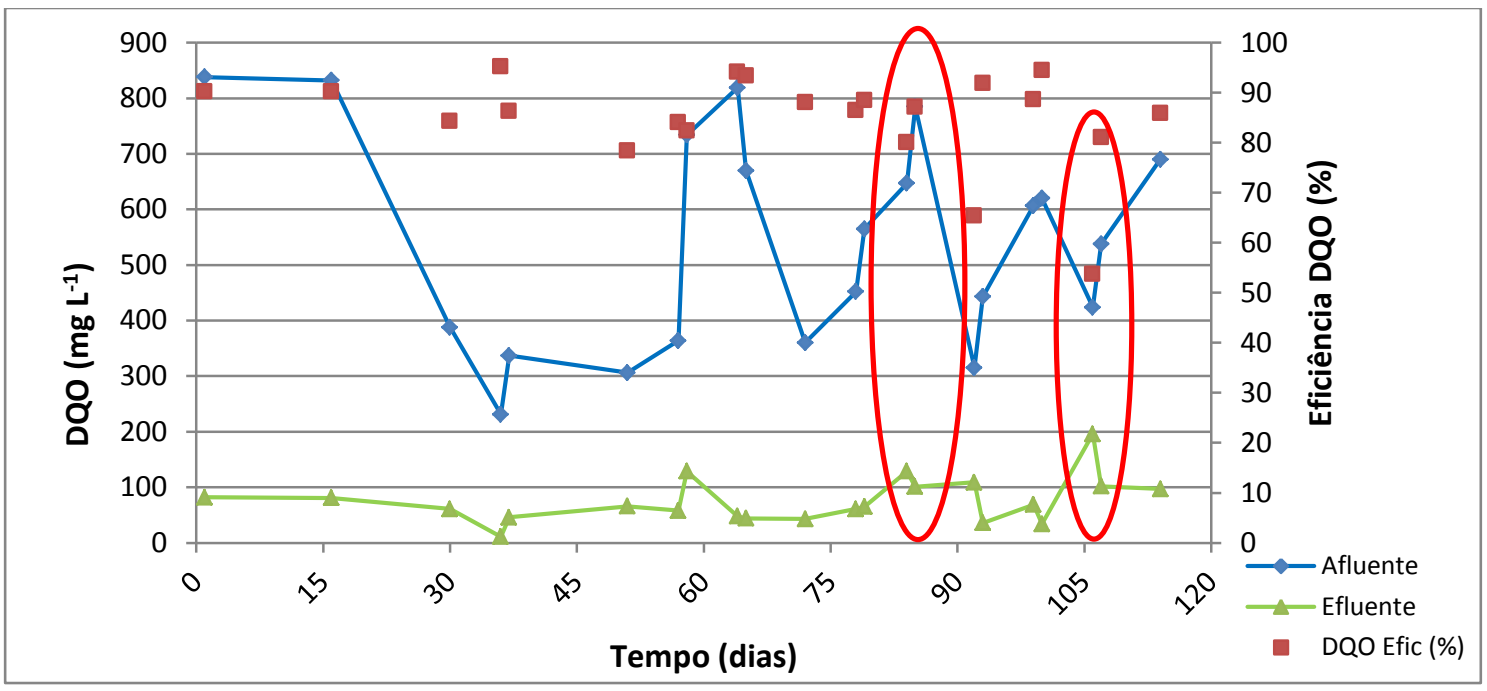

Figura 5.14:DQO afluente e efluente e eficiência DQO - IFAS 1

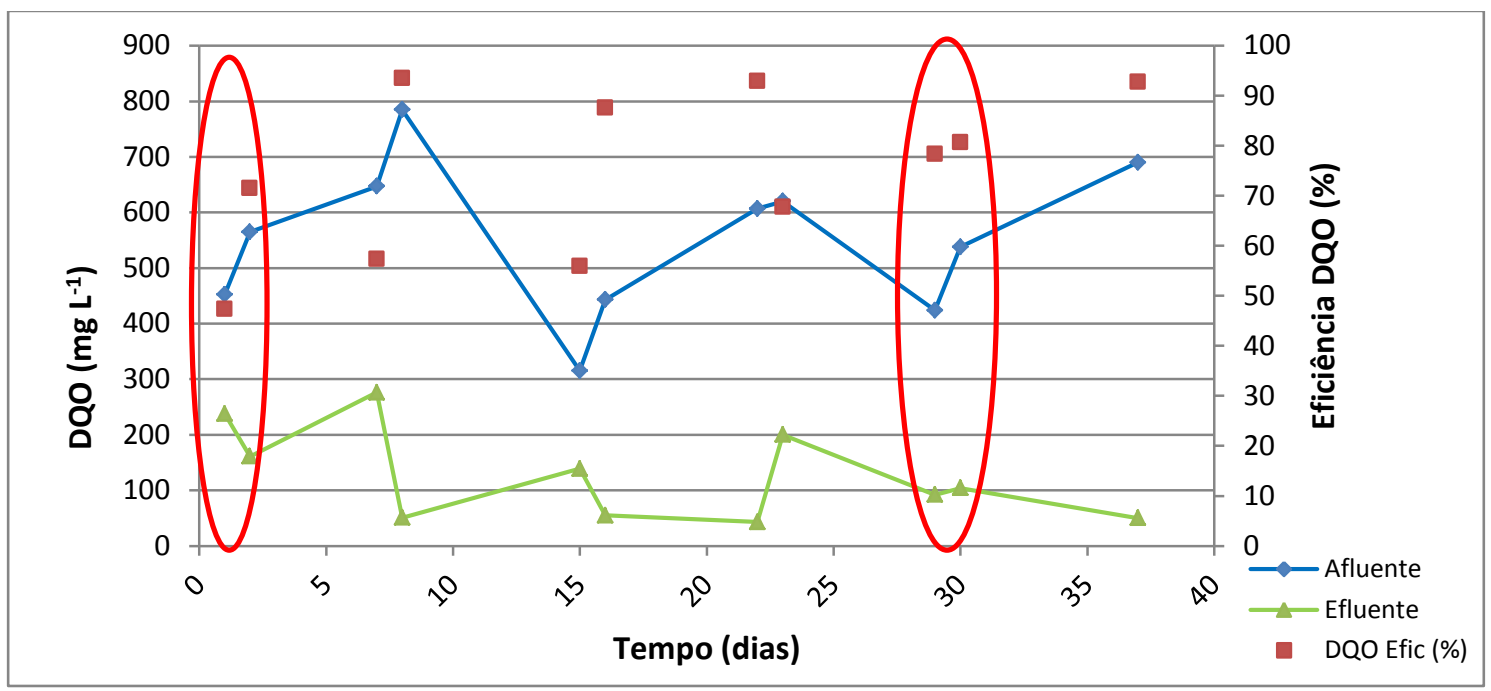

Figura 5.15: DQO afluente e efluente e eficiência DQO - IFAS 2

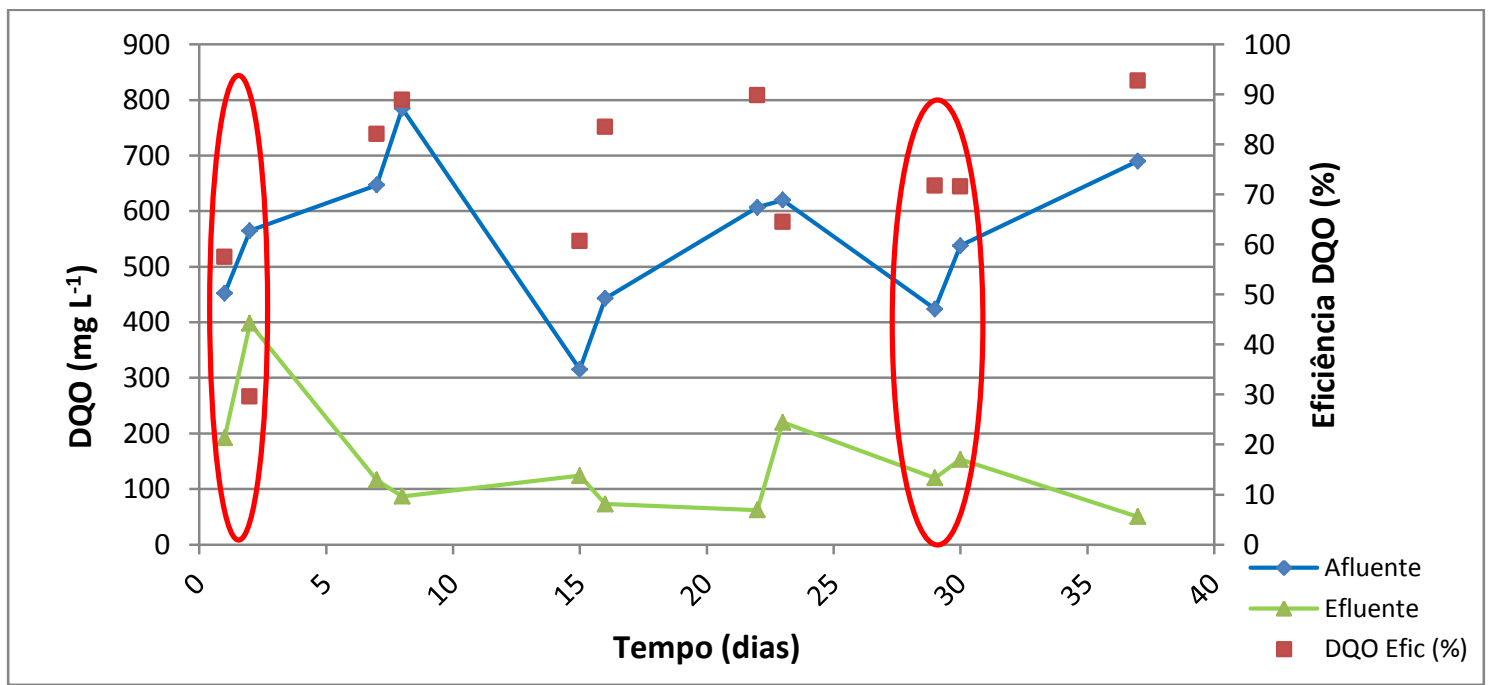

Figura 5.16: DQO afluente e efluente e eficiência DQO - IFAS 3 
Percebe-se que, quando ocorreram esses eventos, houve um distubionas eficiências de remoção de DQO, principalmente no reator IFAS 1.

De qualquer forma, mesmo com toda variabilidade dos dados e com o choque de salinidade, os gráficos das Figuras 5.17 a 5.19 ilustram que, de certa maneira, quanto maior a COS aplicada maior a eficiência de remoção de DQOobtida em todos os reatores.

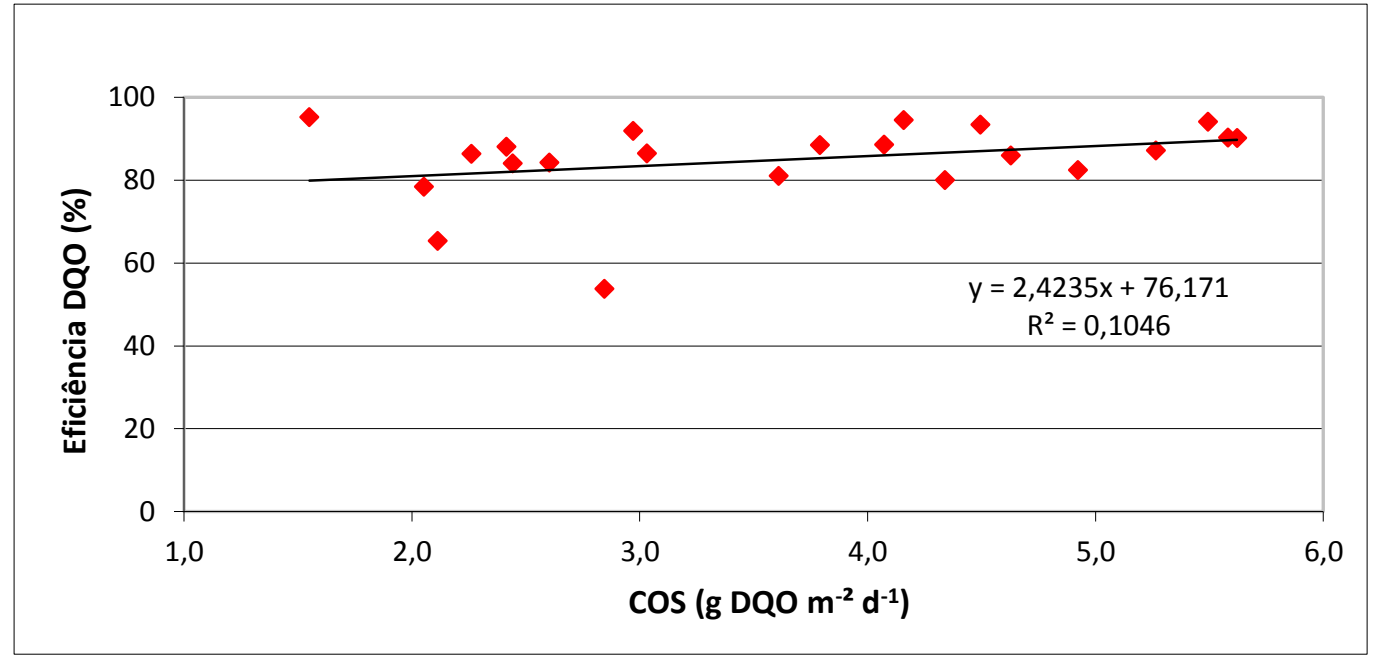

Figura 5.17: Eficiência de DQO versus COS aplicada - IFAS 1

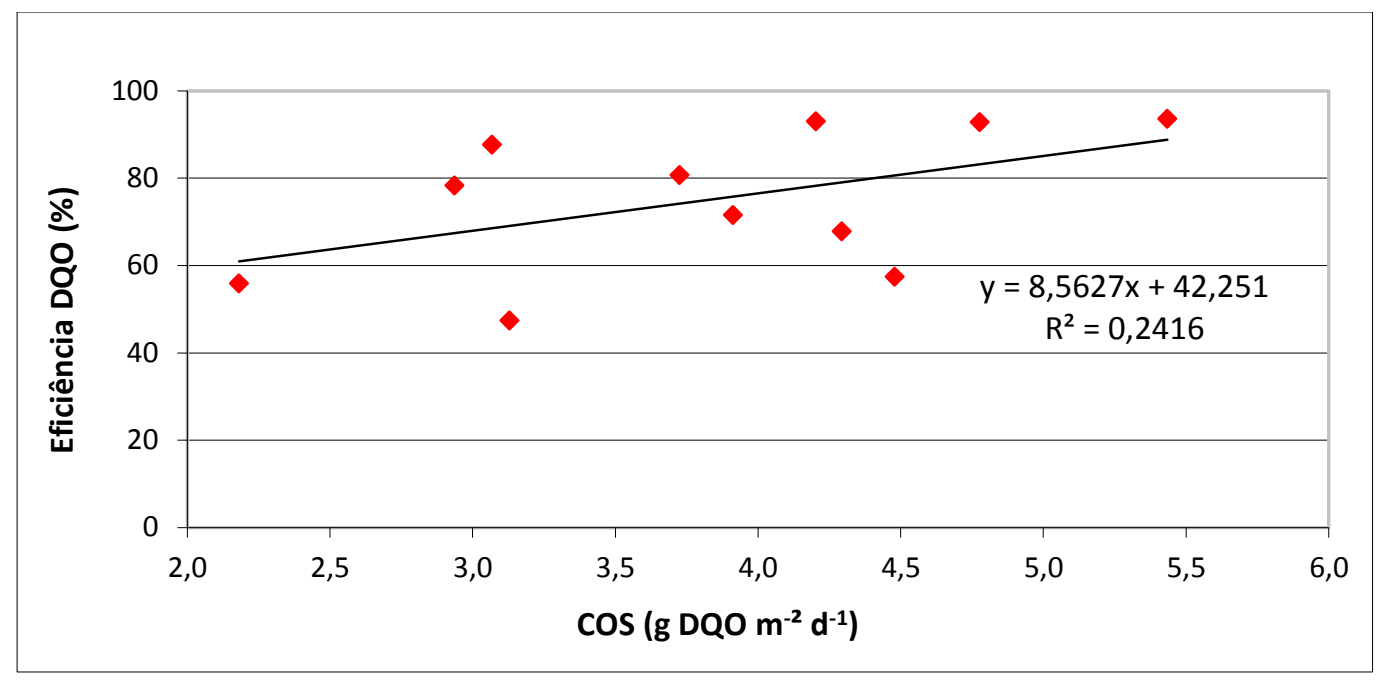

Figura 5.18: Eficiência de DQO versus COS aplicada - IFAS 2 


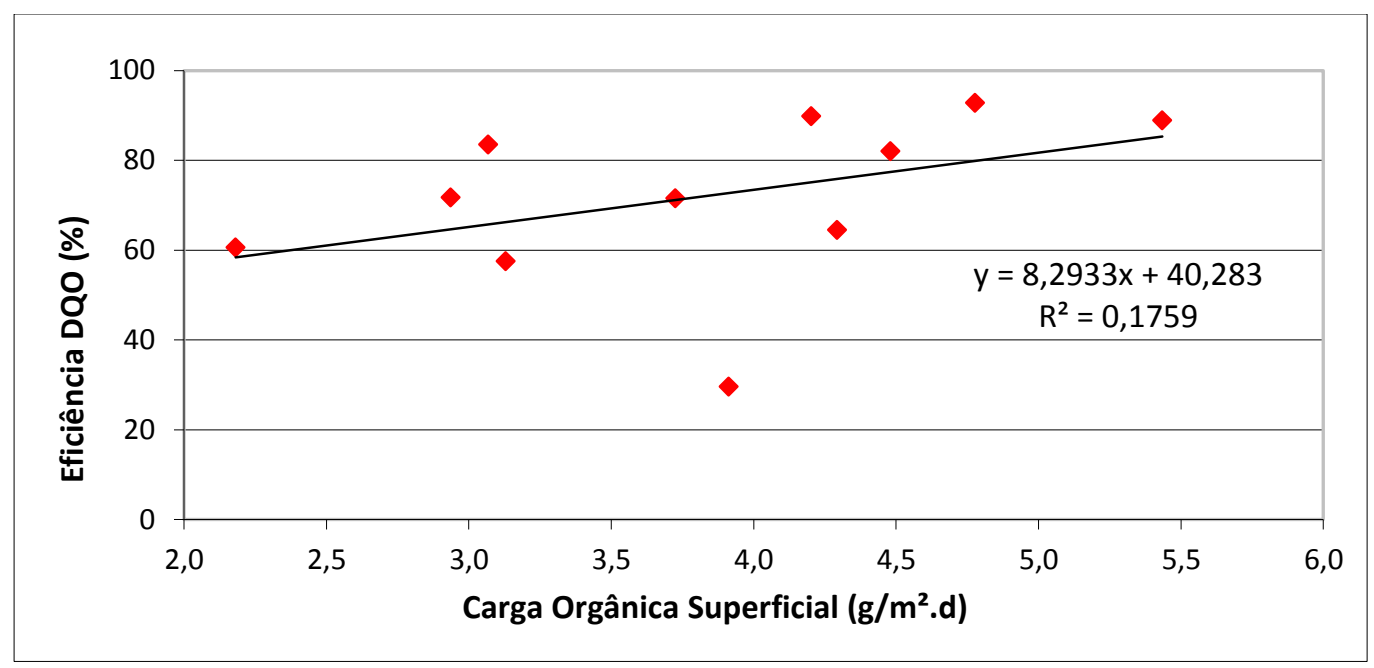

Figura 5.19: Eficiência de DQO versus COS aplicada - IFAS 3

Ainda nesse enredo, quando se avalia a remoção média de $\mathrm{N}-\mathrm{NH}_{4} \mathrm{e}$ o choque de salinidade nos reatores, observa-se por meio dos gráficos das Figuras 5.20 a 5.22 que o impacto sobre os microrganismos nitrificantes foi muito maior, alcançando valores para os reatores IFAS 1, IFAS 2 e IFAS 3 igual a $31 \%$ e $-15 \% ; 31 \%$ e $-18 \%$; e $55 \%$ e $4 \%$, respectivamente.

De fato, a biomassa nitrificante, principalmente as bactérias nitritantes, apresentam elevada sensibilidade à presença de sais, como o íon cloreto, ainda mais quando o choque salino ocorre em um curto intervalo de tempo; necessitando consequentemente de um elevado período de residência celular para o retorno da atividade de nitrificação (LUDZACK E NORAN, 1965 apudCOSTA, 2014).

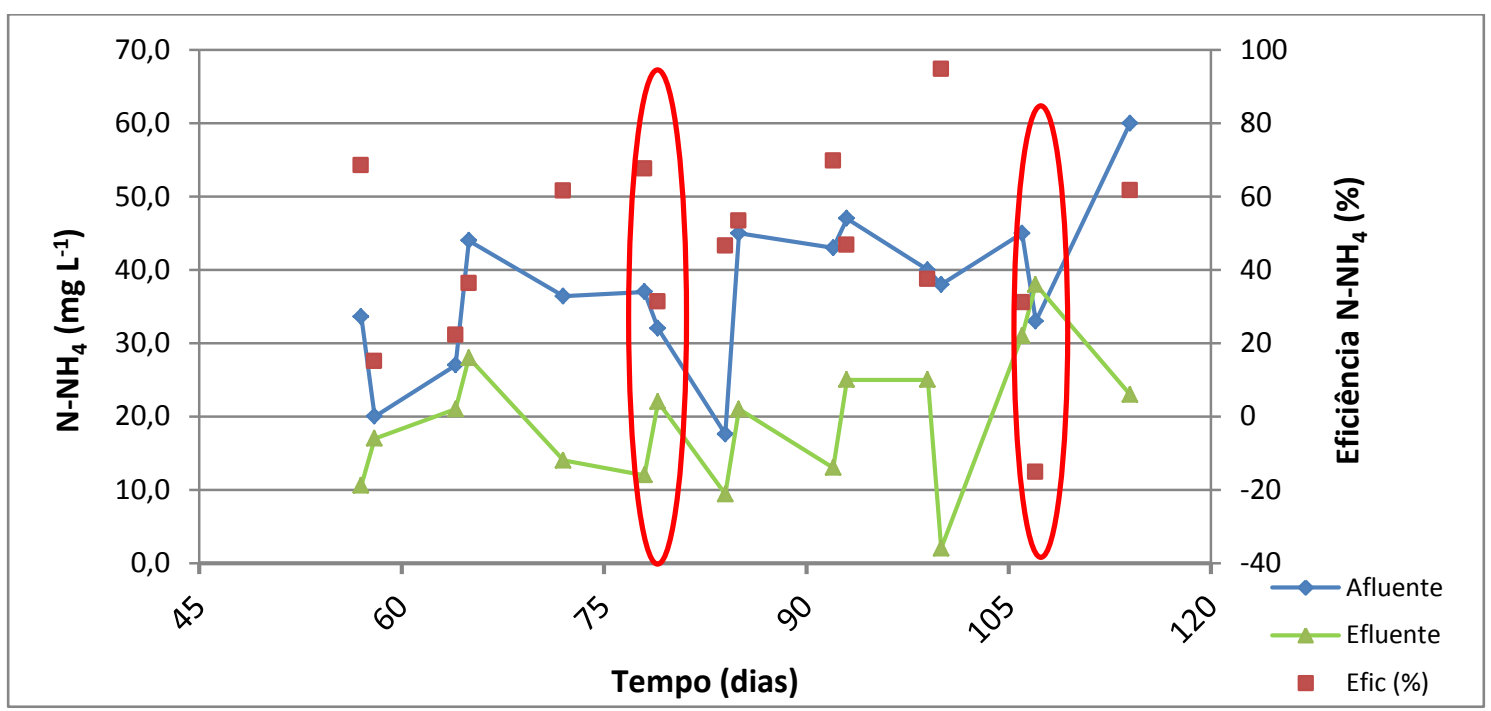

Figura 5.20: $\mathrm{N}-\mathrm{NH}_{4}$ afluente e efluente e eficiência $\mathrm{N}-\mathrm{NH}_{4}-$ IFAS 1 


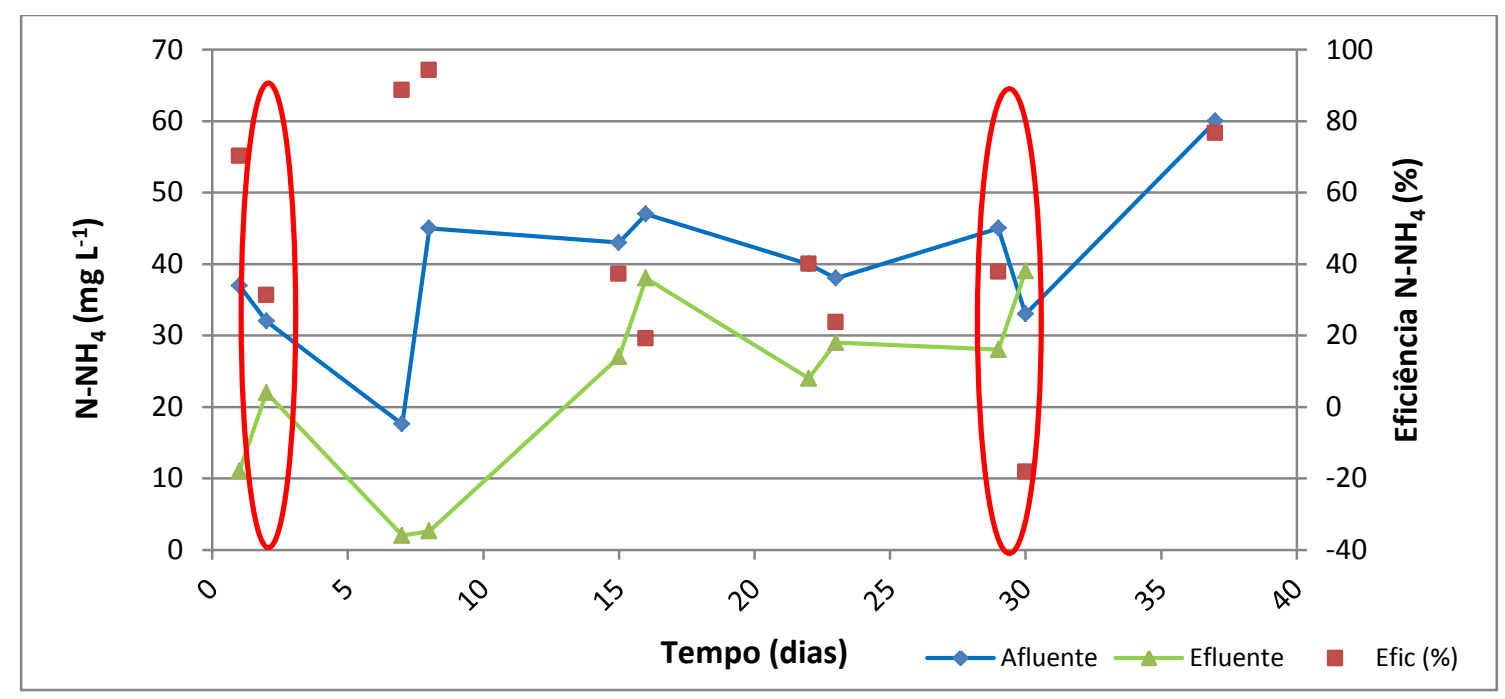

Figura 5.21: $\mathrm{N}-\mathrm{NH}_{4}$ afluente e efluente e eficiência $\mathrm{N}-\mathrm{NH}_{4}-$ IFAS 2

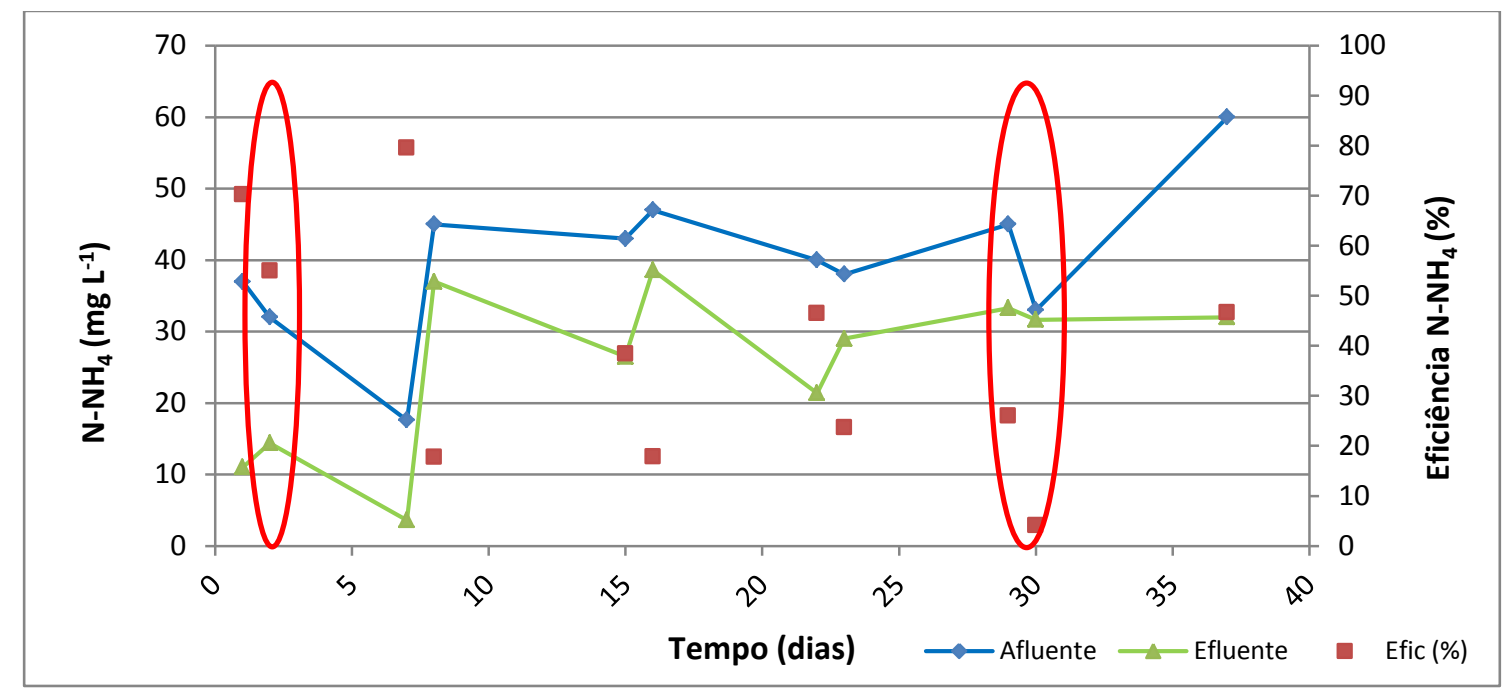

Figura 5.22: $\mathrm{N}-\mathrm{NH}_{4}$ afluente e efluente e eficiência $\mathrm{N}-\mathrm{NH}_{4}-$ IFAS 3

Os gráficos das Figuras 5.23 a 5.25 ilustram a relação entre a eficiência de remoção de N$\mathrm{NH}_{4}$ e a COS aplicada. 


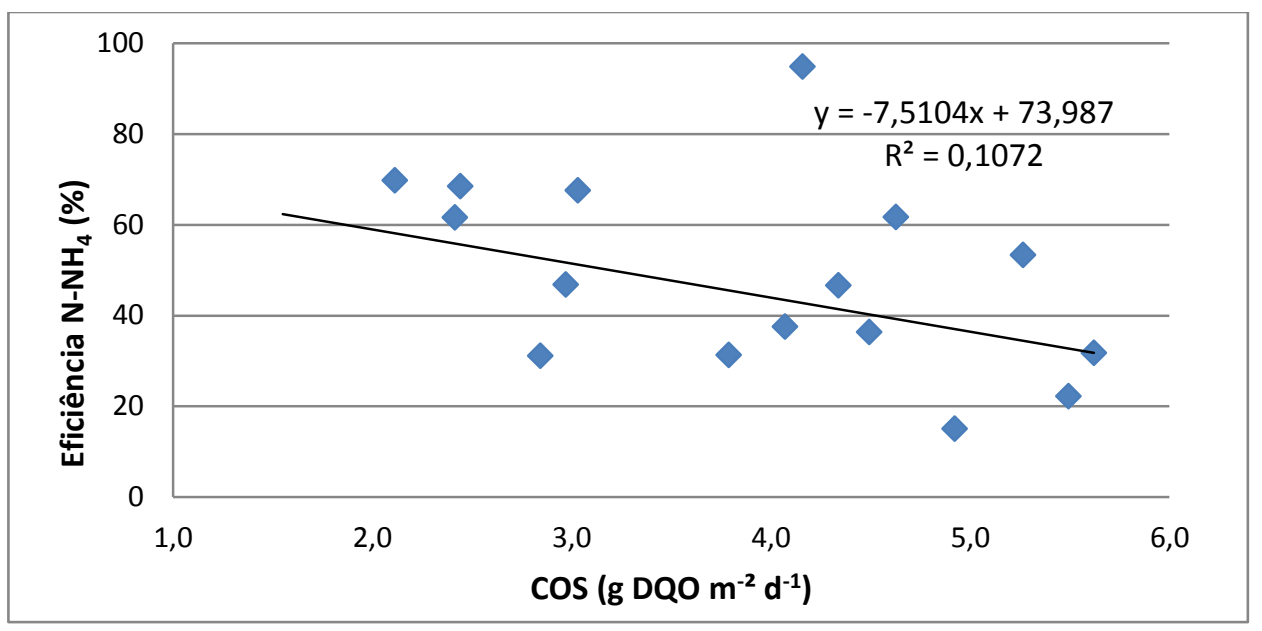

Figura 5.23: Eficiência de remoção de $\mathrm{N}-\mathrm{NH}_{4}$ versus COS aplicada - IFAS 1

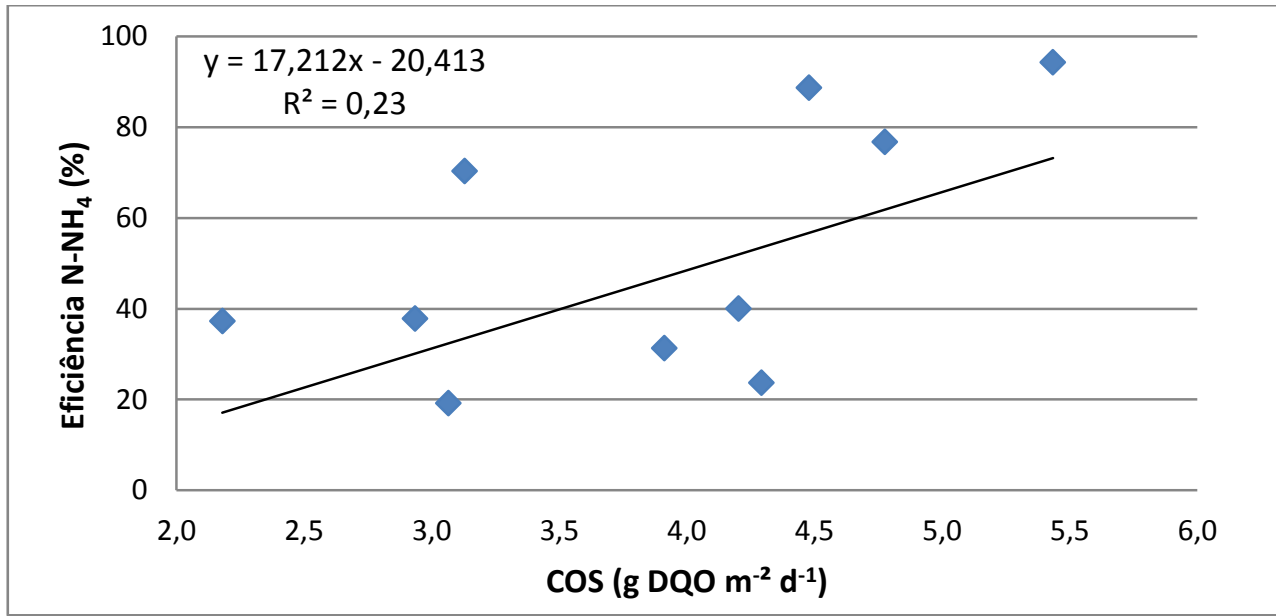

Figura 5.24: Eficiência de remoção de $\mathrm{N}-\mathrm{NH}_{4}$ versus COS aplicada - IFAS 2

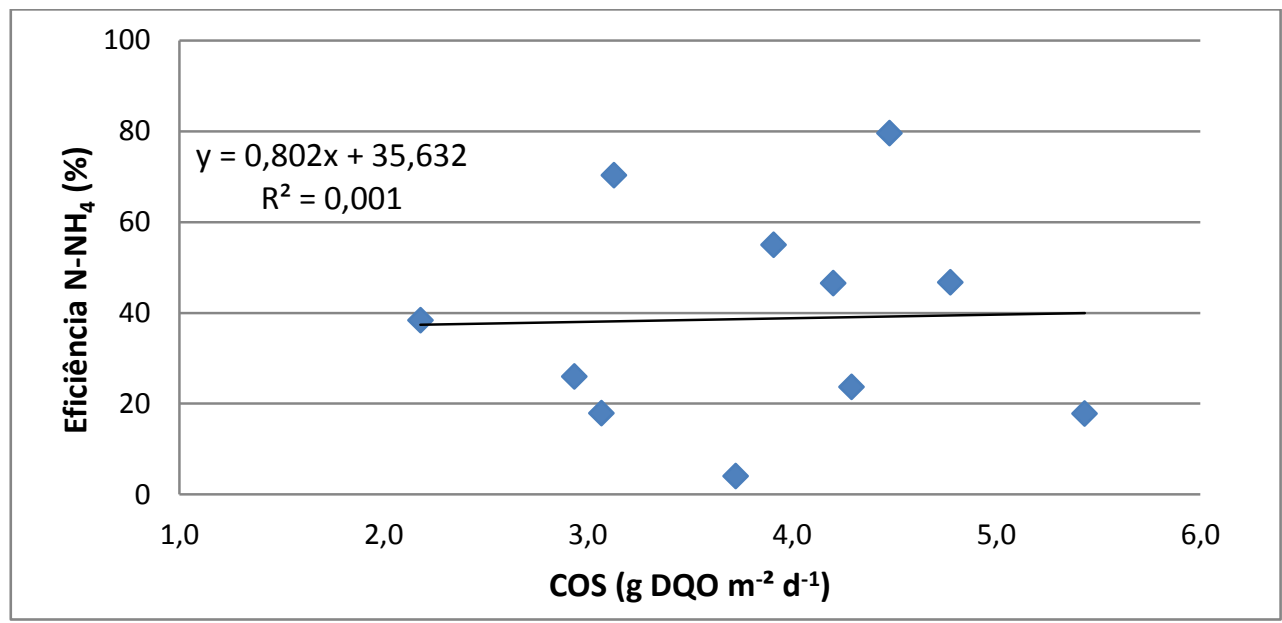

Figura 5.25: Eficiência de remoção de $\mathrm{N}-\mathrm{NH}_{4}$ versus COS aplicada - IFAS 3

Observa-se que, com exceção do reator IFAS 2, quanto maior a COS aplicada menor a eficiência de remoção de $\mathrm{N}-\mathrm{NH}_{4}$ e/ou mais elevada foi a dispersão dos dados.Salienta-se que, a única explicação plausível para esse comportamente do reator IFAS 2 é a questão 
da quantidade e/ou qualidade da biomassa nitrificante presente, que, de fato, foi o reator que obteve desempenho levemente melhor quanto a remoção de $\mathrm{NTK}$ e $\mathrm{N}-\mathrm{NH}_{4}$.

Especificamente em relação a nitrificação, nota-se que a remoção média de $\mathrm{N}-\mathrm{NH}_{4}$ foi da ordem de $45 \%$ e a conversão a $\mathrm{N}-\mathrm{NO}_{3}$ efluente em relação a concentração afluente foi cerca de 7 vezes para o reator IFAS 1, sendo que praticamente não houve variação de N$\mathrm{NO}_{2}$. Esse comportamente foi também observado para os reatores IFAS 2 e IFAS 3. Isto é, o processo de nitrificação foi bastante restrito, podendo ser inferido pela limitada disponibilidade de OD nos reatores e/ou pela salinidade.

\subsubsection{Parâmetros Operacionais e de Controle}

Foram monitorados os principais parâmetros operacionais e de controle, conforme apresenta a Tabela 5.8 .

Tabela 5.8: Resultados dos principais parâmetros operacionais e de controle - Fase 2.1

\begin{tabular}{|c|c|c|c|}
\hline Parâmetros & Reator IFAS 1 & Reator IFAS 2 & Reator IFAS 3 \\
\hline $\mathrm{A} / \mathrm{M}\left(\mathrm{kg} \mathrm{DQO} \mathrm{kg} \mathrm{SSV}^{-1} \mathrm{~L}^{-1}\right)$ & $8,6^{4}\left(0,21^{1}\right)$ & $4,85^{4}\left(0,27^{1}\right)$ & $5,16^{4}\left(0,27^{1}\right)$ \\
\hline $\cos \left(g \mathrm{DQO} \mathrm{m}^{-2} \mathrm{~d}^{-1}\right)$ & $3,6\left(1,26^{2}\right)$ & $3,8\left(0,90^{2}\right)$ & $3,8\left(0,90^{2}\right)$ \\
\hline DBA (mg SSV L L & $6.639\left(2.092^{2}\right)$ & $3.951\left(2.416^{2}\right)$ & $6.684\left(4.491^{2}\right)$ \\
\hline Biomassa aderida $\left(\mathrm{g} \mathrm{m}^{-2}\right)$ & $24,6\left(7,75^{2}\right)$ & $7,3\left(4,5^{2}\right)$ & $12,4\left(8,3^{2}\right)$ \\
\hline SSVTA (mg SSV L ${ }^{-1}$ ) & 170 & 434,2 & 223,0 \\
\hline $\mathrm{SSV} / \mathrm{SST}^{3}(\%)$ & $70 ; 81$ & $74 ; 76$ & $75 ; 73$ \\
\hline Idade do Lodo (dias) & 15 & 13 & 12 \\
\hline pH (entrada - saída) & $7,2-7,0$ & $7,2-6,9$ & $7,2-7,0$ \\
\hline Temperatura $(\stackrel{\circ}{ } \mathrm{C})$ & 23,7 a 26,6 & 23,7 a 26,6 & 23,7 a 26,6 \\
\hline $\mathrm{IVL}\left(\mathrm{mL} \mathrm{g}^{-1}\right)$ & 90a130 & 90 a 130 & 90 a 130 \\
\hline
\end{tabular}

\footnotetext{
${ }^{1}$ Biomassa total (aderida + suspensa)

${ }^{2}$ Desvio Padrão

${ }^{3}$ SSV/SST em suspensão; SSV/SST aderido

${ }^{4}$ Somente Biomassa em suspensão
}

Com relação aos valores de $\mathrm{A} / \mathrm{M}$, observa-se que os valores obtidos nos reatores IFAS 2 e 3 foram bem inferiores ao encontrado no reator IFAS 1, considerando somente a biomassa em suspensão, dada pela maior concentração de biomassa em suspensão. Quando avaliase considerando a biomassa total, nota-se que o valor de A/M para o reator IFAS 1 foi 
menor, principalmente devido a elevada biomassa aderida, igual a $6.639 \mathrm{mg} \mathrm{SSV} \mathrm{L}^{-1}(24,6$ gSSV $\mathrm{m}^{-2}$.

Outro ponto importante que pode ser destacado, é que razão $A / M$ considerando a biomassa total foram inferioes a 0,3 kg DQO kg SSV-1 L-1 para todos os reatores e, iguais para os reatores IFAS 2 e 3 . Sendo que, esses valores alcançados nos reatores IFAS 2 e 3 foram similares devido a diferença entre a biomassa aderida e em suspensão. Isto é, no reator IFAS 2 a baixa DBA obtida (3.951 mg SSV L-1) foi compensada pela maior concentração de SSVTA (434,2 mg SSV L-1), já no reator IFAS 3 ocorreu o inverso, a elevada DBA obtida (6.684 mg SSV L-1) contrabalançou com a menor concentração de SSVTA (223,0 mg SSV L-1).

Salienta-se que essa diferença entre a DBA nos dois reatores pode ser em virtude da maior concentração de OD no reator IFAS 3 dada que a COS aplicada e a Idade do Lodo foram semelhantes.

De qualquer maneira, destaca-se que os valores da DBA para o reator IFAS 1 foram superiores aos reportados pela literatura (Marín-Pascual et al. 2015; 2014 e 2012; LeyvaDíazet al. 2013a; 2013b; Andreottola et al. 2003b; Hong-Binet al. 2007; Minegattil, 2008 e LUOSTARINEN et al. 2006), podendo ser justificado devido a temperatura e/ou a COS aplicada, que nesta pesquisa foram superiores aos demais estudos e que nos reatores IFAS 2 e 3 foram inferiores, provavelmente, devido a baixa concentração de OD.

Ainda sobre a Tabela 5.8, percebe-se que a relação SSV/SST, a temperatura, o pH e o IVL se mantiveram praticamente iguais em todos os reatores;com exceção da relação SST/SSV do reator IFAS 1 para a biomassa aderida,que foi ligeiramentealta, equivalente a 0,81, podendo ser explicado pela maior concentração de OD no tanque.

Pode-se constatar também que a COS média dos três reatores foram similares, de 3,6 $\mathrm{g}$ DQO $\mathrm{m}-2 \mathrm{~d}-1$ para o IFAS 1 e de 3,8 g DQO m-2d-1 para o IFAS 2 e IFAS 3.

Quanto a concentração de OD nos reatores IFAS 2 e 3, as Figuras 5.26 e 5.27 ilustram a tela do computador demostrandosua variação,detalhando a linha de OD média igual a 1,0 mg L-1 e de 1,5 mg L-1, respectivamente. Sendo que esse sistema também foi utilizado durante Fase 2.2, conforme relatado anteriormente. 


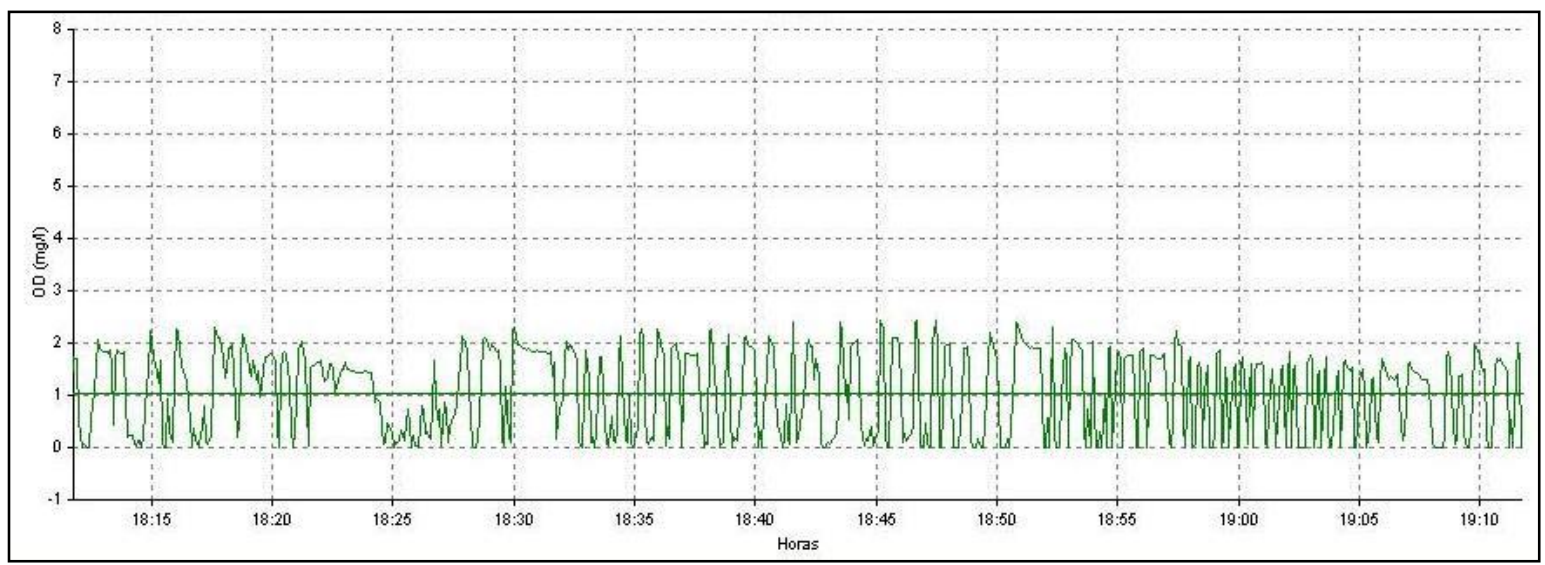

Figura 5.26:Tela do computador indicando OD médio no IFAS 2 - Fase 2.1

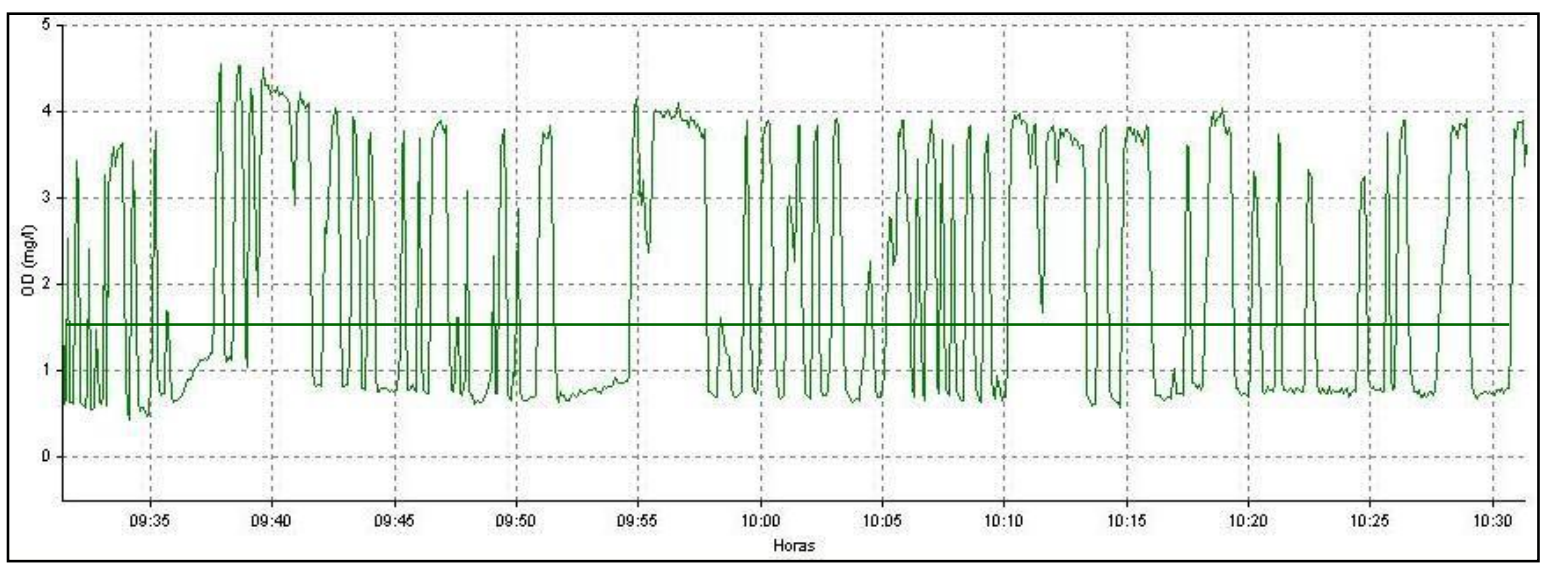

Figura 5.27:Tela do computador indicando OD médio no IFAS 3 - Fase 2.1

Éimportante realçar que, em razão da limitada remoção de nitrogênio, dos choques de salinidade e pela indisponibilidade do equipamento de $\mathrm{N}_{2} \mathrm{O}$,aanálise de emssão de $\mathrm{N}_{2}$ Onãofoi realizada.

\subsubsection{Fase 2.2}

Nesta fase,os 3 reatores foram igualmente utilizados. Sendo que nos IFAS 2 e IFAS 3trabalhou-se com efluente sintético,devidoaos choques de salinidade ocorridos na Fase 2.1,e no reator IFAS 1 a concentração de OD foi reduzida para $1,5 \mathrm{mg} \mathrm{L}^{-1}$ a fim de equiparar sua performance, especificamente, com ado reator IFAS 3. O TDH foi mantido o mesmo da Fase 2.1, igual a 11horas.

É importante salientar que, após aproximadamente 1 mês de monitoramento (25/08/2015), houve uma queda do pH nos reatores IFAS 2 e IFAS 3 para em torno de 4,0, obrigando a dar uma nova partida - ocorrida no dia 22/09/2015. Sendo que,durante esse 
período, tentou-se readequar o pH dos reatores com adição de Bicarbonato de Sódio (alcalinidade) eHidróxido de Sódio (alcalinizante), sem êxito.

Assim, será apresentado a seguir os resultados dos 3 reatores, sendo que nos IFAS 2 e IFAS 3 serãosubdivididos em antes e após a nova partida(repartida).

Alémdisso, conforme supracitado, considerou-se a remoção de matéria orgânica somente quanto a DQO solúvel, posto que a DQO total afluente foi idêntica a DQO solúvel.

\subsubsection{Análises físico-químicas}

A Tabela 5.9 apresenta, inicialmente,os resultados adquiridos na Fase 2.2 em relação as análises físico-químicas para o reator IFAS 1.

Tabela 5.9: Resultados do monitoramento do Reator IFAS 1 - Fase $2.2\left(\mathrm{mg} \mathrm{L}^{-1}\right.$ )

\begin{tabular}{|c|c|c|c|c|c|c|c|c|c|c|}
\hline \multirow{2}{*}{\multicolumn{2}{|c|}{ Parâmetro }} & \multirow{2}{*}{$\begin{array}{l}\text { № de } \\
\text { dados }\end{array}$} & \multirow{2}{*}{ Média } & \multirow{2}{*}{$\begin{array}{l}\text { Desvio } \\
\text { Padrão }\end{array}$} & \multirow{2}{*}{$\begin{array}{l}\text { Coeficiente } \\
\text { de Variação }\end{array}$} & \multicolumn{5}{|c|}{ Percentis } \\
\hline & & & & & & 10 & 25 & 50 & 75 & 90 \\
\hline \multirow{3}{*}{ DQO } & Afl & 22 & 551 & 312 & 0,57 & 299 & 311 & 421 & 772 & 824 \\
\hline & Efl & 22 & 173 & 294 & 1,70 & 34 & 58 & 102 & 142 & 170 \\
\hline & Ef (\%) & 22 & 69 & 39 & 0,56 & 52 & 69 & 79 & 88 & 93 \\
\hline \multirow{3}{*}{ DQOsol } & Afl & 20 & 201 & 200 & 0,99 & 95 & 123 & 158 & 184 & 268 \\
\hline & Efl & 20 & 95 & 173 & 1,82 & 22 & 29 & 52 & 90 & 107 \\
\hline & Ef (\%) & 20 & 58 & 26 & 0,45 & 19 & 41 & 65 & 80 & 86 \\
\hline \multirow{3}{*}{ DBO } & Afl & 8 & 328 & 196 & 0,60 & 153 & 233 & 321 & 416 & 509 \\
\hline & Efl & 8 & 32 & 18 & 0,57 & 17 & 18 & 27 & 41 & 49 \\
\hline & Ef (\%) & 8 & 89 & 6 & 0,06 & 83 & 86 & 89 & 92 & 94 \\
\hline \multirow{3}{*}{ SST } & Afl & 21 & 307 & 215 & 0,70 & 82 & 134 & 272 & 424 & 555 \\
\hline & Efl & 21 & 59 & 59 & 1,00 & 14 & 31 & 42 & 56 & 126 \\
\hline & Ef (\%) & 21 & 73 & 31 & 0,42 & 50 & 62 & 81 & 92 & 95 \\
\hline \multirow{3}{*}{ NTK } & Afl & 18 & 36 & 7 & 0,18 & 28 & 31 & 36 & 39 & 45 \\
\hline & Efl & 18 & 12 & 6 & 0,53 & 6 & 7 & 11 & 15 & 18 \\
\hline & Ef (\%) & 18 & 66 & 20 & 0,31 & 47 & 54 & 73 & 79 & 86 \\
\hline \multirow{3}{*}{$\mathrm{N}-\mathrm{NH}_{4}$} & Afl & 22 & 32 & 11 & 0,33 & 21 & 26 & 29 & 41 & 46 \\
\hline & Efl & 22 & 9 & 8 & 0,93 & 0 & 1 & 8 & 13 & 21 \\
\hline & Ef (\%) & 22 & 73 & 25 & 0,35 & 42 & 56 & 78 & 97 & 99 \\
\hline \multirow{2}{*}{$\mathrm{N}-\mathrm{NO}_{2}$} & Afl & 22 & 0,30 & 0,04 & 1,30 & 0.01 & 0.01 & 0.01 & 0.03 & 0.07 \\
\hline & Efl & 22 & 0,33 & 0,21 & 0,66 & 0.09 & 0.15 & 0.31 & 0.46 & 0.61 \\
\hline \multirow{2}{*}{$\mathrm{N}-\mathrm{NO}_{3}$} & Afl & 22 & 3,0 & 3,8 & 1,26 & 0.61 & 0.85 & 1.2 & 2.83 & 9.33 \\
\hline & $\mathrm{Efl}$ & 22 & 10,2 & 6,1 & 0,59 & 1.95 & 6.90 & 9.90 & 15.48 & 18.15 \\
\hline
\end{tabular}

Pode-se verificar que no reator IFAS 1 foram obtidaseficiências médias de matéria orgânica, DQO, DQOsol e DBO,de 69\%, 58\% e 89\%, respectivamente, alcançando valores acima de $86 \%$ (percentil 25) para DBO, com concentração média efluente de $32 \mathrm{mg} \mathrm{L}^{-1}$. 
Quando se observa a eficiência de remoção de SST, verifica-se que foi da ordem de $73 \%$, obtendo concentração média efluente de $59 \mathrm{mg} \mathrm{L}^{-1}$.

Em relação a remoção de compostos nitrogenados, nota-se que o reator IFAS 1 alcançou eficiências médias de NTK e N-NH 4 igual a $66 \%$ e $73 \%$, correspondente a concentrações médias efluente de $12 \mathrm{mg} \mathrm{L}^{-1}$ e $9 \mathrm{mg} \mathrm{L}^{-1}$, respectivamente. Isto com uma produção de $\mathrm{N}$ $\mathrm{NO}_{3}$ de cerca de $300 \%$, equivalente a concentração efluente de $10,2 \mathrm{mg} \mathrm{L}^{-1}$ e, de $\mathrm{N}-\mathrm{NO}_{2}$, praticamente manteve constante, em torno de $0,3 \mathrm{mg} \mathrm{L}^{-1}$.

Esses resultados podem também teremsido influenciados pelos diversos choques de salinidades ocorridos durante essa fase, tais como: dia 36: $2.581 \mathrm{mg} \mathrm{Cl}^{-1}$; dia 37: 2.578 $\mathrm{mg} \mathrm{Cl}^{-1}$; dia 65: $2.410 \mathrm{mg} \mathrm{Cl}^{-1}$; dia 70: $1.852 \mathrm{mg} \mathrm{Cl}^{-1}$; dia 77: $5.648 \mathrm{mg} \mathrm{Cl}^{-1}$; dia 78: $3.099 \mathrm{mg} \mathrm{Cl}^{-1}$; confome ilustram os gráficos das Figuras 5.28 e 5.29, considerando o comportamento da DQO e N-NH .

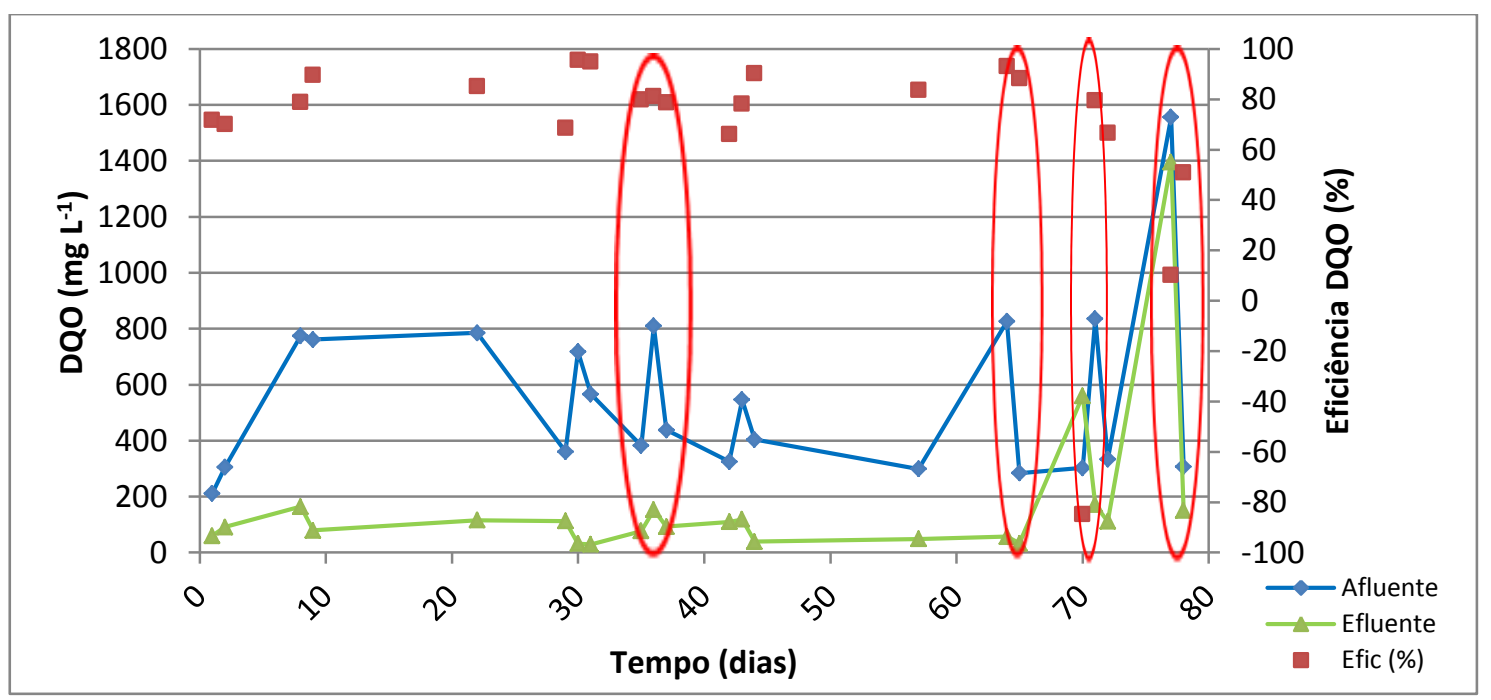

Figura 5.28: DQO afluente e efluente e eficiência DQO - IFAS 1 


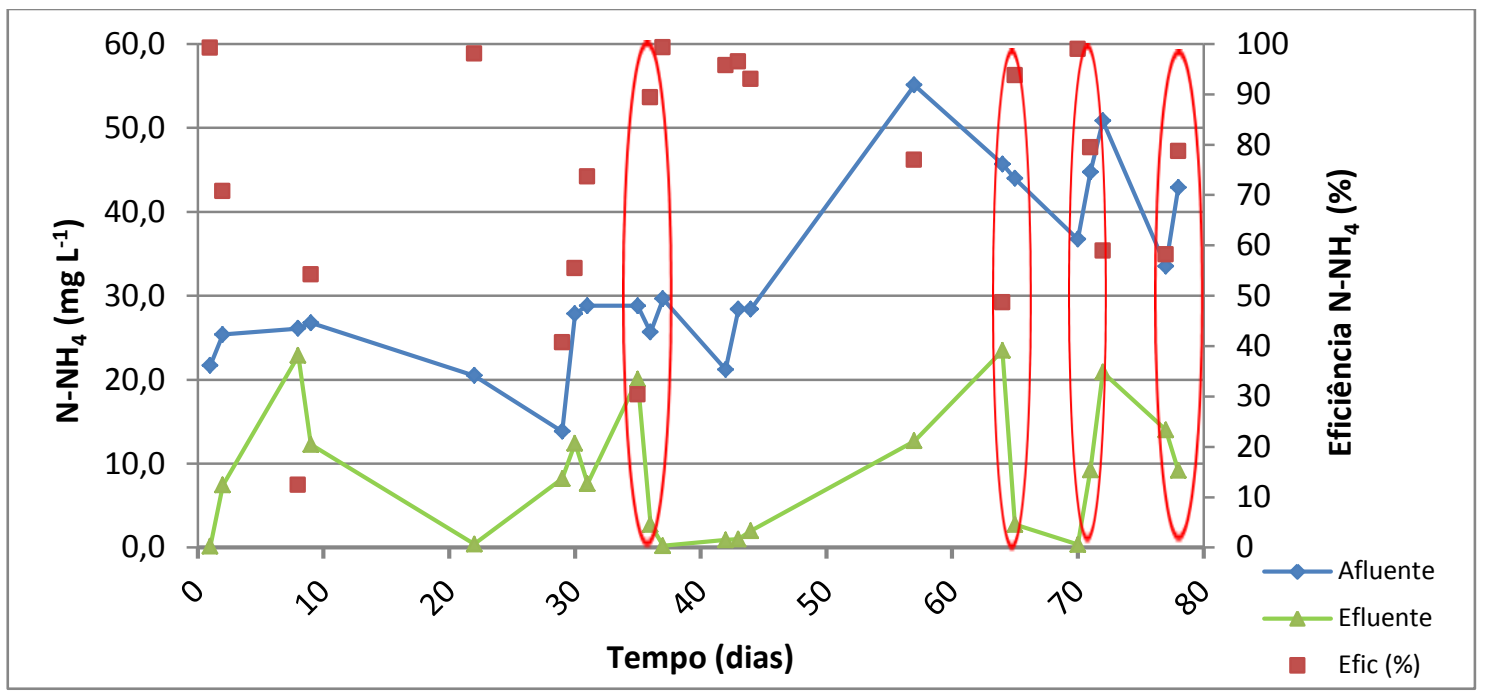

Figura 5.29: $\mathrm{N}-\mathrm{NH}_{4}$ afluente e efluente e eficiência $\mathrm{N}-\mathrm{NH}_{4}-$ IFAS 1

Ainda assim, como pode-se perceber por meio dos gráficos das Figuras 5.30 e 5.31, quanto maior foi a COS aplicada maior foi a eficiência DQO ou menor a eficiência de N$\mathrm{NH}_{4}$, conforme esperado.

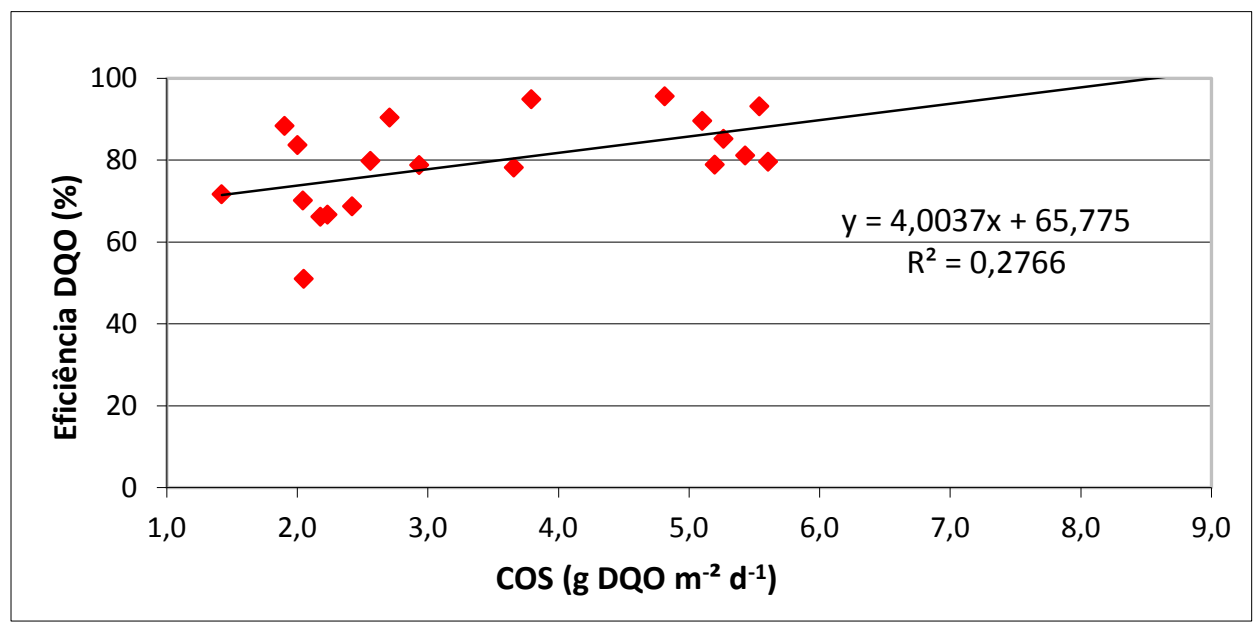

Figura 5.30: Eficiência de remoção de DQOversus COS aplicada - IFAS 1

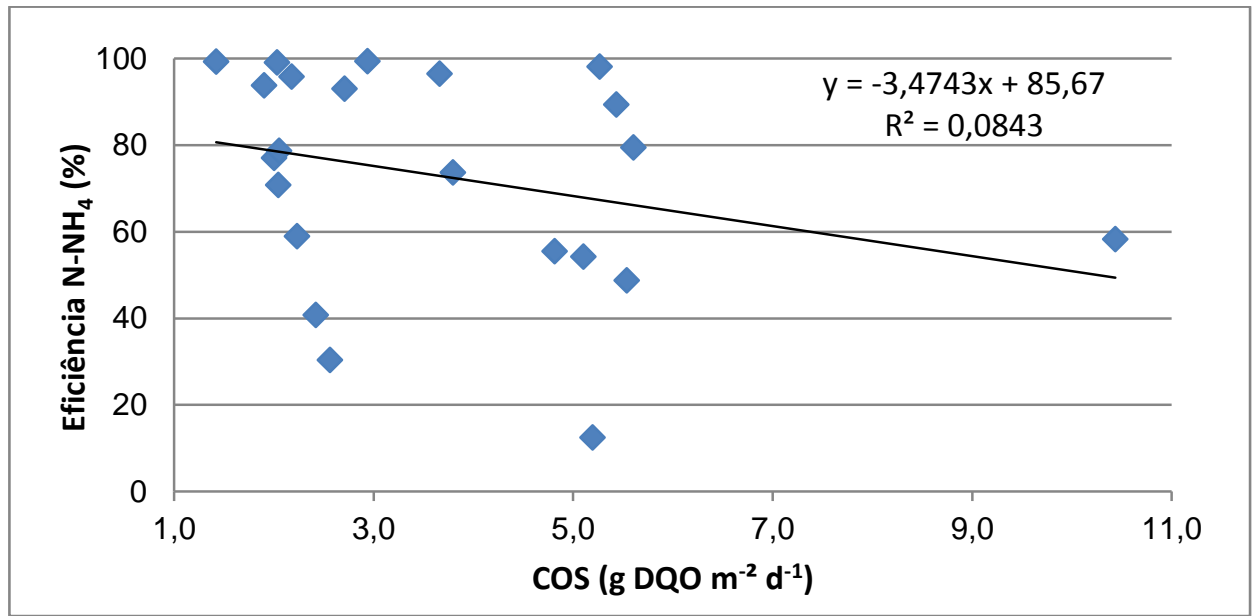


Figura 5.31: Eficiência de remoção de $\mathrm{N}-\mathrm{NH}_{4}$ versus COS aplicada - IFAS 1

Apresentam-se nas Tabelas 5.10 e 5.11,os resultados das análises físico-químicas obtidos na Fase 2.2 para os reatores IFAS 2 e IFAS 3 (antes da repartida). Pode-se reparar que, as eficiências médias de DQOsol foram da ordem de 92\%, obtendo concentração média efluente de, aproximadamente, $47 \mathrm{mg} \mathrm{L}^{-1}$ para ambos reatores.Observa-se que $50 \%$ do resultados de eficiência remoçãode DBO, alcançaram valores superiores a $91 \%$ para o reator IFAS 2; já no reator IFAS 3 alcançou eficiência média de DBO de cerca de $74 \%$ (concentração média efluente $137 \mathrm{mg} \mathrm{L}^{-1}$ ). De qualquer forma, esses resultados de DBO não podem ser atribuídos a concentração efluente de SST. Visto que, concentração média efluente de SST no reator IFAS 2 foi superior a do reator IFAS 3, equivalente a $196 \mathrm{mg} \mathrm{L}^{-1} \mathrm{e}$ $151 \mathrm{mg} \mathrm{L}^{-1}$, respectivamente.

Tabela 5.10: Resultados do monitoramento do Reator IFAS 2 - Fase 2.2 (mg L ${ }^{-1}$ ) (antes da repartida)

\begin{tabular}{|c|c|c|c|c|c|c|c|c|c|c|}
\hline \multirow{2}{*}{\multicolumn{2}{|c|}{ Parâmetro }} & \multirow{2}{*}{$\begin{array}{l}\text { № de } \\
\text { dados }\end{array}$} & \multirow{2}{*}{ Média } & \multirow{2}{*}{$\begin{array}{l}\text { Desvio } \\
\text { Padrão }\end{array}$} & \multirow{2}{*}{$\begin{array}{l}\text { Coeficiente } \\
\text { de Variação }\end{array}$} & \multicolumn{5}{|c|}{ Percentis } \\
\hline & & & & & & 10 & 25 & 50 & 75 & 90 \\
\hline \multirow{3}{*}{ DQOsol } & Afl & 14 & 613 & 71 & 0,12 & 530 & 565 & 614 & 673 & 689 \\
\hline & Efl & 14 & 49 & 49 & 0,99 & 13 & 21 & 32 & 46 & 135 \\
\hline & Ef (\%) & 14 & 92 & 8 & 0,08 & 79 & 92 & 95 & 96 & 98 \\
\hline \multirow{3}{*}{ DBO } & Afl & 4 & 567 & 104 & 0,18 & 481 & 526 & 600 & 625 & 641 \\
\hline & Efl & 4 & 47 & 18 & 0,39 & 32 & 41 & 57 & 58 & 59 \\
\hline & Ef (\%) & 4 & 91 & 4 & 0,05 & 88 & 89 & 91 & 93 & 95 \\
\hline SST & $\mathrm{Efl}$ & 14 & 196 & 107 & 0,55 & 86 & 136 & 180 & 250 & 287 \\
\hline \multirow{3}{*}{ NTK } & Afl & 12 & 38 & 8 & 0,20 & 32 & 32 & 34 & 42 & 49 \\
\hline & Efl & 12 & 23 & 13 & 0,54 & 10 & 15 & 17 & 29 & 38 \\
\hline & Ef (\%) & 12 & 41 & 21 & 0,51 & 17 & 24 & 48 & 52 & 67 \\
\hline \multirow{3}{*}{$\mathrm{N}-\mathrm{NH}_{4}$} & Afl & 13 & 35 & 6 & 0,18 & 30 & 31 & 32 & 36 & 45 \\
\hline & Efl & 13 & 19 & 7 & 0,37 & 14 & 15 & 17 & 18 & 30 \\
\hline & Ef (\%) & 13 & 46 & 9 & 0,20 & 34 & 45 & 46 & 52 & 54 \\
\hline \multirow{2}{*}{$\mathrm{N}-\mathrm{NO}_{2}$} & Afl & 14 & 0,01 & 0,01 & 0,98 & 0,01 & 0,01 & 0,01 & 0,01 & 0,01 \\
\hline & Efl & 14 & 0,21 & 0,62 & 2,93 & 0,01 & 0,01 & 0,01 & 0,05 & 0,24 \\
\hline \multirow{2}{*}{$\mathrm{N}-\mathrm{NO}_{3}$} & Afl & 14 & 2,21 & 1,11 & 0,50 & 1.20 & 1.35 & 1.90 & 2.85 & 3.30 \\
\hline & Efl & 14 & 1,97 & 1,54 & 0,78 & 0.96 & 1.20 & 1.45 & 1.98 & 3.18 \\
\hline
\end{tabular}

Tabela 5.11: Resultados do monitoramento do Reator IFAS 3 - Fase $2.2\left(\mathrm{mg} \mathrm{L}^{-1}\right.$ ) (antes da nova partida)

\begin{tabular}{|c|c|c|c|c|c|c|c|c|c|c|}
\hline \multirow{2}{*}{\multicolumn{2}{|c|}{ Parâmetro }} & \multirow{2}{*}{$\begin{array}{l}\text { № de } \\
\text { dados }\end{array}$} & \multirow{2}{*}{ Média } & \multirow{2}{*}{$\begin{array}{l}\text { Desvio } \\
\text { Padrão }\end{array}$} & \multirow{2}{*}{$\begin{array}{l}\text { Coeficiente } \\
\text { de Variação }\end{array}$} & \multicolumn{5}{|c|}{ Percentis } \\
\hline & & & & & & 10 & 25 & 50 & 75 & 90 \\
\hline \multirow{3}{*}{ DQOsol } & Afl & 14 & 613 & 71 & 0,12 & 530 & 565 & 614 & 673 & 689 \\
\hline & Efl & 14 & 43 & 24 & 0,56 & 20 & 23 & 32 & 56 & 79 \\
\hline & Ef (\%) & 14 & 93 & 4 & 0,05 & 88 & 91 & 94 & 96 & 97 \\
\hline \multirow{2}{*}{ DBO } & Afl & 4 & 567 & 104 & 0,18 & 481 & 526 & 600 & 625 & 641 \\
\hline & Efl & 4 & 137 & 46 & 0,34 & 110 & 111 & 111 & 151 & 175 \\
\hline
\end{tabular}




\begin{tabular}{|c|c|c|c|c|c|c|c|c|c|c|}
\hline & Ef (\%) & 4 & 74 & 14 & 0,19 & 63 & 70 & 82 & 82 & 83 \\
\hline SST & Efl & 14 & 151 & 40 & 0,26 & 110 & 126 & 144 & 162 & 203 \\
\hline \multirow{3}{*}{ NTK } & Afl & 12 & 38 & 8 & 0,20 & 32 & 32 & 34 & 42 & 49 \\
\hline & Efl & 12 & 24 & 12 & 0,49 & 11 & 18 & 21 & 34 & 40 \\
\hline & Ef (\%) & 12 & 39 & 19 & 0,48 & 18 & 20 & 38 & 49 & 66 \\
\hline \multirow{3}{*}{$\mathrm{N}-\mathrm{NH}_{4}$} & Afl & 13 & 35 & 6 & 0,18 & 30 & 31 & 32 & 36 & 45 \\
\hline & Efl & 13 & 21 & 7 & 0,35 & 15 & 17 & 18 & 21 & 30 \\
\hline & Ef (\%) & 13 & 42 & 11 & 0,25 & 31 & 34 & 44 & 49 & 52 \\
\hline \multirow{2}{*}{$\mathrm{N}-\mathrm{NO}_{2}$} & Afl & 14 & 0,01 & 0,01 & 0,98 & 0.01 & 0.01 & 0.01 & 0.01 & 0.01 \\
\hline & Efl & 14 & 0,09 & 0,23 & 2,62 & 0.01 & 0.01 & 0.01 & 0.01 & 0.17 \\
\hline \multirow{2}{*}{$\mathrm{N}-\mathrm{NO}_{3}$} & Afl & 14 & 2,75 & 2,39 & 0,87 & 1.20 & 1.35 & 1.90 & 2.85 & 4.60 \\
\hline & Efl & 14 & 4,83 & 7,61 & 1,58 & 1.00 & 1.10 & 1.20 & 2.53 & 16.86 \\
\hline
\end{tabular}

Quando se avalia a remoção de nitrogênio, constata-se que praticamente nãoocorreu nitrificação, pois as eficiências médias de remoção de NTK e N-NH${ }_{4}$ foram em torno de apenas $40 \%$ para os dois reatores, e a geração de $\mathrm{N}-\mathrm{NO}_{2} \mathrm{e} \mathrm{N}-\mathrm{NO}_{3}$ foi quase nula.

Essa limitada remoção nitrogênio se deve,sobretudo, pela acidificação dos reatores (pH igual a 4,0). Ou seja, pelo desequilíbrio e queda do pH aferido no dia 29/08/2015, perdurando até dia 21/09/2015.

Nesse sentido, os gráficos das Figuras 5.32 e 5.33 ilustram o comportamento do nitrogênio amoniacal ao logo desse período, apontandoa data do evento de acidificação (dia 29).

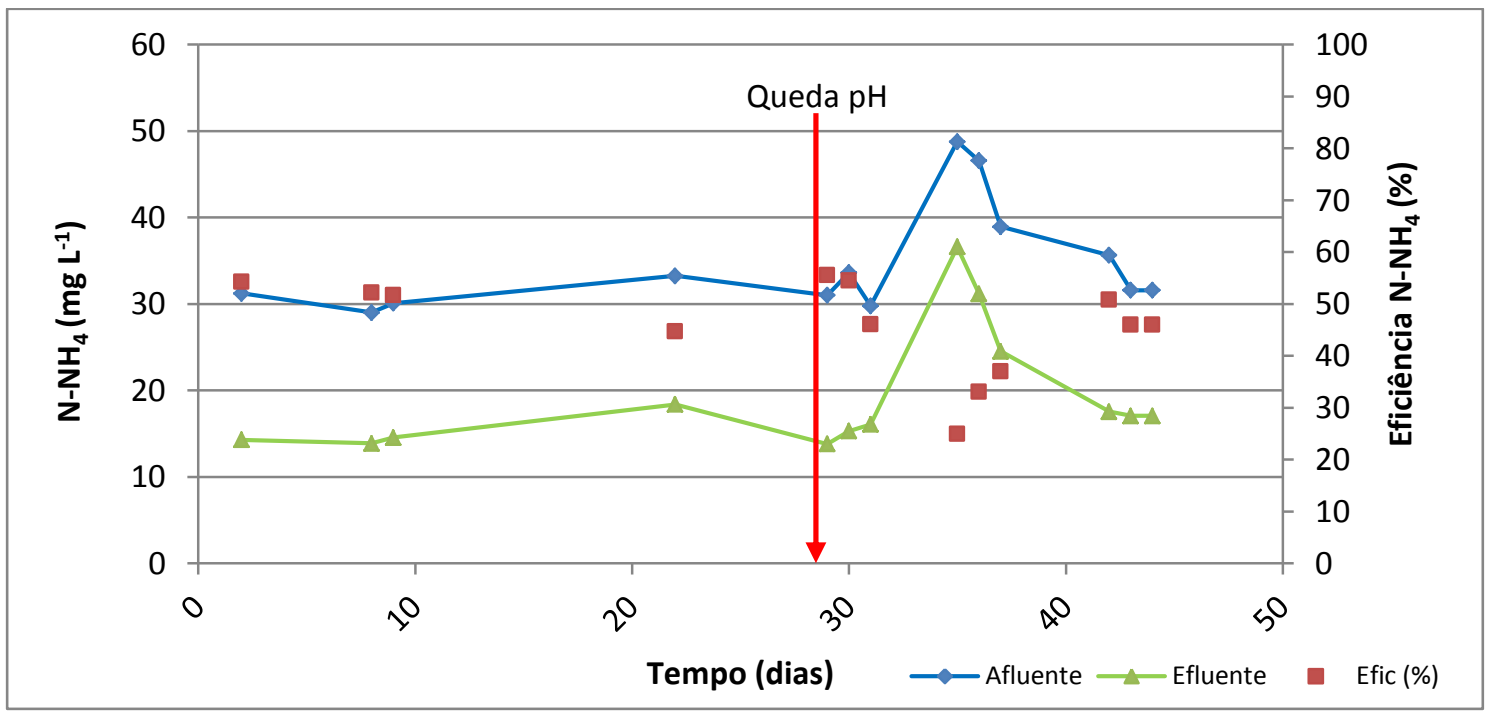

Figura 5.32: $\mathrm{N}-\mathrm{NH}_{4}$ afluente e efluente e eficiência $\mathrm{N}-\mathrm{NH}_{4}-$ IFAS 2 (antes da repartida) 


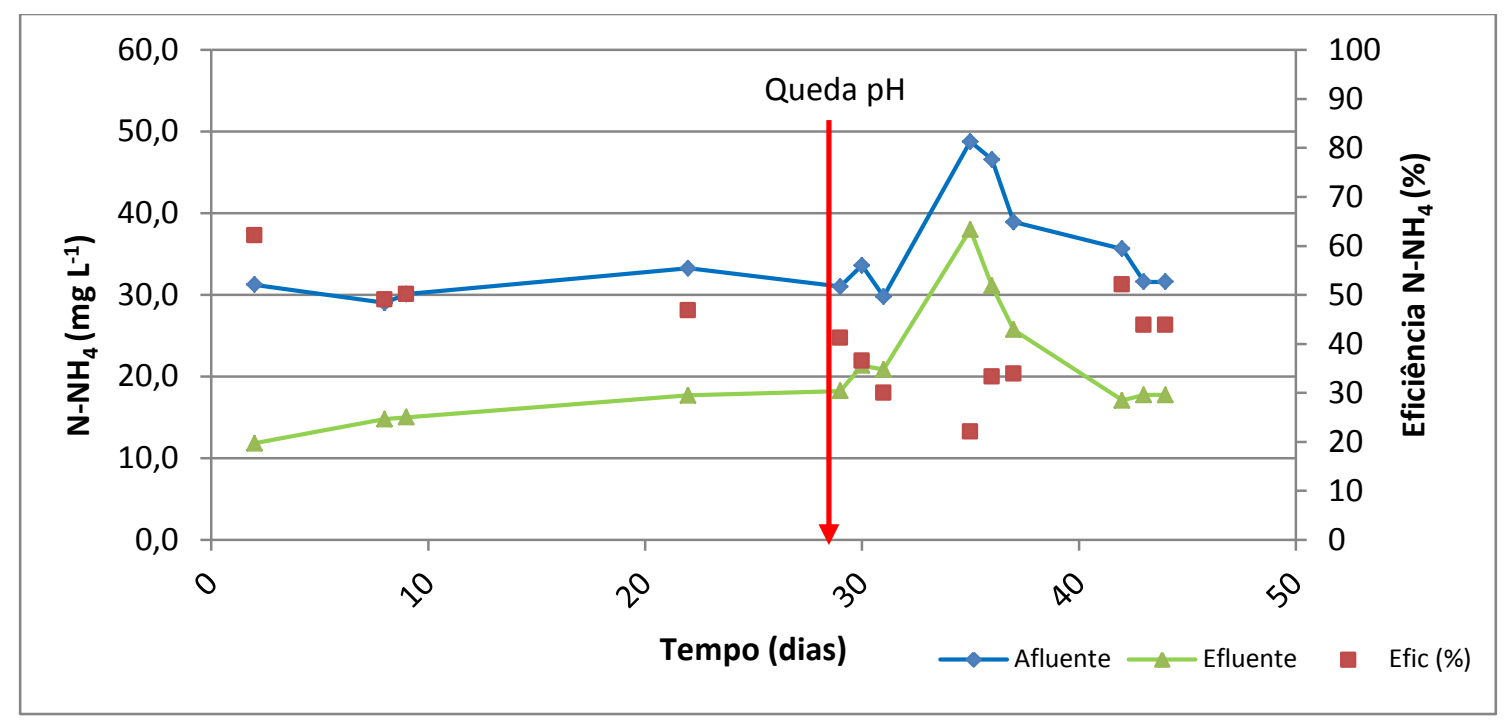

Figura 5.33: $\mathrm{N}-\mathrm{NH}_{4}$ afluente e efluente e eficiência $\mathrm{N}-\mathrm{NH}_{4}-$ IFAS 3(antes da repartida)

Porém, quando se relaciona a acidificação dos reatores com o desempenho da DQOsol, conforme ilustram os gráficos das Figuras 5.34 e 5.35, repara-se que não houve tanta interferência. Isto corrobora com a literatura quando preconiza que os microrganismos autotróficos nitrificantes trabalham em pH ligeiramente alcalino, entre 7,2 e 9,0, e que os heterotróficos suportam maior variação de $\mathrm{pH}$, desde 4,0 até 9,0 (ABREU, 1994; VON SPERLING, 1997; METCALF \& EDDY, 2003; FERREIRA, 2002; JORDÃO \& PESSÔA, 2014).

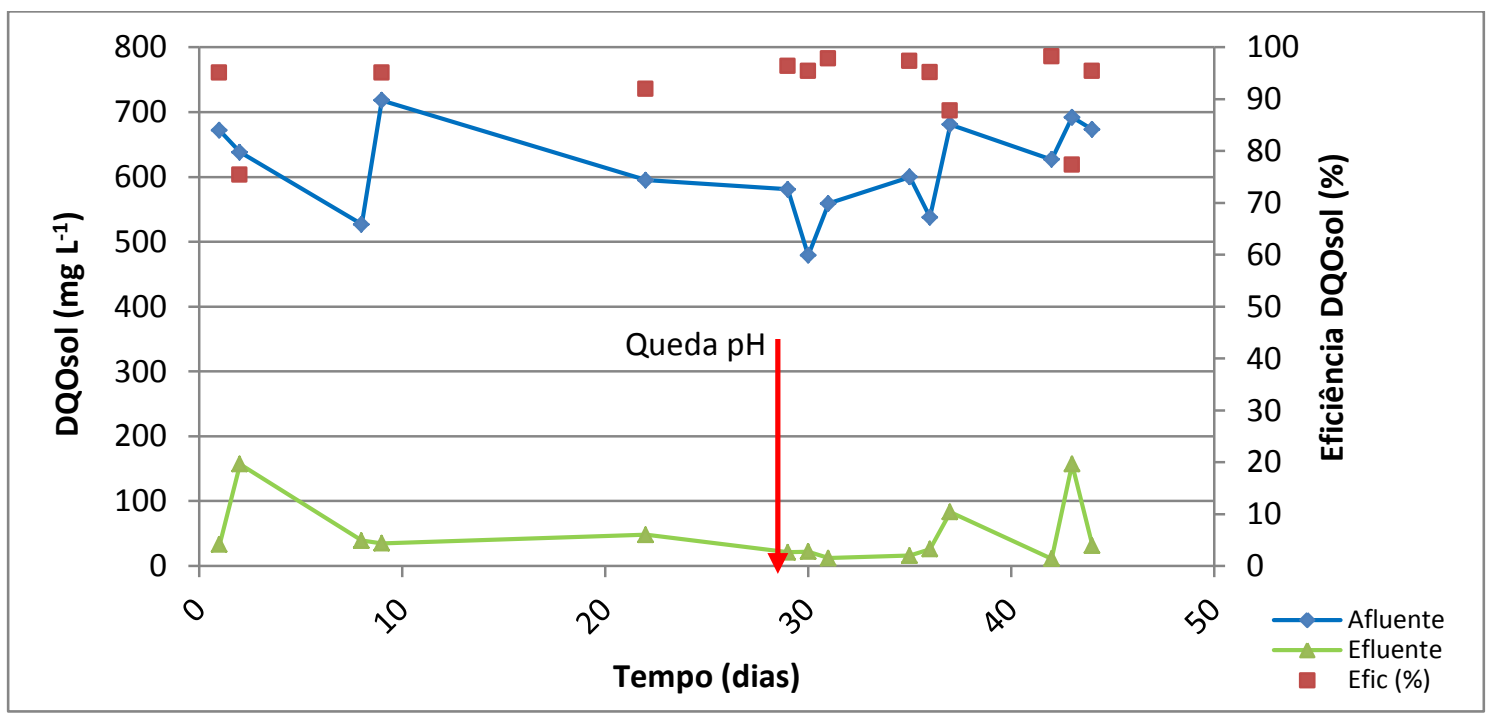

Figura 5.34: $\mathrm{DQO}_{\text {sol }}$ afluente e efluente e eficiência $\mathrm{DQO}_{\text {sol }}$ - IFAS 2(antes da repartida) 


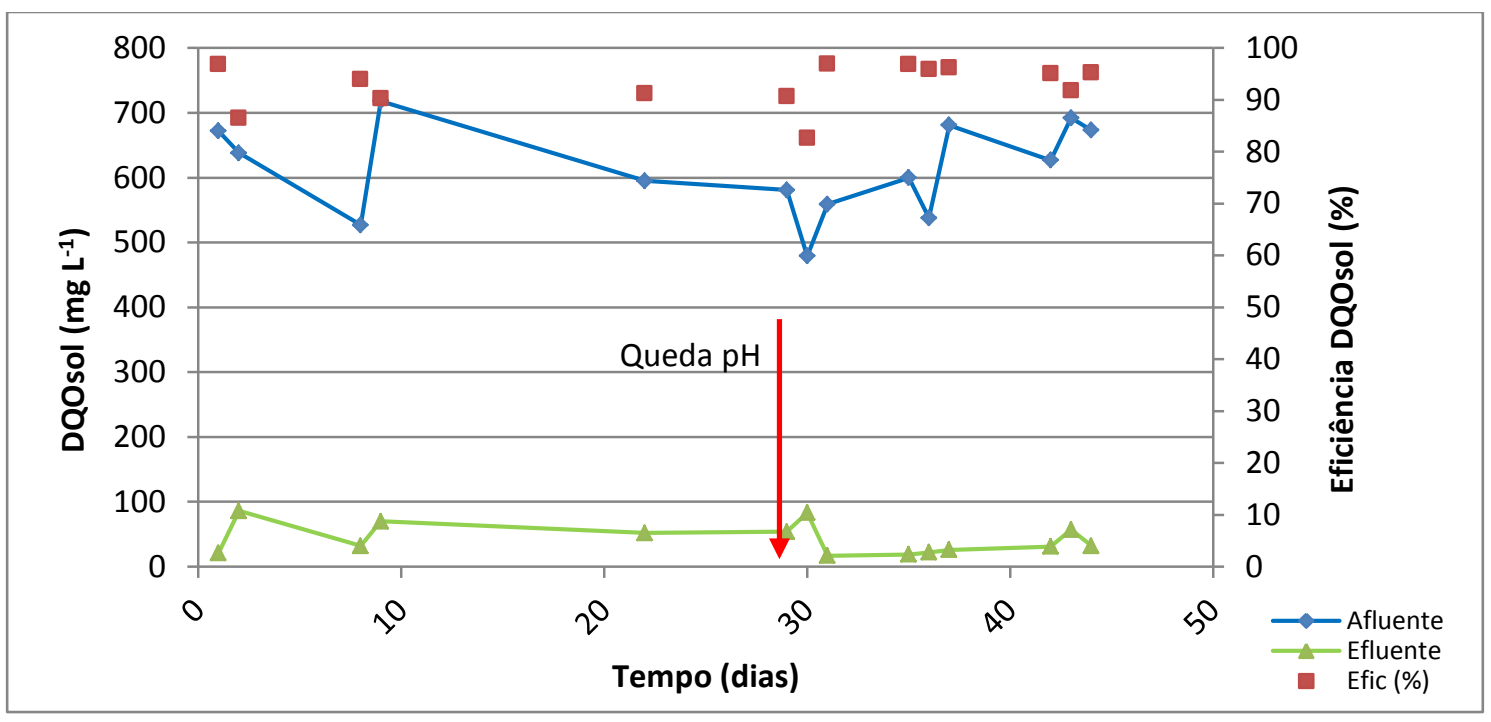

Figura 5.35: $\mathrm{DQO}_{\text {sol }}$ afluente e efluente e eficiência $\mathrm{DQO}_{\text {sol }}$ - IFAS 3(antes da repartida)

Já as Tabelas 5.12 e 5.13a seguir expõem os resultados das análises físico-químicas obtidos após a repartida dos reatores IFAS 2 e IFAS 3.

Tabela 5.12: Resultados do monitoramento do Reator IFAS 2 - Fase 2.2 (mg L ${ }^{-1}$ ) (após a repartida)

\begin{tabular}{|c|c|c|c|c|c|c|c|c|c|c|}
\hline \multirow{2}{*}{\multicolumn{2}{|c|}{ Parâmetro }} & \multirow{2}{*}{$\begin{array}{l}\text { № de } \\
\text { dados }\end{array}$} & \multirow{2}{*}{ Média } & \multirow{2}{*}{$\begin{array}{l}\text { Desvio } \\
\text { Padrão }\end{array}$} & \multirow{2}{*}{$\begin{array}{l}\text { Coeficiente } \\
\text { de Variação }\end{array}$} & \multicolumn{5}{|c|}{ Percentis } \\
\hline & & & & & & 10 & 25 & 50 & 75 & 90 \\
\hline \multirow{3}{*}{ DQOsol } & Afl & 21 & 639 & 72 & 0,11 & 576 & 588 & 615 & 687 & 734 \\
\hline & Efl & 21 & 55 & 24 & 0,43 & 25 & 36 & 52 & 74 & 87 \\
\hline & Ef (\%) & 21 & 91 & 3,9 & 0,04 & 87 & 89 & 92 & 94 & 96 \\
\hline SST & $\mathrm{Efl}$ & 20 & 120 & 69 & 0,58 & 57 & 67 & 118 & 135 & 207 \\
\hline \multirow{3}{*}{ NTK } & Afl & 19 & 35 & 6,1 & 0,17 & 28 & 31 & 35 & 37 & 44 \\
\hline & Efl & 19 & 6,7 & 5,2 & 0,76 & 1,9 & 2,6 & 6,0 & 8,7 & 14,6 \\
\hline & Ef (\%) & 19 & 81 & 14 & 0,17 & 60 & 76 & 84 & 92 & 94 \\
\hline \multirow{3}{*}{$\mathrm{N}-\mathrm{NH}_{4}$} & Afl & 21 & 34 & 5,6 & 0,17 & 27 & 31 & 33 & 36 & 40 \\
\hline & Efl & 21 & 5,5 & 4,6 & 0,84 & 0,9 & 1,6 & 4,6 & 7,2 & 12,5 \\
\hline & Ef (\%) & 21 & 84 & 13 & 0,15 & 66 & 79 & 85 & 95 & 97 \\
\hline \multirow{2}{*}{$\mathrm{N}-\mathrm{NO}_{2}$} & Afl & 21 & 0,01 & 0,01 & 1,35 & 0,00 & 0,00 & 0,01 & 0,01 & 0,03 \\
\hline & Efl & 21 & 0,23 & 0,56 & 2,42 & 0,02 & 0,05 & 0,08 & 0,13 & 0,27 \\
\hline \multirow{2}{*}{$\mathrm{N}-\mathrm{NO}_{3}$} & Afl & 21 & 1,37 & 0,44 & 0,32 & 0,75 & 1,08 & 1,40 & 1,73 & 1,90 \\
\hline & Efl & 21 & 4,49 & 1,93 & 0,43 & 2,60 & 3,10 & 4,00 & 5,95 & 7,10 \\
\hline
\end{tabular}


Tabela 5.13: Resultados do monitoramento do Reator IFAS 3 - Fase 2.2 (mg L ${ }^{-1}$ ) (após a repartida)

\begin{tabular}{|c|c|c|c|c|c|c|c|c|c|c|}
\hline \multirow{2}{*}{\multicolumn{2}{|c|}{ Parâmetro }} & \multirow{2}{*}{$\begin{array}{l}\text { № de } \\
\text { dados }\end{array}$} & \multirow{2}{*}{ Média } & \multirow{2}{*}{$\begin{array}{l}\text { Desvio } \\
\text { Padrão }\end{array}$} & \multirow{2}{*}{$\begin{array}{l}\text { Coeficiente } \\
\text { de Variação }\end{array}$} & \multicolumn{5}{|c|}{ Percentis } \\
\hline & & & & & & 10 & 25 & 50 & 75 & 90 \\
\hline \multirow{3}{*}{ DQOsol } & Afl & 22 & 632 & 75 & 0,12 & 568 & 579 & 607 & 685 & 730 \\
\hline & Efl & 22 & 43 & 28 & 0,66 & 14 & 22 & 31 & 71 & 85 \\
\hline & $\mathrm{Ef}(\%)$ & 22 & 93 & 4 & 0,05 & 87 & 89 & 96 & 97 & 97 \\
\hline SST & Efl & 20 & 116 & 75 & 0,65 & 62 & 74 & 83 & 126 & 238 \\
\hline \multirow{3}{*}{ NTK } & Afl & 19 & 36 & 6,1 & 0,17 & 28 & 31 & 36 & 39 & 44 \\
\hline & Efl & 19 & 6,4 & 4,5 & 0,69 & 1,9 & 2,6 & 6,0 & 9,1 & 12,4 \\
\hline & Ef (\%) & 19 & 82 & & & 65 & 76 & 84 & 92 & 94 \\
\hline \multirow{3}{*}{$\mathrm{N}-\mathrm{NH}_{4}$} & Afl & 22 & 34 & 5,6 & 0,16 & 27 & 31 & 34 & 36 & 41 \\
\hline & Efl & 22 & 4,9 & 4,1 & 0,84 & 0,5 & 0,7 & 5,4 & 7,5 & 10,2 \\
\hline & Ef (\%) & 22 & 86 & 12 & 0,14 & 67 & 80 & 85 & 97 & 98 \\
\hline \multirow{2}{*}{$\mathrm{N}-\mathrm{NO}_{2}$} & Afl & 22 & 0,01 & 0,01 & 1,21 & 0,00 & 0,00 & 0,01 & 0,01 & 0,02 \\
\hline & Efl & 22 & 0,09 & 0,09 & 1,03 & 0,02 & 0,03 & 0,07 & 0,11 & 0,12 \\
\hline \multirow{2}{*}{$\mathrm{N}-\mathrm{NO}_{3}$} & Afl & 22 & 1,42 & 0,49 & 0,35 & 0,90 & 1,00 & 1,30 & 1,80 & 1,90 \\
\hline & Efl & 22 & 4,14 & 2,03 & 0,49 & 1,58 & 2,40 & 4,20 & 5,30 & 6,84 \\
\hline
\end{tabular}

Verifica-se que ambos reatores alcançaram eficiências médias de remoção de DQOsol superiores a 91\%. Destaca-se ainda que em $75 \%$ do período de monitoramentoa eficiências médias de remoção de DQOsol foram acima de 89\%.

Os gráficos das Figuras 5.36e 5.37apresentam as concentrações DQOsol afluente e efluente e as respectivas eficiências de remoção para os reatores IFAS 2 e IFAS 3.

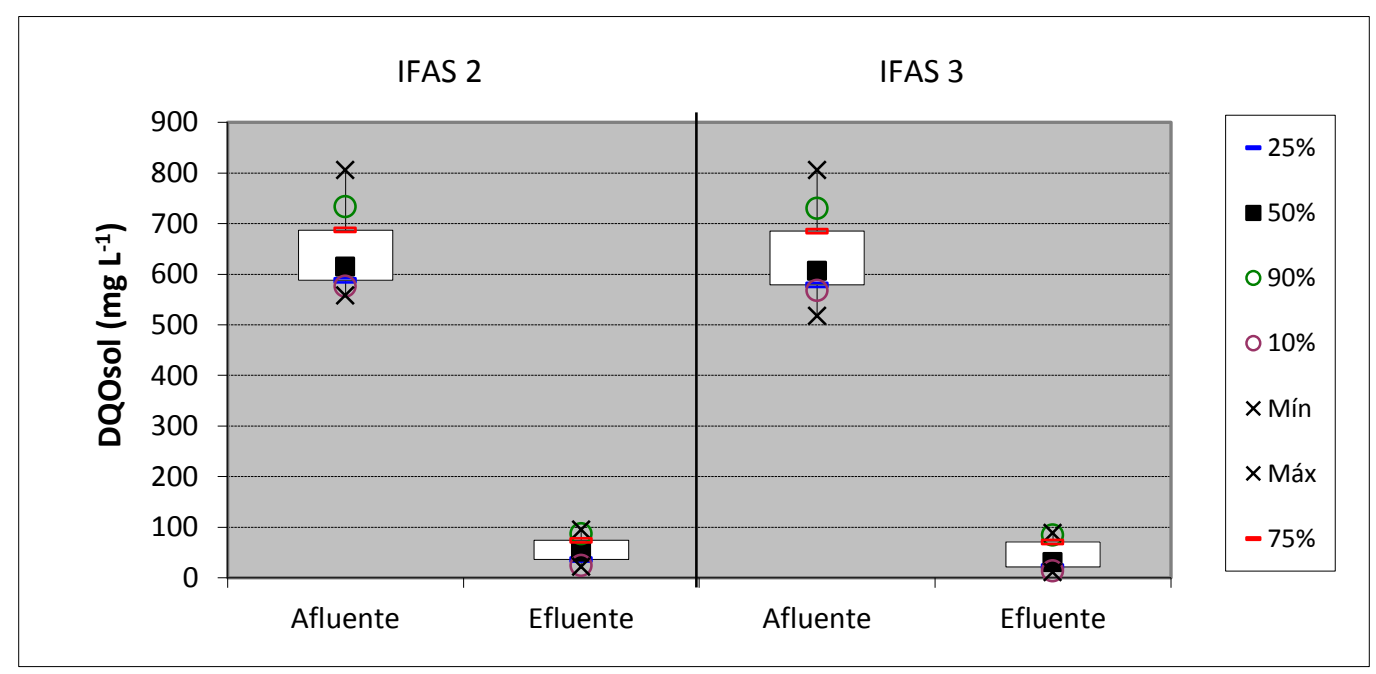

Figura 5.36: $\mathrm{DQO}_{\text {sol }}$ afluente e efluente - IFAS 2(após a repartida) 


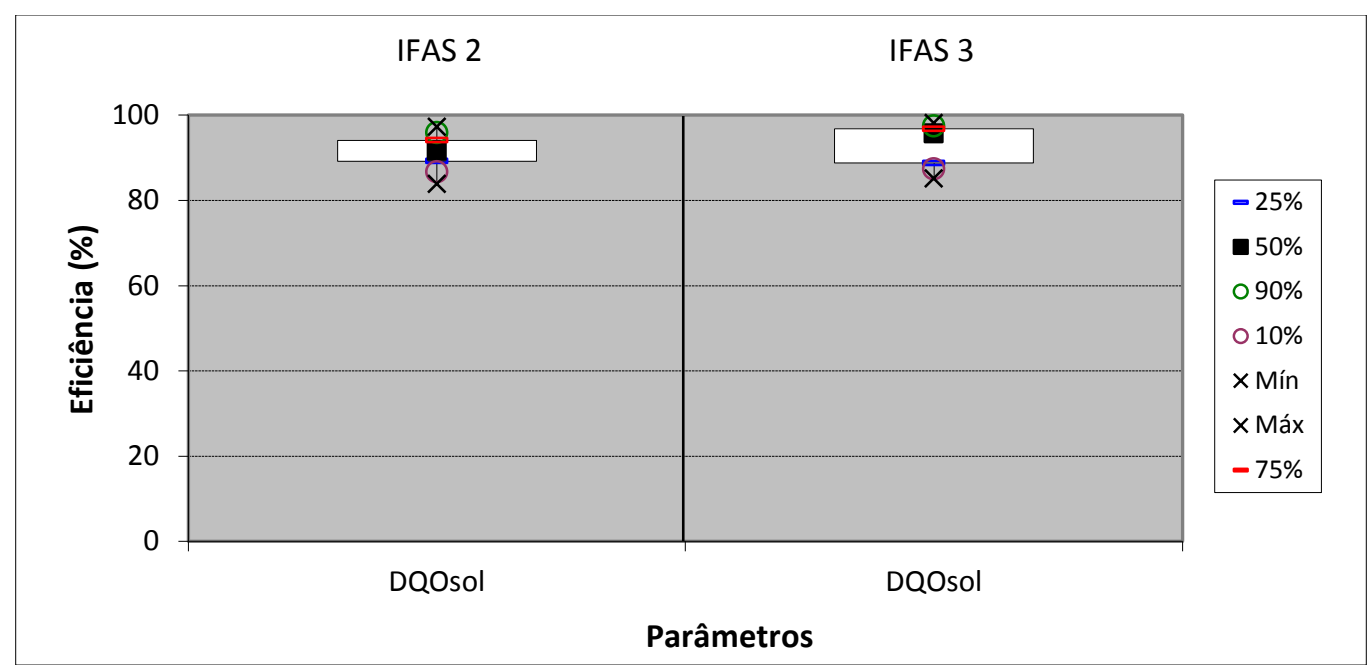

Figura 5.37: Eficiência de remoção de DQOsol - IFAS 3(após a repartida)

Conforme reportado pela literatura especializada,há uma tendência de que quanto maior foi a COS aplicada maior foi a eficiência de remoção de DQOsol para ambos reatores, como ilustram os gráficos das Figuras 5.38 a 5.39.

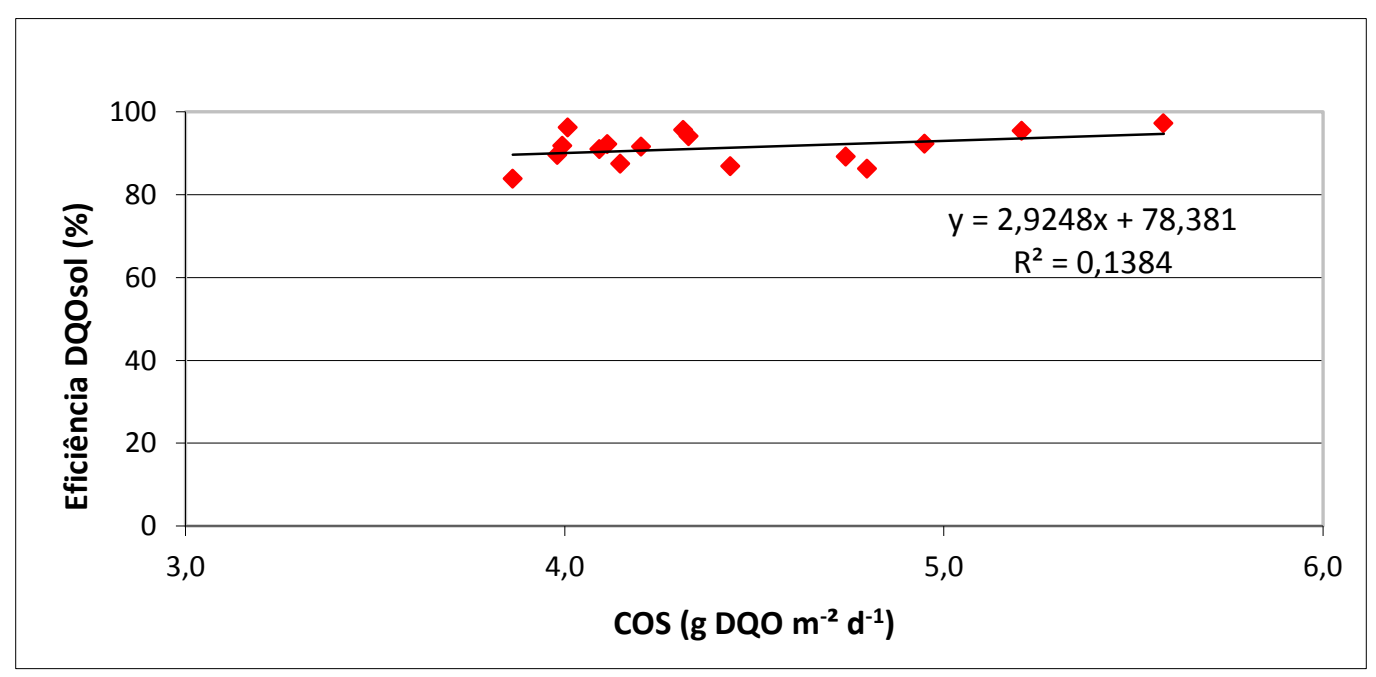

Figura 5.38: Eficiência de DQO versus COS aplicada para IFAS 2 (após a repartida) 


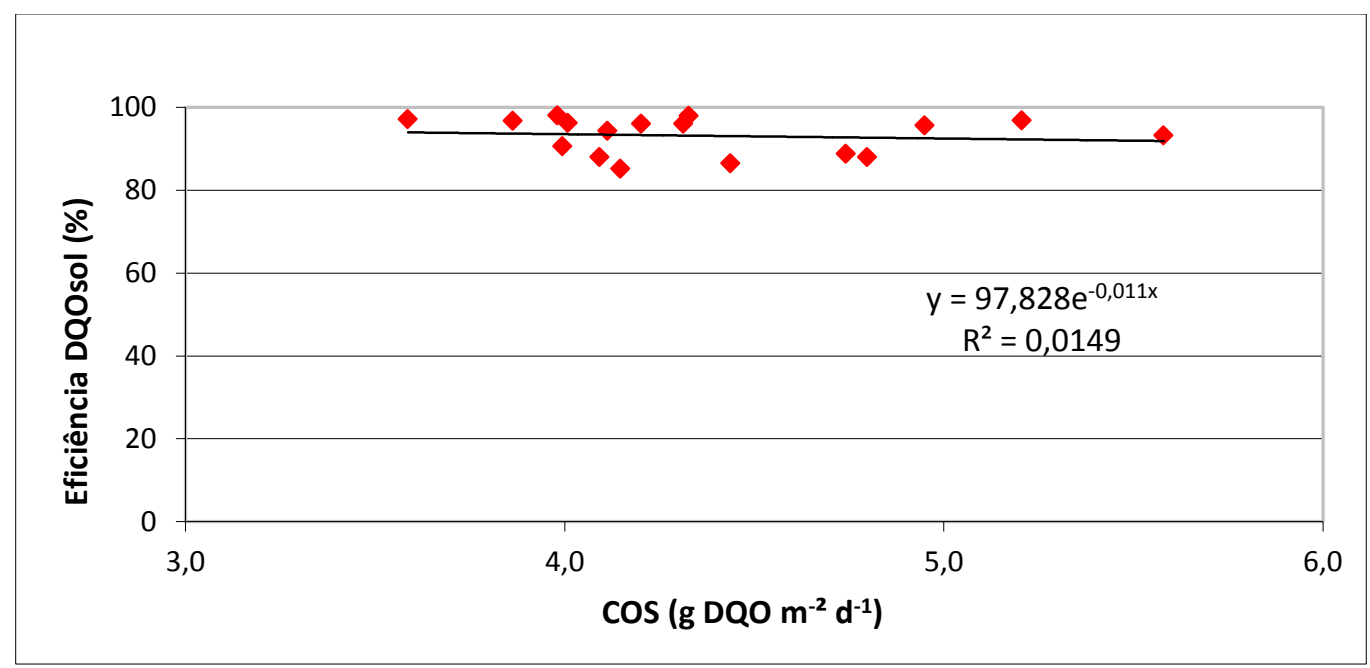

Figura 5.39: Eficiência de DQOsol versus COS aplicada para IFAS 3 (após a repartida)

Quando se avalia a eficiência de $\mathrm{N}-\mathrm{NH}_{4}$ em relação a COS aplicada, como ilustram os gráficos das Figuras 5.40 e 5.41, observa-se uma propensão de que quanto maior foi a COS aplicada menor foi a eficiência de $\mathrm{N}-\mathrm{NH}_{4}$.

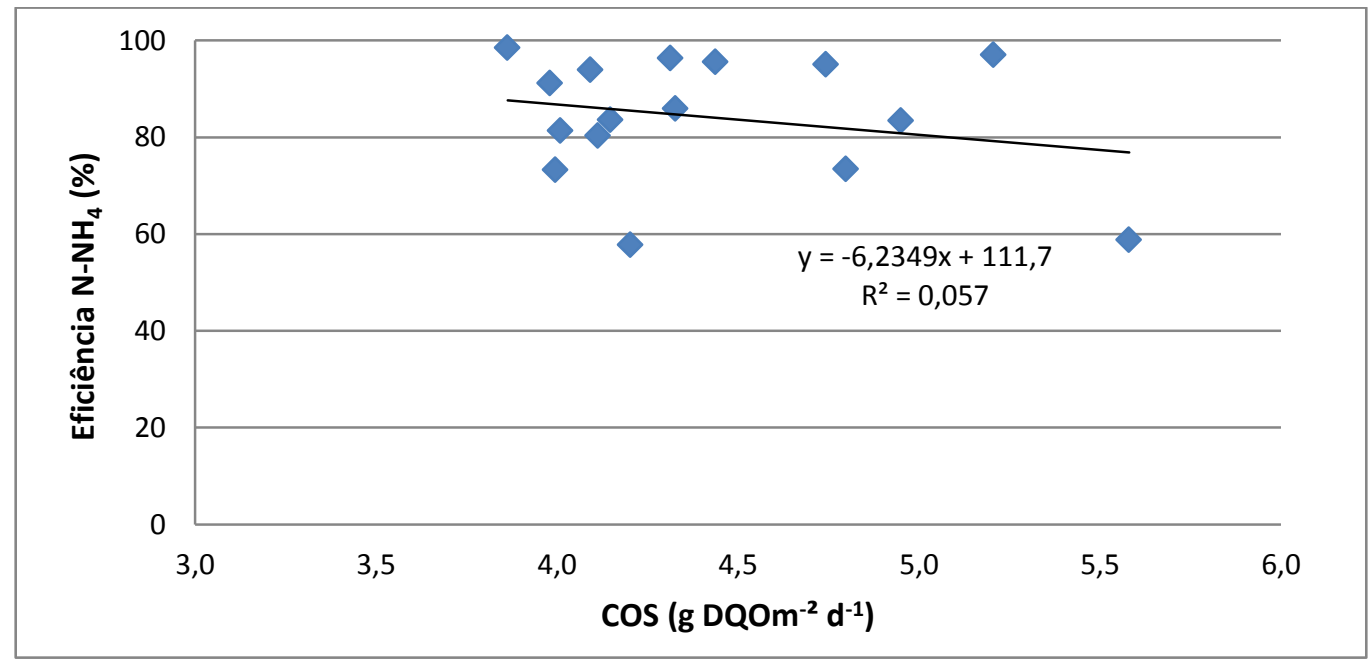

Figura 5.40: Eficiência de $\mathrm{N}-\mathrm{NH}_{4}$ versus COS aplicada para IFAS 2 (após a repartida) 


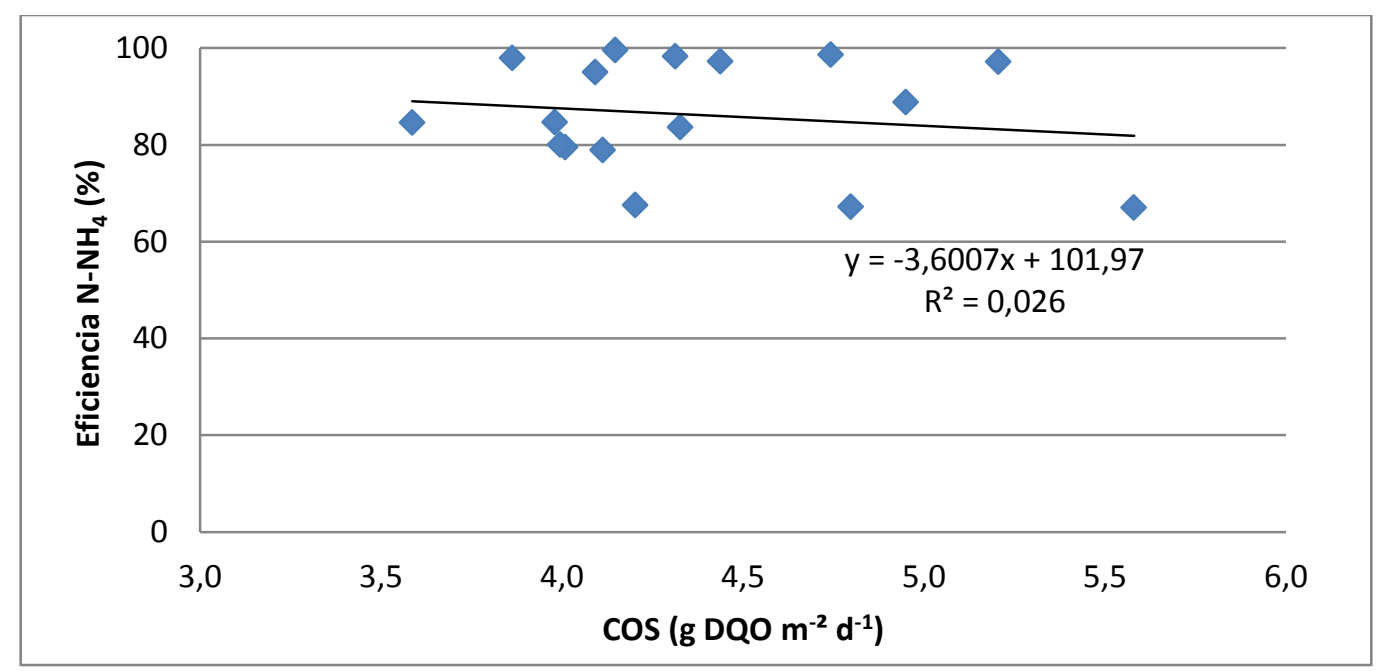

Figura 5.41: Eficiência de N-NH${ }_{4}$ versus COS aplicada para IFAS 3 (após a repartida)

Além disso, detecta-sepor meio das Tabelas 5.12 e 5.13, umaelevada eficiência médiade remoção de $\mathrm{N}-\mathrm{NH}_{4}$, da ordem de $85 \%$ (concentração médiaefluente em torno de $5,0 \mathrm{mg} \mathrm{L}$ ${ }^{1}$ ), alcançando valores superiores a $79 \%$ para os dois reatores durante $75 \%$ do período de monitoramento. Observa-setambém uma limitada produção nitrato e praticamente nenhuma alteração na concentração de nitrito.Em referência a remoção NTK, o mesmo comportamento é identificado, obtendo eficiências médias de remoção em ambos reatores de $81 \%$, equivalente a concentrações efluente inferiores a $7,0 \mathrm{mg} \mathrm{L}^{-1}$.

Os gráficos das Figuras 5.42 a 5.43apresentam esquematicamente as concentrações médias afluente e efluente dos compostos nitrogenados para os reatores IFAS 2 e IFAS 3.

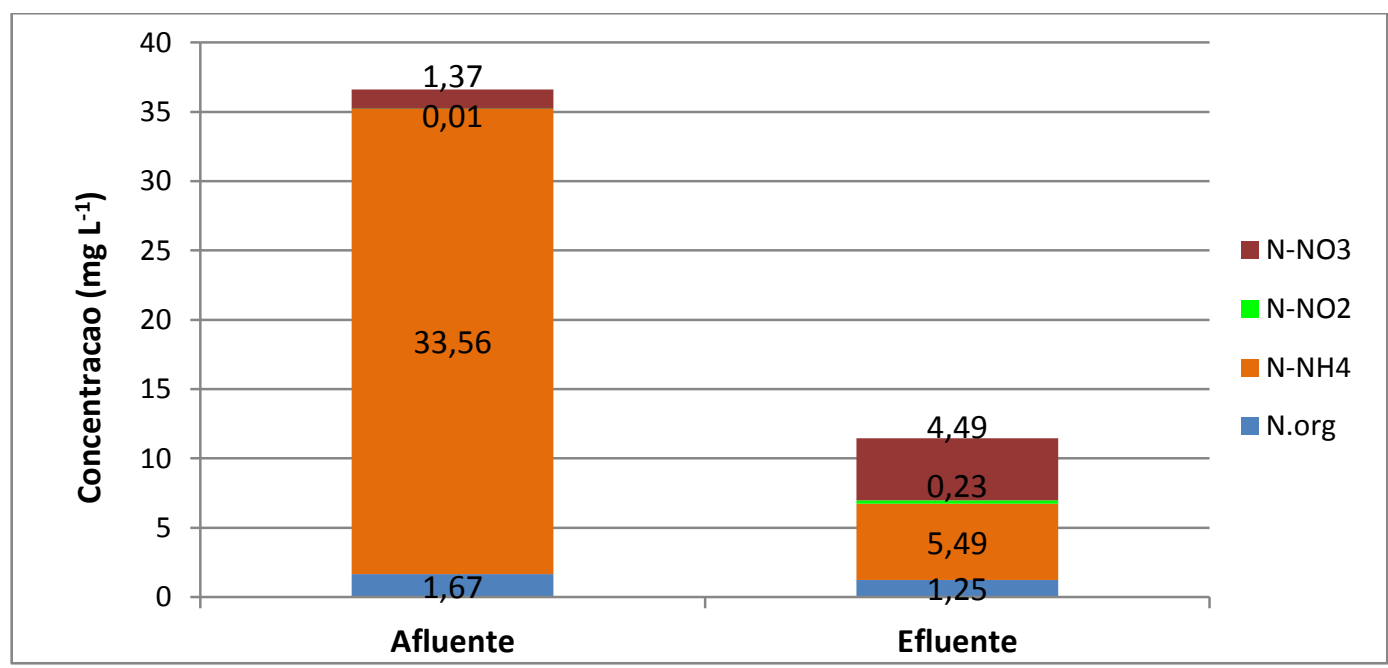

Figura 5.42:Concentração média afluente e efluente dos compostos nitrogenados IFAS 2 (após a repartida) 


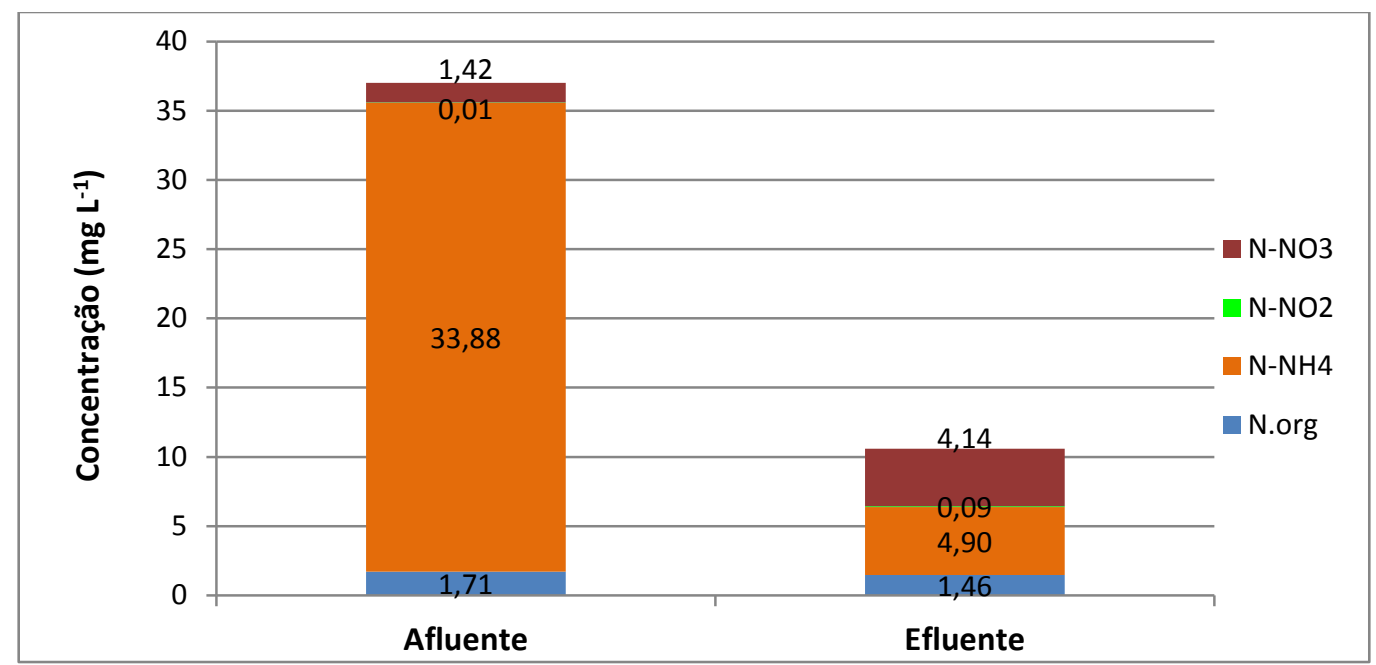

Figura 5.43:Concentração média afluente e efluente dos compostos nitrogenados IFAS

$$
\text { 3(após a repartida) }
$$

É importante destacar que, aproximadamente 10 dias após a repartida o sistema já apresentava excelentes eficiências de matéria orgânica e nitrogênio amoniacal, como demonstram os gráficos das Figuras 5.44 a 5.47. Considerando que o primeiro dia de monitoramento foi o dia 01.

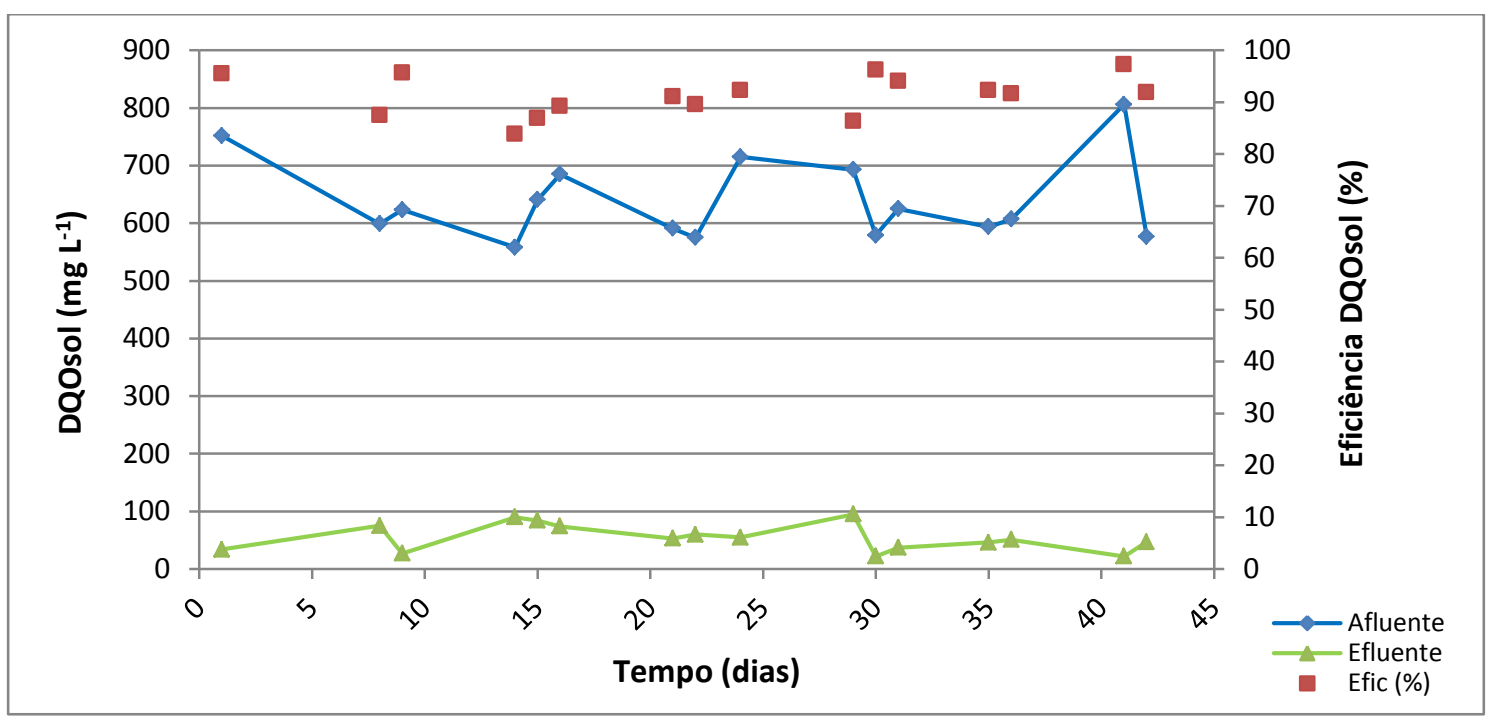

Figura 5.44: $\mathrm{DQO}_{\text {sol }}$ afluente e efluente e eficiência $\mathrm{DQO}_{\text {sol }}$ - IFAS 2(após a repartida) 


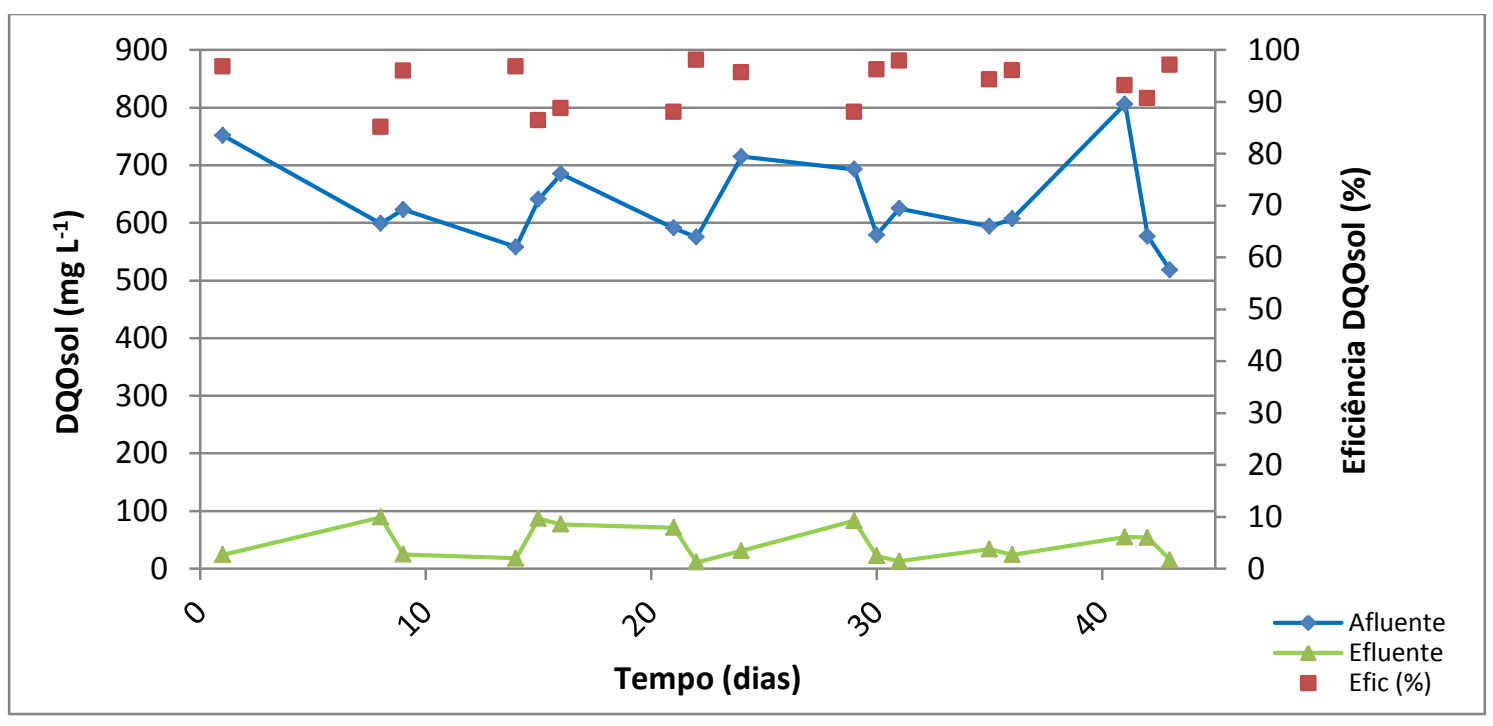

Figura 5.45: $\mathrm{DQO}_{\text {sol }}$ afluente e efluente e eficiência $\mathrm{DQO}_{\text {sol }}$ - IFAS 3 (após a repartida)

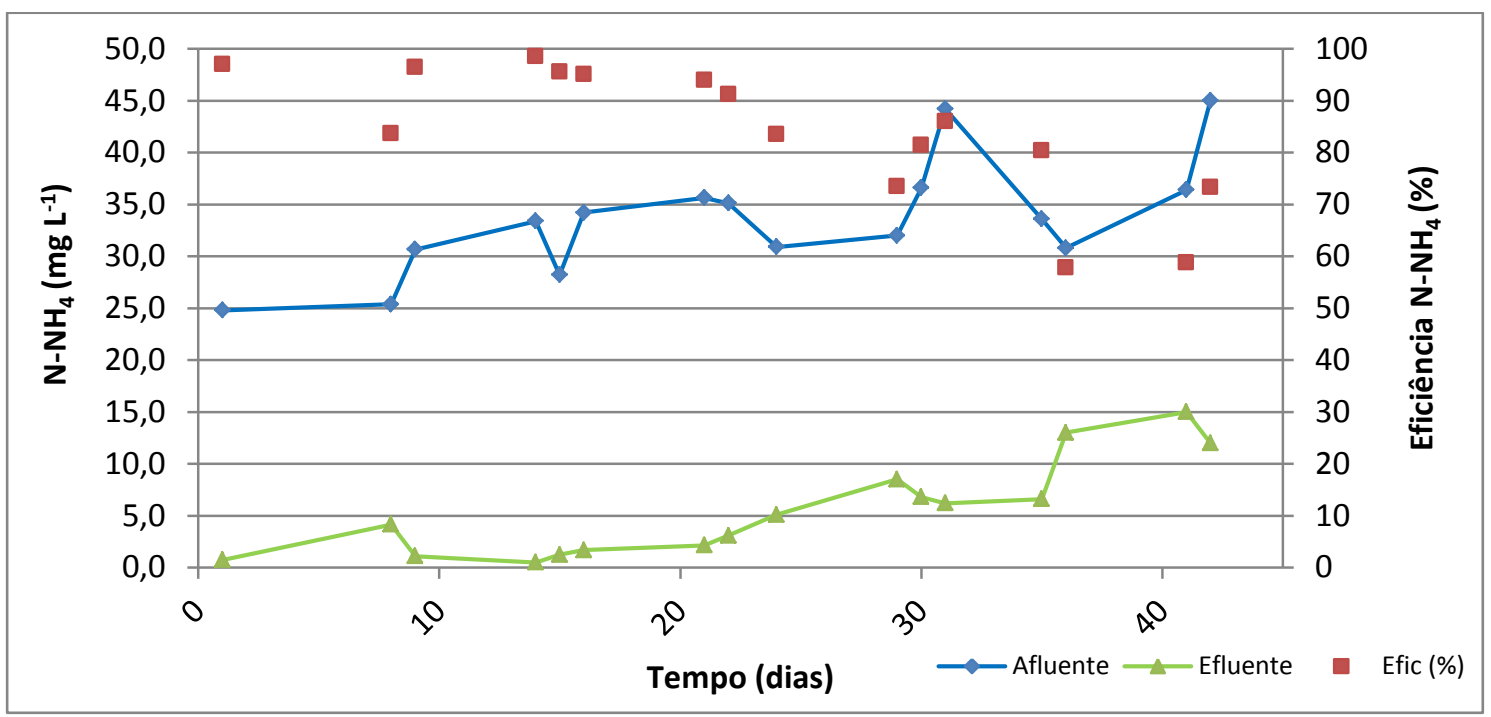

Figura 5.46: $\mathrm{N}-\mathrm{NH}_{4}$ afluente e efluente e eficiência N-NH - IFAS 2(após a repartida)

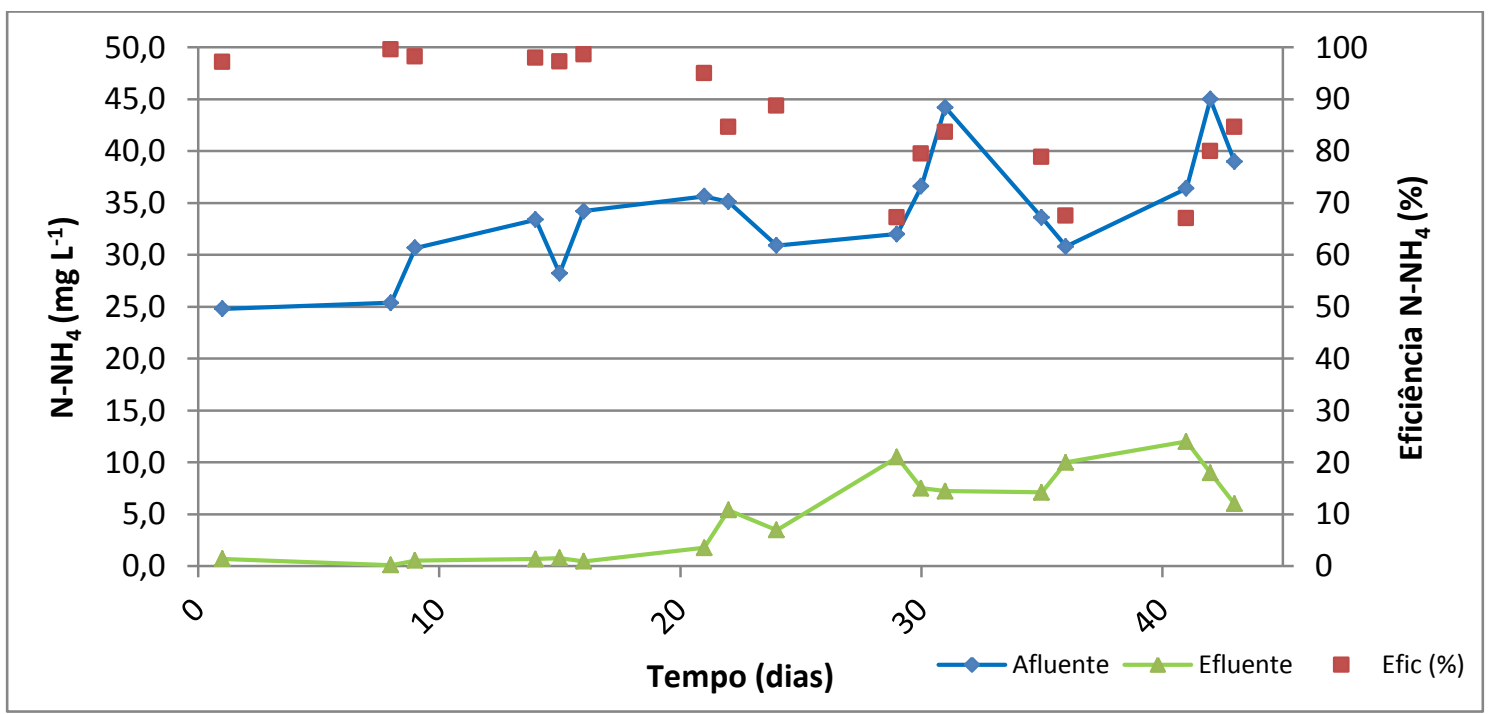

Figura 5.47: $\mathrm{N}-\mathrm{NH}_{4}$ afluente e efluente e eficiência $\mathrm{N}-\mathrm{NH}_{4}$ - IFAS 3(após a repartida) 
A respeito dessarápida capacidade de recuperação do sistema, indica-se que o procedimento adotado para a repartida foi de fundamental importância. Pois, mantevese a população microbiana aderida, auxiliando na aclimatação e estabilização do sistema como um todo.

Ademais, tal recuperação reforça a hipótese que os microrganismos de crescimento lento, autotróficos, ficampreferencialmente aderidos aos meios suporte (SRIWIRIYARAT \& RANDALL, 2005e KERMANlet. al, 2008).

Outrossim, em estudos realizados por KIM et. al 2010 e CALDERÓN et. al 2012, nos quais avaliaram microscopicamente a biomassa no processo MBBR/IFAS, indicaram que a diversidade de microrganismos aderidos aos meios suporte é muito maior do que em suspensão.

Outro ponto importante que pode ser observado,exclusivamente por meio dos gráficos das Figuras 5.46 e 5.47, é que após o dia 27 houve um ligeiro decaimento da performance do processo quanto a remoção de $\mathrm{N}_{-} \mathrm{NH}_{4}$, ocasionado por uma pequena queda do $\mathrm{pH}$. Sendo que essa queda foi causada pela adição de Acetato de Sódio ( $\mathrm{CH} 3 \mathrm{COONa}$ ) e Cloreto de Amônio $\left(\mathrm{NH}_{4} \mathrm{Cl}\right)$ utilizado durante uma tentativa de teste para avaliar os parâmetros cinéticos. Salienta-se que, esses sais, principalmente o Acetato de Sódio, possuem efeito tamponante (FIORUCCl el. al, 2001).

De qualquer modo,ainda avaliando esses gráficos, nota-se uma ascensão dos últimos resultados/dados alcançados para eficiência de remoção de $\mathrm{N}-\mathrm{NH}_{4}$, determinando queo sistema se encontrava em recuperação.

Especificamente em relação ao comportamento do $\mathrm{pH}$, pode-se observarnos gráficos das Figuras 5.48 e 5.49 a seguir que quanto menor foi o $\mathrm{pH}$ efluente (pH do reator) mais limitada foi a eficiência de remoção de $\mathrm{N}-\mathrm{NH}_{4}$, ratificando o raciocínio de que os microrganismos autotróficos nitrificantes são mais suscetível à variação de $\mathrm{pH}$, e que necessitam de pH ligeiramente alcalino (ABREU, 1994; VON SPERLING, 1997; METCALF \& EDDY, 2003; FERREIRA, 2002; JORDÃO \& PESSÔA, 2014). 


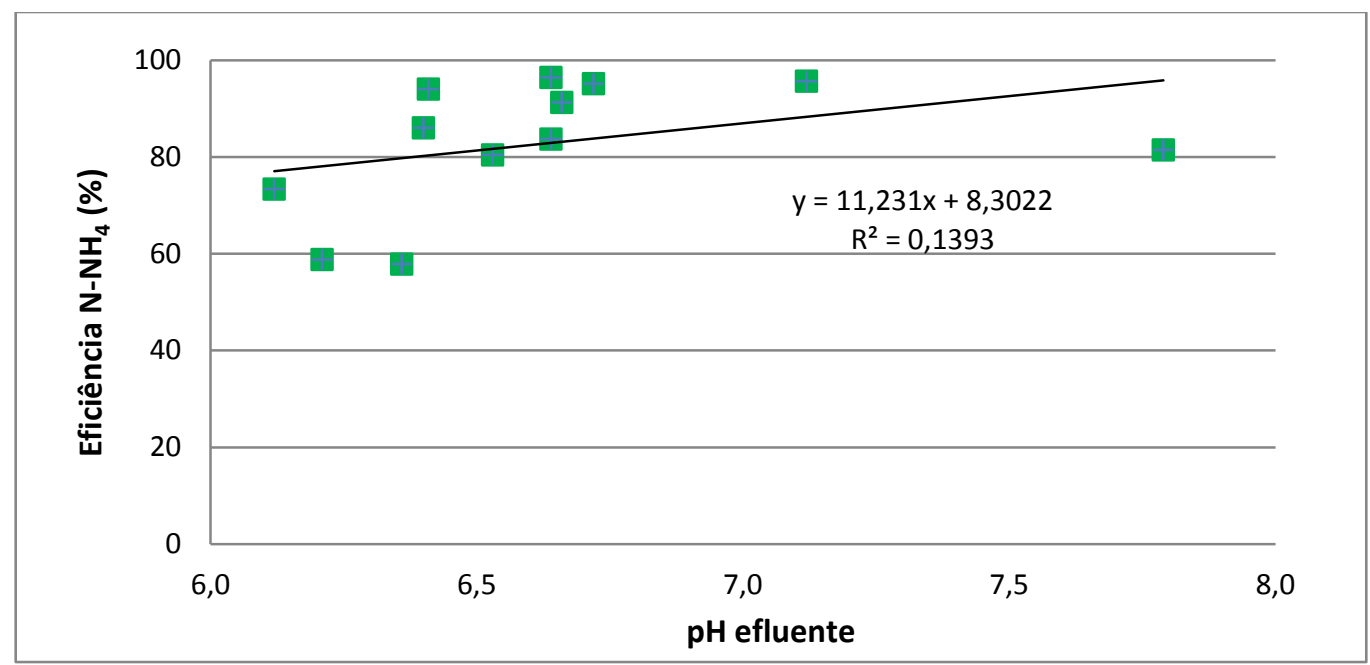

Figura 5.48: Eficiência $\mathrm{N}-\mathrm{NH}_{4}$ versus pH efluente - IFAS 2(após a repartida)

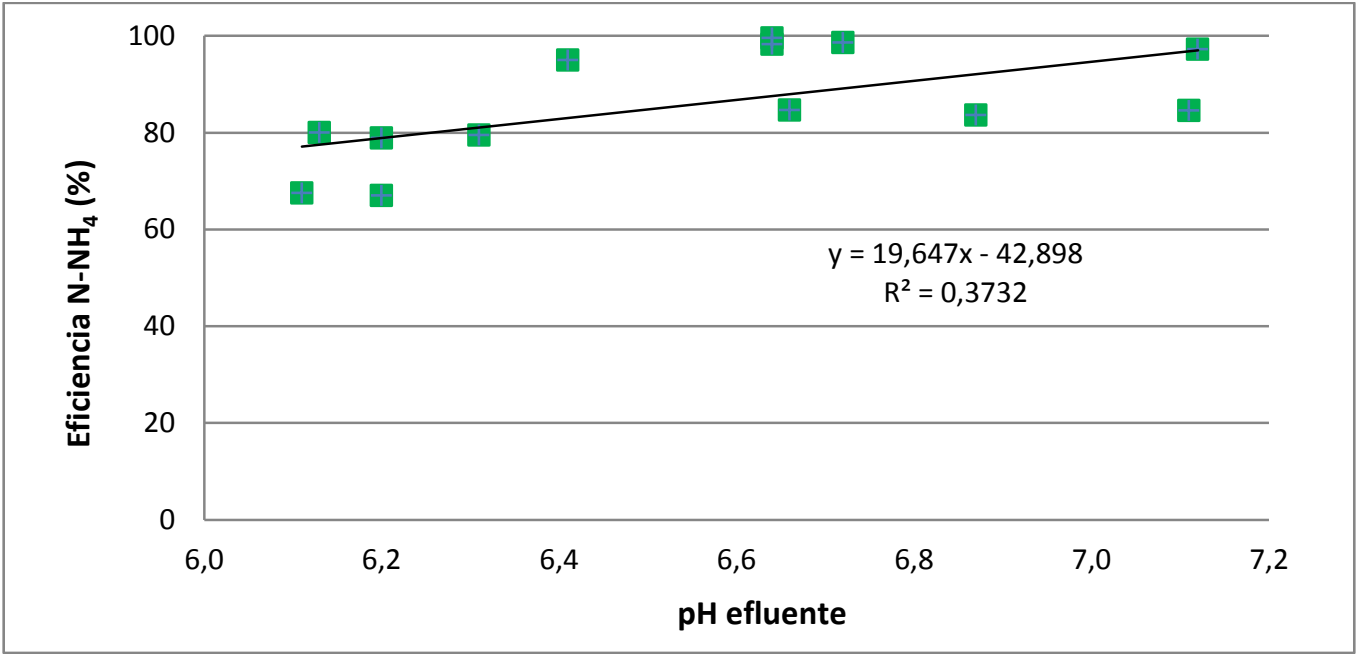

Figura 5.49:Eficiência $\mathrm{N}-\mathrm{NH}_{4}$ versus pH efluente-IFAS 3(após a repartida)

Para a tecnologia MBBR/IFAS trabalhando de forma a promover a SND, XING et. al (2000) sugere relação C/N igual a 10. Por outro lado, FU et al. (2010) alcançaram melhores eficiências médias de remoção de DQO e NT para uma razão C/N de 13,4.

Nesse contexto, os gráficos das Figuras 5.50 e 5.51 ilustram o comportamento da eficiência de remoção de $\mathrm{N}-\mathrm{NH}_{4}$ com a variação da relação C/NTK. Repara-se que, praticamente não houve uma relação direta entre a remoção de $\mathrm{N}-\mathrm{NH}_{4}$ e da relação C/NTK. 


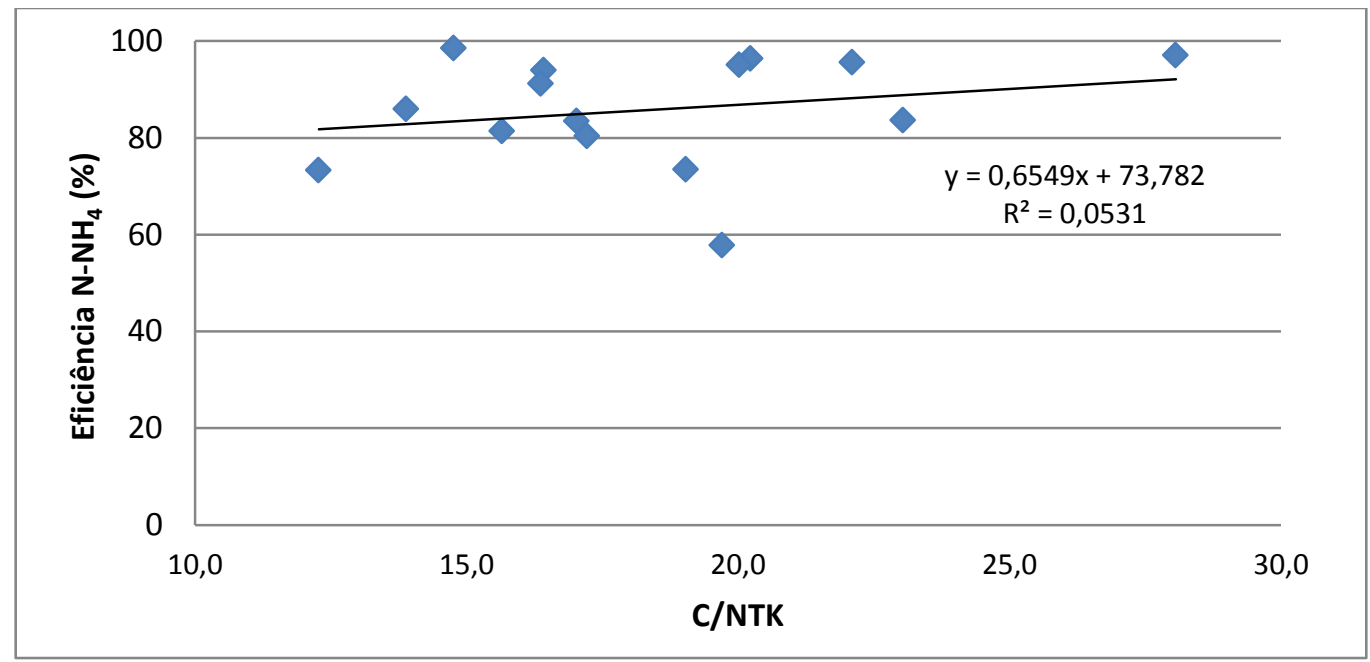

Figura 5.50: Eficiência N-NH 4 versus relação C/NTK - IFAS 2 (após a repartida)

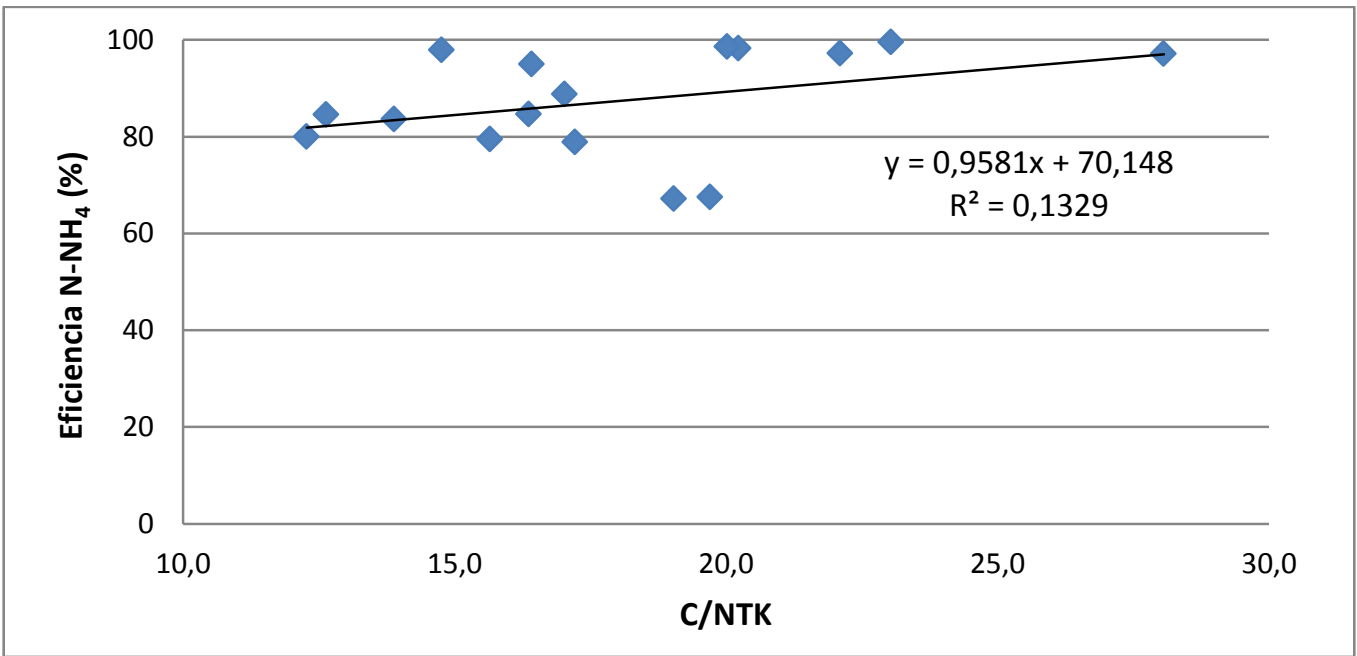

Figura 5.51: Eficiência N-NH 4 versus relação C/NTK - IFAS 3 (após a repartida)

Não obstante, pode-se notar por meio dos gráficos das Figuras 5.52 e 5.53 que,quanto maior foi a carga superficial de $\mathrm{N}-\mathrm{NH}_{4}\left(\mathrm{gN}-\mathrm{NH}_{4} \mathrm{~m}^{-2} \mathrm{~d}^{-1}\right)$ mais elevada foi a taxa de nitrificação(gN-NH$H_{4}$ rem. $m^{-2} d^{-1}$ ). 


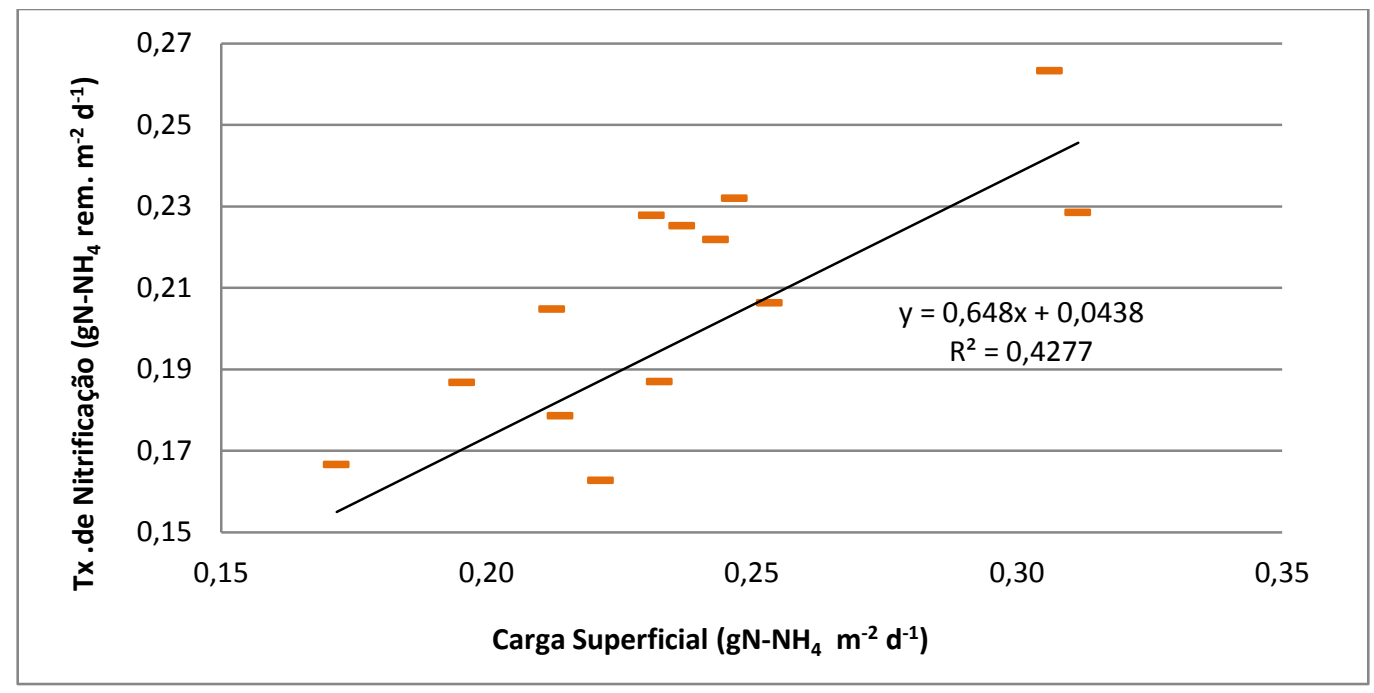

Figura 5.52: Taxa de NitrificaçãoversusCarga Superficial de N-NH 4 - IFAS 2 (após a repartida)

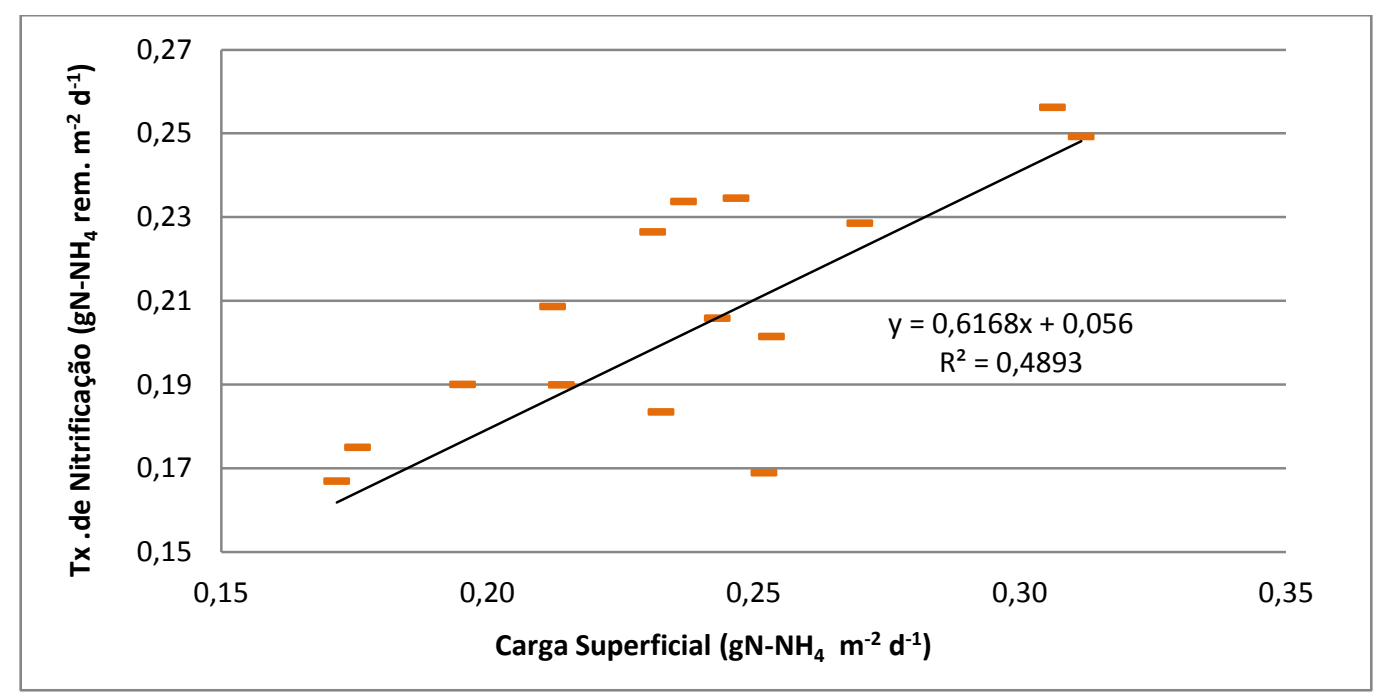

Figura 5.53:Taxa de Nitrificação versus Carga Superficial de N-NH - IFAS 3 (após a repartida)

Vale ressaltar que o valor médio de carga superficial de $\mathrm{N}-\mathrm{NH}_{4}$ foi de $0,23 \mathrm{gN}-\mathrm{NH}_{4} \mathrm{~m}^{-2} \mathrm{~d}^{-1}$, correspondente a uma taxa de nitrificação média igual a $0,19 \mathrm{gN}-\mathrm{NH}_{4} \mathrm{rem} \cdot \mathrm{m}^{-2} \mathrm{~d}^{-1}$ para o reator IFAS 2 e de $0,23 \mathrm{gN}-\mathrm{NH}_{4} \mathrm{~m}^{-2} \mathrm{~d}^{-1}$, que equivale a uma taxa de nitrificação média igual a 0,20 gN-NH 4 rem. $\mathrm{m}^{-2} \mathrm{~d}^{-1}$ para o reator IFAS 3. Quando serelaciona esses valores com os obtidos por RUSTENet. al(1995) (Figura 3.7), verifica-seque houve o mesmo comportamento, indicando ainda que praticamente toda carga de $\mathrm{N}-\mathrm{NH}_{4}$ aplicada foi consumida/removida. 
Diante disso, analisando agoraa remoção de NT, nota-se que houve uma remoção média igual a $66 \%$ e $71 \%$ para os reatores IFAS 2 e IFAS 3, respectivamente, considerando a parcela assimilada ao lodo em excesso.

Avaliando os resultados de remoção de NTem conjunto com a emissão de $\mathrm{N}_{2} \mathrm{O}$ nos reatores IFAS 2 e IFAS 3, conforme ilustram as Figuras 5.54 e 5.55 respectivamente, podese indicar que todo o nitrogênio removido foi na forma de $N_{2}$. Visto que, obteve-se uma emissão média $\mathrm{N}_{2} \mathrm{O}$ de $0,016 \mathrm{mg} \mathrm{N} \mathrm{h}^{-1}$, equivalente a somente $0,15 \%$ do $\mathrm{NTK}$ afluentepara o reator IFAS 2 , e de $0,013 \mathrm{mg} \mathrm{N} \mathrm{h}^{-1}$, que corresponde a $0,12 \%$ do NTK afluentepara o reator IFAS 3.

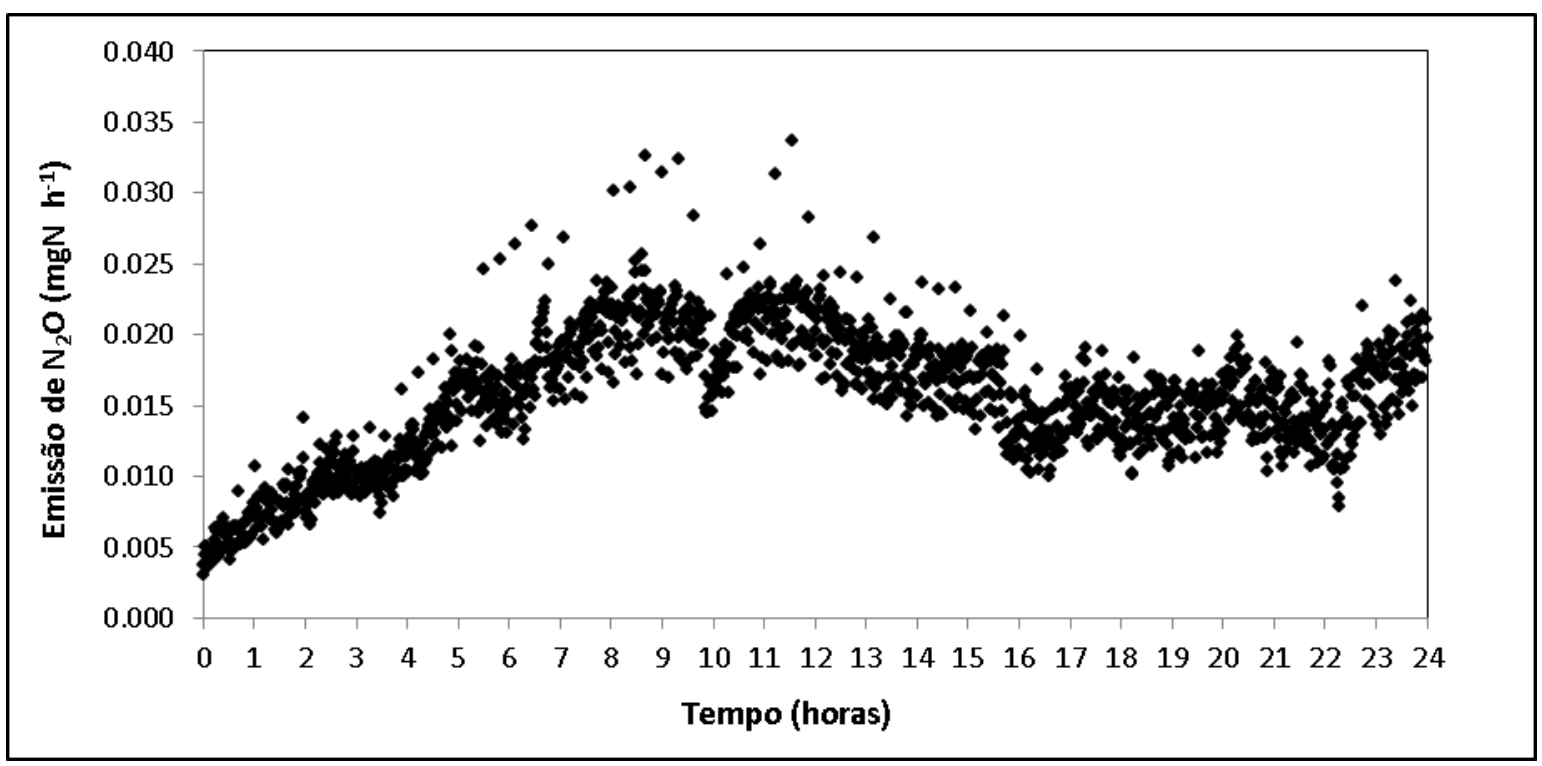

Figura 5.54: Emissão de $\mathrm{N}_{2} \mathrm{O}$ ao longo do período de monitoramento - IFAS 2(após repartida)

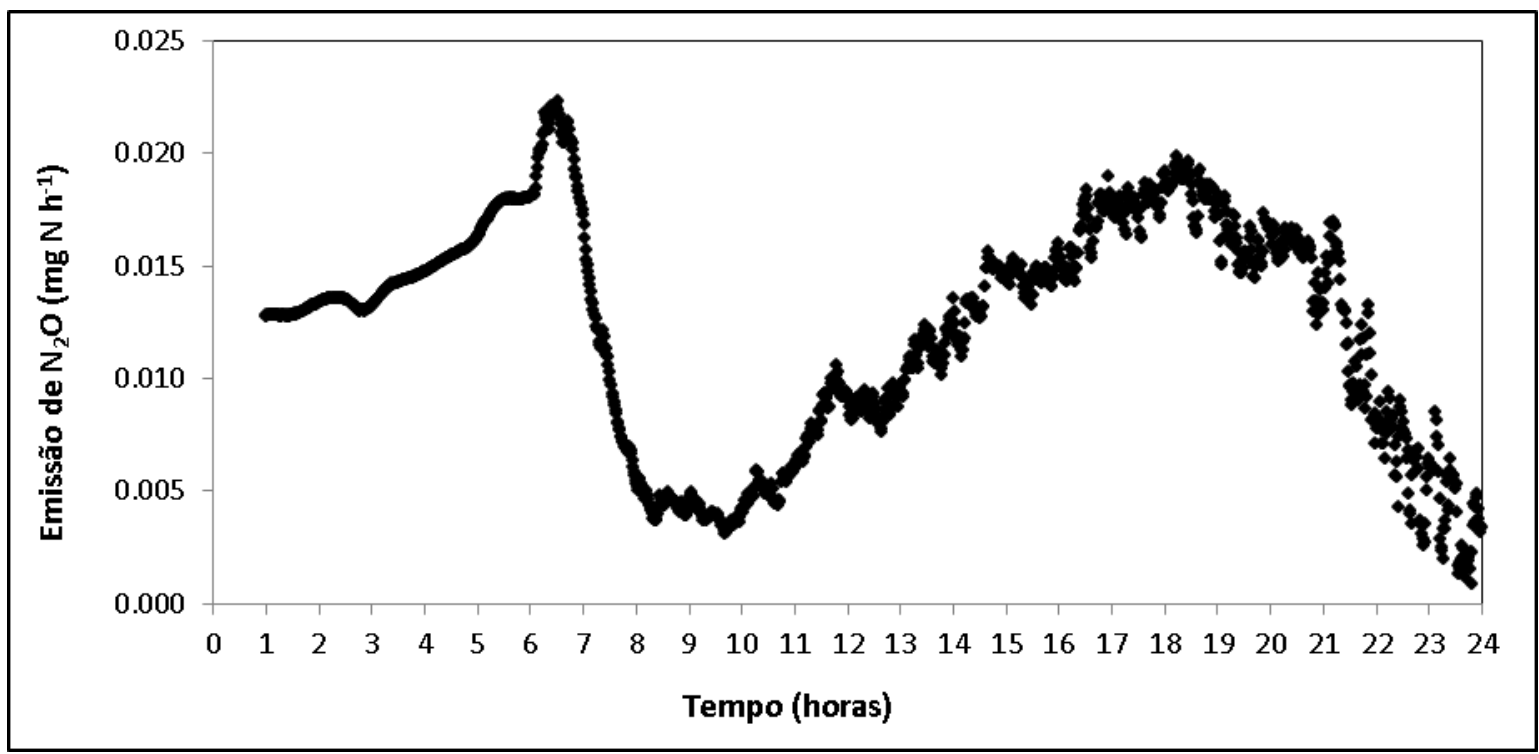


Figura 5.55: Emissão de $\mathrm{N}_{2} \mathrm{O}$ ao longo do período de monitoramento - IFAS 3(após repartida)

É importante deixar claro que,caso fosse avaliado a SND conforme indica a literatura, ou seja, sem realização do balanço dos compostos nitrogenados da forma que foi feito e, principalmente, sem examinar a emissão de $\mathrm{N}_{2} \mathrm{O}$, a sua performance seria somente em função da remoção NT e/ou com indicação da eficiência de remoção de $\mathrm{N}-\mathrm{NH}_{4}$ ou ainda apenas em relação dasconcentrações efluente deN- $\mathrm{NO}_{2} \mathrm{e} \mathrm{N}-\mathrm{NO}_{3}$.

Nesse caso, tem-se assim, remoções de NT de 68\% e 73\% para os reatores IFAS 2 e IFAS 3, respectivamente; oueficiências de remoção de $\mathrm{N}^{-N_{4}}$ igual a $84 \%$ e $86 \%$, equivalente a concentrações efluente de $5,5 \mathrm{mg} \mathrm{L}^{-1}$ e $4,9 \mathrm{mg} \mathrm{L}^{-1}$; ou concentrações efluente de $\mathrm{N}-\mathrm{NO}_{2}$ iguais a $0,23 \mathrm{mg} \mathrm{L}^{-1}$ e $0,09 \mathrm{mg} \mathrm{L}^{-1}$ e de $\mathrm{N}-\mathrm{NO}_{3}$ de $4,49 \mathrm{mg} \mathrm{L}^{-1}$ e 4,14 $\mathrm{mg} \mathrm{L}^{-1}$, considerando respectivamente os reatores IFAS 2 e IFAS 3.

De qualquer maneira, os resultados alcançados nesse trabalho foram similares aos obtidos por ZHANG et. al, (2007), XING et. al,(2000) e BUENO (2011); superiores aos de KRICHTEN \& MCDOWELL (2003) e inferiores aos alcançados por THAURÉ et al. (2008), WANG et al. (2006) e FU et al. (2010). Lembrando que destes, somente WANG et al. (2006) e FU et al. (2010) empregaram o sistema MBBR e apenas WANG et al. (2006) utilizou esgoto doméstico.

\subsubsection{Parâmetros Operacionais e de Controle}

Apresenta-se na Tabela 5.14 os principais parâmetros operacionais e de controleobtidos para os reatores IFAS 1 e IFAS 2 e IFAS 3, considerando exclusivamente após a repartida. Uma vez que, a queda do $\mathrm{pH}$ influenciou enormemente a biomassa dos reatores e, consequentemente, os parâmetros operacionais e de controle.

Tabela 5.14: Resultados dos principais parâmetros operacionais e de controle - Fase 2.2 Reatores IFAS 1 e IFAS 2 e IFAS 3 (após a repartida)

\begin{tabular}{|c|c|c|c|}
\hline \multirow{2}{*}{ Parâmetros } & \multirow{2}{*}{ IFAS 1} & \multicolumn{2}{|c|}{ Após repartida } \\
\hline & & IFAS 2 & IFAS 3 \\
\hline $\mathrm{A} / \mathrm{M}\left(\mathrm{kg}\right.$ DQO ou DQOsol kg SSV$\left.{ }^{-1} \mathrm{~L}^{-1}\right)$ & $3,0^{4}\left(0,14^{1}\right)$ & $7,98^{4}\left(0,22^{1}\right)$ & $7,33^{4}\left(0,19^{1}\right)$ \\
\hline $\cos \left(g \mathrm{DQO} \mathrm{m}^{-2} \mathrm{~d}^{-1}\right)$ & $3,7\left(2,04^{2}\right)$ & $4,4\left(0,48^{2}\right)$ & $4,4\left(0,51^{2}\right)$ \\
\hline $\mathrm{DBA}\left(\mathrm{mg} \mathrm{SSV} \mathrm{L}^{-1}\right)$ & $6.565\left(1.351^{2}\right)$ & $6.228\left(2.210^{2}\right)$ & $6.334\left(1.178^{2}\right)$ \\
\hline
\end{tabular}




\begin{tabular}{|c|c|c|c|}
\hline Biomassa aderida $\left(\mathrm{g} \mathrm{m}^{-2}\right)$ & $20,2\left(5,01^{2}\right)$ & $19,8\left(3,9^{2}\right)$ & $20,1\left(2,2^{2}\right)$ \\
\hline SSVTA (mg SSV L ${ }^{-1}$ ) & 265 & 243 & 327 \\
\hline $\mathrm{SSV} / \mathrm{SST}^{3}(\%)$ & $73 ; 78$ & $75 ; 76$ & $78 ; 80$ \\
\hline Idade do Lodo (dias) & 15 & 24 & 16 \\
\hline pH (entrada - saída) & $7,3-6,9$ & $8,1-6,5$ & $8,1-6,6$ \\
\hline Temperatura (으) & 24,1 a 26,8 & 23,7 a 27,2 & 23,7 a 27,2 \\
\hline $\operatorname{IVL}\left(\mathrm{mL} \mathrm{g}^{-1}\right)$ & 90 a 130 & - & - \\
\hline
\end{tabular}

1 Biomassa total (aderida + suspensa)

${ }^{2}$ Desvio Padrão

${ }^{3}$ SSV/SST em suspensão; SSV/SST aderido

${ }^{4}$ SomenteBiomassa em suspensão

Observa-se que os valores da razão A/M obtidos nos reatores IFAS 2 elFAS 3, considerando somente a biomassa em suspensão, foram mais que o dobro do encontrado no reator IFAS 1; isto porque o efluente sintético possuiu concentração de DQO bem superior quando comparado com o efluente sanitário empregado no reator IFAS 1.

Todavia, avaliando-se os valores de $\mathrm{A} / \mathrm{M}$ dado pela biomassa total, nota-se que foram equivalentes para os reatores IFAS 2 e IFAS 3e, estes superiores ao A/M doreator IFAS 1.

Ressalta-se que essa diferença da DBA nos reatores IFAS 1 e IFAS 3 pode ser em virtude da maior concentração de OD $\left(1,5 \mathrm{mg} \mathrm{L}^{-1}\right)$ quando comparado com o IFAS $2\left(1,0 \mathrm{mg} \mathrm{L}^{-1}\right)$ e que os valores de DBA do reator IFAS 1 podem terem sidos influenciados pela salinidade. Ou seja, as partículas de sais podem ter ficados adsorvidas na biomassa aderida.

De qualquer modo, percebe-se que os valores da DBApara os três reatores foram superiores aos reportados pela literatura (MARÍN-PASCUAL et al. 2015; 2014 e 2012; LEYVA-DÍAZet al. 2013a; 2013b; ANDREOTTOLA et al. 2003b; HONG-BINet al. 2007; MINEGATTII, 2008 e LUOSTARINEN et al. 2006).

Pode-se constatar também que a COS média dos reatores IFAS 2 e IFAS 3 foram mais elevadas, em razão da maior concentração da DQO afluente.

Realça-se ainda que, a relação SSV/SST foi superior na biomassa aderida.

Quanto ao pH, observa-se que, houve uma relativa redução nos reatores IFAS 2 e IFAS 3, inidicando um consumo de alcalinidade dado pelo processo de nitrificação alcançado. 
Por fim, e não menos importante, pode-se constatar que a idade do lodo foi superior no reator IFAS 2 devido principalmente a baixa concentração de biomassa em suspensão e, consequentemente, no lodo de excesso.

Mesmo assim, pode-se concluir que a idade do lodo não foi um fator preponderante para avaliar se há ou não possibilidade de remoção de compostos nitrogenados, mas sim a relação A/M. Visto que, o reator IFAS 2 trabalhou com idade do lodo e A/M mais elevados do que o IFAS 3, obtendo praticamente o mesmo comportamento.

\subsubsection{Variação da alcalinidade}

A variação da alcalinidade $\left(\mathrm{CaCO}_{3}\right)$ devido à nitrificação e desnitrificação, ocorridas nesta fase, foram calculadas conforme descrito no item 3.2.6. Na Tabela 5.15 são apresentados a variação da alcalinidade teórica (estequiométrica) e a observada no sistema, causada pelo efeito combinado da nitrificação e desnitrificação. Salienta-se que a variação da alcalinidade devido a amonificação não foi calculada pelo fato do efluentesintético não conter, substancialmente, nitrogênio orgânico afluente e efluente.

Tabela 5.15:Variação da alcalinidade teórica e observada durante a Fase 2.2 - Reatores IFAS 2 e 3 (após a repartida)

\begin{tabular}{ccccc}
\hline \multirow{2}{*}{ Parâmetros } & \multicolumn{2}{c}{ IFAS 2 } & \multicolumn{2}{c}{ IFAS 3 } \\
\cline { 2 - 5 } & $\mathbf{\Delta} \mathbf{a l c}_{\mathbf{t}}$ & $\Delta$ alc $_{\text {obs }}$ & $\Delta \mathbf{a l c}_{\mathbf{t}}$ & $\Delta$ alc $_{\text {obs }}$ \\
\hline Média & $-94,1$ & $-111,3$ & $-85,3$ & $-108,5$ \\
Máximo & $-6,4$ & $-0,7$ & $-11,8$ & $-10,9$ \\
Mínimo & $-131,8$ & $-256,0$ & $-118,5$ & $-266,7$ \\
Desvio Padrão & 32,2 & 70,0 & 27,2 & 70,6 \\
Coeficiente de Variação & $-0,3$ & $-0,7$ & $-0,3$ & $-0,7$ \\
\hline
\end{tabular}

$\Delta$ alc $c_{\mathrm{t}}=$ Variação da alcalinidade teórica

$\Delta \mathrm{alc}_{\mathrm{obs}}=$ Variação da alcalinidade observada

Nota-se que, os valores médiosda variação da alcalinidade teórica e observada são semelhantes em ambos reatores, apesar da dispersão dos dados, demonstrada pelo Desvio Padrão e Coeficiente de Variação. Analisando estatisticamente por meio do test $t$, como descrito no Item 4.5.5, indica-se que não houve diferença entre os resultados, $\mathrm{P}$ igual a 0,76 e 0,25 considerando a reator IFAS 2 e IFAS 3, respectivamente, e um nível de significância de $95 \%$. 
Desse modo, conclui-se que o balanço de alcalinidade no sistema torna-se compatível com a ocorrência simultânea do processo de nitrificação e desnitrificação e, dependendo da concentração de amônia e da alcalinidade no afluente, torna-se necessário a introdução de mais alcalinizante (Bicarbonato de Sódio), para não ocorrer limitações no processo de SND.

\subsection{Avaliação entre Etapa 1 e Etapa 2}

Primeiramente, apresenta-se na Tabela 5.16 as eficiências médias obtidas dos principais parâmetros monitorados (DQO, DQOsol, $\mathrm{N}-\mathrm{NH}_{4}$ e NTK) para asFases 1.2, 2.1 e 2.2 e os respectivos reatores. Considerou-se somente essas fases porque a Fase 1.1 foi, praticamente, uma fase de aclimatação. E, os reatores IFAS 2 e IFAS 3 na Fase 2.2 serão avaliados a parte pelo fato de terem utilizados efluente sintético.

Em vista disso, os principaisparâmetrosde controle sujeitos a variaçãodentre essas fases foram o TDH e, especialmente, a concentração de OD.

Tabela 5.16:Eficiências médias de remoção dos principais parâmetros para as Fase 1.2 IFAS 1; Fase 2.1 - IFAS 1; Fase 2.1 - IFAS 2; Fase 2.1 - IFAS 3 e Fase 2.2 - IFAS 1

\begin{tabular}{|c|c|c|c|c|c|c|}
\hline Fases - Reatores & $\mathrm{OD}\left(\mathrm{mg} \mathrm{L}^{-1}\right)$ & TDH (h) & Ef. DQO (\%) & Ef. DQOsol (\%) & Ef. $\mathrm{N}-\mathrm{NH}_{4}(\%)$ & Ef. NTK (\%) \\
\hline Fase 1.2 - IFAS 1 & 2,4 & 5,5 & 77 & 67 & 54 & 59 \\
\hline Fase 2.1 - IFAS 1 & 2,0 & 11 & 85 & 62 & 45 & 45 \\
\hline Fase 2.1 - IFAS 2 & 1,0 & 11 & 75 & 68 & 46 & 52 \\
\hline Fase 2.1 - IFAS 3 & 1,5 & 11 & 72 & 69 & 39 & 55 \\
\hline Fase 2.2 - IFAS 1 & 1,5 & 11 & 69 & 58 & 73 & 66 \\
\hline
\end{tabular}

Na Tabela 5.17são apresentados os resultados dos valores de $P$ (considerando nível de significância de $95 \%$ ou $P<0,05)$ para as fases e reatores avaliados, considerando as eficiências de remoção obtidas para os parâmetros supracitados. 
Tabela 5.17:Valores de Ppara as principais fases e parâmetros monitorados

\begin{tabular}{|c|c|c|c|c|c|}
\hline \multirow[b]{2}{*}{ Parâmetros } & \multirow{2}{*}{$\begin{array}{c}\text { Fases Operacionais } \\
\text { - Reatores }\end{array}$} & \multicolumn{4}{|c|}{ Fases Operacionais - Reatores } \\
\hline & & $\begin{array}{l}\text { Fase } 2.1 \\
\text { IFAS } 1\end{array}$ & $\begin{array}{l}\text { Fase } 2.1 \\
\text { IFAS } 2\end{array}$ & $\begin{array}{l}\text { Fase } 2.1 \\
\text { IFAS } 3\end{array}$ & $\begin{array}{l}\text { Fase } 2.2 \\
\text { IFAS } 1\end{array}$ \\
\hline \multirow{5}{*}{ DQO } & Fase 1.2 & $\underline{0.01746}$ & 0.64161 & 0.33531 & 0.41702 \\
\hline & Fase 2.1 IFAS 1 & - & $\underline{0.03487}$ & $\underline{0.01235}$ & 0.06708 \\
\hline & Fase 2.1 IFAS 2 & - & - & 0.69258 & 0.62380 \\
\hline & Fase 2.1 IFAS 3 & - & - & - & 0.80494 \\
\hline & Fase 2.2 IFAS 1 & - & - & - & - \\
\hline \multirow{5}{*}{ DQOsol } & Fase 1.2 & 0.99262 & 0.24473 & 0.79006 & 0.21195 \\
\hline & Fase 2.1 IFAS 1 & - & 0.36130 & 0.84527 & 0.30191 \\
\hline & Fase 2.1 IFAS 2 & - & - & 0.39096 & $\underline{0.04335}$ \\
\hline & Fase 2.1 IFAS 3 & - & - & - & 0.16886 \\
\hline & Fase 2.2 IFAS 1 & - & - & - & - \\
\hline \multirow{5}{*}{$\mathrm{N}-\mathrm{NH}_{4}$} & Fase 1.2 & 0.27031 & 0.47328 & 0.10174 & $\underline{0.01843}$ \\
\hline & Fase 2.1 IFAS 1 & - & 0.94855 & 0.52830 & $\underline{0.00160}$ \\
\hline & Fase 2.1 IFAS 2 & - & - & 0.58957 & $\underline{0.03039}$ \\
\hline & Fase 2.1 IFAS 3 & - & - & - & $\underline{0.00093}$ \\
\hline & Fase 2.2 IFAS 1 & - & - & - & - \\
\hline \multirow{5}{*}{ NTK } & Fase 1.2 & 0.05430 & 0.78461 & 0.84857 & 0.33832 \\
\hline & Fase 2.1 IFAS 1 & - & 0.79839 & 0.71017 & $\underline{0.00819}$ \\
\hline & Fase 2.1 IFAS 2 & - & - & 0.93234 & 0.62742 \\
\hline & Fase 2.1 IFAS 3 & - & - & - & 0.66626 \\
\hline & Fase 2.2 IFAS 1 & - & - & - & - \\
\hline
\end{tabular}

Nota-se que, de maneira geral, houvepoucas diferenças significativas entre os reatores/fases. Especificamente, para a eficiência de remoção DQO, houve diferença significativa entre a Fase 1.2 e Fase 2.1 - IFAS 1 (valor de $P=0,01746$ ); Fase 2.1 - IFAS 1 e Fase 2.1 - IFAS 2 (valor de $P=0,03487$ ) e Fase 2.1 - IFAS 1 e Fase 2.1 - IFAS 3 (valor de $P=$ 0,01235). Em relação a DQOsol, apenas houve diferença significativa entre as Fase 2.1 IFAS 2 e Fase 2.2 - IFAS 1 (valor de $P=0,04335$ ).

Considerando o nitrogenio amoniacal, observa-se que,somenteo reator IFAS 1 da Fase 2.2 obteve diferença significativa diante dos demais reatores/fases. De fato, a eficiências média de remoção de $\mathrm{N}-\mathrm{NH}_{4}$ do reator IFAS 1 da Fase 2.2 foi de $73 \%$, enquanto dos outros reatores/fasesforam iguais ou inferiores a $54 \%$.

Por fim, avaliando os resultados de NTK, apenaso reator IFAS 1 da Fase 2.1 (eficiência de 45\%) que teve diferença significativa do reator IFAS 1 da Fase 2.2 (eficiência igual a 66\%). 
Diante disso, pode-se concluir que, mesmo com o reator IFAS 1 - Fase 2.2 trabalhando sob diversos choques de salinidade, ele se sobressaiu dentre os demais em relação a remoção de $\mathrm{N}-\mathrm{NH}_{4}$, indicando que os microrganismos nitrificantes podem ter se adaptado a salinidade, conforme assinala BASSIN et. al (2012).

Neste momento, apresenta-se na Tabela 5.18 as eficiências e concentrações médiasefluente obtidas para os principais parâmetros monitorados na Fase 2.2 - Reatores IFAS 2 e IFAS 3. Desse modo, o únicoparâmetro que difere os reatores é a concentração de OD. Já a Tabela 5.19apresenta os resultados dos valores de $P$.

Tabela 5.18: Eficiências médias de remoção e concentração média efluente dos principais parâmetros para a Fase 2.2 - Reatores IFAS 2 e IFAS 3

\begin{tabular}{|c|c|c|c|c|c|}
\hline Fases - Reatores & Ef. DQOsol (\%) & Ef. $\mathrm{N}-\mathrm{NH}_{4}(\%)$ & Ef. NTK (\%) & $\mathrm{N}-\mathrm{NO}_{2}\left(\mathrm{mg} \mathrm{L}^{-1}\right)$ & $\mathrm{N}-\mathrm{NO}_{3}\left(\mathrm{mg} \mathrm{L}^{-1}\right)$ \\
\hline Fase 2.2 - IFAS 2 & 91 & 84 & 81 & 0,23 & 4,49 \\
\hline Fase 2.2 - IFAS 3 & 93 & 86 & 82 & 0,09 & 4,14 \\
\hline
\end{tabular}

Tabela 5.19:Valores de $P$ para os principais parâmetros avaliadospara a Fase 2.2 Reatores IFAS 2 e IFAS 3

\begin{tabular}{lccccc}
\hline & \multicolumn{5}{c}{ Fase 2.2 - IFAS 2 } \\
\cline { 2 - 6 } Fases - Reatores & \multicolumn{5}{c}{ Parâmetros } \\
\cline { 2 - 6 } & DQOsol & $\mathbf{N}-\mathbf{N H}_{4}$ & NTK & $\mathbf{N}-N_{2}$ & N-NO \\
\hline Fase 2.2 - IFAS 3 & 0,1952 & 0,6295 & 0,8254 & 0,2924 & 0,6189 \\
\hline
\end{tabular}

De acordo com os valores de $P$ encontrados, nota-se que não houve diferença significativa entre nenhum dos parâmetros avaliados nos reatores IFAS 2 e IFAS 3. Indicando assim que a concentração de OD não influenciou na performance do processo.

Ademais, conclui-se que, como mencionado anteriormente, a idade do lodo não foi um parâmetro fundamental para indicar o potencial de nitrificação do processo como ocorre no sistema de lodos ativados. Visto que, os microrganismos nitrificantes, de crescimento lento, podem permanecer no sistema por um elevado período de tempo ao se apropriarem do meio suporte (biofilme), como sugere SRIWIRIYARAT \& RANDALL (2005) E 
KERMANlet. al(2008). Sendo isso comprovado pelos resultados obtidos a partir da repartida dos reatores IFAS 1 e IFAS 2.

Neste contexto, é recomendável e mais usual, utilizar a relação a $\mathrm{A} / \mathrm{M}$ como parâmetro de projeto e controle para a tecnologia IFAS/MBBR.

Finalmente, segundo observado por RUSTENet. al (1995), foi possível avaliar o comportamento da nitrificação(eficiência de remoção de $\mathrm{N}-\mathrm{NH}_{4}$ ) com a variação da concentração de ODdurante toda a pesquisa, conforme ilustra o gráfico da Figura 5.56, considerando somente as Fases 1.1; 1.2 e 2.1.

Observa-se que, mesmo com toda adversidade enfrentada pelos reatores, a performance do processo em relação a a nitrificação foi como esperado. Ou seja, quanto maior a concentração de OD mais elevada é nitrificação.

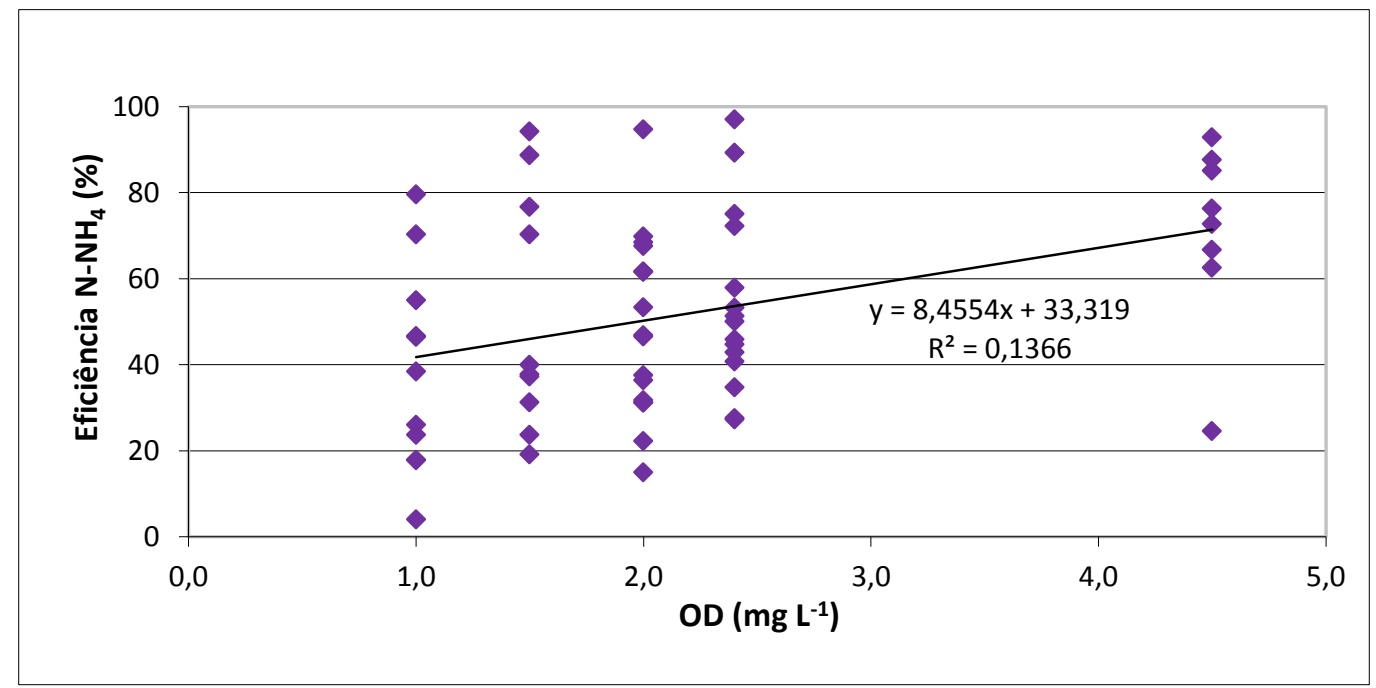

Figura 5.56: Taxa de Nitrificação versus Concentracao de OD

\subsection{Emissão de $\mathrm{N}_{2} \mathrm{O}$}

Primeiramente, é importante evidenciar que no processo de desnitrificação via nitrato, o nitrogênio passa por vários níveis de oxidação, em que ocorrem as seguintes etapas:

$$
\mathrm{NO}_{3} \rightarrow \mathrm{NO}_{2} \rightarrow \mathrm{NO} \rightarrow \mathrm{N}_{2} \mathrm{O} \rightarrow \mathrm{N}_{2}
$$

O pH ótimo está na faixa de 6,5 a 8,0 (METCALF e EDDY, 2003). A velocidade de desnitrificação é reduzida em valores de pH abaixo de 6,0 e acima de 9,0 (SURAMPALLI et al., 1997), principalmente devido ao aumento da produção de óxidos nítricos que são 
inibidores do processo. Em valores de $\mathrm{pH}$ abaixo de 7, pode haver aumento da produção de $\mathrm{N}_{2} \mathrm{O}$ como produto final da desnitrificação (HENZE et. al, 1997).

Quando a fonte de energia para o processo de desnitrificação é orgânica, a água residuária a ser desnitrificada deve conter carbono orgânico suficiente para promover a conversão de nitrato $\left(\mathrm{NO}_{3}\right)$ a $\mathrm{N}_{2}$ gasoso pelas bactérias.

Normalmente, dentro dos gases produzidos no processo de desnitrificação o Óxido Nítrico (NO) é o que tem menores concentrações. Visto que em contato com uma mínima quantidade de $\mathrm{O}_{2}$ ele é convertido para $\mathrm{NO}_{2}$ (BROTTO, 2011). Desta forma, os principais gases formados são o $\mathrm{N}_{2} \mathrm{O}$ e o $\mathrm{N}_{2}$.

Dito isso, em relação aos resultados obtidos quanto à emissão de $\mathrm{N}_{2} \mathrm{O}$, além dos apresentados anteriormente, realizou-se uma medição intermediária entre as Fases 1.1 e Fase 1.2, denominada adaptação entre Fase 1.1 e Fase 1.2. Assim, foram realizadas 5 medições, sendo: $1^{\mathrm{a}}$ ) durante a Fase $1.1 ; 2^{\mathrm{a}}$ ) durante a adaptação entre Fase 1.1 e Fase

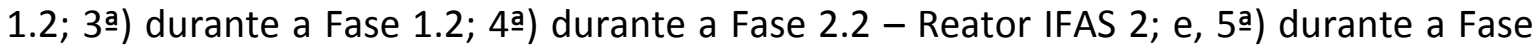
2.2 - Reator IFAS 2, como ilustram os gráficos das Figuras 5.57 a 5.61.

A Tabela 5.20 apresenta, resumidamente, as emissões médias de $\mathrm{N}_{2} \mathrm{O}$ alcançadas e as respectivas porcentagens das cargas médias de NTK afluente que foram convertidas para $\mathrm{N}_{2} \mathrm{O}$.

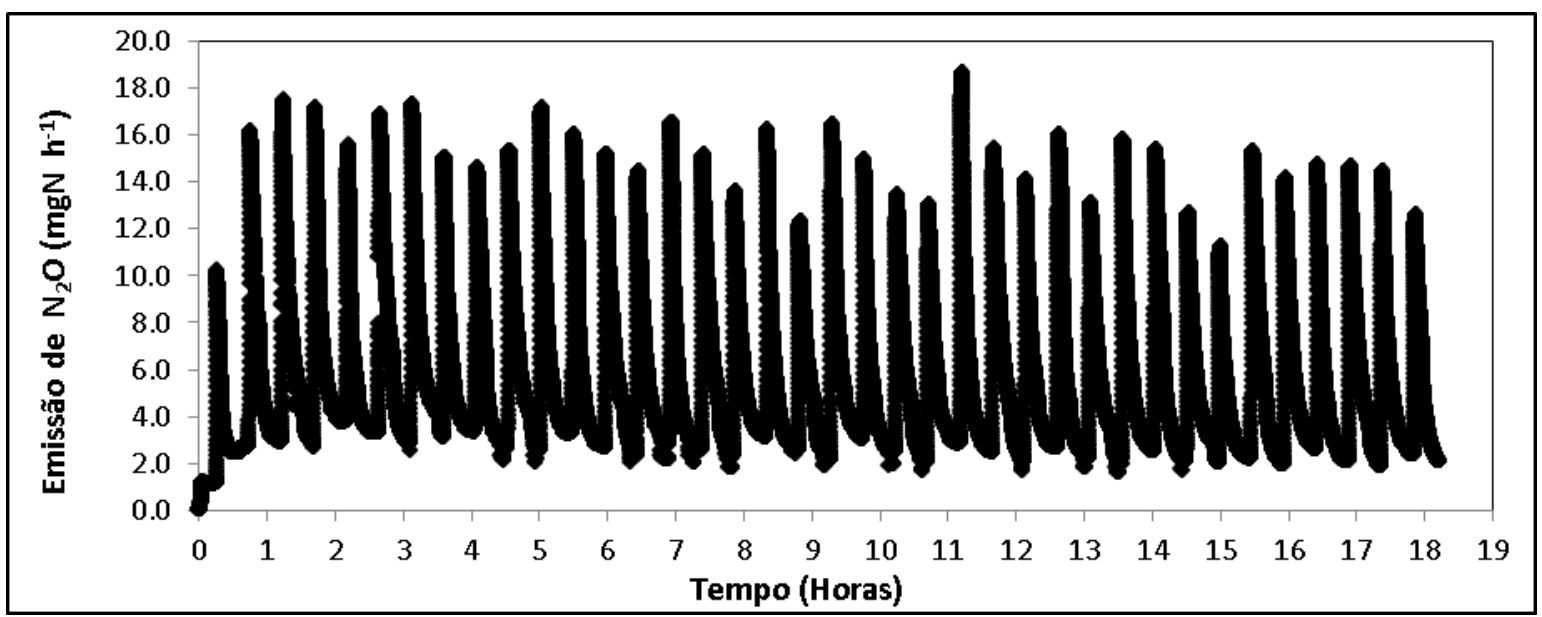

Figura 5.57: Emissão de $\mathrm{N}_{2} \mathrm{O}$ ao longo do período de monitoramento - Fase 1.1 


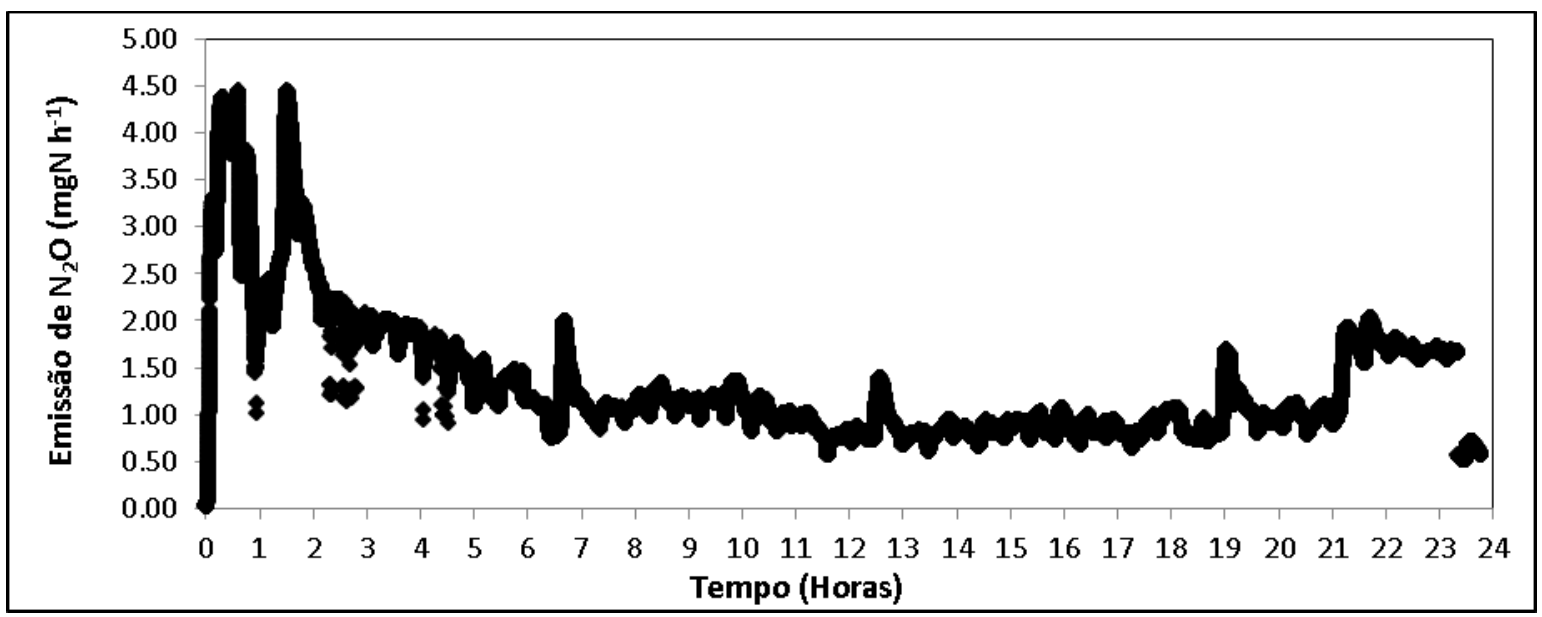

Figura 5.58: Emissão de $\mathrm{N}_{2} \mathrm{O}$ ao longo do período de monitoramento - Adaptação Fase

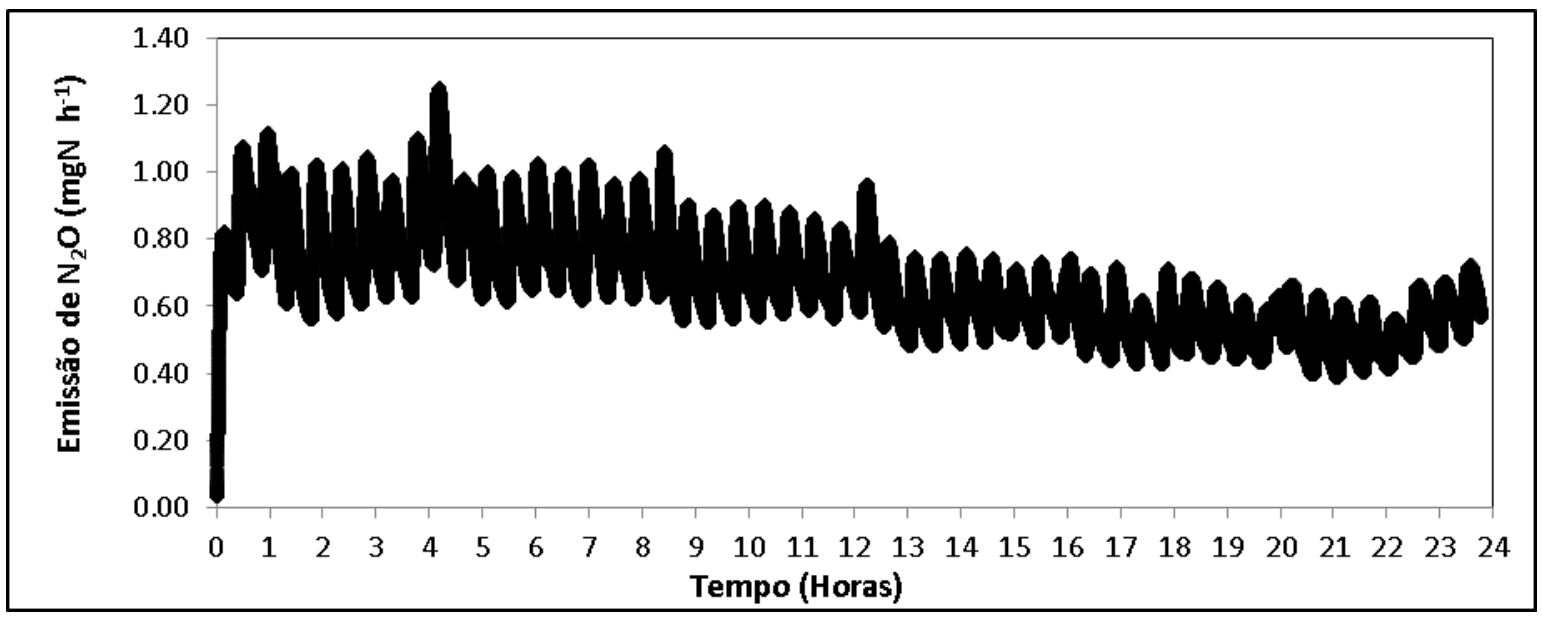

Figura 5.59: Emissão de $\mathrm{N}_{2} \mathrm{O}$ ao longo do período de monitoramento - Fase 1.2

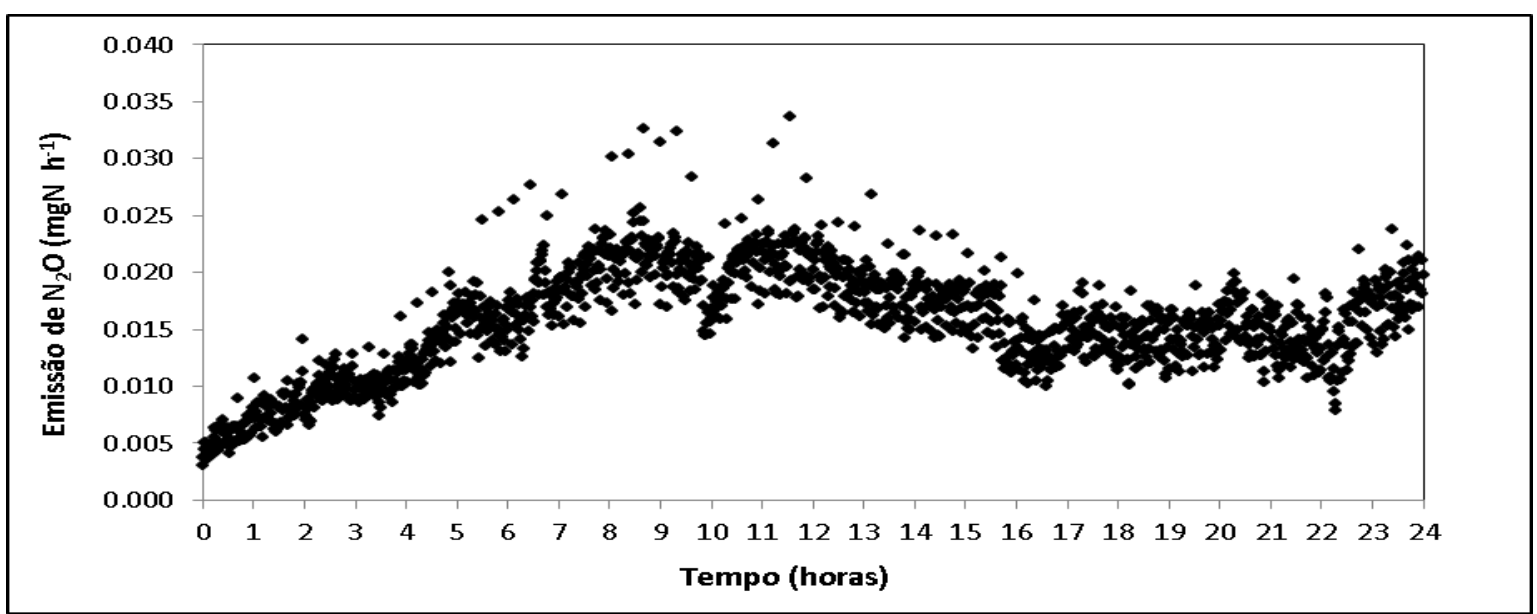

Figura 5.60: Emissão de $\mathrm{N}_{2} \mathrm{O}$ ao longo do período de monitoramento da Fase2.2 - IFAS 2 (após repartida) 


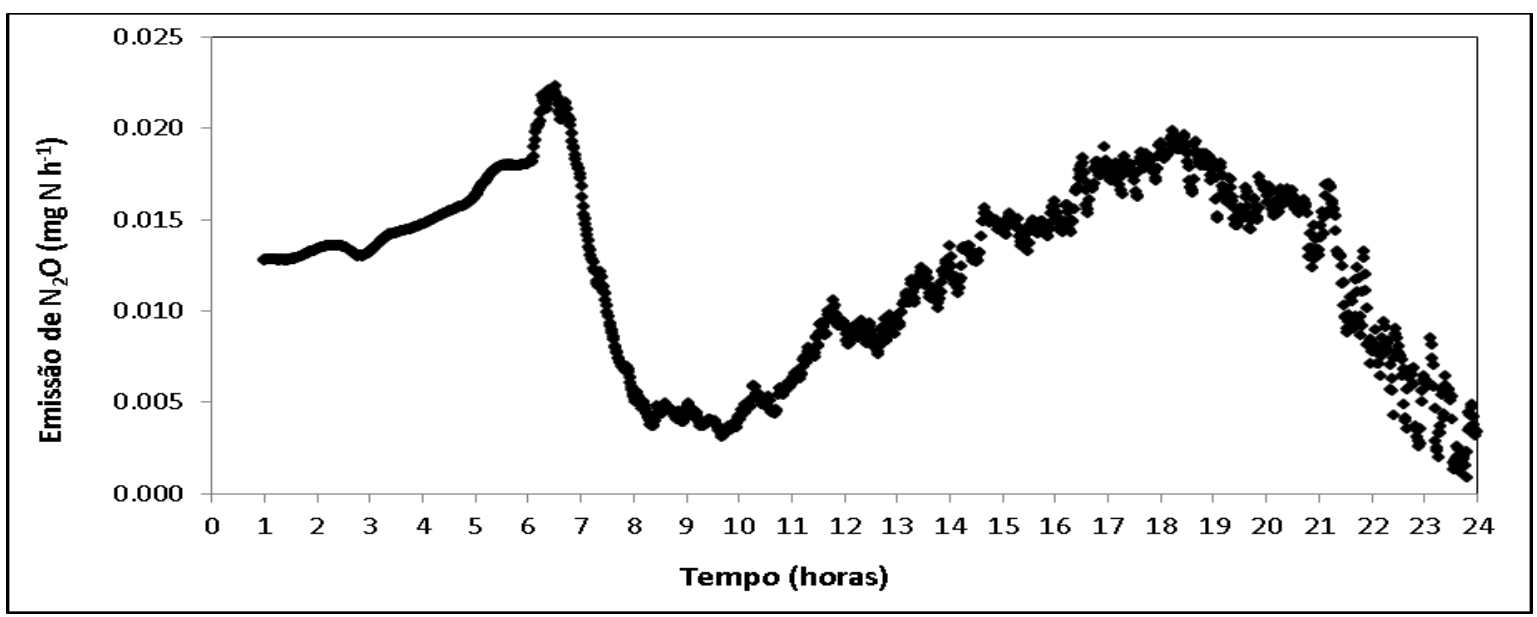

Figura 5.61: Emissão de $\mathrm{N}_{2} \mathrm{O}$ ao longo do período de monitoramento naFase 2.2 -IFAS 3

(após repartida)

Tabela 5.20:Emissões médias de $\mathrm{N}_{2} \mathrm{O}$ e porcentagens das cargas médias NTK afluente que foram convertidas para $\mathrm{N}_{2} \mathrm{O}$ durante as Fases/Reatores monitorados

\begin{tabular}{ccc}
\hline Fases - Reatores & Emissão $\mathbf{~ N}_{\mathbf{2}} \mathbf{O}\left(\mathbf{m g ~ N ~ h}^{-1}\right)$ & \% NTK \\
\hline Fase 1.1 & 5,6 & 5,7 \\
Adap. Fase 1.1 e Fase 1.2 & 1,3 & 2,6 \\
Fase 1.2 & 0,67 & 1,1 \\
Fase 2.2 - IFAS 2 & 0,016 & 0,15 \\
Fase 2.2 - IFAS 3 & 0,013 & 0,12 \\
\hline
\end{tabular}

Com base nesses gráficos, principalmente nos das Figura 5.57 a 5.59, Nota-se que ocorreram picos de emissão de $\mathrm{N}_{2} \mathrm{O}$, causado quando a bomba de reciclo de lodo era acionada. Desta forma, pode-se considerar que havia $\mathrm{N}_{2} \mathrm{O}$ incorporado ao lodo no decantador e, quando o mesmo era recirculado, o $\mathrm{N}_{2} \mathrm{O}$ era purgado no reator devido a aeração.

Nesse contexto, ainda avaliando os gráficos citados, nota-se que ocorreu uma diminuição dos picos de emissão de $\mathrm{N}_{2} \mathrm{O}$ a partir da Fase 1.1 até a Fase 1.2, indicando que houve uma redução de $\mathrm{N}_{2} \mathrm{O}$ contido no lodo. Sendo que isso foi provocado, principalmente, pela redução do intervalo de acionamento da bomba de reciclo de lodo e pelo aumento da vazão de descarte de lodo, que acarretou em um decréscimo da idade do lodo.

De forma geral, percebe-se por meio da Tabela 5.20, que os valores médios de emissão de $\mathrm{N}_{2} \mathrm{O}$ e das respectivas porcentagens das cargas de NTK afluente que foram convertidos a 
$\mathrm{N}_{2}$ Oencontrados foram decrescendo com o andamento da pesquisa, indicando uma melhora no controle operacional e da eficácia do processo de desnitrificação.

Para inventários de emissão de $\mathrm{N}_{2} \mathrm{O}$, o IPCC propõe o uso do fator de emissão (FE) 3,2 g $\mathrm{N}_{2} \mathrm{O}$ pessoa ${ }^{-1}$ ano $^{-1}$ para ETE com processos de nitrificação e desnitrificação controlados, baseado no estudo realizado por CZEPIELet. al, (1995). Entretanto, a United States Environmental Protection Agency (US-EPA) adota o FE 7,0 g N $\mathrm{O}_{2}$ pessoa $^{-1}$ ano $^{-1}$ para o caso de ETE com processos de desnitrificação intencional, e o FE 3,2 g N2O pessoa $^{-1}$ ano $^{-1}$ para ETE com processos de desnitrificação não intencional.

Assim, a partir da vazão aplicado no reator, pode-se obter o equivalente populacional, igual a 40 habitantes para a Fase 1.1 e Fase 1.2, e de 20 habitantes para a Fase 2.2, considerando uma vazão per capta de esgoto de $160 \mathrm{~L} \mathrm{dia}^{-1}$. Assim, adotando asemissões de $\mathrm{N}_{2} \mathrm{O}$ encontradas em cada fase (Tabela 5.20) obtém-se o FE para as diferentes fases operacionais desse experimento, igual a:

- Fase $1.1=1,23 \mathrm{~g} \mathrm{~N}_{2} \mathrm{O}$ pessoa $^{-1} \mathrm{ano}^{-1}$

- Adaptação para Fase $1.2=0,29 \mathrm{~g} \mathrm{~N}_{2} \mathrm{O}$ pessoa $^{-1}$ ano $^{-1}$

- Fase $1.2=0,15 \mathrm{~g} \mathrm{~N}_{2} \mathrm{O}$ pessoa ${ }^{-1} \mathrm{ano}^{-1}$

- Fase 2.2 - IFAS $2=0,007 \mathrm{~g} \mathrm{~N}_{2} \mathrm{O}$ pessoa $^{-1} \mathrm{ano}^{-1}$

- Fase 2.2 - IFAS $3=0,006 \mathrm{~g} \mathrm{~N}_{2} \mathrm{O}$ pessoa $^{-1} \mathrm{ano}^{-1}$

Percebe-se que em nenhuma das fases alcançou-se FE recomendado pelo IPCC ou USEPA, indicando que, quando ocorreu a efetiva remoção de nitrogênio, praticamente todo NTKafluente foi emitido em $\mathrm{N}_{2}$.

Ademais, surge a hipótese que na SND a emissão de $\mathrm{N}_{2} \mathrm{O}$ tende a ser limitada devido ao fato do $\mathrm{N}_{2} \mathrm{O}$ ser convertido novamente a nitrito e/ou nitrato na presença de oxigênio presente no reator, diferentemente do que ocorre nos processos convencionais de remoção de nitrogênio. 


\section{CONCLUSÕES E RECOMENDAÇÕES}

O desenvolvimento deste trabalho resultou em importantes discussões e conclusões relativas ao desempenho e operação do processo IFAS quando trabalhou com efluente sanitário, tais como:

- O processo, apensar dos diversos choques de salinidade ocorridos, manteve uma relativa estabilidade quanto a remoção de matéria orgânica;

- Quanto a remoção de nitrogênio amoniacal, o processo somente obteve certa estabilidade cerca de um ano depois do início de sua operação devido, principalmente, aos choques de salinidade. Sendo que essa equilíbrio pode ter sido alcançada em virtuda da adaptação dos microrganismos frente a salinidade;

- A variação da concentração de OD não interferiu diretamente na eficiência do processo como um todo (matéria orgânica e nitrogênio amoniacal).

Em relação ao processo IFAS desenvolvendo a SNDcom efluente sintético, pode-se concluir que:

- Épossível manter uma baixa concentração de OD no reator, em uma faixa relativamente estreita $\left(0,8\right.$ a $1,2 \mathrm{mg} \mathrm{L}^{-1}$ e 1,3 a $\left.1,7 \mathrm{mg} \mathrm{L}^{-1}\right)$, por meio de um controle automatizado na aeração e, consequentemente, desenvolver a SND sob as mesmas condições e com alta eficiência e estabilidade;

- O processo de nitrificação ocorreu com elevada eficiência, produzindo efluentes com baixas concentrações de nitrogênio amoniacal (inferiores a 4,6 $\mathrm{mg} \mathrm{L}^{-1}$ nos dois reatores), que demonstra que as baixas concentrações de OD foram suficientes para o desenvolvimento estável e eficiente do processo de nitrificação;

- O tratamento resultou em elevadaseficiências na remoção de DQO solúvel, alcançando valores acima de $90 \%$. Demonstrando que a baixa concentração de OD foi suficiente para desenvolvimento do processo de SND e não limitante para remoção do material orgânico;

- Quanto maior a COS aplicada maiores foram aseficiências na remoção da matéria orgânica e menoresas eficiências dos compostos nitrogenados;

- O processo de desnitrificação sucedeu com elevada eficiência em ambos reatores (concentrações de OD). Asconcentrações de nitrato e nitritose mantiveram 
constantes, obtendo valores médiosinferiores a $4,5 \mathrm{mg} \mathrm{L}^{-1}$ para nitrato e $0,23 \mathrm{mg} \mathrm{L}^{-}$ ${ }^{1}$ para nitrito. Conclui-se assim que a concentrações de OD estabelecidas nos reatores não afetou negativamente o processo de desnitrificação;

- A SND ocorreu de forma efetiva e com resultados similares para ambas concentrações de $O D$, indicando que se pode trabalhar comconcentrações da ordem de $1,0 \mathrm{mg} \mathrm{L}^{-1}$ visando menor gasto energético;

- A variação da razão $\mathrm{C} / \mathrm{N}$ não afetou no processo de SND, mas por outro lado, a variação do $\mathrm{pH}$ (choque) influenciou diretamente o processo de nitrificaçãoe consequentemente, a SND;

- Em relação a biomassa presente no sistema, as DBA foram mais elevadas em comparação com os dados da literatura e os de Biomassa aderida superiores ao remomendada pela NBR 12.209, mesmo com o emprego de um sistema de mistura que, teoricamente, aumenta o choque entre os meios suporte, aumentando assim o maior desprendimento da biomassa aderida. A razão SSV/SST foi sempre acima de 0,75 para ambas biomassas, atingindo valores de 0,80 para a biomassa aderida;

- No que se refere a emissão de $\mathrm{N}_{2} \mathrm{O}$, conclui-se que em todas as fases o processo não alcançou o FE proposto pelo IPCC ou EPA para $\mathrm{N}_{2} \mathrm{O}$ e que, quando o processo executou efetivamente a SND, as emissões de $\mathrm{N}_{2} \mathrm{O}$ foram baixíssimas, confirmando a eficiência do processo de desnitrificação.

Para continuidade das pesquisas da tecnologia IFAS, recomenda-se:

- Determinar as constantes cinéticas da nitrificação e desnitrificação para mesma a condição operacional imposta neste trabalho;

- Avaliar detalhadamente o desempenho do processo em meio aos choques de salinidade visando sua adaptação;

- Analisar a SND para outras relações A/M e TDH. 


\section{REFERÊNCIAS BIBLIOGRÁFICAS}

ABREU, L, M. Aspectos microbiológicos de los processos de nitrificación-denitrificación. In: 3ㅇ Taller y Seminario Latino-americano de tratamiento anaeróbio de águas residuales. Montevideo, Uruguay. pp. 55-63. 1994.

AHN, J.H., KIM, S.; PARK, H.; RAHM, B.; PAGILLA, K.; CHANDRAN, K. $\mathbf{N}_{\mathbf{2}} \mathbf{O}$ emissions from activated sludge processes, 2008-2009: results of a national monitoring survey in the United States. Environmental Science and Technology, 44 (12). 2010.

AKUNNA, J.C.; BIZEAU, C.; MOLETTA, R. Nitrate and nitrite reductions with anaerobic sludge using various carbon sources: glucose, glycerol, acetic acid, lactic acid and methanol. Water Research, Vol.27 (8), pp. 1303-1312. 1993.

AMERICAN SOCIETY OF CIVIL ENGINEERS - ASCE. Standard: Measurement of Oxygen Transfer in Clean Water, ISBN 0-87262-430-7, New York, NY. 1991.

ANDREOTTOLA, G.; DAMIANI, E.; FOLADORI, P.; NARDELLI, P.; RAGAZZI, M.Treatment of mountain refuge wastewater by fixed a moving bed biofilm systems. Water Science and Technology, Vol 48 (11-12). pp. 169-177. $2003 b$.

ANDREOtTOlA, G.; FOlAdorI, P.; GATTI, G.; NARDELlI. P.; PETTENA, M.; RAGAZZI, M. Upgrading of a small overloaded activated sludge plant using a MBBR system.Journal of Environmental Science and Health, Part A: Toxic/Hazardous Substances Environmental Engineering. Vol 38 (10), pp. 2317-2328. $2003 a$.

ANDREOTTOLA, G.; FOLADORI, P.; RAGAZZI, M.; TATÀNO, F. Experimental comparison between MBBR and activated sludge sistem for the treatment of municipal wastewater. Water Science and Technology, Vol 41 (4-5). pp. 375-382. 2000.

APHA - AMERICAN PUBLIC HEALTH ASSOCIATION. Standard Methods for the Examination of Water and Wastewater. 22th. Washington: Public Health Association. 2012.

BARNARD J. L. Design of nitrification/denitrification process. Design for nitrogen removal and guarantees for aeration, Braunschweig. 1991. 
BASSIN, J.P., KLEEREBEZEM, R., MUYZER, G., ROSADO, A.S., VAN LOOSDRECHT, M.C.M. Effect of different salt adaptation strategies on the microbial diversity, activity, and settling of nitrifying sludge in sequencing batch reactors. Appl. Microb. Biotechnol. 93 (3), 1281-1294. 2012.

BORGHEI, S, M.; HOSSEINI, S, H. The treatment of phenolic wastewater using a moving bed biofilm reactor. Process Biochemistry, Vol 29, pp 1177-1181. 2004.

BROCH-DUE, A.; ANDERSEN, R.; OPHEIM, B. Treatment of integrated newsprint mill wastewater in moving bed biofilm reactors. Water Science and Technology. Vol 35 (2-3), pp. 173-180. 1997.

BROTTO, A. C. Fatores de Controle das Emissões de ÓxidoNitroso em Tanque de Aeração de Estação de Tratamento de Esgotos. Dissertação de Mestrado, Universidade Federal Fluminense, Brasil, 2011.

BROTTO, A. C.; KLIGERMAN, D. C.; PICCOLI, A. S.; DE MELLO, W. Z. Emissão de Óxido Nitroso de Estação de Tratamento de Esgotos de Lodos Ativados por Aeração Prolongada - Estudo Preliminar. Química Nova, 33, 2010.

BUENO, R. F. Nitrificação e desnitrificação simultânea em reator com biomassa em suspensão e fluxo contínuo de esgoto. 115p. Dissertação [Mestrado] - Faculdade de Saúde Pública da Universidade de São Paulo, São Paulo, 2011.

CALDERÓN, K.; MARTIN-PASCUAL, J.; POYATOS, J. M.; RODELAS, B.; GONZÁLEZMARTÍNEZ, A.; GONZÁLEZ-LÓPEZ, J.Comparative analysis of the bacterial diversity in a lab-scale moving bed biofilm reactor (MBBR) applied to treat urban wastewater under different operational conditions. Bioresour. Technol. 121, pp. 119-126. 2012.

CHEN, S.; SUN, D.; CHUNG, J. S. Simultaneous removal of COD and ammonium from landfill leachate using an anaerobic-aerobic moving-bed biofilm reactor system. Waste Manage. 28 (2) pp. 339-346. 2008.

CHEN, W. E.; RICHARD LIEW, J. Y.The Civil Engineering Handbook. $2^{\text {nd }}$ Ed. CRC Press LLC. Boca Raton, FL. 2904p. 2003. ISBN-13: 978-0849309588 
COSTA, A. M. Avaliação da influência da salinidade na nitrificação biológica. Dissertação de Mestrado. TPQB/EQ/UFRJ, Rio de Janeiro, RJ, Brasil. 2014.

COURA, M. A. Comportamento do sistema anaeróbio-aeróbio com reator anaeróbio de fluxo ascendente e manta de lodo e o sistema de lodo ativado no tratamento de esgoto doméstico na região tropical. Tese de Doutorado. 220 p. Campina GrandePB: UFCG. 2002.

CZEPIEL, P.; CRILL, P.; HARRISS, R. Nitrous Oxide Emissions from Municipal Wastewater Treatment.Environmental Science and Technology, 29 (9). 1995.

DAUDE, D.; STEPHENSON, T. Moving bed biofilm reactors: a small-scale treatment solution. Water Science and Technology, Vol 48 (11-12). pp. 251-257. 2003.

DEORSOLA, A. B. Influência dos cátions (sódio, potássio, cálcio e magnésio) no tratamento biológico de efluentes. Tese de Doutorado. PEQ/COPPE/UFRJ, Rio de Janeiro, RJ, Brasil. 2006.

DERKS, Y. M. Uso da respirometria para avaliar a influência de fatores operacionais e ambientais sobre a cinética de nitrificação. 100 f. Dissertação (Mestrado) Universidade Federal de Campina Grande, Campina Grande.2007.

DINÇER, A. R.; KARGI, F. Kinetics of Sequential Nitrification and Denitrification Processes. Enzyme and Microbial Technology, N. 27, pp 37-42. 2000.

FERRAI, M.; GUGLIELMI, G.; ANDREOTTOLA, G.Modelling respirometric tests for the assessment of kinetic and stoichiometric parameters on MBBR biofilm for municipal wastewater treatment. Environ Modell Softw. Vol. 25, pp 626-632. 2010.

FERREIRA, E. D. S. Aplicação da Respirometria na Caracterização de Esgoto Doméstico Afluente a uma ETE por Processo de Lodos Ativados. Dissertação de Mestrado em Tecnologia Ambiental e Recursos Hídricos. Departamento de Engenharia Civil e Ambiental da Universidade de Brasília, Brasil, 117p. 2002.

FIORUCCI, A.R.; SOARES, M.H.F.B. e CAVALHEIRO, E.T.G. O conceito de solução tampão.Química Nova na Escola. N. 13, p. 18-21, 2001. 
FOLEY, J.; DE HAAS, D.; YUAN Z.; P, LANT. Nitrous oxide generation in full-scale biological nutrient removal wastewater treatment plants. Water Research, 44 (3). 2010.

FU, B.; LIAO, X.Y.; DING, L.L.; REN, H.Q.Characterization of microbial community in an aerobic moving bed biofilm reactor applied for simultaneous nitrification and denitrification. World J. Microbiol. Biotechnol. 26, pp. 1981-1990. 2010.

HANAKI, K., WANTAWIN, C., OHGAKI, S. Effects of the activity of heterotrophs on nitrification in a suspended-growth reactor. Water Research, v. 24, pp. 289-296. 1990.

HEM, L, J; RUSTEN, B; ØDEGAARD, H. Nitrification in a Moving Bed Biofilm Reactor. Water Research. Vol 28 (6), pp. 1425-1433. 1994.

HENZE, M; HARREMOËS, P.; JANSEN, J. L. C.; ARVIN, E. Wastewater treatment. 2.ed. Germany, Springer. 1997.

HOLMAN, J. B.; WAREHAM, D.G.COD, ammonia and dissolved oxygen time profiles in the simultaneous nitrification/denitrification process.Biochemical Engineering Journal. 22, 125-133. 2005.

HONG-BIN, Y.; XIE, Q.; YUN-ZHENG, D. Medium-Strength Ammonium Removal Using a Two-Stage Moving Bed Biofilm Reactor System. Environmental Engineering Science. Vol 24 (05) pp 295-601. 2007.

IPCC - INTERGOVERNMENTAL PANEL ON CLIMATE CHANGE. Climate Change 2001: the Scientific Basis. Cambridge University Press. 2001.

IPCC - INTERGOVERNMENTAL PANEL ON CLIMATE CHANGE. Guidelines for National Greenhouse Gas Inventories - Chapter 6: Wastewater Treatment and Discharge. Vol. 5, Kanagawa, 2006.

IPCC, Intergovernmental Panel on Climate Change; IPCC. Guidelines for National Greenhouse Gas Inventories, Waste - Vol. 5, Kanagawa, 2006.

JAHREN, S, J.; RINTALA, J. A.; ØDEGAARD, H. Aerobic moving bed biofilm reactor treating thermomechanical pulping whitewater under thermophilic conditions. Water Research, Vol 36, pp 1067-1075. 2002. 
JONOUD, S.; VOSOUGHI, M.; KHALILI DAYLAMI, N.Study on nitrification and denitrification of high nitrogen and COD load wastewater in moving bed biofilm reactor. Iranian Journal of Biotechnology, Vol 1, (2), pp. 115-120. 2003.

JORDÃO, E. P.\& PESSÔA, C. A. Tratamento de Esgotos Domésticos. 7a ed. ABES-RJ, 1087p. 2014.

KAMPSCHREUR, M. J.; TEMMINK, H.; KLEEREBEZEM, R.; JETTEM, M. S. M.; VAN LOOSDRECHT, M. C. M. Nitrous oxide emission during wastewater treatment. Water Research. 43 (17). 2009.

KAMPSCHREUR, M. J.; VAN DER STAR, W. R. L.; WIELDERS, H. A.; MULDER, J. W.; JETTEN, M. S. M.; VAN LOOSDRECHT, M. C. M. Dynamics of nitric oxide and nitrous oxide emission during full-scale reject water treatment. Water Research. 42 (3). 2008.

KERMANI, M.; BINA, B.; MOVAHEDIAN, H.; AMIN, M. M.; NIKAEIN, M. Application of moving bed biofilm process for biological organics and nutrients removal from municipal wastewater. Am. J. Environ. Sci. 4, 675-682. 2008.

KIM, H.-S.; GELLNER, J. W.; BOLTZ, J. P.; FREUDENBERG, R. G.; GUNSCH, C. K.; SCHULER, A. J.Effects of integrated fixed film activated sludge media on activated sludge settling in biological nutrient removal systems. Water Res. 44, pp. 1553-1561. 2010.

KRICHTEN, D.; MCDOWELL, C. (n.y.): Simultaneous Nitrification and Denitrification in Biofilms of an Engineered Integrated Fixed-Film Activated Sludge (IFAS) System. Reading: Brentwood Industries, Inc. 2003.

LEYVA-DÍAZ, J. C.; CALDERÓN, K.; RODRÍGUEZ, F. A.; GONZÁLEZ-LÓPEZ, J.; HONTORIA, E.; POYATOS, J. M.Comparative kinetic study between moving bedbiofilm reactor membrane bioreactor and membrane bioreactor systems and their influence onorganic matter and nutrients removal. Biochem. Eng. J. 77, 28-40. 2013a

LEYVA-DÍAZ, J. C.; MARTÍN-PASCUAL, J.; GONZÁLEZ-LÓPEZ, J.; HONTORIA, E.; POYATOS, J. M. Effects of scale-up on a hybrid moving bed biofilm reactor - membrane bioreactor for treating urban wastewater. Chem. Eng. Sci. 104, 808-816. 2013b 
LOTITO, A. M.; WUNDERLIN, P.; JOSS, A.; KIPF, M.; SIEGRIST, H. Nitrous oxide emissions from the oxidation tank of a pilot activated sludge plant. Water Research. 46 (11). 2012

LUOSTARINEN, S.; LUSTE, S.; VALENTIN, L.; RINTALA, J. Nitrogen removal from on-site treated anaerobic effluents using intermittently aerated moving bed biofilm reactors at low temperatures. Water Research, Vol 40, pp 1607-1615. 2006.

MARTÍN-PASCUAL, J.; REBOLEIRO-RIVAS, P.; LÓPEZ-LÓPEZ, C.; LEYVA-DÍAZ, J.; JOVER, M.; MUÑIO, M.; GONZÁLEZ-LÓPEZ, J.; AND POYATOS, J. M. Effect of the Filling Ratio, MLSS, Hydraulic Retention Time, and Temperature on the Behavior of the Hybrid Biomass in a Hybrid Moving Bed Membrane Bioreactor Plant to Treat Urban Wastewater. J. Environ. Eng., 141 (7). 2015.

MARTÍN-PASCUAL, J.; REBOLEIRO-RIVAS, P.; LÓPEZ-LÓPEZ, C.; GONZÁLEZ-LÓPEZ, J.; HONTORIA, E., POYATOS, J. M.Influence of hydraulic retention time on heterotrophic biomass in a wastewater moving bed membrane and bioreactor treatment plant. Int. J. Environ. Sci. Technol. 11, 1449-1458. 2014.

MARTÍN-PASCUAL, J.; LÓPEZ-LÓPEZ, C.; CERDÁ, A.; GONZÁLEZ-LÓPEZ, J.; HONTORIA, E.; POYATOS, J. M.Comparative kinetic study of carrier type in a moving bed system applied to organic matter removal in urban wastewater treatment.Water, Air, Soil Pollut. 223(4), 1699-1712. 2012.

MCELROY, M. B. The Atmospheric Environment Effects of Human Activities. Princeton University Press: Princeton, 2002.

METCALF \& EDDY, Inc. Wastewater engineering: treatment and reuse. 4th ed. rev. New York: McGraw- Hill, 2003, 1848 p. ISBN 0-07-041878-0.

MINEGATTI, D. V. O. Carcacterização dos parâmetros de controle e avaliação de desempenho de um reator biológico com leito móvel (MBBR). 103p. Dissertação (Mestrado) - COPPE/UFRJ - Engenharia Civil, Universidade Federal do Rio de Janeiro, Rio de Janeiro, 2008.

MOUSSA, M.S.; SUMANASEKERA, D.U.; IBRAHIM, S.H.; LUBBERDING, H.J.; HOOIJMANS, C.M.; GIJZEN, H.J.; VAN LOOSDRECHT, M.C.M. Long term effects of salt on 
activity, population structure and floc characteristics in enriched bacterial cultures of nitrifies. Water Research, V. 40, p. 1377-1388, 2006.

MUNCH, E, V.; LANT, P.; KELLER, J.Simultaneous nitrification and denitrification in benchscale sequencing batch reactors. Water Research, Vol. 30 (2), pp. 277-284. 1996.

NBR 12209 - Projeto de Estações de Tratamento de Esgoto Sanitário. Associação Brasileira de Normas Técnicas. ABNT, 1990.

$\emptyset D E G A A R D, H .$, GISVOLD, B., STRICKLAND, J. The influence of size and shape in the moving bed biofilm process. Water Science and Technology, Vol. 41 (4-5), pp. 383-391. 2000.

ØDEGAARD, H; RUSTEN, B; WESTRUM, T. A new moving bed biofilm reactor - application and results. Water Science and Technology. Vol. 29 (10-11), pp. 157-165. 1994.

$\emptyset D E G A A R D, H ;$ RUSTEN, B; BADIN, H. Small wasterwater treatment plants based on moving bed biofilm reactor. Water Science and Technology. Vol. 28 (10), pp. 351359. 1993.

PASTORELLI, G; ANDREOTTOLA, G. Pilot-plant experimental with moving-bed biofilm reactors. Waste Science and Tecnhology. Vol. 36 (1) pp. 43-50. 1997.

PASTORELLI, G; ANDREOTTOLA, G; CANZIANI, R; DARRIULAT, C; FRAJA FRANGIPANE, E; ROZZI, A. Organic carbon and nitrogen removal in moving-bed biofilm reactors.Water Science and Tecnhology. Vol. 35 (6), pp. 91-99. 1997.

PLATTES, M.; HENRY, E.; SCHOSSELER, P. M.A zerodimensional biofilm model for dynamic simulation of moving bed bioreactor systems: model concepts, Peterson matrix, and application to a pilot-scale plant. Biochemical Engineering Journal, 40, 392-398. 2008.

PLATTES, M.; HENRY, E.; SCHOSSELER, P. M.; WEIDENHAUPT, A.Modelling and dynamic simulation of a moving bed bioreactor for the treatment of municipal wastewater. Biochem. Eng. J. 32(2), 61-68. 2006.

RAHIMI, Y.; TORABIAN, A.; MEHRDADI, N.; SHAHMORADI, B.Simultaneous nitrificationdenitrification and phosphorus removal in a fixed bed sequencing batch reactor (FBSBR). J. Hazard. Mater. 185, 852-857. 2011. 
RUSTEN, B.; EIKEBROKK, B.; ULGENES, Y.; LYGREN, E. Design and operations of the Kaldnes moving-bed biofilm reactors. Aquacultural Engineering, Vol 34 (3), pp. 322-331. 2006.

RUSTEN, B.; MCCOY, M.; PROCTOR, R.; SILUUDALEN, JON G. The innovative moving bed biofilm reactor/Solids contact reaeration process for secundary treatment of municipal wastewater. Water Environment Research, Vol 70 (5), pp. 1083-1089. 1998.

RUSTEN, B.; KOLKINN, O.; ØDEGAARD, H. Moving bed biofilm reactors and chemical precipitation for high efficiency treatment of wastewater from small communities. Water Science and Technology. 35 (6), pp. 71-79. 1997.

RUSTEN, B.; HEM, L.; ØDEGAARD, H. Nitrification of municipal wastewater in moving bed biofilm reactor. Water Environment Research, Vol 67 (1), pp 75-86. 1995.

RUSTEN, B.; HEM, L.; ØDEGAARD, H. Nitrogen removal from dilute wastewater in cold climate using moving bed biofilm reactor. Water Environment Research, Vol 67 (1), pp. 65-74. 1995.

RUSTEN, B.; SILUUDALEN, J, G.; NORDEIDET, B.Upgrading to nitrogen removal with the KMT moving bed biofilm process. Water Science and Tecnhology, Vol 29 (12), pp. 185-195. $1994 a$.

RUSTEN, B.; MATTSSON, E.; BROCH-DUE, A.; WESTRUM, T. Treatment of pulp and paper industry wastewater in novel moving bed biofilm reactors. Water Science and Tecnhology, Vol 30 (3), pp. 161-171. 1994b.

SALVETTI, R.; AZZELLINO, A.; CANZIANI, R.; BONOMO, L.Effects of temperature on tertiary nitrification in moving-bed biofilm reactors. Water Res. 40 (15), 2981-2993. 2006.

SCHMIDT, I.; SLIEKERS, O.; SCHMID, M.; BOCK, E.; FUERST, J.; KUENEN, J.; JETTEN, M.; STROUS, M. New Concepts of Microbial Treatment Process for the Nitrogen Removal in Wastewater. FEMS Microbiology Reviews, N. 27, pp 481-492. 2003.

SRIWIRIYARAT, T.; RANDALL, C. W. Performance of IFAS wastewater treatment processes for biological phosphorus removal.Water Res., 39(16), 3873-3884. 2005. 
SURAMPALLI, R. Y.; TYAGI, R. D.; SCHEIBLE, O. K.; HEIDMAN, J. A. Nitrification, denitrification and phosphorus removal in sequential batch reactors. Bioresource Technology, v. 61, p. 151-157. 1997.

TALLEC, G.; GARNIER, J.; BILLEN, G.; GOUSAILLES, M. Nitrous oxide emissions from denitrifying activated sludge of urban wastewater treatment plants, under anoxia and low oxygenation. Bioresource Technology 99 (7). 2008.

TALLEC, G.; GARNIER, J.; BILLEN, G.; GOUSAILLES, M. Nitrous oxide emissions from secondary activated sludge in nitrifying conditions of urban wastewater treatment plants: effect of oxygenation level. Water Research 40 (15). 2006.

THAURÉ, D.; LEMOINE, C.; DANIEL, O.; MOATAMRI, N.; CHABROL, J. Optimisation of aeration for activated sludge treatment with simultaneous nitrification denitrification. Water Sci Technol, vol.58(3), 639-645, 2008.

TRAPANI, D. D.; MANNINA, G.; TORREGROSSA, M.; VIVIANI, G. Quantification of kinetic parameters for heterotrophic bacteria via respirometry in a hybrid reactor. Water Sci. Technol., 61(7), 1757-1766. 2010.

U.S. EPA, United States Environmental Protection Agency; Inventory of U.S. Greenhouse Gas Emissions and Sinks: 1990-2009, Washington, 2011.

VAN HAANDEL, A, C.; CATUNDA, P. F. C. Determinação da taxa de consumo de oxigênio em sistemas de tratamento de esgotos. Engenharia Sanitária, Vol. 21 (4), pp. 481788. 1982.

VAN HAANDEL, A. C.; MARAIS, G. V. R. O Comportamento do Sistema de Lodo Ativado: Teoria e Aplicações para Projetos e Operações. Campina Grande: epgraf, 472 p., 1999.

VON SPERLING, M. Princípios do Tratamento Biológico de Águas Residuárias. Introdução à Qualidade das Águas e ao Tratamento de Esgotos, 3a Ed. Vol 1, Departamento de Engenharia Sanitária e Ambiental - UFMG. 452p. 2005.

VON SPERLING, M. Princípios do Tratamento Biológico de Águas Residuárias. Lodos ativados. Vol 4. Departamento de Engenharia Sanitária e Ambiental - UFMG. 428p. 1997. 
VON SPERLING, M. Princípios do Tratamento Biológico de Águas Residuárias. Princípios Básicos do Tratamento de Esgotos, 2a Ed. Vol 2. Departamento de Engenharia Sanitária e Ambiental - UFMG. 211p. 1996.

WANDERLEY, E. L.; SIQUEIRA, J. P. S.; CALLADO, N. H. Interferência da salinidade na remoção biológica aerobia de matéria orgânica. XX Simpósio Brasileiro de Recursos Hídricos, Bento Gonçalves - RS. 2013.

WANG, X, J; XIA, S, Q; CHEN, L; ZHAO, J, F; RENAULT, N, J; CHOVELON, J, M. Nutrients removal from municipal wastewater by chemical precipitation in a moving bed biofilm reactor. Process Biochemistry, Vol 41, pp. 824-828. 2006.

XING, X.H., JUN, B.M., YANAGIDA, M., TANJI, Y., UNNO, H.Effect of $\mathbf{C} / \mathbf{N}$ values on microbial simultaneous removal of carbonaceous and nitrogenous substances in wastewater by single continuos-flow fluidized-bed bioreactor containing porous carrier particles. Biochemical Engineering Journal. Vol 5, pp. 29-37. 2000.

ZHANG, S.; WANG, Y.; HE, W.; XING, M.; WU, M.; YANG, J.; GAO, N.; SHENG, G.; YIN, D.; LIU, S. Linking nitrifying biofilm characteristics and nitrification performance in moving-bed biofilm reactors for polluted raw water pretreatment. Bioresource Technology. 146, 416-425. 2013.

ZHANG, P.; ZHOU QI. Simultaneous nitrification and denitrification in activated sludge system under low oxygen concentration. Front. Environ. Sci. Engin. China 1(1), pp 49-52. 2007.

ZHU, G. B.; Peng, Y. Z.; WU, Shu-yun.; WANG, Shu-ying.; XU, Shi-we. Simultaneous nitrification and denitrification in step feeding biological nitrogen removal process. Journal of Environmental Sciences. Vol 19, pp 1043-1048. 2007. 